FACULDADE DE ECONOMIA, ADMINISTRAÇÃO E CONTABILIDADE

DEPARTAMENTO DE ADMINISTRAÇÃO

PROGRAMA DE PÓS-GRADUAÇÃO EM ADMINISTRAÇÃO

CURSO DE DOUTORADO

\title{
ESTRATÉgias CORPorativas PARA A SUSTENTABILIDADE: Estudos de Casos Múltiplos
}

\author{
Tese de Doutorado
}

Annelise Vendramini S. Caridade

Orientador: Prof. Dr. Isak Kruglianskas

\author{
Versão Corrigida \\ (Versão original disponível na Faculdade de Economia, Administração e Contabilidade)
}

SÃO PAULO 
Prof. Dr. João Grandino Rodas Reitor da Universidade de São Paulo

Prof. Dr. Reinaldo Guerreiro

Diretor da Faculdade de Economia, Administração e Contabilidade

Prof. Dr. Adalberto Américo Fischmann

Chefe do Departamento de Administração

Prof. Dr. Lindolfo Galvão de Albuquerque

Coordenador do Programa de Pós Graduação em Administração 
Annelise Vendramini da Silva Caridade

\section{ESTRATÉgias CORPORATIVAS PARA A SUSTENTABILIDADE: ESTUdOS DE CASOS Múltiplos}

Tese apresentada ao Departamento de Administração da Faculdade de Economia, Administração e Contabilidade da Universidade de São Paulo como um dos requisitos para a obtenção do título de Doutor em Ciências.

Orientador: Professor Dr. Isak Kruglianskas

Versão Corrigida

(versão original disponível na Faculdade de Economia, Administração e Contabilidade)

São Paulo 
FICHA CATALOGRÁFICA

Elaborada pela Seção de Processamento Técnico do SBD/FEA/USP

Caridade, Annelise Vendramini da Silva

Estratégias corporativas para a sustentabilidade: estudos de casos múltiplos / Annelise Vendramini da Silva Caridade. - São Paulo, 2012. $179 \mathrm{p}$.

Tese (Doutorado) - Universidade de São Paulo, 2012.

Orientador: Isak Kruglianskas.

1. Estratégia organizacional 2. Sustentabilidade 3. Meio ambiente I. Universidade de São Paulo. Faculdade de Economia, Administração e Contabilidade II. Título.

CDD -658.401 
Nenhum empreendimento, ainda que singelo, seria concretizado sem a contribuição de muitos. Minha mais profunda gratidão a todos que direta e indiretamente contribuíram para este projeto.

$* * *$

Em particular, gostaria de expressar meus mais sinceros agradecimentos:

À minha família; ao meu orientador, Prof. Dr. Isak Kruglianskas; ao Professor João Furtado, meu amigo e mestre; à minha amiga Mayuli e ao Alexandre Igari; à Universidade de São Paulo e à FEA; a CAPES pelo apoio financeiro ao longo do Doutorado e do Mestrado; à Márcia e Vanessa pelo apoio em absolutamente tudo; à Professora Dra Clândia Maffini Gomes; à Banca de Qualificação, composta pelos Professores Dr. Hermann Hrdlicka, Dr. Roy Martelanc e Dr. Isak Kruglianskas; ao Jorge Soto; aos Professores Dr. Adalberto Fischmann, Dr. Danilo Igliori; aos meus amigos Flávio Hourneaux Jr e André Felix Cardoso; às empresas que aceitaram participar desta pesquisa; à Secretaria da Pós-Graduação (e um especial agradecimento à Cida).

E um muito obrigada aos participantes de meus cursos que, debatendo comigo as ideias aqui apresentadas, contribuíram imensamente para o meu trabalho. 
"Here the ways of men divide. If you want to achieve peace of mind and happiness, then have faith; if you want to be a disciple of truth, then search."

Friedrich Nietzche "Selected Letters of Friedrich Nietzche", p.7

"You act like mortals in all that you fear and like immortals in all that you desire."

Sêneca

"On the Shortness of Life", p. 5 


\section{RESUMO}

Este estudo procura contribuir com as discussões sobre gestão estratégica corporativa para a sustentabilidade, procurando responder ao seguinte problema de pesquisa: "Como se dá a inclusão, nas estratégias corporativas para a sustentabilidade, das externalidades ambientais negativas geradas pela cadeia de valor em que a organização está inserida?" São objetivos deste trabalho: (i) analisar de que forma as organizações pesquisadas consideram, no processo de formulação de suas estratégias, o diagnóstico de suas externalidades negativas ambientais para também fazer gestão de risco estratégico socioambiental e aproveitar eventuais oportunidades; (ii) analisar como o processo de formulação de estratégias para a sustentabilidade dialoga com o processo de formulação estratégica geral das organizações pesquisadas; (iii) contribuir para o avanço do conhecimento da Administração no campo da gestão estratégica para a sustentabilidade, particularmente do ponto de vista da argumentação econômica teórica do tema da sustentabilidade. O referencial teórico consiste dos seguintes macro temas: estratégia corporativa, desenvolvimento sustentável, externalidades e estratégia corporativa para a sustentabilidade. O referencial teórico orientou a realização de uma pesquisa empírica, de natureza qualitativa, exploratória, do tipo estudos de casos múltiplos, envolvendo três grandes empresas brasileiras. Os resultados da pesquisa apontam para a observância, pelas empresas pesquisadas, com distintos níveis de formalização do processo, das externalidades ambientais negativas geradas por suas cadeias de valor. Consistente com a natureza dos estudos exploratórios, com base no referencial teórico e nos casos empíricos estudados, são feitas reflexões sobre as relações entre estratégias corporativas, estratégias para sustentabilidade, externalidades, serviços ecossistêmicos, riscos e oportunidades para as organizações. 


\begin{abstract}
In order to contribute to the contemporary discussions regarding corporate sustainability strategies, this research seeks to answer the following question: "In what ways are the negative environmental externalities generated by a company's value chain considered in the sustainability corporate strategies?" This research aims at: (i) understanding how organizations that are sustainability-oriented take into consideration in their sustainability strategy making process the diagnosis of their value chain's negative environmental externalities as to manage risks and create business opportunities; (ii) understanding the links between the sustainability strategy and the company's overall strategy; (iii) contributing to the body of knowledge in Management Sciences, particularly by making the economic argument for sustainability strategy. The theoretical basis includes: corporate strategy, sustainable development, externalities and sustainability corporate strategies. The theoretical basis guided the empirical research, which is qualitative, exploratory, multiple case study, involving three large Brazilian companies. Results point out to the consideration in their sustainability strategies - with different adherence and formalization levels - of the negative environmental externalities generated by their value chain. Consistent with exploratory studies, and based on the literature review and the cases studied, considerations are made regarding the relationships among corporate strategies, sustainability corporate strategies, externalities, ecosystem services, business risks and opportunities.
\end{abstract}




\section{SUMÁRIO}

$\begin{array}{lr}\text { Lista de Quadros } & 05\end{array}$

Lista de Tabelas $\quad 05$

$\begin{array}{ll}\text { Lista de Figuras } & 05\end{array}$

Lista de Boxes

Lista de Gráficos $\quad 06$

$\begin{array}{ll}\text { Capítulo 1. Introdução } & 07\end{array}$

$\begin{array}{ll}1.1 \text { Apresentação } & 07\end{array}$

$\begin{array}{ll}1.2 \text { Definição do problema de pesquisa } & 09\end{array}$

$\begin{array}{ll}1.3 \text { Objetivo geral } & 09\end{array}$

$\begin{array}{ll}1.4 \text { Objetivos específicos } & 10\end{array}$

$\begin{array}{ll}1.5 \text { Pressupostos conceituais } & 10\end{array}$

$\begin{array}{ll}1.6 \text { Justificativa } & 11\end{array}$

$\begin{array}{ll}1.7 \text { Definições de conceitos relevantes } & 13\end{array}$

Capítulo 2. Fundamentação teórica $\quad \mathbf{1 5}$

2.1 Introdução: a estratégia corporativa 16

2.2 Desenvolvimento sustentável 24

2.3 Externalidades $\quad 29$

2.3.1 Soluções para o problema de externalidades negativas $\quad 39$

2.3.2 Serviços Ecossistêmicos 41

2.3.2.1 Pagamentos por Serviços Ambientais $\quad 54$

2.3.2.2 Mercados de Carbono 56

2.4 A sustentabilidade no nível da firma: a formulação da estratégia corporativa $\quad 63$

$\begin{array}{ll}2.5 \text { Considerações sobre o referencial teórico } & 79\end{array}$

$\begin{array}{lr}\text { Capítulo 3. Metodologia de pesquisa } & 81\end{array}$

$\begin{array}{ll}3.1 \text { Método e tipo de pesquisa } & 81\end{array}$

3.2 Modelo conceitual $\quad 84$

3.3 Seleção dos casos $\quad 88$

3.4 Instrumentos de pesquisa $\quad 89$

$\begin{array}{ll}3.5 \text { Limitações do método } & 90\end{array}$

Capítulo 4. Análise dos resultados $\quad 91$

4.1 Estudo de caso: a empresa "Mario Quintana" $\quad 92$

4.1.1 Contexto da empresa $\quad 92$

4.1.2 Missão e valores $\quad 94$

4.1.3 Estratégia para a sustentabilidade 94

4.1.4 O processo de formulação das estratégias para a sustentabilidade e o diálogo com a formulação das demais estratégias $\quad 99$

4.1.5 Reflexões e interpretações dos dados levantados 102

4.2 Estudo de caso: a empresa "Cecília Meireles" 108

4.2.1 Contexto da empresa 108

$\begin{array}{ll}4.2 .2 \text { Visão e valores } & 109\end{array}$

$\begin{array}{ll}\text { 4.2.3 Estratégia para a sustentabilidade } & 110\end{array}$ 
4.2.4 O processo de formulação das estratégias para a sustentabilidade e o diálogo com a formulação das demais estratégias 111

4.2.5 Reflexões e interpretações dos dados levantados 116

4.3 Estudo de caso: o conglomerado financeiro

"Carlos Drummond de Andrade" 123

$\begin{array}{ll}\text { 4.3.1 Contexto da empresa } & 123\end{array}$

4.3.2 Missão e valores $\quad 124$

4.3.3 Estratégia para a sustentabilidade $\quad 124$

4.3.4 O processo de formulação das estratégias para a sustentabilidade e o diálogo com a formulação das demais estratégias 129

4.3.5 Reflexões e interpretações dos dados levantados $\quad 132$

4.4 Análise comparativa dos casos 135

$\begin{array}{lr}\text { Capítulo 5. Considerações Finais } & 145\end{array}$

$\begin{array}{lr}\text { Capítulo 6. Bibliografia } & 149\end{array}$

Apêndice I - Protocolo de estudo de caso 161

Apêndice II - Definições de conceitos relevantes 162

Apêndice III - O Global Reporting Initiative (GRI) 165 


\section{Lista de Abreviaturas}

ABIQUIM - Associação Brasileira da Indústria Química

CCX - Chicago Climate Exchange

CDA - Carlos Drummond de Andrade (pseudônimo para empresa pesquisada)

CDM - Clean Development Mechanism

CEO - Chief Executive Officer

CER - Certified Emissions Reductions

CERES - Coalition for Environmentally Responsible Economies

CM - Cecília Meireles (pseudônimo para empresa pesquisada)

$\mathrm{CO}_{2}$ - dióxido de carbono

$\mathrm{CO}_{2} \mathrm{e}$ - dióxido de carbono equivalente

CPR - Common-Pool Resources

EBITDA - Earnings Before Interest, Taxes, Depreciation and Amortization

ESR - Ecosystem Services Review

EU ETS - European Emission Trade System

FEBRABAN - Federação Brasileira de Bancos

FCS - Fatores Críticos de Sucesso

GEE - Gases de Efeito Estufa

GIS - Geographical Information Systems

GISc - Geographical Information Science

GRI - Global Reporting Initiative

IBAMA - Instituto Brasileiro do Meio Ambiente e dos Recursos Naturais Renováveis

IBGE - Instituto Brasileiro de Geografia e Estatística

ICCA - International Council of Chemical Associations

JI- Joint Implementation

MEA - Millennium Ecosystem Assessment

MPFPA - Ministério Público Federal no Pará

MQ - Mário Quintana (pseudônimo para empresa pesquisada)

ONG - Organização Não Governamental

ONU - Organização das Nações Unidas

PNUMA - Programa das Nações Unidas para o Meio Ambiente

PSA - Pagamento por Serviços Ambientai 
REACH - Registration, Evaluation, Authorisation and Restriction of Chemical Substances

RSA - Responsabilidade Social e Ambiental

RSE - Responsabilidade Social Empresarial

RGGI - Regional Greenhouse Gas Initiative

SSMA - Saúde, Segurança e Meio-Ambiente

SWOT - Strengths, Weaknesses, Opportunities and Threats

TEEB - The Economics of Ecosystems and Biodiversity

UNEP - United Nations Environmental Programme

VER - Voluntary Emission Reductions

WBCD - World Business Council for Sustainable Development

WRI - World Resources Institute 


\section{Lista de Quadros, Tabelas, Figuras, Boxes e Gráficos}

\section{Quadros}

Quadro 1: Alguns tipos de externalidades 33

Quadro 2: Tipologia e exemplos de serviços ecossistêmicos 39

Quadro 3: Potenciais fontes de riscos e oportunidades oriundos de $\begin{array}{ll}\text { serviços ecossistêmicos } & 47\end{array}$

Quadro 4: Características dos mercados cap-and-trade e de offsets 57

Quadro 5: Condições sistêmicas da sustentabilidade se traduzem em impactos e ações dentro das organizações $\quad 65$

Quadro 6: Subprodutos negativos das atividades empresariais privadas $\quad 74$

Quadro 7: Síntese das características das empresas pesquisadas 134

Quadro 8: Síntese dos aspectos bibliográficos observados na análise dos casos $\quad 140$

Quadro 9: Síntese dos princípios e da divulgação padrão, segundo as 166 diretrizes GRI

\section{Tabelas}

Tabela 1: Volumes de carbono e montantes negociados nos mercados de carbono, em 2008 e 2009

Tabela 2: Informações financeiras selecionadas do Grupo ao qual pertence a holding "Mario Quintana" 91

Tabela 3: Informações financeiras selecionadas da empresa “Cecília Meireles” 107

Tabela 4: Informações financeiras selecionadas do conglomerado

"Carlos Drummond de Andrade" 122

$\begin{array}{ll}\text { Tabela 5: Países/regiões das empresas relatoras, por ano } & 164\end{array}$

\section{Figuras}

Figura 1: Visão geral da revisão bibliográfica $\quad 13$

$\begin{array}{ll}\text { Figura 2: O processo de gestão estratégica } & 16\end{array}$

Figura 3: Tipologia de riscos segundo Andersen e Schroder (2010) 21

Figura 4: A presença da externalidade 31

Figura 5: Classificação geral de tipos de bens $\quad 34$

Figura 6: Esquema relacionando serviços ecossistêmicos e processos decisórios 42

Figura 7: Framework para consideração dos serviços ecossistêmicos na 
estratégia corporativa

Figura 8: Perguntas orientadoras para avaliar dependência

dos serviços ecossistêmicos pela organização

Figura 9: Perguntas orientadoras para avaliar impacto da organização

sobre os serviços ecossistêmicos

Figura 10: Mapeando a interdependência entre negócios e sociedade: impacto social da cadeia de valor (Inside-Out)

Figura 11: Mapeando a interdependência entre negócios e sociedade: impacto social sobre a competitividade (Outside-In)

Figura 12: Framework relacionando a estratégia corporativa,

a estratégia para a sustentabilidade e o desempenho financeiro de longo-prazo

Figura 13: Método de replicação dos estudos de casos múltiplos

Figura 14: Modelo conceitual de pesquisa

Figura 15: Modelo conceitual para o diagnóstico de impactos e demandas sobre os serviços ecossistêmicos, riscos e oportunidades para a estratégia corporativa

Figura 16: Estrutura da ferramenta de avaliação de impactos

socioambientais nos processos de investimento em desenvolvimento pela "MQ" 99

Figura 17: Fluxo simplificado do processo de formulação de

estratégias de sustentabilidade na "MQ"

Figura 18: Análise da relevância dos aspectos socioambientais selecionados com base no GRI

Figura 19: Fluxo simplificado do processo de formulação estratégica

para sustentabilidade da empresa "CM"

Figura 20: Fluxo simplificado do processo de formulação

estratégica para sustentabilidade do banco empresa "CDA"

\section{Boxes}

Box 1: Compromissos externos voluntários - caso "Mario Quintana"

Box 2: Compromissos externos voluntários - caso "Cecília Meireles"

Box 3: Compromissos externos voluntários - caso

"Carlos Drummond de Andrade"

\section{Gráficos}

Gráfico 1: Número total de organizações que adotam o padrão GRI para reporte da sustentabilidade, por ano. 


\section{Capítulo 1: Introdução}

\subsection{Apresentação}

Desde que se tornaram públicos e frequentes os estudos sobre o impacto da produção e do consumo humanos sobre os ecossistemas terrestres, raramente se lê um jornal sem uma nova notícia de grave ameaça ambiental. As dúvidas recaem não mais sobre a essência do problema - que parece já ser bastante conhecida: a pressão humana excessiva sobre os recursos naturais -, mas sobre as formas de resolvê-lo. A questão ganha complexidade quando se trata de recursos naturais cujos benefícios são usufruídos por muitos indivíduos em comum. Os desafios socioambientais atuais - tais como mudanças climáticas, poluição severa do ar, acesso à água potável, extinção da biodiversidade marinha, aquática e terrestre, entre outros tratam em sua essência de recursos compartilhados por muitos, de uso comum, ou os chamados commons. A teoria que trata do termo tem como marco relevante o artigo de Garrett Hardin (1968) sobre a tragédia dos comuns em que a racionalidade da escolha individual resulta em colapso coletivo (ou irracionalidade coletiva).

Commons é um termo genérico para recursos compartilhados em que cada stakeholder tem um interesse igual. Entre os temas que compõem os chamados global commons estão chuva ácida, poluição do ar, atmosfera, seqüestro de carbono, mudanças climáticas, governança e gestão das regiões polares, aquecimento global, gases de efeito estufa, tratados internacionais, oceanos, espaço sideral, governança, lei e gestão de recursos e disputas trans-fronteiriços, entre outros (Ostrom et al, 1999).

É indiscutível que o caminho para a solução destes desafios passa pela ação coletiva. Ação coletiva tem suas bases na teoria de comportamento de grupos; ação coletiva é quando indivíduos com interesses comuns agem de maneira voluntária de forma a alcançar estes interesses (OLSON, 2002). Esforços de ação coletiva para gestão de commons precisam considerar o envolvimento do setor produtivo e do setor financeiro em razão dos relevantes impactos políticos, econômicos, sociais, culturais e ambientais que geram ou induzem no mundo contemporâneo. 
Os desafios socioambientais atuais têm natureza sistêmica e os caminhos para as soluções destes desafios passam, necessariamente, pela cooperação entre as empresas, sociedade civil e Estado. Sem o comprometimento das empresas com as causas que envolvem os recursos de uso comum, muito pouco avançará na proteção e gestão destes recursos.

Mas por que empresas se engajariam em esforços para a sustentabilidade?

O objetivo imediato das organizações pode ser a maximização do lucro, mas o objetivo último é a sobrevivência porque as organizações vivem em um mundo de escassez e, portanto, de competição (NORTH, 2008). As estratégias organizacionais são também altamente influenciadas por mudanças institucionais, já que instituições influenciam resultados tanto em nível individual como em nível coletivo (HoffMan, 2001; Peng, 2006; Peng, W ANG E JiAng, 2008). Instituições são as regras escritas e não escritas, normas, restrições que os seres humanos criam para reduzir a incerteza e controlar o ambiente em que vivem. Nestas estão incluídos (i) as regras e acordos escritos que regulam relações contratuais e governança corporativa; (ii) constituições, leis e regras que governam políticas, governo, finanças e sociedade em um senso mais amplo; e (iii) códigos de conduta, normas de comportamento e crenças não escritos (NORTH 1991; Williamson, 2000, apud MÉNARD, 2005). Há uma diferença entre instituições e organizações: instituições são as regras que definem como um jogo deve ser jogado; organizações são os jogadores. Organizações são as firmas, sindicatos, cooperativas etc (NORTH, 2008)

As discussões sobre o papel das empresas privadas no sentido de contribuir para o desenvolvimento sustentável espelham mudanças no ambiente institucional. Embora tais mudanças sejam difíceis de serem monitoradas pelos gestores das empresas envolvidos com o cotidiano de suas atividades, têm grande influência sobre os rumos de longo-prazo do ambiente de negócios.

É uma premissa desta pesquisa que as organizações alinhadas com o tema da sustentabilidade estejam procurando adaptar seus processos de gestão às mudanças em andamento no ambiente institucional. E estão se preparando, em maior ou menor grau, para serem competitivas no futuro. Futuro que, embora desconhecido, terá, acredita-se, a sustentabilidade como condição sine qua non para existência de uma empresa (outra premissa). Justamente por isso, a 
construção de uma argumentação estratégica para a sustentabilidade amparada em princípios econômicos, o chamado "business case", é um desafio para os gestores de empresas de hoje, afinal, são inúmeros os casos de empresas bem-sucedidas do ponto de vista econômicofinanceiro que não se posicionam como empresas que buscam a sustentabilidade. Considerando este paradoxo, esta pesquisa procura nos fundamentos econômicos selecionados, a contribuição conceitual para que os gestores de empresas comprometidas com a sustentabilidade possam pavimentar seus caminhos rumo a um futuro menos insustentável.

Os fundamentos econômicos das externalidades contribuem para as teorias estratégicas da sustentabilidade. Faz sentido para as empresas privadas conhecerem e monitorarem os custos externos (externalidades negativas) que suas atividades impõem à sociedade e considerá-los como objetos prioritários de suas estratégias para a sustentabilidade. Porque a teoria nos mostra que estes custos serão objeto de atenção da sociedade, no sentido da internalização nos custos marginais privados, de forma total ou parcial.

\subsection{Definição do problema de pesquisa}

A pergunta que se pretende responder com esta pesquisa é:

"Como se dá a inserção, nas estratégias corporativas para a sustentabilidade, das externalidades ambientais negativas geradas por sua cadeia de valor?"

\subsection{Objetivo geral}

Este estudo tem como objetivo geral compreender como se dá a inserção, nas estratégias corporativas para a sustentabilidade, das externalidades ambientais negativas geradas pela cadeia de valor em que a organização está inserida, desta forma contribuindo para o avanço da Administração neste campo.

A principal contribuição da teoria das externalidades para a formulação das estratégias corporativas para a sustentabilidade é o entendimento de que eventuais custos externos impostos pelas atividades corporativas a terceiros serão alvo de medidas para sua correção. Neste sentido, a teoria das externalidades serve como teoria orientadora para o processo de 
formulação de estratégias para sustentabilidade tendo em vista a competitividade organizacional.

\subsection{Objetivos específicos}

Os objetivos específicos desta tese são:

1) Analisar de que forma as externalidades negativas ambientais são consideradas nas estratégias para a sustentabilidade;

2) Analisar como o processo de formulação de estratégias para a sustentabilidade dialoga com o processo de formulação estratégica geral;

3) Contribuir para o avanço do conhecimento de administração no campo da gestão estratégica para a sustentabilidade, particularmente do ponto de vista da argumentação teórica econômica do tema da sustentabilidade;

4) Apresentar recomendações para executivos atuantes na área de gestão estratégica para a sustentabilidade, visando contribuir para maior competitividade empresarial.

\subsection{Pressupostos conceituais}

É um pressuposto deste estudo que as organizações que tenham por intento estratégico a sustentabilidade (no âmbito dos conceitos ligados ao desenvolvimento sustentável), o fazem porque estão se adaptando a mudanças no ambiente institucional. Assim, uma premissa decorrente desta, é que só se manterão competitivas no futuro empresas que contribuam para o desenvolvimento sustentável.

Outro pressuposto conceitual sobre o qual se discute gestão organizacional e estratégias para a sustentabilidade nesta tese é o de que o papel dos gestores é agir no melhor interesse dos acionistas, tomando decisões que assegurem seu retorno (TIROLE, 2006). O Value-Based Management (MARTIN et al, 2009) estabelece que o fim último da gestão organizacional é maximizar o valor econômico de longo-prazo da firma, e, portanto, da riqueza do acionista. Embora outros quadros teóricos sejam possíveis, optou-se por discutir estratégias para a sustentabilidade a partir deste pressuposto conceitual. 


\subsection{Justificativa}

As pesquisas na área de gestão normalmente têm natureza multidisciplinar e tendem a ter como requisito a aplicação prática da pesquisa, o que significa que precisam conter algum potencial para tomada de ação ou considerar os aspectos práticos das conclusões e análises resultantes das pesquisas; as pesquisas em gestão precisam conectar o mundo da teoria com o mundo da prática. Assim, contribuem para o avanço teórico e para o entendimento de questões ligadas ao mundo da gestão, mas também buscam resolver problemas práticos de gestão. Têm por missão desenvolver conhecimento válido que apóie e esclareça a solução de problemas práticos no campo. Este suporte pode ser direto, instrumental ou indireto (SAUNDERS, LEWIS, THORNHILL, 2009).

A carência de um conhecimento mais sistematizado que contribua para a fundamentação econômica das estratégias para a sustentabilidade e que possam amparar os formuladores de estratégias corporativas para a sustentabilidade com argumentos de natureza econômica fortalece a oportunidade para a realização deste estudo.

\subsubsection{Motivações para a realização desta pesquisa ${ }^{1}$}

Neste tópico são apresentadas as motivações da autora para a realização desta pesquisa. Como pesquisadora, docente, consultora e gestora em Administração e, particularmente, em Gestão para a Sustentabilidade desde o ano 2000, pude acompanhar, ao longo dos anos, muitas reuniões de Conselho de Administração onde acontecem os debates estratégicos sobre tomadas de decisão relacionadas às estratégias para a sustentabilidade. E, neste sentido, participei ativamente dos dilemas envolvidos nestes processos e que, frequentemente, opõem entusiastas do tema da sustentabilidade (geralmente os gestores de sustentabilidade) e os guardiões dos resultados econômico-financeiros das organizações. Parece-me razoável supor que nestes dilemas os segundos têm tido mais sucesso que os primeiros, pois se assim não fosse, estaríamos mais próximos de viver em um mundo menos insustentável. Minha experiência como docente em cursos de pós-graduação lato sensu, com participantes que ocupam níveis hierárquicos de liderança em empresas, também corrobora a ideia de que há

\footnotetext{
${ }^{1}$ Neste tópico faz-se uso da primeira pessoa do singular porque apresenta as motivações da autora deste trabalho. Posteriormente, retoma-se a terceira pessoa do singular.
} 
uma grande dificuldade em aproximar o mundo da sustentabilidade do mundo dos negócios em processos decisórios mais complexos.

Mas por que isso acontece? Entre outros aspectos, com muita frequência (na verdade é quase a norma), os gestores de sustentabilidade encontram dificuldades em encontrar argumentos que os ajudem na defesa das estratégias de sustentabilidade em termos que ressaltem o valor que as estratégias de sustentabilidade geram para os negócios da organização. Provavelmente isso acontece porque a valoração das iniciativas de sustentabilidade ainda permanece como um desafio para pesquisadores e praticantes no tema. Assim, embora as teorias de sustentabilidade afirmem que as estratégias de sustentabilidade geram valor para as organizações, os instrumentos de gestão que podem contribuir para a explicitação deste valor são ainda escassos na literatura sobre o tema e também na prática cotidiana das organizações. As salas de Conselho são, em geral, ambientes onde ainda predominam decisões que tenham sido fundamentadas na geração de valor.

Em minhas atividades profissionais na área de sustentabilidade e como docente notei que embora o Triple Bottom Line seja um conceito fundamental para a gestão da sustentabilidade, há uma carência de instrumentos de gestão à disposição dos gestores para que façam a gestão efetiva baseada no Triple Bottom Line. Deparei-me também com questões como:

- "Todas as organizações, todos os negócios, deveriam dar igual atenção às três dimensões da gestão para sustentabilidade: econômica, social e ambiental? Um banco e uma indústria química, por exemplo, deveriam gerir as três dimensões da mesma maneira?";

- "Uma mesa organização, ao longo do tempo, atribuirá sempre o mesmo peso para as dimensões econômica, social e ambiental? Ou isso pode mudar dependendo de seu impacto e sua estratégia?";

Esta tese foi motivada por estas reflexões e por uma questão de fundo que é contribuir para diminuir as lacunas entre o pensar a sustentabilidade e o desenvolvimento sustentável (ou seja, considerando o avanço nas teorias sobre estes temas, em particular a partir das décadas de 1960 e 1970) e as práticas de gestão (onde a questão do valor é predominante). 
Assim sendo, a principal motivação desta pesquisa foi oferecer contribuições para os arrazoados estratégicos dos gestores da área de sustentabilidade.

\subsection{Definições de conceitos relevantes}

No apêndice II são apresentadas as definições teóricas dos conceitos relevantes adotadas ao longo deste estudo. 


\section{Capítulo 2: Fundamentação Teórica}

Este capítulo apresenta os conceitos fundamentais para a realização deste estudo. Em primeiro lugar, é apresentada uma breve introdução sobre os conceitos relativos à estratégia corporativa. Saindo do mundo da estratégia corporativa "tradicional", o leitor entrará no mundo da sustentabilidade. Portanto, na sequência, são apresentados os conceitos relativos ao desenvolvimento sustentável. Isto para que o leitor compreenda os principais conceitos em nível macro que impactarão as estratégias corporativas de sustentabilidade discutidas mais adiante. Na sequência, são expostas as teorias das externalidades, consideradas importantes falhas de mercado; estas teorias estão na essência dos fundamentos econômicos e políticos de grande parte dos problemas socioambientais atuais. Após as reflexões sobre externalidades, é apresentado o referencial teórico de sustentabilidade no nível da firma. Nesta etapa, são apresentados como os conceitos ligados ao desenvolvimento sustentável e às externalidades impactam as estratégias corporativas para sustentabilidade.

Esquematicamente, a revisão da bibliografia está organizada da seguinte maneira:

Figura 1: Visão geral da revisão bibliográfica:

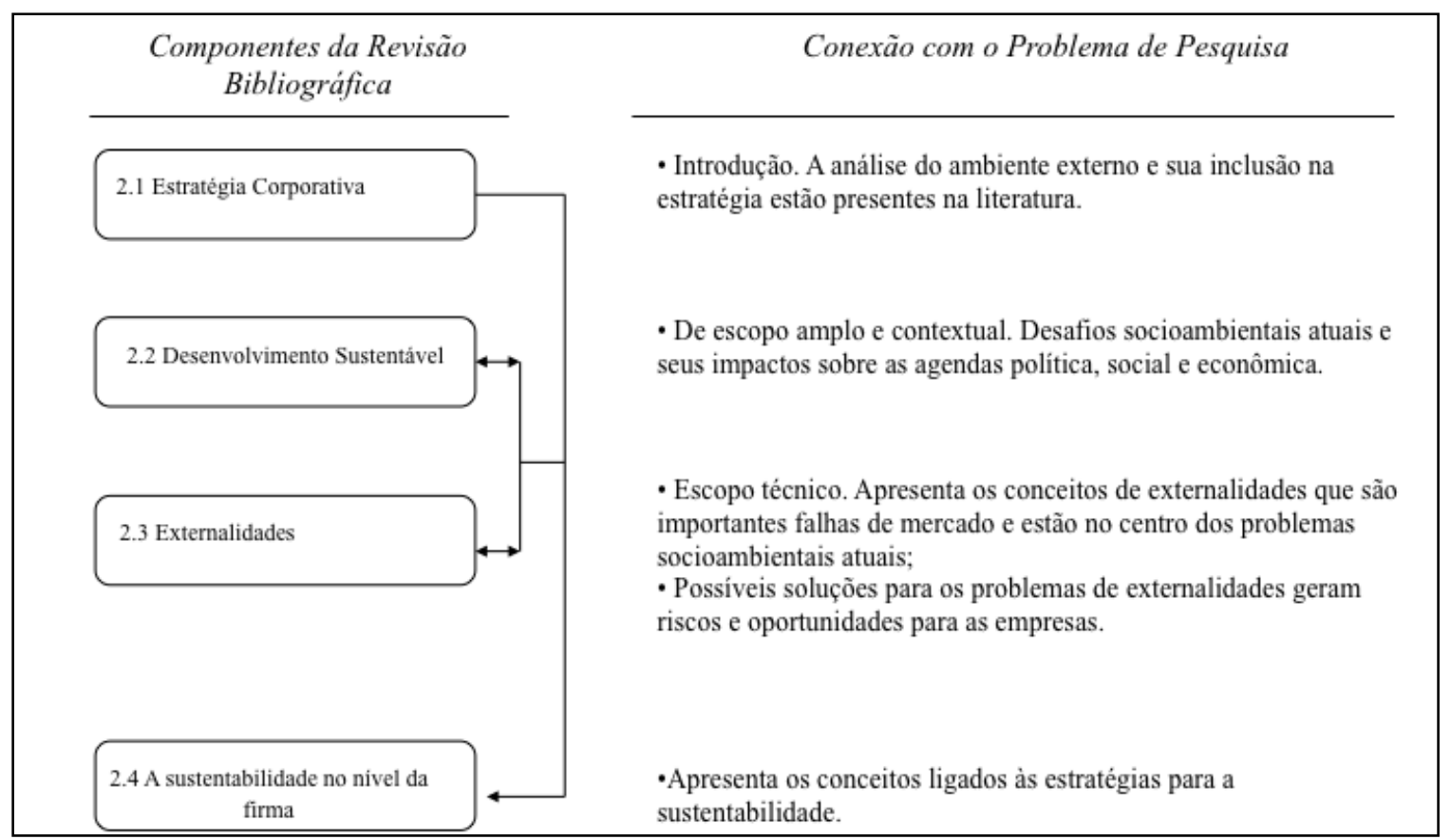

Fonte: Elaboração própria 


\subsection{Introdução: a estratégia corporativa}

Estratégia é um termo que tem sua origem na Grécia antiga e que significava um juiz ou um comandante militar. A importância do pensamento estratégico aplicado ao contexto competitivo começa a crescer a partir da segunda metade do século XIX, quando os mercados para as massas começam a surgir impulsionados, principalmente, pelo desenvolvimento das ferrovias em 1850. Este fator, aliado a maior acesso a crédito e a capital, encorajaram investimentos em larga escala na produção e em economias de escopo na distribuição. A partir da Segunda Guerra Mundial, o pensamento estratégico ganha novo impulso quando o problema de alocação de recursos escassos na economia do período de guerra gerou diversas inovações na ciência da gestão. É quando começam a surgir conceitos importantes para o pensamento competitivo estratégico (com suas origens em estratégias militares), como a teoria dos jogos e o das curvas de aprendizagem. É também quando avança a ideia de que a estratégia é um processo formal de gestão e que deve guiar as decisões de gestão dos negócios. Bastante impulsionado pelas ideias de Peter Drucker, o processo de gestão estratégica passa a estar fundamentado no planejamento formal e na tentativa da organização de moldar o ambiente econômico de negócios, buscando exercer controle positivo sobre as forças de mercado. A partir do fim da Segunda Guerra Mundial, com a necessidade de reconstruir a Europa e a Ásia e considerando o excesso de demanda, a importância do planejamento estratégico diminuiu, para recuperar importância a partir das décadas de 1950 e 1960 em função do aumento da competição global (GHEMAWAT, 2002).

Ao longo de sua relativa recente aplicação aos negócios, o termo estratégia e seus desdobramentos (como o processo de gestão da estratégia, de planejamento estratégico) receberam várias contribuições teóricas. Porém, quase sempre o significado do termo estratégia está atrelado a um processo consciente de definição de diretrizes que determinam as decisões futuras (MiNTZBERG, 1978).

Para Ansoff e Mc Donnell (1993), uma estratégia é um conjunto de regras de tomada de decisão para orientação do comportamento de uma organização. A estratégia representa os meios para se atingir os fins que a empresa está tentando alcançar. Para Andrews (1980), uma decisão estratégica está ligada ao desenvolvimento de longo-prazo da organização: 
“A estratégia corporativa é o padrão de decisões em uma organização que determina e revela seus objetivos, propósitos, metas, que produz as políticas e planos para o atingimento destas metas e define que negócios a organização deve perseguir, que tipo de organização econômica e humana deseja tornar-se e a natureza da contribuição econômica e não-econômica que pretende realizar para seus acionistas, funcionários, clientes e comunidade" (ANDREWS, 1980, p. 18-19).

Mintzberg (2007) argumenta que o processo de formulação da estratégia não é sempre ordenado, formal e absolutamente racional, mas ao contrário, está mais próximo de um processo artesanal. Estratégias podem ser deliberadas - como resultado de um processo ordenado e racional -, e podem ser emergentes, como respostas à uma determinada situação e contexto. O conceito de estratégia é também apresentado como plano, padrão, posição, perspectiva e truque. Na estratégia como plano, a estratégia pode ser definida como um plano de ação traçado para direcionar a organização. Neste caso, estratégia seria uma direção pretendida, definida de maneira consciente e racional para lidar com situações que se apresentam à organização. Na estratégia como padrão, a estratégia pode ser também considerada um padrão de comportamento por um determinado período de tempo. Neste caso, a estratégia é o comportamento realizado no passado. Como posição, a estratégia representa uma posição de um produto em seu ambiente competitivo, o posicionamento de um produto no mercado em que está inserido. Na estratégia como perspectiva, é a maneira com que a organização faz as coisas ou sua maneira de enxergar o mundo, sua personalidade individual. Esta perspectiva é compartilhada pelos membros de uma organização por meio de suas ações. E finalmente, na estratégia como truque, a estratégia é uma manobra realizada pela organização para "enganar” ou confundir um competidor (MINTZBERG, AHLSTRAND, LAMPEL, 2000).

Fortemente inspirados pela nova economia e pelos negócios "ponto com”, Eisenhardt e Sull (2001) propõem que estratégia é a busca de oportunidades efêmeras usando regras simples, que favoreçam o posicionamento rápido e ágil da organização em ambientes com mudanças rápidas e imprevisíveis. Um processo de planejamento estratégico formal não faria sentido em um contexto competitivo que muda rápido e cujas incertezas são imensas.

A definição de estratégias está inserida no contexto mais amplo da gestão estratégica da organização. O processo de gestão estratégica é um conjunto de compromissos, decisões e ações requeridas de uma organização para que atinja a competitividade estratégica e retornos 
acima da média no longo-prazo. Inputs estratégicos relevantes, que estejam baseados em análises dos ambientes internos e externos à organização são necessários para a formulação e implantação efetivas da estratégia. Também, ações estratégicas efetivas são pré-requisitos para se atingir os objetivos de competitividade estratégica e retornos acima da média no longo-prazo. Assim, o processo estratégico ilustrado abaixo pode ser utilizado para que a firma responda às condições de um mercado que muda de maneira contínua (HITT et al, 2001).

Figura 2: O processo de gestão estratégica

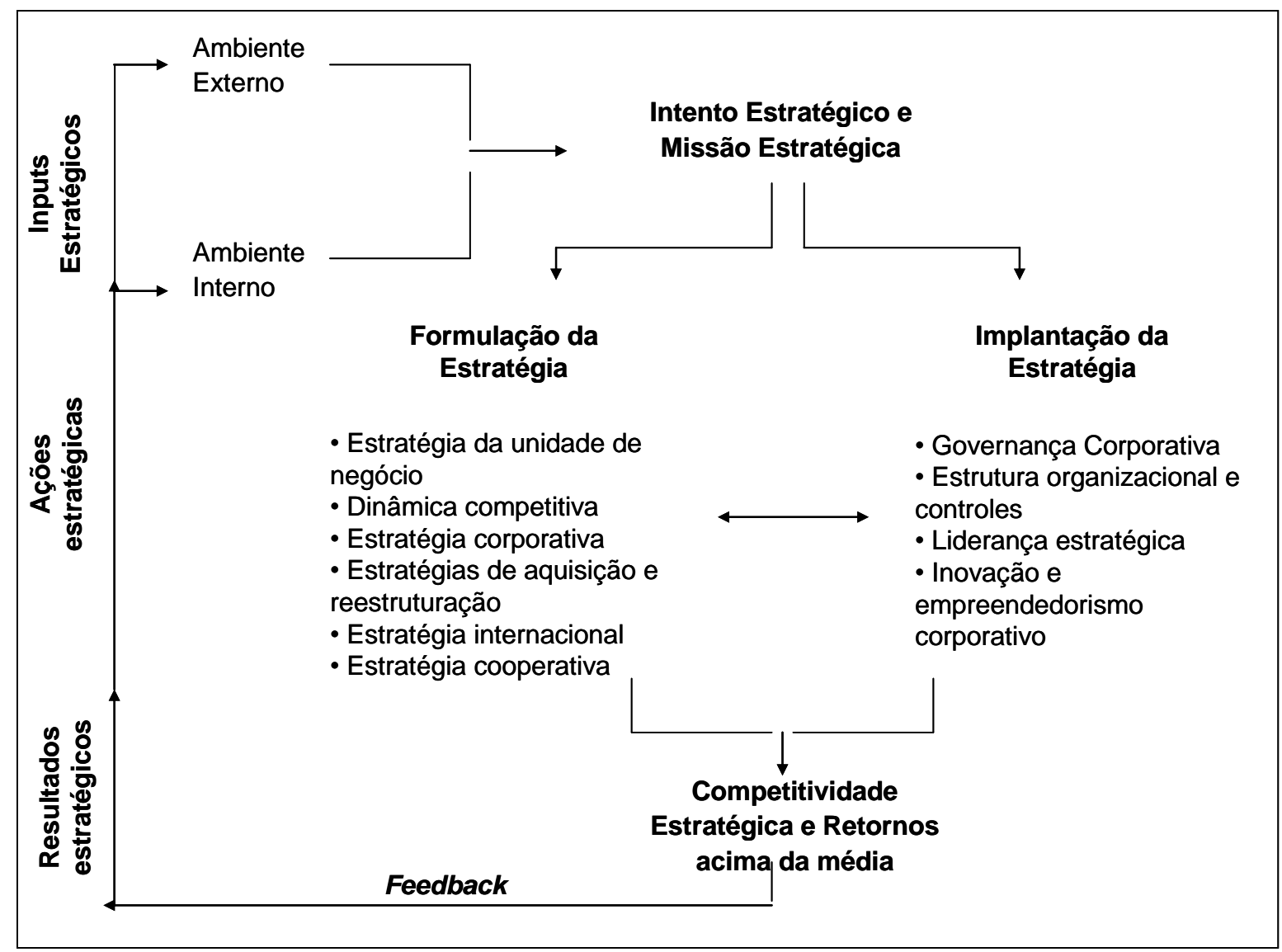

Fonte: Adaptado de Hitt et al, 2001, p. 6

Ao longo da história do pensamento estratégico, diversas abordagens sobre os conceitos do processo de gestão estratégica foram desenvolvidas. Na década de 1950, Kenneth Andrews, professor de Harvard, foi um dos pioneiros a considerar que o processo de formulação estratégica é deliberado e intencional. Na década de 1960, o surgimento da análise de forças e fraquezas, oportunidades e ameaças, a análise SWOT (a sigla em inglês referente a Strengths, Weaknesses, Opportunities and Threats), trouxe novo ímpeto ao conceito de estratégia ao 
considerar a avaliação da empresa em relação ao seu mercado competitivo. As décadas de 1960 e 1970 viram o surgimento dos consultores em estratégia como o The Boston Consulting Group, que criou sua versão própria da curva de experiência para tentar explicar preços e o comportamento competitivo em setores de crescimento rápido. Popularizou também a matriz de crescimento versus participação, uma ferramenta simplificada para análise de carteira de produtos. Em 1980, os conceitos da Organização Industrial foram a base para Michael Porter propor um framework para a análise estrutural da atratividade de uma determinada indústria quando lançou, em 1980, seu livro "Estratégia Competitiva". Porter apresentou o framework das cinco forças, em que a competitividade e atratividade de uma indústria (setor produtivo) dependem da rivalidade entre os competidores, da força dos produtos substitutos, do poder de barganha dos fornecedores e dos consumidores e da abertura a novos entrantes. Depois, dois estrategistas envolvidos com a teoria dos jogos, Brandenburger e Nalebuff, propuseram que o processo de criação de valor depende de quatro tipos de agentes: clientes, fornecedores, competidores e complementadores; por complementadores os autores se referem a outras firmas cujos clientes compram produtos e serviços complementares ou para quem os fornecedores vendem recursos complementares. Seriam estes, portanto, os principais objetos de atenção dos gestores no sentido de estabelecer alianças estratégicas e parcerias. Em 1985, com a publicação do livro "Vantagem Competitiva", Michael Porter popularizou o conceito de cadeia de valor como fonte de diferenciação competitiva e vantagem em custo. Ainda na década de 1980, surgiu o conceito da firma como recursos, visão da estratégia em que a competitividade organizacional depende de a firma possuir recursos escassos e específicos. Em particular um artigo de 1990 de Prahalad e Hamel "As competências essenciais da corporação" expressa que no longo prazo, a competitividade deriva das competências essenciais que levam à inovação em novos produtos. Já na década de 1990, as teorias das capacidades dinâmicas ganharam o terreno da estratégia ao propor que as capacidades em uma organização podem ser desenvolvidas e que, portanto, o processo de aquisição, aprendizagem e acúmulo de capacidades é essencial no processo estratégico (GHEMAWAT, 2002).

O processo de formulação de estratégias estipula as direções gerais para onde a empresa deve direcionar seus esforços em busca de crescimento e desenvolvimento. A estratégia dever ser usada para focar a atenção da organização em áreas por ela definidas e identificar e eliminar possibilidades que sejam incompatíveis. Sempre que haja mudanças rápidas e descontínuas no ambiente da empresa, seja pela saturação de mercados tradicionais, descobertas tecnológicas 
ou mudanças no ambiente concorrencial, um processo estratégico é necessário. Isto para que a organização tenha um processo explícito que lhe ajude a escolher as direções para o crescimento futuro - dentre muitas opções - e mobilizar as energias de um grande número de pessoas na direção escolhida (ANSOFF, MC DONNELL, 1993).

Decorre da análise estratégica a definição de um modelo de negócios que contribua para a captura de valor pela organização; a estratégia da organização funciona como um filtro para a definição do seu modelo de negócios. Um modelo de negócios articula a lógica que explicita como um negócio cria e entrega valor a seus clientes e como transforma receita em lucro (TEECE, 2010; DEMIL, LECOCQ, 2010). É preciso, portanto, não apenas inovar em produtos, mas também no desenho do modelo de negócios, compreendendo as opções possíveis, as necessidades dos clientes e as trajetórias tecnológicas. O desenho do negócio por si só é insuficiente para assegurar vantagem competitiva já que imitações são sempre possíveis, mas um modelo de negócios diferenciado e difícil de imitar tem maior probabilidade de retornar lucros para seus acionistas. O modelo de negócios é um desenho conceitual e não financeiro do negócio; é o modelo de negócios que ajuda a organização a compreender como deve posicionar-se no mercado competitivo. Os critérios para definição de um bom modelo de negócios são: (i) que contenha proposição de valores que sejam interessantes para os clientes; (ii) alcance estruturas de risco e custo vantajosas; e (iii) e possibilite que a organização capture o valor gerado pela venda de produtos e serviços (TEECE, 2010).

Ainda no processo de gestão estratégica, cabe destacar a análise dos Fatores Críticos de Sucesso, os aspectos essenciais para assegurar o sucesso na implantação de uma determinada estratégia deliberada. Fatores Críticos de Sucesso (FCS) são aqueles aspectos que devem ir bem para assegurar o sucesso para um gestor ou uma organização, e, portanto, representam aquelas áreas da gestão ou da organização que precisam receber atenção especial e contínua para que possam gerar alto desempenho. Fatores Críticos de Sucesso incluem questões vitais para as atividades atuais da organização, assim como para as necessárias para seu sucesso futuro. O método de definição dos FCS é um procedimento que visa explicitar estas áreaschave que ditam o sucesso organizacional (BOYNTON, ZMUD, 1984).

- Estratégia e risco 
O processo de gestão estratégica engloba a habilidade da organização em lidar com mudanças frequentemente abruptas causadas por novos desenvolvimentos de mercado, eventos políticos, avanços tecnológicos e ameaças ambientais que confrontam as atividades produtivas em escala global. Portanto, parte importante do processo de gestão estratégica é a identificação e gestão de riscos estratégicos. Estes riscos afetam tanto grandes organizações como pequenas e médias, assim como instituições públicas e demais comunidades. Assim, a gestão de risco tem muitas ramificações e se aplica a organizações públicas e privadas bem como formuladores de políticas públicas (ANDERSEN, SCHRODER, 2010).

Risco está ligado a variações nos resultados esperados de uma empresa (CLARKE, VARMA, 1999; HAGIGI, SIVAKUMAR, 2009; LESSARD, LUCEA, 2009). As corporações contemporâneas estão expostas a diversos tipos de riscos, variando de catástrofes naturais a falhas de comportamento humano. Risco está em todo lugar, como evidenciado pelos escândalos corporativos que atingiram grandes companhias como Baring Brothers, WorldCom, Enron, Parmalat, Leman Brothers, entre outras. Desastres naturais e causados por ações humanas também abundam, causando impactos econômicos diretos e indiretos sobre as organizações. Portanto, gestão de risco corporativo tornou-se um aspecto fundamental do desenvolvimento da estratégia porque fraca gestão de risco pode levar à falência e boa gestão de risco pode melhorar os resultados corporativos. Portanto, gestão de risco é o processo que contribui para a criação de vantagem competitiva sustentada (ANDERSEN, SCHRODER, 2010; HAGIGI, SiVAKUMAR, 2009; LeSSARD, LUCEA, 2009; Clarke, VARMA, 1999).

A satisfação das necessidades dos stakeholders é mais arriscada hoje que no passado, em parte em razão da globalização, já que fornecedores e clientes dispersos pelo mundo oferecem grandes oportunidades de negócios, mas também trazem maior complexidade e riscos políticos e monetários. Consequentemente, há uma grande probabilidade de ocorrência de eventos não planejados. Gestão de risco é um processo estratégico: os gestores precisam avaliar se as atividades de uma empresa são consistentes com seus objetivos estratégicos, se o processo de gestão de riscos se relaciona com as decisões de investimentos e de crescimento, quais os retornos a organização espera de suas atividades. Também, o Conselho precisa exercer a supervisão da exposição da organização ao risco, ao mesmo tempo em que assegura a boa governança (CLARKE, VARMA, 1999). 
De maneira geral, o processo de gestão de risco segue as seguintes etapas: identificação, análise, avaliação dos riscos e definição dos mecanismos de resposta aos riscos. Os principais riscos aos quais a organização está exposta precisam ser identificados, assim como a utilização de técnicas para analisar frequência dos eventos e potenciais impactos; com base nestas análises, os gestores organizacionais decidem o curso de ação a ser tomado, incluindo a adoção de esforços para mitigação dos riscos e/ou adoção de atividades que transferem risco para terceiros (contratação de seguro, por exemplo) para que a organização permaneça dentro dos limites de risco considerados adequados. No processo de gestão estratégica é preciso considerar também os riscos estratégicos, ou seja, aqueles que podem comprometer os resultados desejados desenhados ao longo do processo estratégico (ANDERSEN, SCHRODER, 2010).

Andersen e Schroder (2010) apresentam a seguinte tipologia de fatores de riscos aos quais uma organização está exposta, assim como as possíveis respostas a estes riscos: 
Figura 3: Tipologia de riscos segundo Andersen e Schroder (2010):

\begin{tabular}{|c|c|c|c|}
\hline Categorias de Riscos & Fatores de Riscos & Origem & Possíveis respostas \\
\hline Estratégicos & $\begin{array}{l}\text { - Movimentos dos competidores } \\
\text { - Novas regulações } \\
\text { - Eventos políticos } \\
\text { - Mudanças sociais } \\
\text { - Mudanças de preferências } \\
\text { - Novas tecnologias }\end{array}$ & Exógena & $\begin{array}{l}\text { - Desenvolvimento de } \\
\text { negócios } \\
\text { - Inovação } \\
\text { - Capacidade de resposta } \\
\text { - Análise Estratégica } \\
\text { - Análise ambiental }\end{array}$ \\
\hline Operacionais & $\begin{array}{l}\text { - Falhas produtivas } \\
\text { - Erros administrativos } \\
\text { - Colapso tecnológico } \\
\text { - Falhas de compliance } \\
\text { - Exposições legais }\end{array}$ & Endógena & $\begin{array}{l}\text { - Valores corporativos } \\
\text { - Controles internos } \\
\text { - Aprendizado contínuo } \\
\text { - Gestão da Qualidade Total } \\
\text { - Certificações }\end{array}$ \\
\hline Econômicos & $\begin{array}{l}\text { - Demanda geral } \\
\text { - Relações de preços } \\
\text { - Taxas de câmbio } \\
\text { - Taxas de juros } \\
\text { - Preços de commodities }\end{array}$ & $\begin{array}{l}\text { Principalmente } \\
\text { exógena }\end{array}$ & $\begin{array}{l}\text { - Flexibilidades estruturais } \\
\text { - Diversificação } \\
\text { - Derivativos financeiros } \\
\text { - Gestão estratégica do caixa }\end{array}$ \\
\hline Gerais & $\begin{array}{l}\text { - Catástrofes naturais } \\
\text { - Desastres causados } \\
\text { por humanos } \\
\text { - Eventos terroristas } \\
\text { - Mortes }\end{array}$ & $\begin{array}{l}\text { Principalmente } \\
\text { exógena }\end{array}$ & $\begin{array}{l}\text { - Seguros } \\
\text { - Financiamento e } \\
\text { transferência do risco } \\
\text { - Esforços de mitigação de } \\
\text { riscos } \\
\text { - Prevenção }\end{array}$ \\
\hline
\end{tabular}

Fonte: Elaboração própria baseado em Andersen e Schroder (2010)

A gestão eficiente de risco pode ser fonte de vantagem competitiva para uma organização e não apenas uma forma de minimizar perdas. Mas para que a gestão de risco represente efetivamente fonte de vantagem competitiva sustentada, a organização precisa desafiar quatro mitos bastante difundidos nas práticas e pesquisas atuais sobre gestão de risco: o de que as várias fontes de risco para a organização são independentes umas das outras, o de que risco pode ser gerenciado apenas por meio de instrumentos financeiros, o mito que "gerir risco" pode ser separado de "gerir o negócio" e, finalmente, o mito que todos os riscos que uma empresa enfrenta estão no radar da alta gerência (LESSARD, LUCEA, 2009). 


\subsection{Desenvolvimento sustentável}

Porrit (2007) sintetiza bem os principais desafios do mundo neste começo do século XXI: o imperativo biológico e o imperativo político. O imperativo biológico trata da necessidade urgente de aprendermos a viver de maneira sustentável neste planeta. É um imperativo imposto pelas leis da natureza e, portanto, não é negociável. O segundo imperativo, o político, trata da aspiração de melhorarmos nossos padrões materiais ano após ano. É um imperativo relativo e politicamente determinado. A urgência na conciliação entre estes dois imperativos está na essência do desenvolvimento sustentável.

“A necessidade de conciliarmos estes dois imperativos nunca foi tão urgente. O mundo transformou-se completamente nos últimos 60 anos, com uma combinação de crescimento populacional rápido e crescimento maciço da atividade econômica - direcionada pelo acesso relativamente barato de fontes como carvão, óleo e gás - impondo uma severa carga sobre o ambiente natural" (PORRIT, 2007, p.4)

Os desafios socioambientais do mundo contemporâneo são indiscutíveis. Questões como pobreza, fome, iniquidade de desenvolvimento humano, aliadas a questões ambientais como desertificação do solo, produtividade decrescente da produção agrícola, poluição severa, chuva ácida, poluição das águas, redução drástica da biodiversidade, mudanças climáticas apenas para citar algumas -, impactam, de maneira crescente, as dimensões políticas e econômicas da vida em sociedade. Para Sachs (1995), o termo desenvolvimento tem sido acompanhado de uma profusão de adjetivos tais como econômico, social, político, cultural, durável, humano. Mas, para ele, desenvolvimento é um conceito comandado pelo social, que tem o ecológico como restrição e o econômico como instrumento.

A origem das reflexões sobre o desenvolvimento sustentável está na ecologia e na economia, já que um dos principais desafios é adequar a escala da produção econômica aos limites naturais:

"Embora já haja debates sobre a noção de sustentabilidade em quase todas as áreas do conhecimento, eles obrigatoriamente têm suas raízes nas reflexões que ocorrem em duas disciplinas consideradas científicas: a ecologia e na economia." (VEIGA, 2009, p.21).

Na economia, os conceitos de sustentabilidade e desenvolvimento sustentável têm sua origem na macroeconomia e a questão central é como manter o bem-estar per capita ou a utilidade 
per capita das gerações atuais e futuras. Nestas reflexões, normalmente os economistas utilizam a abordagem da teoria de capital, considerando que o desenvolvimento pode ser sustentável se forem mantidos constantes ou os estoques ou os fluxos de serviços prestados por quatro tipos de capital - capital é entendido como algo que produz ou contribui para um fluxo de resultados (output): (i) infraestrutura manufatureira, que nas teorias econômicas é conhecido apenas como capital; pode ser acumulado por meio de investimentos e seu acúmulo gera mais produção econômica; (ii) natural, correspondendo às funções ambientais, podendo ser dividido em renovável e não renovável; (iii) humano, relacionado à educação e habilidades possuídas pelos indivíduos; e (iv) social, referindo-se ao conhecimento e regras contidas nas culturas e instituições (como por exemplo, os sistemas legais); às maneiras que os atores econômicos interagem e se organizam. Um sistema sustentável deve impedir a degradação de seu estoque de capital e os quatro tipos necessitam de manutenção contínua (Harris et al, 2001; Goodland, 2003; Figge, Hahn, 2004). Para Pearce e Turner (1990) o desenvolvimento sustentável envolve a maximização dos benefícios líquidos do desenvolvimento econômico, sujeito à manutenção dos serviços e qualidade dos recursos naturais ao longo do tempo. Desenvolvimento econômico é entendido não apenas como o aumento de renda per capita, mas também a inclusão de elementos de bem-estar social; desenvolvimento necessariamente envolve mudanças estruturais dentro de uma economia e na sociedade. A manutenção dos serviços e qualidade do estoque dos recursos ao longo do tempo implica a aceitação de se utilizar recursos renováveis a taxas menores ou iguais às suas taxas de regeneração e otimizar a eficiência com a qual recursos não renováveis são usados, sujeito à substituição entre recursos e avanços tecnológicos. Assim, desenvolvimento econômico e manutenção dos recursos naturais estão relacionados de duas maneiras: até certo ponto de utilização da base de recursos, é provável que haja um trade-off entre desenvolvimento e os serviços ecossistêmicos; acima deste nível, o desenvolvimento econômico envolverá a redução em um ou mais serviços prestados pelos ecossistemas.

Os economistas clássicos dos séculos XVIII e XIX consideravam os recursos ambientais necessários para a atividade econômica de duas formas: como não-escassos (como o ar) ou não-esgotáveis (como a terra arável). Desta forma, um aumento no volume da produção econômica de um ano para outro representava não apenas um ganho - oriundo do aumento do consumo imediato-, como também uma melhoria na base de recursos sobre a qual os futuros resultados da atividade econômica poderiam ser atingidos. O sucesso no curto prazo era resultado tanto do aumento do potencial de consumo como do acúmulo de capital no longo 
prazo. Crescimento sustentável era, portanto, a manutenção do crescimento de curto prazo. Porém, há recursos naturais esgotáveis e serviços ambientais essenciais podem ser irreversivelmente prejudicados em razão de poluição ou mudanças no ecossistema. Portanto, a atividade econômica pode ter altos custos de oportunidade intertemporais. A existência destas irreversibilidades altera a relação clássica entre desempenho de curto-prazo e prospectos de longo-prazo para (i) a produção econômica e níveis de consumo; e (ii) a sustentação dos ciclos de renovação dos recursos e das funções ambientais que apóiam a vida e que estão na base da atividade econômica. Deste modo, é possível reconhecer que o curto e longo prazos podem estar em conflito; a busca pelo crescimento econômico rápido como objetivo de curtoprazo pode impossibilitar o bem-estar econômico das futuras gerações (FAUCHEUX et al, 1997).

$\mathrm{Na}$ esteira destas discussões, vêm os conceitos de sustentabilidade fraca e forte. Sustentabilidade fraca aplica os conceitos de eficiência econômica à gestão dos serviços da natureza; considera que todas as formas de capital são substituíveis umas pelas outras e que a perda em um tipo de capital em teoria pode ser substituída por excedentes em outras formas de capital. A crença de que nem todas as formas de capital são perfeitamente substituíveis e a necessidade de conservar estoques de capital natural críticos não substituíveis formam o conceito de sustentabilidade forte (FIgGe, HAHN, 2004; FAUCHEUX, NoËL, 1995; VeIGA, 2010).

O conceito de desenvolvimento sustentável ainda não é unânime na literatura científica; as origens do termo assim como as contribuições de diferentes escolas do pensamento são confusas (BARBIERI et al 2010). No entanto, aspectos ligados ao desenvolvimento sustentável, como, por exemplo, desenvolvimento, equanimidade social, limites ambientais, não são necessariamente novos para os economistas (CLARK, 1916; NELSON, 1995; FAUCHEUX, NOËL, 1995; ABRAMOVAY, 2009; BARBIERI et al, 2010).

O conceito proposto pela Comissão Brundtland, o de - "satisfazer as necessidades do presente sem comprometer a capacidade de as futuras gerações satisfazerem suas próprias necessidades" (ALMEIDA, 2002, p.56) - é bastante criticado por ser considerado uma definição pobre e inoperante. Algumas correntes críticas consideram que, ao se tomar por base a definição de Brundtland, a integridade dos recursos naturais deveria ser mantida independente 
das preferências humanas, ou que o termo pode evoluir para um "termo de efeito" (catchphrase) desprovido de qualquer sentido conceitual, prático e operacional (LELÉ, 1991; HOWARTH, 1997; GIDDENS, 2009). A própria expressão “desenvolvimento sustentável” é criticada por ter significado contraditório, já que "sustentável" implica em continuidade e equilíbrio, enquanto "desenvolvimento" implica em dinamismo e mudança. Assim, os ambientalistas são tocados pelo ângulo da sustentabilidade, enquanto governos e negócios colocam o foco no termo desenvolvimento (GIDDENS, 2009). Há quem considere o conceito de sustentabilidade um "retrocesso intelectual", imposto como limite às escolhas políticas sem estar baseado na concepção de bem-estar social, enfraquecendo a alocação eficiente de recursos ao forçar os tomadores de decisões a conservarem os ativos naturais mesmo nos casos em que maiores benefícios poderiam ser obtidos pela substituição do capital reproduzido por óleo, florestas antigas, e outros recursos (DASGUPTA e MÄLER 1995 apud HowARTH, 1997). Ou ainda quem considere que a definição de sustentabilidade é vaga e seu significado pertence mais à ética que à ciência; e que a sustentabilidade deveria ser entendida como uma "obrigação de conduta de maneira a deixar para o futuro a opção ou a capacidade de estarem tão bem quanto nós estamos" (Solow, 1991 apud NELSON, 1995, p.141). A economia ecológica apresenta a questão da sustentabilidade como o desenvolvimento sem a expansão de sua base física, ou seja, o desenvolvimento sem crescimento e que este deveria ser o entendimento correto do termo "desenvolvimento sustentável” (DALY, 1993; DALY e FARLEY, 2004; VEIGA, 2009).

Para Porrit (2007), sustentabilidade é a capacidade de continuidade no futuro de longo-prazo; sustentabilidade é o objetivo último, o destino desejado para a espécie humana e para qualquer outra espécie. Na mesma linha, Furtado (2005) explica que o termo sustentável significa defensável, suportável, capaz de ser mantido e preservado, se determinadas condições e recursos não forem depletados, debilitados ou danificados permanentemente. Desenvolvimento sustentável seria então o processo pelo qual nos movemos no sentido da sustentabilidade (PORRIT, 2007). Apoiado na definição da Comissão Brundtland, Furtado (2005) define desenvolvimento sustentável como sendo a aquisição quantitativa e qualitativa de bens e serviços providos pela natureza para atendimento das necessidades econômicas, ambientais e sociais dos atuais integrantes de todos os setores da sociedade humana, sem comprometer o direito das gerações futuras de disporem de bens e serviços naturais para atenderem a suas próprias necessidades. 
Para Lafferty e Meadowcroft (2000) mais importante que os conceitos dos termos sustentabilidade e desenvolvimento sustentável é a compreensão de quais são, efetivamente, os objetivos que estes conceitos expressam. Para eles, desenvolvimento sustentável é uma visão interdependente entre a promoção do bem-estar humano, satisfazendo suas necessidades básicas; é a proteção do ambiente natural, considerando o destino das gerações futuras; é atingir equidade entre ricos e pobres; é ampla participação nos processos decisórios.

Fortemente amparado nas leis da termodinâmica (as bases também para a economia ecológica), Robèrt (2002, p.80) apresenta o princípio para uma sociedade sustentável:

" $\mathrm{Na}$ sociedade sustentável, os fluxos da matéria são equilibrados ou, pelo menos, não sistematicamente desequilibrados. Os ciclos naturais envolvem a sociedade e definem os limites nos quais devemos viver. A sociedade sustentável vive em parte dos fluxos da produção da natureza e em parte dos fluxos menores de metais e minerais da crosta terrestre. As plantas produzem recursos bastante renováveis para satisfazer ao consumo por parte dos animais e dos humanos. Uma parte dos recursos naturais - átomos dispersados 3,5 bilhões de anos atrás, mas agora concentrados e estruturados no que nos referimos como carne, peixe, madeira, polpa, combustíveis, remédios, e assim sucessivamente - é conduzida de maneira organizada pela sociedade. Desde que (na sociedade sustentável) a taxa desse fluxo não exceda a taxa de regeneração dos recursos, esta pode ser considerada como uma "taxa de juros" da natureza em vez de um preço cobrado sistematicamente pelo seu "capital". Os recursos são reciclados e usados de maneira eficaz de forma que as necessidades humanas sejam atendidas efetivamente. Parte da matéria pode ser extraída da crosta terrestre como recursos (da mineração e da perfuração de poços de petróleo, por exemplo), mas a maioria dos fluxos minerais é reciclada dentro da sociedade. Alguns dos fluxos da sociedade terminam como estruturas muito duradouras, como edifícios (que poderiam ser reciclados em novos edifícios). Por causa da segunda lei da termodinâmica, tais estruturas também devolveriam fluxos consideráveis de matéria corroída e desgastada aos ecossistemas. Esses fluxos de recursos lentamente degradados são acompanhados por alguns fluxos mais amplos (mesmo em uma perspectiva a curto prazo), como alimentos e combustíveis consumidos, que rapidamente terminam na natureza como elementos básicos para novos recursos da produção primária: fumaças e dejetos orgânicos tornam-se novas florestas, plantas, algas e animais. Uma minúscula parte dos detritos da sociedade também poderia entrar nos processos mais lentos de sedimentação geológica. Assim são mantidos limpos a atmosfera, as águas e os solos, ao mesmo tempo em que temos um fluxo sustentável de recursos para satisfazer às nossas necessidades."

Apresenta também as quatro condições sistêmicas para a sustentabilidade: (i) na sociedade sustentável, a natureza não está sujeita a concentrações sistematicamente crescentes de 
substâncias extraídas da crosta terrestre; (ii) na sociedade sustentável, a natureza não está sujeita a concentrações sistematicamente crescentes de substância produzidas pela sociedade; (iii) na sociedade sustentável, a natureza não está sujeita à degradação sistematicamente crescente por meios físicos; e (iv) na sociedade sustentável, as necessidades humanas são satisfeitas em todo o mundo (RoBÈRT, 2002).

Desenvolvimento sustentável pode ser entendido também como internalização de externalidades; desenvolvimento sustentável seria o desenvolvimento que maximiza os benefícios líquidos no longo prazo para a humanidade levando em conta os custos da degradação ambiental. Por benefícios líquidos entende-se não apenas o aumento de renda ou redução de desemprego e pobreza, mas também condições de vida mais saudáveis e outros benefícios associados com a melhor qualidade do meio ambiente. Sob este pressuposto, a ênfase sobre o desenvolvimento sustentável não estaria na redução do crescimento, mas sim na necessidade de crescer e desenvolver de forma sensata, assegurando que os benefícios do desenvolvimento sejam duradouros (SCHMANDT e WARD, 2000).

Harris et al (2001) apresentam a síntese dos aspectos essenciais para o desenvolvimento sustentável: (i) econômico - um sistema economicamente sustentável deve ser capaz de produzir produtos e serviços continuamente, manter níveis de dívidas governamental e externa gerenciáveis, evitar desequilíbrios setoriais que prejudicam a produção industrial e agrícola; (ii) ambiental - um sistema ambientalmente sustentável mantém uma base estável de recursos, evitando a super exploração de recursos renováveis ou a degeneração ambiental e o uso de recursos não renováveis somente na extensão em que investimentos forem feitos em substitutos adequados; inclui manutenção da biodiversidade, estabilidade da atmosfera e outras funções ecossistêmicas não comumente classificadas como recursos econômicos; (iii) social - um sistema socialmente sustentável obtém justiça na distribuição de renda e oportunidades, provisão adequada de serviços sociais, incluindo saúde e educação, tratamento igualitários dos gêneros e participação e assunção de responsabilidades por parte do governo (HARRIS et al, 2001).

\subsection{Externalidades}

No centro dos problemas socioambientais atuais está o conceito de externalidade. Este é um tema central para a crítica neoclássica da organização dos mercados (BUCHANAN, 
Stubblebine, 1962; Faucheux, Nö̈L, 1995). Externalidades existem porque há bens demandados pelas pessoas para os quais não existem mercados. $\mathrm{O}$ conceito de externalidade está, portanto, ligado a falhas de mercado. Externalidades surgem quando uma variável real escolhida por um agente econômico entra na função produção ou utilidade de outros agentes econômicos e não há obrigatoriedade ou incentivo ao primeiro agente para que considere os efeitos que sua escolha gera em outros (MOTTA, 1997; FREEMAN III, 2003; VARIAN, 2006)

A teoria econômica neoclássica - baseada na premissa dos mercados concorrenciais-, para incorporar os impactos negativos sobre o ambiente natural da produção econômica (ou seja, impactos extra-econômicos) desenvolveu o conceito de externalidades que representam falhas de mercado:

“A economia neoclássica, cuja análise assenta sobre o sistema de mercados concorrenciais, poderia parecer bastante desprovida para tomar em conta fenômenos claramente pertencentes ao domínio extra-econômico, ou até ao domínio da natureza, pela sua origem, mas que, no entanto, não deixam de ter vínculos com a esfera das atividades econômicas. Ela gerou, contudo, com o conceito de efeito externo (ou, mais precisamente, com de deseconomia externa), uma representação da falência do mercado, suscetível, ao mesmo tempo, de oferecer uma descrição dos fenômenos de nocividade e de poluição coerente com a sua definição do econômico e também de fornecer instrumentos de correção de tais fenômenos, correção suscetível de reconduzir a economia ao seu estado ótimo"(FAUCHEUX, NOËL, 1995, p.215)

Aspectos relacionados às potenciais fontes de falhas de mercado são apontados nos trabalhos de Adam Smith e David Hume e discussões mais aprofundadas podem ser encontrados nos trabalhos de Pigou (1932), Samuelson (1948), Coase (1960) e Marshall (1964). Adam Smith, normalmente visto como o pai do laissez-faire, reconheceu a necessidade de intervenção governamental em um grande número de áreas, incluindo o estabelecimento do sistema de justiça, a criação de um sistema que faça cumprir as leis, proteção contra invasão, a provisão de escolas e outros bens públicos. Portanto, o interesse em bens públicos cujos benefícios afetam simultaneamente grupos de indivíduos pode ser encontrado na história do pensamento econômico e político desde os clássicos (FAUCHEUX, NoËL, 1995; CORNES, SANDLER, 1996).

Pigou é quem dá os fundamentos da teoria padrão das externalidades, em que a ação de um agente econômico influencia a função utilidade ou produção de outro agente e não há um mecanismo de compensação (FAUCHEUX, NoËL, 1995; CORNES, SANDLER, 1996). Ele aponta 
que interesses públicos e privados podem não coincidir quando o custo marginal social (que é o custo - para um grupo de indivíduos tomados em conjunto - de se produzir uma unidade adicional de um determinado produto) for diferente do custo marginal privado (o custo para um indivíduo de se produzir uma unidade adicional de um determinado produto). Portanto, há presença de externalidade quando o custo social marginal e o custo marginal privado são diferentes (FAUCHEUX, NOËL, 1995, p.99):

"É igualmente preciso notar que Pigou é o primeiro, em Economics of Welfare, a tomar, a fim de ilustrar uma análise do bem-estar, exemplos claramente dependentes do meio ambiente [...]. É sintomático que, em alguns anos, o mesmo conceito de efeito externo tenha podido passar (pelo preço apenas de uma mudança de marca) da explicação dos benefícios do 'distrito industrial' marshalliano à tomada em conta dos danos devidos ao desenvolvimento desta mesma indústria". (FAUCHEUX, NOËL, 1995, p.100):

"A essência do fenômeno é que uma pessoa A, ao mesmo tempo que fornece a uma outra pessoa $\mathrm{B}$ um determinado serviço pelo qual recebe um pagamento, ocasione na mesma altura vantagens ou inconvenientes de uma natureza tal que não possa ser imposto um pagamento àqueles que dela se beneficiam, nem uma compensação antecipada em proveito daqueles que a sofrem." (PIGOU, 1920 apud FAUCHEUX, NOËL, 1995 p. 216)

"Uma economia externa (ou deseconomia) é um evento que confere benefícios apreciáveis ou impõe danos apreciáveis em alguma pessoa ou pessoas que não foram partes que consentiram no processo decisório que resultou, direta ou indiretamente, no evento em questão" (MEADE, 1973, p.15).

O efeito da externalidade pode ser negativo ou positivo. A ausência de compensação por um pagamento exprime o caráter não comercial que está na origem das externalidades positivas ou negativas. Externa não quer dizer externa à empresa, mas exterior à troca comercial (FAUCHEUX, NOËL, 1995).

Uma externalidade negativa existe na presença de duas condições: quando a atividade de um agente causa perda de bem-estar em outro agente; e quando esta perda de bem-estar não é compensada. Se a perda de bem-estar for compensada, diz-se que a externalidade foi internalizada (PEARCE, TURNER, 1990).

A definição padrão de externalidade, como sendo uma resposta da produção de uma firma ou da utilidade de uma pessoa à atividade de outros pode não ser satisfatória, porque a ideia de que a produção de uma firma ou a utilidade de uma pessoa pode ser influenciada pela atividade de outros também é verdadeira na ausência de efeitos externos. No contexto de um 
sistema interdependente uma mudança exógena no comportamento de indivíduos pode alterar o equilíbrio no preço de um conjunto de produtos e fatores e, portanto, alterar os níveis de utilidade das pessoas e os níveis de produção das firmas. É relevante ressaltar que a essência do fenômeno do efeito externo é que o efeito produzido não é uma criação deliberada, mas um subproduto não intencional ou acidental de uma atividade legítima. Esta noção é fundamental para o estabelecimento de políticas que visem resolver problemas gerados por externalidades (MisHaN, 1971).

Pigou deduziu que o problema das externalidades tem implicação para o bem-estar social: nem todos os mercados concorrentes produzem níveis de produção que maximizam o bemestar total da sociedade (PIGOU, 1932 apud BRUE, 2005). A implicação da teoria da externalidade em Pigou é que é possível se avaliar monetariamente as vantagens ou inconvenientes causados pelo agente privado sobre terceiros. A partir da avaliação econômica e monetária do valor da externalidade causada, seria possível internalizá-la no custo marginal privado do produtor, alterando o preço e a quantidade de equilíbrio. A solução de Pigou para o problema de internalização das externalidades negativas é fiscal, ou seja, por meio do pagamento de impostos. Assim, segundo Pigou, se a produção de uma empresa acarreta efeitos nocivos ao bem-estar de outros agentes econômicos, o único meio de voltar a uma situação ótima em termos paretianos ${ }^{2}$ é preencher o afastamento entre custos marginais sociais e custos marginais privados por meio da imposição de impostos ou subsídios ao produtor privado. Não prevê, portanto, compensação pelos prejuízos sofridos pela vítima e o aspecto fiscal é suficiente para fazer desaparecer a externalidade (FAUCHEUX, NoËL, 1995; VARIAN, 2006; BUCHANAN, 1969).

A figura abaixo ilustra o problema das externalidades negativas mostrando a diferença entre o custo marginal privado e o custo marginal social, pela presença de externalidades negativas. A imposição de um imposto sobre o produtor levaria a um novo equilíbrio, onde a externalidade seria internalizada para este agente econômico, e, portanto, o volume produzido do bem que gera a externalidade seria reduzido ( Q'< Q) e o preço, elevado $\left(\mathrm{P}^{\prime}>\mathrm{P}\right)$.

\footnotetext{
${ }^{2}$ Diz-se que uma situação econômica é eficiente no sentido de Pareto (em homenagem ao economista e sociólogo italiano Vilfrido Pareto, 1848-1923) se não existir nenhum modo de melhorar a situação de algum grupo de pessoas sem piorar a de algum outro grupo. (VARIAN, 2006, p.19)
} 
Figura 4: A presença da externalidade

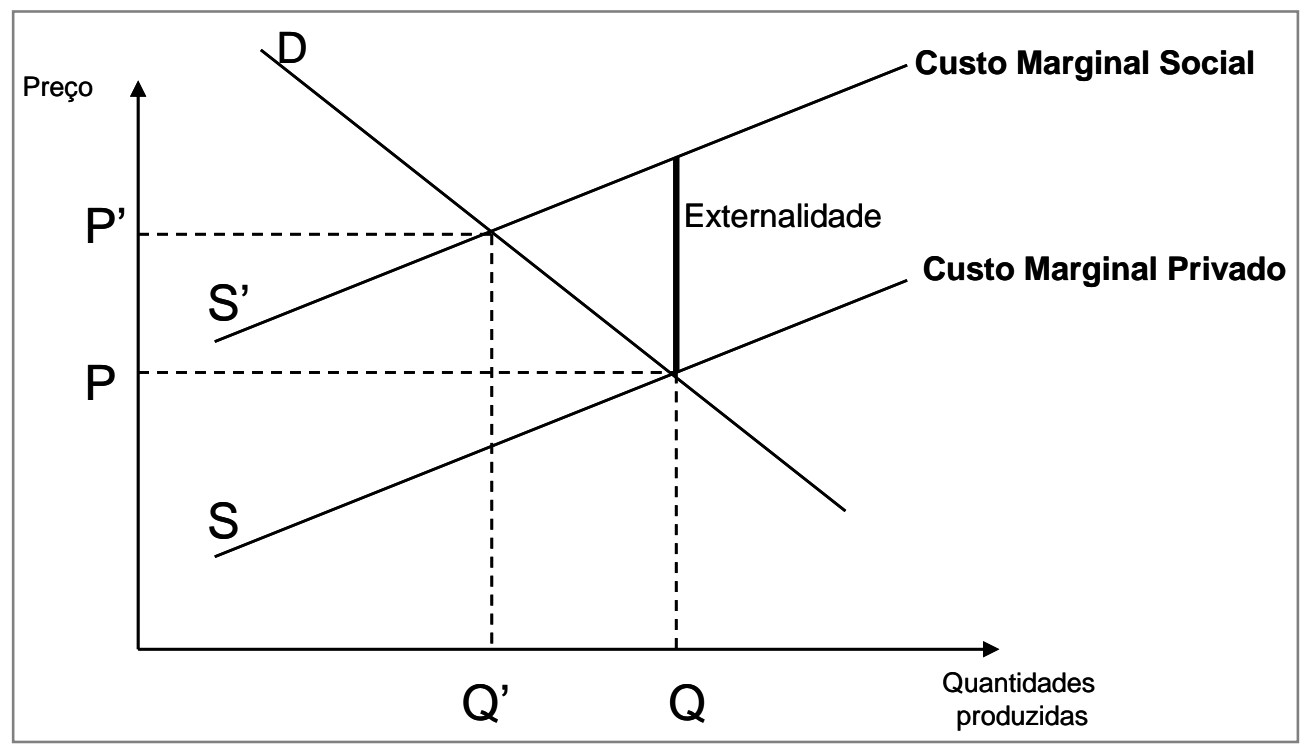

Fonte: FAUCHEUX et al, 1995, p.217

Coase (1960) questiona a solução pigouviana, argumentando que a questão é comumente apresentada de maneira unidimensional, ou seja, (A) impondo malefícios a (B), como no exemplo típico de uma fábrica (A) cuja fumaça causa efeitos danosos à comunidade próxima (B). As soluções baseadas em Pigou poderiam ser:

- A fábrica deve pagar pelos danos causados aos prejudicados pela fumaça; ou

- O governo deve impor um imposto sobre a fábrica que varia com o nível de emissões e é equivalente em termos monetários aos prejuízos que causam; ou

- A fábrica deve ser excluída desta área e de qualquer outra área em que sua fumaça possa ter efeitos negativos sobre outros.

Mas Coase argumenta que não se trata de uma visão unidimensional, mas recíproca, já que para evitar o prejuízo em (B), (A) seria prejudicado. A decisão real é se, então, se deve permitir que (A) prejudique (B) ou se (B) prejudique (A). A solução proposta por Coase, e alternativa a Pigou, é de que a internalização destas externalidades deve vir de uma negociação bilateral de preços entre emissor e vítima, desde que os custos da organização desta negociação (custos de transação) não sejam proibitivos e não ultrapassem os ganhos sociais. Esta negociação bilateral é possibilitada por duas variantes: a primeira, a do pagamento de uma indenização compensatória às vítimas pelo emissor da externalidade; e a segunda, o pagamento pela vítima em potencial de uma soma tal que dissuadiria o emissor a 
manter sua atividade poluidora. Se a escolha será pela primeira ou segunda variantes dependerá da concessão inicial dos direitos de propriedade entre os agentes. Se a poluição de (A) atinge (B), mas (A) é quem possui os direitos de propriedade sobre o ambiente, então a vítima, (B), é quem deve remunerar (A) para que (A) não polua (segunda variante); mas se é (B) quem tem os direitos de propriedade, então (A) é quem deve indenizar (B) pelos prejuízos causados (primeira variante). Segundo o Teorema de Coase, é o valor monetário que (A) e (B) acordarem que determinará o ponto de equilíbrio na negociação. Como os problemas práticos com externalidades surgem devido à má definição sobre os direitos de propriedade, se estes forem bem definidos e se houver mecanismos organizados que permitam às pessoas negociar seus direitos de produzir externalidades, a troca entre os agentes resultaria em uma produção de externalidades mais eficiente (COASE, 1960; FAUCHEUX, NOËL, 1995; VARIAN, 2006).

Buchanan (1969) e Meade (1973) propõem dois grupos de externalidades: pecuniárias e não pecuniárias. As pecuniárias seriam aquelas que passam pelo sistema de preços; por exemplo, quando uma empresa, ao instalar uma nova fábrica em uma região faz com que o preço dos aluguéis de terrenos industriais aumente. Este aumento dos preços dos aluguéis é uma externalidade negativa para as empresas já instaladas. A externalidade pecuniária não representa uma falha de mercado, ou seja, uma concessão não ótima de recursos. Esta externalidade traz um aviso de preços para as empresas que podem arbitrar a satisfação de suas necessidades de terreno. Já Pearce (1976) propõe a distinção entre externalidades estáticas e externalidades dinâmicas. As estáticas são específicas e localizadas e apenas a internalização pelos agentes econômicos soluciona o problema. Já as dinâmicas resultam em efeitos ecológicos prolongados sobre o meio ambiente - como, por exemplo, alteração da camada de ozônio, aumento do efeito estufa - e são caracterizadas pelo caráter global que assumem, assim como pela irreversibilidade, incerteza e complexidade.

Baumol e Oates (1988) propõem dois outros grupos de externalidades: as públicas e as privadas. Externalidades públicas são aquelas ligadas a recursos não esgotáveis. Neste caso, quando este tipo de externalidade está presente, o fato de haver aumento ou queda no consumo do bem por um indivíduo não altera a disponibilidade deste bem para outros indivíduos. Exemplos deste tipo de externalidade: supondo uma cidade cujo ar esteja altamente poluído; um indivíduo respirando este ar não diminui a oferta de ar poluído para outros indivíduos morando na mesma cidade. Este é um exemplo de uma externalidade 
pública negativa. Outro exemplo, mas de uma externalidade pública positiva: a visão de um jardim bonito que confere benefícios a todos que desejarem apreciar a bela visão do jardim. $\mathrm{O}$ "consumo" da visão do jardim pelo individuo A não reduz a oferta disponível de visão do jardim para o indivíduo B (assumindo por hipótese que o exemplo não considera um número tão grande de admiradores do jardim que chega a causar congestionamento em sua apreciação). Externalidades privadas são associadas a recursos esgotáveis. Neste caso, o consumo de um bem reduz a disponibilidade deste bem para outros. Um exemplo deste tipo de externalidade: após a Segunda Guerra Mundial, em razão da escassez de combustível, em muitas áreas da Europa pessoas andavam ao longo das ferrovias procurando por carvão que tivesse caído dos trens. Cada pedaço de carvão encontrado por um indivíduo diminuía a oferta de carvão que poderia ser obtida por outro indivíduo que estivesse também passando pela ferrovia em busca do mesmo bem. Esta tipologia de externalidades é necessária porque o conjunto de incentivos e políticas públicas deve ser adaptado para cada tipo de externalidade (BAUMOL, OATES, 1988).

O quadro abaixo sintetiza os tipos de externalidades apresentadas acima:

Quadro 1: Alguns tipos de externalidades

\begin{tabular}{|l|l|l|}
\hline Autores & Tipos de externalidades & Descrição \\
\hline $\begin{array}{l}\text { Buchanan (1969) e Meade } \\
(1952,1973)\end{array}$ & Pecuniárias e não pecuniárias & $\begin{array}{l}\text { Pecuniárias passam pelo } \\
\text { sistema de preços. }\end{array}$ \\
\hline Pearce (1976) & Estáticas e dinâmicas & $\begin{array}{l}\text { Estáticas são específicas e } \\
\text { localizadas e dinâmicas } \\
\text { têm caráter global. }\end{array}$ \\
\hline Baumol e Oates (1988) & Públicas e privadas & $\begin{array}{l}\text { Públicas estão } \\
\text { relacionadas a recursos } \\
\text { não esgotáveis e privadas, } \\
\text { a recursos esgotáveis. }\end{array}$ \\
\hline
\end{tabular}

Fonte: Elaboração própria

$* * *$

Cabe aqui fazer uma distinção entre bens públicos e bens privados. Bens podem ser distribuídos ao longo de uma escala que tem em seus dois extremos opostos bens privados puros e bens públicos puros. Os bens privados podem ser divididos entre os indivíduos e alocados pelos mecanismos de mercados de maneira eficiente. Bens privados possuem duas características definidoras: exclusão e rivalidade (ou subtração) no consumo. Quando um bem privado é consumido por um indivíduo não pode ser consumido por outro. Assim, uma condição importante para os bens privados é assegurar a transferência dos direitos de 
propriedade. Já os bens públicos puros não podem ser divididos entre os indivíduos porque não há rivalidade (subtração) e nem exclusão no gozo de seus benefícios (o gozo do benefício por parte de um indivíduo não reduz a possibilidade de gozo por parte de outro). Portanto, as características dos bens públicos puros são a não exclusão e não rivalidade no consumo. Poucos bens são públicos ou privados puros. Bens que apenas parcialmente aderem aos critérios de públicos ou privados puros são chamados de "bens públicos impuros". Bens públicos impuros podem ser considerados em duas categorias: (i) bens que não possuem rivalidade no consumo, mas são excludentes - os chamados bens de clube (club goods ou toll goods); e (ii) bens que são não excludentes, mas apresentam rivalidade no consumo - os chamados recursos comuns, ou Common Pool Resources (CORNES, SANDLER, 1996).

A figura abaixo ilustra a classificação geral de tipos de bens:

Figura 5: Classificação geral de tipos de bens

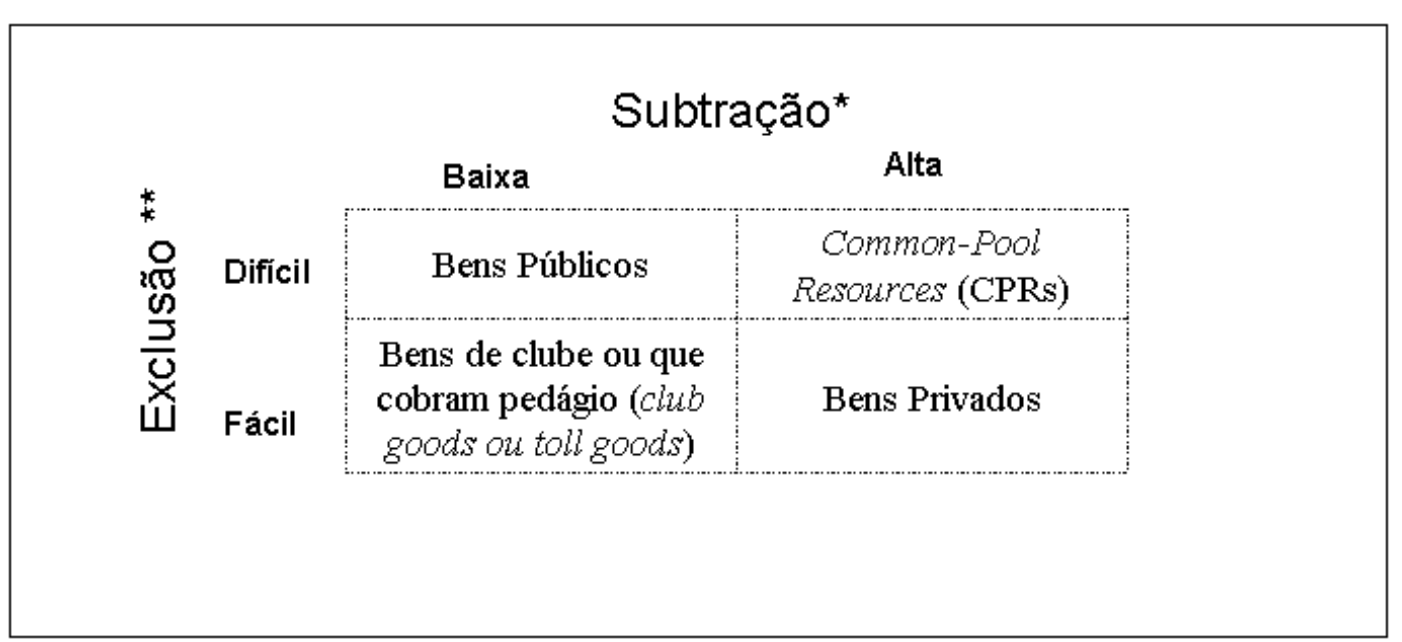

Fonte: Adaptado de Ostrom, Gardner, Walker, 1994, p.7

Onde:

(*) Subtração: bens variam em função do grau de subtração da disponibilidade do bem para outros pelo uso do bem por um indivíduo; (**) Exclusão: bens variam em função do grau de dificuldade em excluir ou limitar os potenciais beneficiários/ usuários do consumo destes bens que são ofertados pela natureza ou são resultado das atividades de outros indivíduos. Quanto mais difícil for excluir ou limitar potenciais beneficiários ou usuários, mais custoso é (OSTROM, GARDNER, WALKER, 1994). 
Assim, há um tipo particular de externalidades: o caso de recursos de uso comum (CommonPool Resources), a chamada "tragédia dos comuns".

O termo Common-Pool Resources (CPRs) trata de sistemas de recursos de forma independente dos direitos de propriedade envolvidos. Assim, no conjunto de CPRs estão incluídos recursos naturais ou construídos pelo homem em que a exclusão de beneficiários por meios físicos ou institucionais é altamente custosa e a exploração do uso destes recursos por uns reduz a disponibilidade dos recursos para outros. Estas duas características, a dificuldade para exclusão e a redução da disponibilidade do recurso para outros em razão do consumo de uns criam potenciais dilemas em que pessoas buscando seus interesses de curtoprazo produzem resultados de longo prazo insatisfatórios para todos. Para resolver este dilema é necessário restringir o acesso aos recursos e criar incentivos para os usuários investirem no recurso ao invés de sobre explorá-lo (OSTROM, GARDNER, WALKER, 1994).

Desde a publicação do artigo de Hardin, a expressão "tragédia dos comuns" simboliza a degradação esperada do meio ambiente quando muitos indivíduos têm acesso comum a recursos escassos (OSTROM, 2008).

A tragédia dos comuns trata da racionalidade da escolha individual resultando em colapso coletivo (ou irracionalidade coletiva). Garrett Hardin (1968) demonstra este ponto ao exemplificar o problema de um pasto "aberto a todos". É esperado que cada dono de gado queira colocar a maior quantidade de gado possível dentro do pasto comum; cada dono de gado procura maximizar sua função utilidade ao se perguntar "qual a utilidade para mim de adicionar um animal ao meu rebanho"? Há dois aspectos nesta análise: o primeiro é que o dono do gado se apropria do benefício de ter mais um animal seu no pasto comum (e assim pensam todos os donos de gado que consideram adicionar um animal ao rebanho que pastoreia na área comum). Mas os custos ou prejuízos causados pelo excesso de animais no pasto serão distribuídos com todos os outros donos de gado. Estes dois aspectos levam à escolha racional de cada dono de gado a adicionar continuamente animais ao rebanho. E aí reside a tragédia: "cada indivíduo está preso em um sistema que o compele a aumentar seu rebanho sem limites, em um mundo que é limitado" (HARDIN, 1968, p.1244) Assim, Hardin argumenta que a ruína é o destino de todos os homens, cada um perseguindo seu autointeresse em uma sociedade que acredita na liberdade dos recursos de uso comum (HARDIN, 1968). 
Segundo Ostrom (2008), uma década depois deste artigo seminal, Hardin concluiu que a solução para a tragédia dos comuns é ou um sistema privado ou o socialismo.

Assim, aqueles que fazem uso de recursos de uso comum demandam o recurso até que benefícios associados às suas ações se igualem aos custos. Mas porque cada indivíduo ignora os custos que impõe a outros, as decisões individuais levam à exaustão, ao sobreuso (OSTROM et al, 1999). Na essência da tragédia, está a ideia de free-riding (ou efeito carona): um indivíduo não se motiva a contribuir para o esforço conjunto, mas a pegar carona no esforço dos outros, sempre que não puder ser excluído dos benefícios que outros geram (OSTROM, 2008).

Os conceitos lançados por Hardin têm servido de base para subsidiar controle governamental imposto sobre os usuários de recursos comuns. Mas, se ao longo dos séculos, tragédias de uso comum têm acontecido repetidamente, por outro lado, usuários de recursos comuns também têm se auto-organizado para gerenciar o acesso a estes recursos, mantendo a visão da sustentabilidade (Ostrom et al, 1999; Ostrom, 2008). A questão que emerge quando se trata da tragédia dos comuns é como fazer com que os indivíduos persigam o bem-estar conjunto (ao invés do bem-estar individual), por meio da ação coletiva, evitando assim a tragédia dos comuns quando na presença de recursos de uso comum (OSTROM, 2008). 


\subsubsection{Soluções para o problema de externalidades negativas}

A construção de uma sociedade sustentável passa pelo debate sobre as externalidades negativas. Em diversos setores econômicos, as externalidades negativas tipicamente não estão refletidas nos custos privados, reduzindo, portanto, os incentivos para a realização de investimentos em produtos e serviços sustentáveis. A questão dos resíduos sólidos urbanos é um exemplo: de maneira geral, os custos totais associados ao pós-consumo de um determinado produto e sua embalagem não estão refletidos no custo total do produto (UNEP, 2011).

Um número extenso de políticas foram desenhadas e implantadas para corrigir problemas de externalidades negativas e limitar a produção e o uso de bens e produtos a elas associados. Dependendo das circunstâncias, tais políticas podem considerar limitação aos direitos de comercialização dos bens e produtos, impostos e subsídios, negociações bilaterais, banimento absoluto do bem ou produto. Políticas ligadas a restrições a consumos de narcóticos, álcool, combustíveis fósseis, uso de produtos florestais, presas de elefantes, chifres de rinocerontes, entre outros, são exemplos de correção de externalidades (CHIMELI, BoYD, 2010).

De maneira geral, a teoria econômica considera as seguintes soluções para o problema das externalidades (Mishan, 1971; RANDALL, 1971; CHIMELI E BOYD, 2010; UNEP, 2011):

- Proibição absoluta da produção da externalidade em questão, como, por exemplo, proibição absoluta de produção de um determinado poluente que imponha perdas a terceiros. Esta solução nem sempre é viável, porque muitas vezes o necessário não é abolir completamente qualquer traço do poluente em questão, mas mantê-lo em níveis aceitáveis; também, a abolição total do poluente pode ter um custo proibitivo. Ainda, algumas vezes o banimento de um determinado produto aumenta a produção de outro bem ou serviço também associado à externalidade negativa, como, por exemplo, o caso da proibição de colheita e comercialização do mogno brasileiro, que levou a um aumento dramático do comércio ilegal de mogno, inclusive via canais legítimos;

- Solução fiscal (imposto ou subsídio); impostos tendem a gerar incentivos para se reduzir emissões, fazer uso mais eficiente dos recursos naturais e estimular inovações. Impostos de cunho ambiental podem ser normalmente classificados em "poluidor pagador" - cujo objetivo é cobrar do poluidor pela poluição que causa - e "usuário 
pagador" - cujo objetivo é cobrar pela extração e uso dos recursos naturais. Os principais obstáculos à implantação desta solução são os custos de obter todas as informações necessárias e os custos de supervisão da solução; esta solução pode levar também à "sobre-correção" do problema. Impostos fixam um preço para a poluição e permitem que o mercado determine o nível ótimo de poluição.

- Regulação, solução que requer a mesma quantidade de informações que a solução fiscal, além dos custos para monitoramento do cumprimento da legislação, especialmente para o caso de regulações que são desenhadas para diferentes áreas, circunstâncias e momentos;

- Acordos voluntários, para o caso em que os custos de transação sejam nulos ou muito baixos, resultando, assim, em acordos mutuamente satisfatórios entre o gerador da externalidade negativa e o receptor da externalidade. Entretanto, se tais acordos não forem realizados entre firmas ou indústrias (e suportados por sanções legais) os custos de transação tendem a ser tão altos para negociar e manter os acordos que esta solução torna-se inviável;

- Instrumentos preventivos, com um pouco de cada uma das formas descritas anteriormente, considerando ações governamentais e acordos voluntários ou mesmo a criação de um sistema de padrões suportados por ameaças de multas ou encarceramento para os desobedientes;

- Solução de mercado, ou seja, a criação de mercados para os bens. As soluções de mercado baseiam-se no pressuposto de que as partes interessadas tenderão a buscar realizar potenciais ganhos no mercado; para tanto, é necessário haver direitos de propriedade claramente definidos; assim, nesta solução, o próprio mercado estabeleceria o volume de externalidades aceitáveis, assim como os preços aplicáveis. Ao contrário dos impostos, onde o preço pela poluição é fixo e a determinação do nível ótimo de poluição é estabelecido pelo mercado, nas soluções de mercado como sistemas cap-and-trade, comercialização de licenças, etc, os níveis de poluição são $a$ priori fixos e os preços determinados pelo mercado.

A seguir são apresentadas considerações sobre uma das mais importantes externalidades negativas associadas ao mundo contemporâneo: a degradação dos serviços ecossistêmicos. 


\subsubsection{Serviços Ecossistêmicos}

Serviços ecossistêmicos são as condições e os processos pelos quais os ecossistemas naturais e as espécies que os compõem sustentam a vida humana. Eles mantêm a biodiversidade e a produção de produtos ecossistêmicos, tais como a alimentos que vêm do mar, madeira, biocombustíveis, fibras naturais, matérias-primas industriais e farmacêuticas e seus precursores. A colheita e comércio destes produtos representam uma parte importante e familiar das atividades econômicas. Além da produção destes produtos, os serviços ecossistêmicos exercem funções de suporte à vida, como limpeza, reciclagem, renovação e geram diversos benefícios estéticos e culturais intangíveis. Os serviços ecossistêmicos incluem purificação do ar e da água, mitigação de secas e inundações, desintoxicação e decomposição de resíduos, geração e renovação de solo e fertilidade de solo, polinização de culturas e vegetação natural, controle da maior parte de pestes agrícolas, dispersão de sementes e deslocamento de nutrientes, manutenção da biodiversidade, proteção dos raios solares danosos, estabilização parcial do clima, moderação das temperaturas extremas, da força dos ventos e das ondas, suporte às diversas culturas humanas, provisão de beleza

estética e estímulo intelectual que elevam o espírito humano. Para cada um dos serviços listados, há inúmeras espécies necessárias para que estes serviços sejam desempenhados (DAILY, 1997).

O quadro abaixo apresenta tipologia e exemplos de serviços:

Quadro 2 : Tipologia e exemplos de serviços ecossistêmicos

\begin{tabular}{|l|}
\hline \multicolumn{1}{|c|}{ Tipologia e exemplos de serviços ecossistêmicos } \\
\hline I. $\quad$ Produção de bens \\
\hline a. $\quad$ Alimentos \\
\hline Produtos de fauna e flora terrestre \\
\hline Forragem \\
\hline Alimentos do mar (seafood) \\
\hline Especiarias \\
\hline b. Farmacêuticos \\
\hline Produtos Medicinais \\
\hline Precursores de produtos farmacêuticos sintéticos \\
\hline c. $\quad$ Materiais Duráveis \\
\hline Fibras naturais \\
\hline Madeira \\
\hline
\end{tabular}




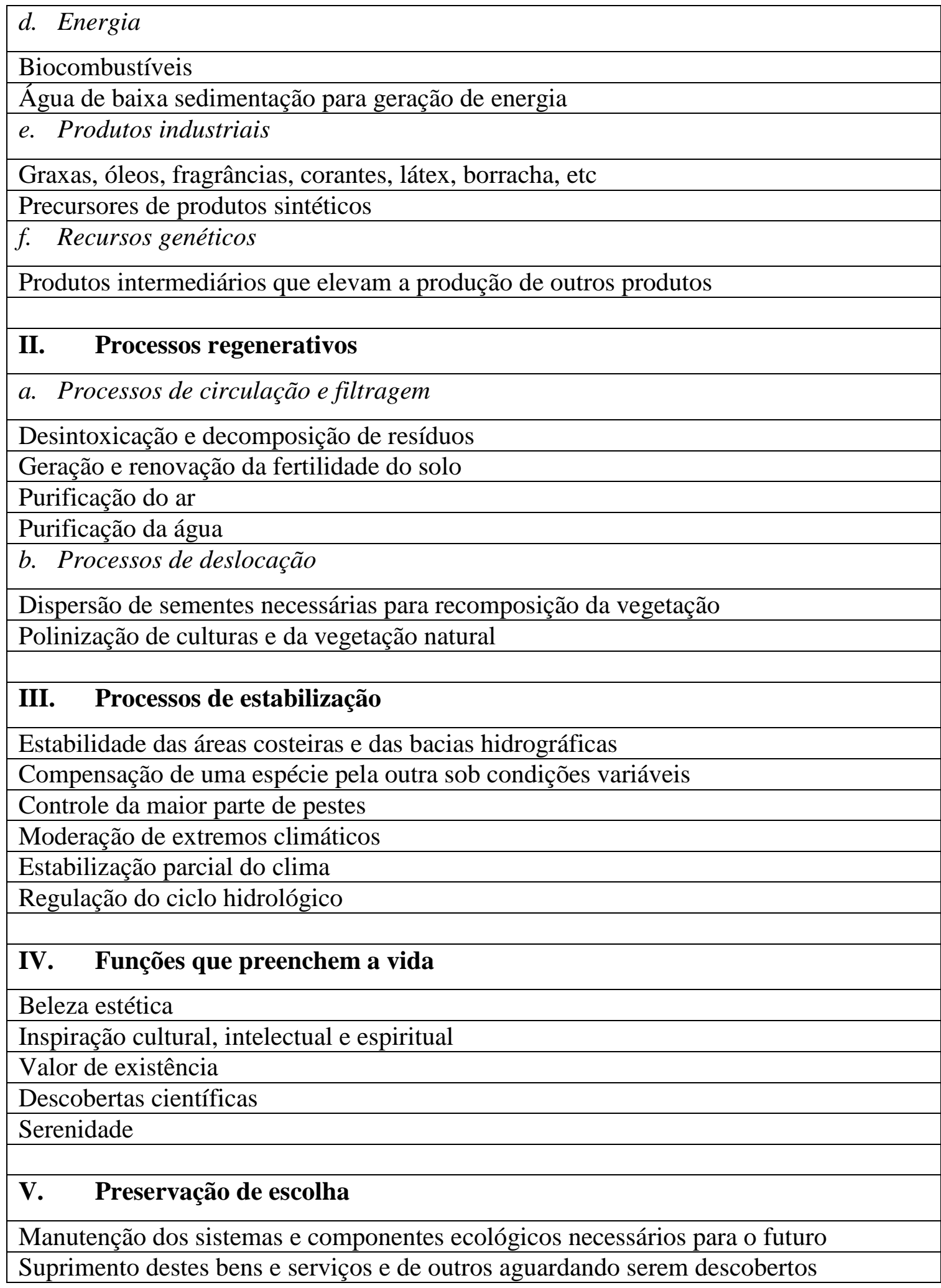

Fonte: Autora; Adaptado de Daily, 1999

Os serviços ecossistêmicos são responsáveis, entre outros, por prover segurança alimentar, suprimento de água doce, proteção contra eventos climáticos extremos, fontes para indústria de remédios, recreação, polinização, estoque de carbono, prevenção de erosão, entre outros. 
Entretanto, a humanidade vive hoje acima da capacidade de suporte do planeta e, como consequência, mais de $60 \%$ dos serviços ecossistêmicos e a biodiversidade que contêm estão degradados, comprometendo a sustentabilidade, o bem-estar, a saúde e segurança das sociedades humanas. A degradação ambiental causa o aumento dos impactos de desastres naturais como inundações e secas, afetando anualmente as vidas de 270 milhões de pessoas no mundo todo e causando a morte de mais de 100.000 por ano. A degradação e poluição dos ecossistemas estão entre as principais causas de falta de acesso à água potável para 900 milhões de pessoas. Adicionalmente, a perda de ecossistemas pode resultar na redução da produção de alimentos em cerca de 25\% em 2050 (Nellemann, CORCORAN, 2010; LOVINS, LOVINS, HAWKEN, 2000; COSTANZA et al, 1987).

O valor dos serviços ecossistêmicos não é capturado pelos mercados ou quantificado adequadamente de forma que seja comparável aos serviços econômicos e ao capital manufaturado. É, portanto, negligenciado e esta negligência pode comprometer a sustentabilidade dos seres humanos na biosfera. Estes serviços não capturados representam falhas de mercados que ocorrem, principalmente por duas razões. Em primeiro lugar, os serviços ecossistêmicos não têm direitos de propriedade claramente definidos. Como ninguém é dono do serviço ou tem direitos prioritários sobre estes serviços, e outros não podem ser excluídos dos seus benefícios, há poucos incentivos para a gestão sustentável destes recursos. Em segundo lugar, em muitos casos, os custos de monitoramento e negociação seriam muito altos. Exemplo: os casos de transações que envolvem atividades econômicas que são afetadas por interações ecológicas envolvendo distâncias geográficas longas - como os efeitos da deflorestação a montante podem afetar atividades a quilômetros de distância a jusante - ou envolvendo distâncias temporais grandes - como a questão das mudanças climáticas, em que emissões hoje podem comprometer as futuras gerações. É importante ressaltar que falhas de mercado envolvem não somente alocação equivocada de recursos no presente, mas também alocação equivocada de recursos ao longo do tempo. Como decorrência da baixa precificação de serviços ecossistêmicos (ou não precificação), não há incentivos para o desenvolvimento de tecnologias que economizem o uso destes serviços, direcionando, portanto, a mudança tecnológica no sentido contrário ao da conservação (COSTANZA et al, 1987).

O desafio é integrar os serviços ecossistêmicos às decisões reais. Para que isso seja possível, é preciso entender as conexões, a produção conjunta de serviços, quantificação da quantidade de benefícios derivados dos serviços para vários segmentos da sociedade; compreensão acerca 
dos processos de decisão dos indivíduos, corporações e governos; integrar pesquisa com desenhos institucionais e implementações de políticas; e formular intervenções políticas que são desenhadas para favorecer, com o tempo, aprendizado e evolução. A figura abaixo ilustra a relação entre serviços ecossistêmicos e processos decisórios (DAILY et al, 2011):

Figura 6: Esquema relacionando serviços ecossistêmicos e processos decisórios

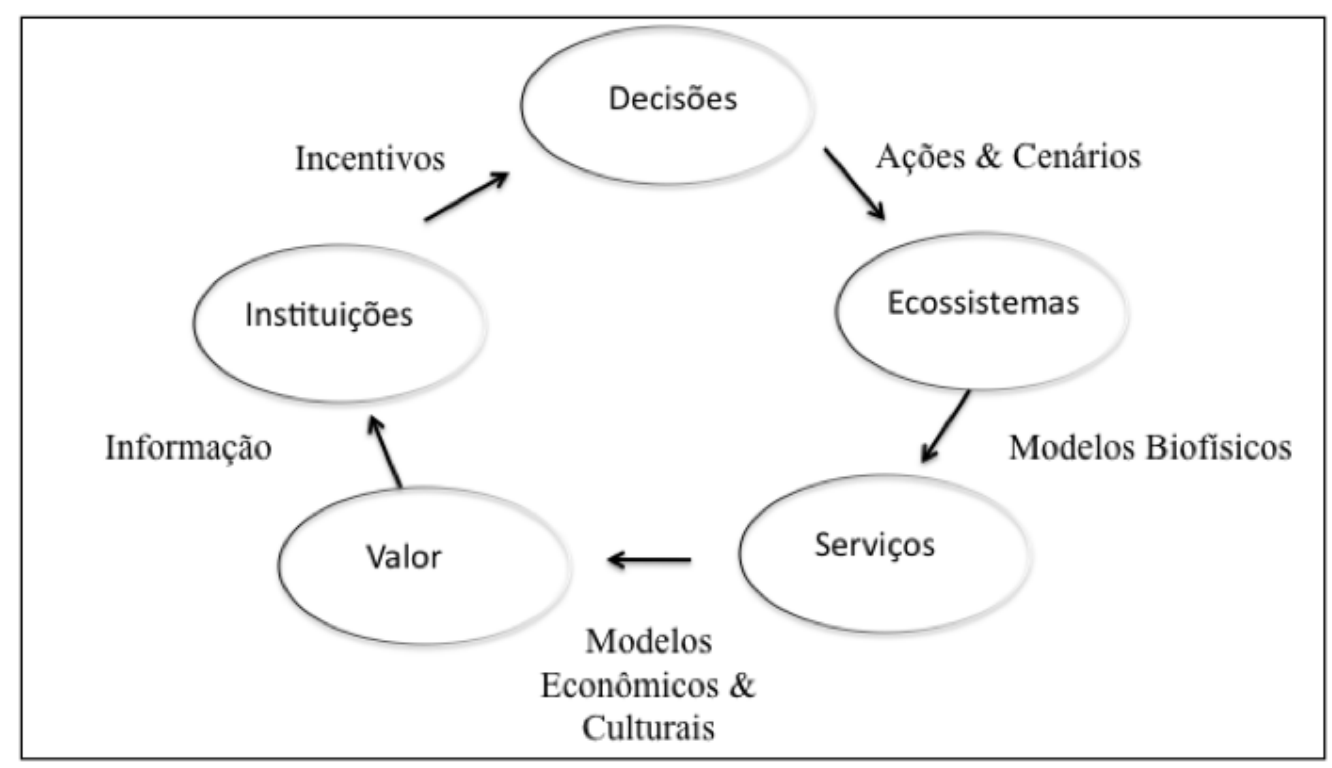

Fonte: Daily et al, 2009 apud KAREIVA et al, 2011

Decisões levam a ações, que por sua vez, estão profundamente relacionadas com o uso ou conservação de ecossistemas. Por esta razão, é fundamental destacar as conexões entre as ações decorrentes de quaisquer decisões. As ciências biofísicas colaboram para a compreensão do impacto das ações sobre os ecossistemas. E, adicionando a contribuição das ciências econômicas e demais ciências sociais, a ciência contribui para a compreensão acerca de como se dá a relação entre as ações tomadas, os ecossistemas e os serviços que estes prestam para o bem-estar humano e do mundo natural. As ciências sociais contribuem também para a compreensão dos valores que os serviços ecossistêmicos têm para as pessoas. As técnicas de valoração econômica dos serviços ecossistêmicos podem ser utilizadas para estabelecer esta relação, ao atribuir valor monetário ao capital natural. Como o valor dos serviços ecossistêmicos não é totalmente capturado em termos monetários, torna-se fundamental caracterizar valor em suas múltiplas dimensões, incluindo, por exemplo, saúde, suporte à sobrevivência, importância cultural, entre outras dimensões. Isso fará com que a avaliação seja ampla o suficiente para incluir todos os benefícios dos serviços ecossistêmicos 
- monetários ou não - percebidos pelas pessoas. E por fim, as informações de valores podem gerar informações relevantes para o molde de instituições - tais como mercados, subsídios, políticas de uso da terra, atuação de ONGs dedicadas à conservação entre outros - para guiar a gestão e formulação de políticas envolvendo recursos naturais. As instituições adequadas podem, por sua vez, criar os incentivos necessários para que indivíduos, comunidades, corporações e governos tomem decisões baseadas em valores compartilhados (DAILY et al, 2011).

$* * *$

No sentido de contribuir para que a importância e o valor dos serviços ecossistêmicos sejam percebidos pela sociedade e incorporados no processo de formulação de políticas públicas e das estratégias empresariais, algumas iniciativas importantes que visam avaliar o estado destes serviços e sua valoração vêm ocorrendo, e por decorrência, estão surgindo mercados envolvendo alguns tipos de serviços ecossistêmicos.

A inclusão do valor dos serviços ecossistêmicos nos processos de decisão de governos, corporações, culturas tradicionais e indivíduos não substitui ou enfraquece o valor intrínseco da natureza, nem o imperativo moral de conservá-la. A valoração de serviços ecossistêmicos e do capital natural complementa estas preocupações morais, ampliando nossa compreensão dos papéis que a natureza desempenha em nossa vida e as razões para conservá-la para além do argumento ético e moral. A valoração é um meio para se avaliar políticas e decisões alternativas e/ou atividades humanas. Sem as ferramentas de avaliação, os serviços ecossistêmicos são sistematicamente ignorados por governos, empresas, sociedade civil e como resultado, as perdas do capital natural e da biodiversidade são maciças (DAILY et al, 2011).

Entre as iniciativas mais importantes na avaliação da importância e valoração de serviços ecossistêmicos, destacam-se o Millennium Ecosystem Assessment (MEA) e o estudo The Economics of Ecosystems and Biodiversity (TEEB). Estas duas iniciativas são apresentadas de maneira sucinta para respeitar o escopo desta tese.

A Avaliação Ecossistêmica do Milênio (MEA, na sigla em inglês) foi criada em 2000 pelo Programa para o Meio Ambiente das Nações Unidas (UNEP, na sigla em inglês) e realizada 
no período de 2001 a 2005, e teve por objetivo avaliar as consequências de mudanças nos ecossistemas para o bem-estar humano e as bases científicas que justificam os esforços de conservação destes ecossistemas. O MEA dividiu os serviços ecossistêmicos em quatro grupos: (i) serviços de provisão, que são aqueles relacionados com a capacidade dos ecossistemas em prover bens, sejam eles alimentos (frutos, raízes, pescado, caça, mel); matéria-prima para a geração de energia (lenha, carvão, resíduos, óleos); fibras (madeiras, cordas, têxteis); fitofármacos; recursos genéticos e bioquímicos; plantas ornamentais e água; (ii) serviços reguladores, que são os benefícios obtidos a partir de processos naturais que regulam as condições ambientais que sustentam a vida humana, como a purificação do ar, regulação do clima, purificação e regulação dos ciclos das águas, controle de enchentes e de erosão, tratamento de resíduos, desintoxicação e controle de pragas e doenças; (iii) serviços culturais, que estão relacionados com a importância dos ecossistemas em oferecer benefícios recreacionais, educacionais, estéticos e espirituais; e (iv) serviços de suporte, que são os processos naturais necessários para que os outros serviços existam, como a ciclagem de nutrientes, a produção primária, a formação de solos, a polinização e a dispersão de sementes (MEA, 2005; GUEDES, SEEHUSEN, 2011).

O estudo foi conduzido pela Organização das Nações Unidas, governado por um painel multistakeholder que incluiu representantes de instituições internacionais, governos, negócios, ONGs, povos indígenas, universidades. Baseado na contribuição de 1.360 especialistas, seus resultados foram publicados em cinco volumes técnicos, apresentando o estado atual e a tendência futura dos serviços ecossistêmicos e as opções para restaurar, conservar e melhorar o uso sustentável destes ecossistemas. As principais conclusões do MEA jogam luz sobre o estado do mundo em termos de conservação e depleção dos serviços ecossistêmicos. As principais conclusões do estudo apontam que:

- Nos últimos 50 anos, os seres humanos mudaram os ecossistemas mais rapidamente e de maneira mais extensa que em qualquer outro período da história humana. E isto aconteceu por causa da demanda crescente por alimentos, água potável, madeira, fibras e combustível. O estudo concluiu que 15 dos 24 serviços ecossistêmicos examinados durante a pesquisa estavam degradados ou sendo utilizados de maneira insustentável, tais como captação e uso de água potável, captura de peixes, purificação da água e do ar, regulação do clima, entre outros. E embora os custos totais da perda e degradação destes serviços ecossistêmicos sejam difíceis de mensurar, as evidências 
apontam que estes custos são substanciais e crescentes. E a degradação destes serviços acontece como consequência das ações tomadas no sentido de aumentar a oferta de outros serviços, como oferta de comida, por exemplo;

- As alterações impostas sobre os serviços ecossistêmicos geraram impactos positivos sobre o bem-estar humano e o desenvolvimento econômico, mas estes ganhos foram obtidos a partir de custos crescentes na forma de degradação dos serviços ecossistêmicos, aumento de riscos de mudanças não lineares e exacerbação da pobreza para alguns grupos populacionais. A não ser que estes problemas sejam solucionados, os benefícios gerados pela degradação dos ecossistemas serão substancialmente menores para as gerações futuras. Há uma imensa inequidade na distribuição dos custos relacionados à degradação dos serviços ecossistêmicos, já que pobres tendem a sofrer mais as consequências da degradação ambiental;

- A degradação dos ecossistemas pode crescer significativamente na primeira metade do século XXI. (MEA, 2005)

O The Economics of Ecosystems and Biodiversity - TEEB é um estudo também conduzido pelo Programa Ambiental das Nações Unidas e tem sua origem na reunião dos ministros de meio ambiente do grupo das oito economias mais industrializadas ${ }^{3}$ e das cinco maiores economias em processo de industrialização ${ }^{4}$ em Potsdam, Alemanha, em 2007. O propósito do estudo é analisar os benefícios econômicos globais da diversidade biológica, os custos da perda da biodiversidade e as falhas das medidas de proteção versus os custos da sua efetiva conservação. E tem por objetivo último fornecer inputs para que os valores do capital natural, bem como os serviços ecossistêmicos fornecidos por este capital, estejam refletidos nos processos de tomada de decisão. A invisibilidade da contribuição econômica destes serviços contribui para que sejam desconsiderados nos processos de formulação das políticas públicas e das estratégias corporativas. Ao contribuir para a valoração de alguns destes serviços, o TEEB pretende contribuir para destacar a importância do capital natural para os processos econômicos. O público-alvo do estudo são os tomadores de decisão nos níveis nacional e local, o setor de negócios e o público em geral. O TEEB é subdividido em TEEB Mudanças do Clima, TEEB Bases Econômicas e Ecológicas, TEEB para formuladores de políticas nacionais e internacionais, TEEB para formuladores de políticas regionais e locais, TEEB para o setor de negócios (TEEB, 2010).

\footnotetext{
${ }^{3}$ O G8 é composto de Estados Unidos, Japão, Alemanha, Reino Unido, França, Itália, Canadá e Rússia.

${ }^{4}$ Brasil, China, Índia, México e África do Sul. (TEEB, 2010)
} 
Estas iniciativas refletem o momento atual em que muito se discute - tanto em âmbito público como privado - a importância de se dar visibilidade à contribuição dos serviços prestados pelos ecossistemas para os processos econômicos e para o desenvolvimento e manutenção das diversas formas de vida. Como grande parte destes serviços não é considerada pelos sistemas de preços e pelos mecanismos de mercado, configuram-se como externalidades. Neste sentido, o World Resources Institute (WRI) desenvolveu um método que visa identificar e priorizar os impactos e demandas das organizações privadas sobre os serviços ecossistêmicos. A degradação dos ecossistemas tem impactos relevantes para o ambiente de negócios. Isto porque as empresas não apenas impactam os ecossistemas e os serviços que estes prestam, como também demandam serviços ecossistêmicos, dependendo, portanto, de seu bom financiamento para o desempenho de suas atividades produtivas. Portanto, a degradação dos ecossistemas impõe riscos e oferece oportunidades de negócios de diversas naturezas para as organizações (HANSON et al, 2012).

O quadro abaixo relaciona alguns destes potenciais riscos e oportunidades: 
Quadro 3: Potenciais fontes de riscos e oportunidades oriundos de serviços ecossistêmicos:

\begin{tabular}{|c|c|c|}
\hline $\begin{array}{l}\text { Tipos de } \\
\text { risco/oportunidade }\end{array}$ & $\begin{array}{l}\text { Exemplos de fontes de } \\
\text { riscos }\end{array}$ & $\begin{array}{l}\text { Exemplos de fontes de } \\
\text { oportunidades }\end{array}$ \\
\hline Operacionais & $\begin{array}{l}\text { - Riscos oriundos de alta de } \\
\text { preços de recursos naturais } \\
\text { (água, por exemplo), em } \\
\text { função de sua crescente } \\
\text { escassez; } \\
\text { - Riscos de falta de oferta } \\
\text { do recurso natural em } \\
\text { função de sua escassez, } \\
\text { como, por exemplo, menor } \\
\text { produção em usinas } \\
\text { hidrelétricas em razão de } \\
\text { mês chuvas ou secas } \\
\text { prolongadas; } \\
\text { - Danos a negócios em } \\
\text { zonas costeiras em razão } \\
\text { de inundações; }\end{array}$ & $\begin{array}{l}\text { - Aumento na eficiência no } \\
\text { uso de água; }\end{array}$ \\
\hline Legais / Regulatórios & $\begin{array}{l}\text { - Riscos de novas multas, } \\
\text { taxas, regulações } \\
\text { governamentais, ou ações } \\
\text { judiciais de comunidades } \\
\text { que tiveram a provisão de } \\
\text { serviços ecossistêmicos } \\
\text { prejudicada por atividades } \\
\text { corporativas; }\end{array}$ & $\begin{array}{l}\text { - Engajamento de governos } \\
\text { para o desenvolvimento de } \\
\text { políticas e incentivos que } \\
\text { visem à proteção ou } \\
\text { restauração } \\
\text { ecossistemas necessários às } \\
\text { atividades da organização. }\end{array}$ \\
\hline Reputacionais & $\begin{array}{l}\text { - Empresas de varejo sendo } \\
\text { objeto de campanhas de } \\
\text { ONGs em função de } \\
\text { compras de madeira e } \\
\text { papel oriundos de } \\
\text { vegetações sensíveis ou }\end{array}$ & $\begin{array}{l}\text { - Implementação e } \\
\text { comunicação de práticas } \\
\text { sustentáveis de aquisição } \\
\text { de } \\
\text { investimentos, operações, } \\
\text { etc, como forma de }\end{array}$ \\
\hline
\end{tabular}




\begin{tabular}{|c|c|c|}
\hline & $\begin{array}{l}\text { bancos } \\
\text { protestos por viabilizar } \\
\text { atividades que degradam } \\
\text { ecossistemas; }\end{array}$ & diferenciar a organização; \\
\hline Mercado e Produto & $\begin{array}{l}\text { - Ativismo do consumidor } \\
\text { que dêem preferência a } \\
\text { produtos com menores } \\
\text { impactos ecossistêmicos ou } \\
\text { implantação pelo governo } \\
\text { de políticas de compras } \\
\text { baseadas em critérios de } \\
\text { sustentabilidade; }\end{array}$ & $\begin{array}{l}\text { - Lançamento de novos } \\
\text { produtos e serviços que } \\
\text { reduzam o impacto do } \\
\text { consumidor sobre os } \\
\text { ecossistemas, participando } \\
\text { em mercados emergentes } \\
\text { para proteção das bacias } \\
\text { hidrográficas e seqüestro } \\
\text { de carbono, capturando } \\
\text { fluxos de renda advindos } \\
\text { de ativos naturais de } \\
\text { propriedade } \\
\text { organização, oferecendo } \\
\text { madeira, frutos do mar, } \\
\text { entre outros, certificados; }\end{array}$ \\
\hline Financeiro & $\begin{array}{l}\text { - Implantação pelos bancos } \\
\text { de requerimentos para } \\
\text { empréstimo mais rígidos } \\
\text { por parte dos bancos; }\end{array}$ & $\begin{array}{l}\text { - Condições de crédito / } \\
\text { investimentos mais } \\
\text { atrativas para empresas } \\
\text { que ofereçam produtos ou } \\
\text { serviços que restaurem } \\
\text { ecossistemas degradados } \\
\text { ou melhorem a eficiência } \\
\text { no uso dos recursos } \\
\text { naturais. }\end{array}$ \\
\hline
\end{tabular}

Fonte: Adaptado de Hanson et al, 2012

Visando contribuir para que as organizações possam avaliar o impacto e a dependência que têm dos serviços ecossistêmicos, o World Resources Institute desenvolveu a ferramenta Ecosystem Services Review - ESR, definindo assim as etapas para identificação dos impactos e demandas da organização sobre os serviços ecossistêmicos: (i) seleção do escopo: seleção 
das fronteiras dentro das quais serão analisados os impactos e demandas da organização sobre os serviços ecossistêmicos; pode ser uma unidade de negócio, produto, um mercado, um grande fornecedor etc; (ii) identificação dos ecossistemas prioritários, buscando identificar quais são os mais relevantes para o desempenho corporativo; (iii) analisar e identificar tendências nos serviços prioritários, assim como eventuais forças que podem alavancar estas tendências; (iv) identificar riscos e oportunidades para os negócios resultantes da tendências nos serviços prioritários; e (v) desenvolver estratégias para gerenciar os riscos e as oportunidades identificadas, que podem ser simples mudanças internas - em seus processos produtivos, de comercialização de produtos, entre outros-, engajamento do setor e de stakeholders e engajamento de formuladores de políticas públicas (HANSON et al , 2012).

A figura abaixo ilustra as etapas do framework Ecosystem Services Review proposto pelo WRI: 
Figura 7: Framework para consideração dos serviços ecossistêmicos na estratégia corporativa:

\begin{tabular}{|c|c|c|c|c|c|}
\hline Etapas & 1. Definir escopo & $\begin{array}{l}\text { 2. Identificar } \\
\text { serviços } \\
\text { ecossistêmicos } \\
\text { prioritários }\end{array}$ & $\begin{array}{l}\text { 3. Analisar } \\
\text { tendências } \\
\text { para os } \\
\text { serviços } \\
\text { ecossistêmicos } \\
\text { prioritários }\end{array}$ & $\begin{array}{l}\text { 4. Identificar } \\
\text { riscos e } \\
\text { oportunidades } \\
\text { para os } \\
\text { negócios }\end{array}$ & $\begin{array}{l}\text { 5. Desenvolver } \\
\text { estratégias }\end{array}$ \\
\hline Consideraçōes & $\begin{array}{l}\text {-Quais etapas } \\
\text { da cadeia de } \\
\text { valor serão } \\
\text { consideradas? } \\
\text { - Dispersão } \\
\text { geográfica; } \\
\text { - Unidades de } \\
\text { negócios } \\
\text { consideradas. }\end{array}$ & $\begin{array}{l}\text {-Compreensão } \\
\text { dos níveis de } \\
\text { impacto e } \\
\text { demanda sobre } \\
\text { serviços } \\
\text { ecossistêmicos } \\
\text { para selecionar } \\
\text { os prioritários } \\
\text { para a } \\
\text { organização. }\end{array}$ & $\begin{array}{l}\text {-Análise das } \\
\text { tendências de } \\
\text { oferta e } \\
\text { demanda dos } \\
\text { serviços } \\
\text { priorizados; } \\
\text { - Quais } \\
\text { alavancas } \\
\text { diretas e } \\
\text { indiretas estão } \\
\text { relacionadas a } \\
\text { estas } \\
\text { tendências? }\end{array}$ & $\begin{array}{l}\text {-Alterações na } \\
\text { quantidade e } \\
\text { qualidade dos } \\
\text { serviços } \\
\text { ecossistêmicos } \\
\text { oferecem riscos e } \\
\text { oportunidades } \\
\text { para os negócios } \\
\text { de diversas } \\
\text { naturezas: } \\
\text { operacionais, } \\
\text { regulatórios e } \\
\text { legais, } \\
\text { reputacionais, de } \\
\text { mercado e } \\
\text { produto, } \\
\text { financeiros. }\end{array}$ & $\begin{array}{l}\text {-Formulação de } \\
\text { estratégias para } \\
\text { lidar com os riscos } \\
\text { e oportunidades } \\
\text { identificados no } \\
\text { passo anterior. } \\
\text { Estratégias podem } \\
\text { considerar } \\
\text { mudanças } \\
\text { internas, } \\
\text { engajamento de } \\
\text { stakeholders, } \\
\text { envolvimento em } \\
\text { formulação de } \\
\text { políticas públicas. }\end{array}$ \\
\hline
\end{tabular}

Fonte: Adaptado de Hanson et al, 2012

A etapa de identificação dos ecossistemas prioritários do método do WRI está baseada na identificação e avaliação qualitativa do grau de impacto e dependência da organização sobre os serviços ecossistêmicos, assim como a análise de substitutos que sejam eficientes em custo, seguindo o diagrama exposto na figura abaixo. 
Figura 8: Perguntas orientadoras para avaliar dependência dos serviços ecossistêmicos pela organização :

Perguntas orientadoras para avaliar dependência dos serviços ecossistêmicos

1. Este serviço ecossistêmico é um input e/ou serve como condição para o

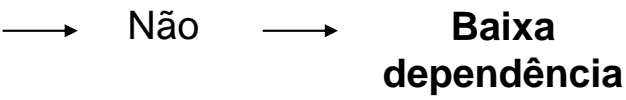

desempenho

organizacional?<smiles>[13CH2][13CH3]</smiles>

Sim<smiles>[13CH2][13CH3]</smiles>

2. Este serviço

ecossistêmico tem

substitutos que sejam eficientes em custo?

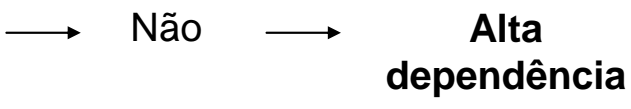

Sim<smiles>[13CH2][13CH3]</smiles>

Média dependência

Fonte: Adaptado de Hanson et al, 2012 
Figura 9: Perguntas orientadoras para avaliar impacto da organização sobre os serviços ecossistêmicos:

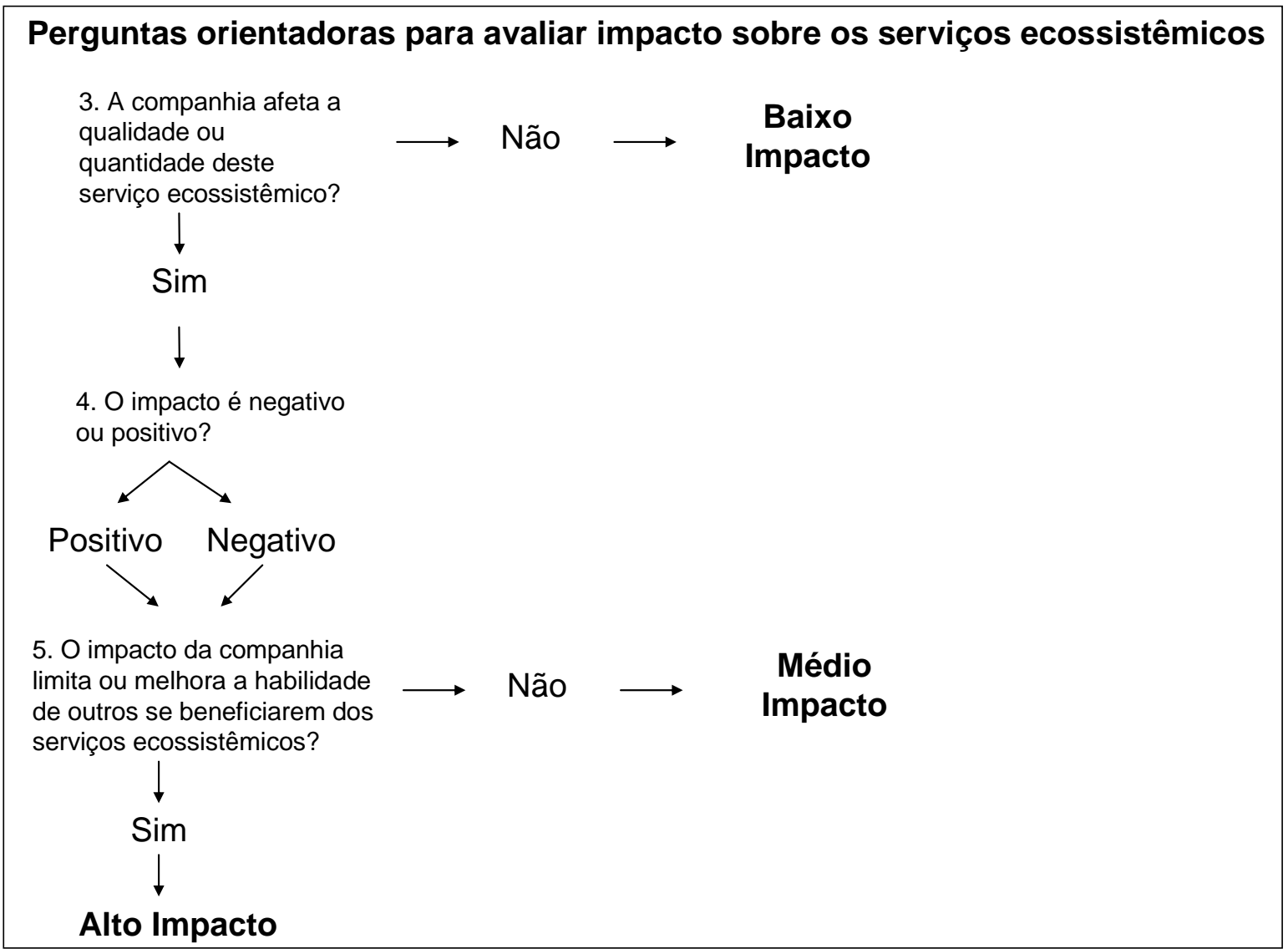

Fonte: Hanson et al, 2012

Como tentativas atuais de se internalizar o valor de alguns destes serviços ecossistêmicos, são apresentados dois tipos de iniciativas (altamente dependentes de regulação governamental) que estão amparadas na premissa de que é possível utilizar-se de iniciativas privadas visando incentivos econômicos para a conservação dos ecossistemas.

Os dois exemplos apresentados sucintamente abaixo são: Pagamentos por Serviços Ambientais (PSA) e Mercados de Carbono.

\subsubsection{Pagamentos por Serviços Ambientais (PSA)}

"Serviços ambientais são os serviços prestados pelos ecossistemas naturais e as espécies que os compõem, dando sustentação e preenchimento das condições para a permanência da vida humana na Terra.” (DAILY, 1997 apud VeigA; GAVAldẽo, 2010 p.3) Pagamento por serviços ambientais é um mecanismo que visa melhorar a provisão de serviços ambientais em que os fornecedores de serviços ambientais recebem pela conservação de áreas que provêm estes 
serviços e aqueles que se beneficiam dos serviços ambientais em questão pagam pela conservação. Os pagamentos são condicionais à conservação e a participação é voluntária. Exemplos de mecanismos de PSA existem na Colômbia, Costa Rica, Equador, El Salvador, México, África do Sul, Brasil (PAgiola, 2006; Guedes, Seehusen, 2011). A China investiu cerca de US\$ 100 bilhões em pagamentos por serviços ambientais no período de 1998 a 2010 (ZHANG et al. 2000 apud DAILY et al, 2011 ). Formalmente, pagamento por serviços ambientais é uma transação voluntária e condicional sobre serviços ambientais claramente definidos ou sobre usos de terras que provenham serviços ambientais envolvendo pelo menos um fornecedor e um usuário sob a condição de que o fornecedor garanta a provisão do serviço (WUNDER, 2005 apud WundER, ALBÁN, 2007).

Por estabelecer um mecanismo de estímulo à conservação, o PSA é um instrumento econômico atualmente bastante discutido para lidar com o problema do desinteresse dos agentes econômicos em atividades de conservação e uso sustentável dos recursos naturais. $\mathrm{O}$ instrumento é desenhado para recompensar aqueles que produzem ou mantêm os serviços ambientais e que não o fariam sem incentivo econômico; o incentivo melhora a rentabilidade das atividades de conservação, seguindo o princípio do protetor - recebedor. $\mathrm{O}$ fato de ser voluntário diferencia o PSA de instrumentos de comando e controle. Os serviços ambientais comercializados no mundo com maior frequência são: (i) carbono, onde se paga por tonelada de $\mathrm{CO}_{2}$ não emitido para atmosfera ou sequestrado; (ii) água, onde se paga pela manutenção ou aumento da quantidade e/ou qualidade de água; (iii) biodiversidade, paga-se pela proteção de espécies ou hectare de habitat protegido; (iv) beleza cênica, paga-se por serviços de turismo e permissões de fotografia (GuEdES, SEEHUSEN, 2011). Landell-Mills e Porras (2002) identificaram 72 esquemas de Pagamentos por Serviços Ambientais em operação no mundo. Nestes esquemas, ONGs, governos e empresas pagam pela conservação de serviços ecossistêmicos. No Brasil, foram identificados 79 projetos de PSA no bioma Mata Atlântica, sendo 33 projetos de PSA-carbono, 41 projetos de PSA-Água, 5 de PSA-Biodiversidade, distribuídos em diversos estados brasileiros (GUEDES, SEEHUSEN, 2011).

O PSA é um mecanismo que, embora ainda em desenvolvimento, sinaliza que mercados para conservação podem oferecer oportunidades para organizações, seja para fazerem offset de seus impactos ambientais (e reduzir risco estratégico) ou eventualmente se beneficiarem financeiramente dos incentivos disponíveis para a conservação. 


\subsubsection{Mercados de Carbono}

Emissões de gases de efeito estufa e seus impactos sobre as mudanças climáticas são uma das mais importantes externalidades atuais:

"Emissões de gases de efeito estufa são externalidades e representam a maior falha de mercado que o mundo já viu. Todos nós produzimos emissões, as pessoas ao redor do mundo já sofrem em função de emissões passadas e as emissões atuais têm o potencial de gerar impactos catastróficos no futuro. Portanto, estas emissões não são externalidades ordinárias e localizadas. A essência da questão é o risco em escala global." (STERN, 2008)

Os efeitos ligados às concentrações crescentes de gases de efeito estufa - como, por exemplo, o aumento da temperatura, mudanças no ciclo hidrológico, aumento do nível dos oceanos podem levar a uma série de efeitos econômicos adversos, incluindo (mas não se limitando a) redução da produção e da oferta de bens e serviços, tais como produtos agrícolas e florestais. Também, o aumento de eventos climáticos extremos como furacões, inundações e alagamentos podem causar danos materiais severos. As mudanças climáticas terão efeitos negativos sobre o bem-estar humano, na medida em que degradam os ecossistemas e a biodiversidade. Portanto, políticas para mitigar as emissões de GEE e limitar adições às já elevadas concentrações atuais de GEE se justificam do ponto de vista econômico porque contribuem para a não ocorrência dos efeitos econômicos adversos, embora tais políticas e suas medidas decorrentes impliquem em custos. Entretanto, a distribuição desigual dos custos e benefícios associados à mitigação das mudanças climáticas entre diferentes países e sociedades cria diferentes incentivos, dificultando a ação coletiva no sentido da mitigação das emissões. A questão das mudanças climáticas é, provavelmente, o maior desafio em termos de ação coletiva que a comunidade internacional já enfrentou. Cooperação global na escala necessária só acontecerá se for baseada em acordos globais que considerem as necessidades dos países em desenvolvimento e se criarem os instrumentos financeiros necessários para a transição para uma economia de baixo carbono, assegurando o aporte de recursos financeiros e de tecnologia dos países desenvolvidos nos países em desenvolvimento (ALDY, ORSZAG, STIGLITZ, 2001; STERN, 2007; STERN, 2008; WORLD BANK, 2010).

Para tratar do problema de emissões de GEE é fundamental a criação de um sinal internacional de preço para o carbono de forma a assegurar que as reduções nas emissões aconteçam onde os custos forem menores. Taxação e mecanismos de mercado podem ser 
combinados para se criar um preço para o carbono e qualquer que seja o mecanismo selecionado credibilidade, flexibilidade e previsibilidade são fundamentais para que a política atinja seus objetivos (STERN, 2007). Portanto, tanto a criação de mercados de carbono como impostos sobre o carbono são soluções possíveis para lidar com a externalidade mudanças climáticas.

No caso da solução fiscal, uma possibilidade é a criação de um imposto global sobre emissões. Emissões têm um custo social, e um imposto ambiental comum faria com que todos pagassem pelo custo social de emitir, de acordo com o princípio de que indivíduos e firmas deveriam pagar seus custos marginais totais. Seria necessário que houvesse um entendimento global sobre a valoração dos custos sociais das emissões. O imposto poderia, por exemplo, ser estabelecido de tal forma que o nível global de reduções seja o mesmo que o estabelecido pelo Protocolo de Quioto; a alíquota do imposto poderia ser ajustada para cima ou para baixo. Regimes fiscais terão um papel fundamental em estimular a inovação para a uma economia de baixo carbono (GIDDENS, 2009; STIGLITZ, 2008).

Os pioneiros na criação de impostos sobre o carbono foram os países nórdicos. Na Finlândia foi criado, em 1990, o primeiro imposto sobre $\mathrm{CO}_{2}$ no mundo, com incidência ampla na indústria, transporte e domicílios. Dinamarca, Suécia, Noruega e Islândia seguiram o exemplo, porém com modelos diferentes. O resultado da política fiscal sobre o carbono foi bastante relevante nestes países. Embora o volume absoluto de emissões tenha crescido ao longo da década de 1990 nestes países, estima-se que sem os impostos sobre emissões, tais volumes teriam sido entre 2 a $4 \%$ maiores. A Dinamarca reduziu o volume absoluto de emissões ao longo da década de 1990, a razão sendo que a receita obtida com impostos pelo governo foi utilizada para subsidiar práticas de eficiência energética (GIDDENS, 2009).

Mercados também foram criados para lidar com esta externalidade. Especificamente, o Protocolo de Quioto foi criado com o objetivo de internalizar esta externalidade (SEIFFERT, 2009). Um esforço grande foi feito no sentido de valorar as externalidades negativas geradas pelo problema das emissões de GEE. Neste sentido, montantes necessários para mitigação em países em desenvolvimento foram avaliados em torno de US\$ 140 a US\$ 175 bilhões por ano, ao longo dos próximos 20 anos; e investimentos em adaptação podem custar entre US\$ 30 e US\$ 100 bilhões por ano no período entre 2010 e 2050 (WORLD BANK, 2010). Daí a 
importância dos mercados de carbono para financiar o processo de redução de emissões e a troca de tecnologias.

Embora bem estabelecidos, os mercados de carbono são mercados artificiais, que não existiriam se os governos de diversos países não tivessem estabelecido limites para suas emissões de GEE e não tivessem emitido permissões para emissões (dentro dos limites de emissões estabelecidos) dentro de suas fronteiras (formando o sistema cap-and-trade). Têm por princípio que o carbono é uma commodity e que todos os créditos de carbono são comparáveis e intercambiáveis, permitindo, assim, que emissores vendam no mercado o excesso de permissões, caso tenham reduzido mais do que eram obrigados por lei a reduzir, ou comprem no mercado permissões ao preço de mercado, caso tenham emitido além do permitido por lei.

Mercados de carbono são de dois tipos: o mercado de permissões (allowance markets), em que o governo estabelece um limite para emissões (cap) e permite o comércio destas permissões (trade). Este tipo de mercado responde por $75 \%$ dos mercados de carbono do mundo. O principal mercado deste tipo no mundo é o European Emission Trade System (EU ETS); outros sistemas regionais e nacionais de Emission Trade System operam na Nova Zelândia, Austrália, Suíça, Canadá, Japão, e em uma escala sub-nacional, o Regional Greenhouse Gas Initiative (RGGI), primeiro sistema cap-and trade dos Estados Unidos, um esforço conjunto de dez estados americanos ${ }^{5}$. O segundo tipo de mercado de carbono e o segundo maior, é o mercado de crédito para compensações (offset credits) que permite que entidades sob um sistema cap-and-trade adquiram títulos certificados de reduções de gases de efeito estufa geradas em países que não fazem parte do sistema cap-and-trade. Este mercado foi introduzido pelo Protocolo de Quioto e inclui tanto os projetos de Implementação Conjunta (Joint Implementation - JI) - que prevê a comercialização de créditos de reduções certificadas entre países industrializados e países em transição - e o Mecanismo de Desenvolvimento Limpo (Clean Development Mechanism - CDM) - que prevê a comercialização de créditos de reduções certificadas entre países industrializados e países em desenvolvimento. O CDM é o maior mercado de créditos de carbono baseado em projetos e é

\footnotetext{
${ }^{5}$ Connecticut, Delaware, Maine, Maryland, Massachusetts, New Hampshire, New Jersey, New York, Rhode Island e Vermont.
} 
o principal vínculo entre países desenvolvidos e em desenvolvimento em torno das questões climáticas (LEDERER, 2010).

Há também os mercados voluntários de carbono. Estes podem ser divididos em duas categorias: os voluntários legalmente vinculantes (como o sistema da Chicago Climate Exchange - CCX, que operou de 2003 a 2010), e o voluntário não vinculante, chamado de mercado de balcão. O Mercado da Chicago Climate Exchange era caracterizado por um mercado constituído por adesão de membros voluntários que uma vez que tenham aderido, concordavam com as políticas de redução de emissões da Chicago Climate Exchange e se sujeitavam às penalidades caso não as cumprissem. Fora da CCX há um conjunto enorme de transações voluntárias, que acontecem no mercado de balcão, não orientadas por políticas que limitam as emissões (pelo cap). Assim, a maior parte dos créditos de carbono desta categoria é originária de projetos que reduzem suas emissões e estes créditos são normalmente chamados de Verified ou Voluntary Emission Reductions (VER) (HAMILTON et al, 2008).

$\mathrm{O}$ quadro abaixo mostra as diferenças entre o sistema cap-and-trade (allowances) e o mercado de offsets (créditos de compensação):

Quadro 4: Características dos mercados cap-and-trade e de offsets:

\begin{tabular}{|c|c|c|}
\hline Característica & Cap-and-trade & Offsets \\
\hline Mercadoria trocada & Permissões de emissão & Créditos de carbono; \\
\hline Quantidade disponível & $\begin{array}{l}\text { Determinado pelo limite } \\
\text { global; }\end{array}$ & $\begin{array}{l}\text { Gerado por cada novo } \\
\text { projeto; }\end{array}$ \\
\hline Dinamismo do mercado & $\begin{array}{l}\text { Compradores e vendedores } \\
\text { têm interesses concorrentes } \\
\text { e mutuamente equilibrados } \\
\text { no comércio de } \\
\text { permissões; }\end{array}$ & $\begin{array}{l}\text { Ambos, compradores } \\
\text { vendedores, têm interesse } \\
\text { em maximizar o resultado } \\
\text { gerado por um projeto; }\end{array}$ \\
\hline Fontes & $\begin{array}{l}\text { Normalmente } \\
\text { emissores, tais como o } \\
\text { setor de energia e de } \\
\text { indústrias intensivas no uso } \\
\text { de energia; }\end{array}$ & $\begin{array}{l}\text { Definidas por cada padrão. } \\
\text { Não se limitando apenas } \\
\text { aos setores de elevada } \\
\text { emissão; }\end{array}$ \\
\hline
\end{tabular}




\begin{tabular}{|l|l|l|l|}
\hline Terceiro independente & $\begin{array}{l}\text { Menor papel na verificação } \\
\text { dos inventários de de }\end{array}$ & $\begin{array}{l}\text { Papel fundamental na } \\
\text { verificação da credibilidade } \\
\text { emissões; }\end{array}$ & $\begin{array}{l}\text { linha de base } \\
\text { assegurando, assim, a } \\
\text { autenticidade das reduções } \\
\text { de emissão reivindicadas; }\end{array}$ \\
\hline $\begin{array}{lll}\text { Impacto das emissões no } \\
\text { comércio }\end{array}$ & $\begin{array}{lll}\text { Neutro, dada a natureza da da } \\
\text { soma zero do comércio de } \\
\text { permissões; }\end{array}$ \\
\hline
\end{tabular}

Fonte: SEIFFERT, 2009, p.67

Em 2008 o valor total dos mercados de carbono chegou a US\$ 135 bilhões, o dobro em relação a 2007. Em 2009, apesar da crise financeira, o mercado cresceu para US\$ 143 bilhões (Kossoy, Ambrosi, 2010). Em 2009, o número de projetos registrados no CDM cresceu 50\%; há mais de 1.900 projetos registrados em 58 países e foram emitidas 350 milhões de reduções de emissões certificadas (CERs). Também em 2009 foram comercializadas sob o Protocolo de Quioto um total de 8,7 bilhões de toneladas de carbono, com um valor de mercado de US\$ 144 bilhões (UNFCCC, 2009; UNEP, 2011).

A tabela abaixo resume o volume de carbono e os montantes negociados nos mercados de carbono no mundo, em 2008 e 2009: 
Tabela 1: Volumes de carbono e montantes negociados nos mercados de carbono, em 2008 e 2009:

\begin{tabular}{|c|c|c|c|c|c|}
\hline & & \multicolumn{2}{|c|}{2008} & \multicolumn{2}{|c|}{2009} \\
\hline Mercado & Região / País & $\begin{array}{c}\text { Volume } \\
(\mathrm{MT} \\
\left.\mathrm{CO}_{2} \mathrm{e}\right)\end{array}$ & $\begin{array}{c}\text { Valor } \\
\text { (US\$ } \\
\text { Milhões) }\end{array}$ & $\begin{array}{c}\text { Volume } \\
(\mathrm{MT} \\
\left.\mathrm{CO}_{2} \mathrm{e}\right)\end{array}$ & $\begin{array}{c}\text { Valor } \\
\text { (US\$ } \\
\text { Milhões) }\end{array}$ \\
\hline \multicolumn{6}{|c|}{ Mercados de Permissões (allowance markets) } \\
\hline $\begin{array}{l}\text { European } \\
\text { Trading } \\
\text { System }\end{array}$ & Europa & 3.093 & 100.526 & 6.326 & 118.474 \\
\hline $\begin{array}{l}\text { New South } \\
\text { Wales } \\
\text { Greenhouse } \\
\text { Gas Reduction } \\
\text { Scheme }\end{array}$ & Austrália & 31 & 183 & 34 & 117 \\
\hline $\begin{array}{l}\text { Chicago } \\
\text { Climate } \\
\text { Exchange }\end{array}$ & Estados Unidos & 69 & 309 & 41 & 50 \\
\hline $\begin{array}{l}\text { Regional } \\
\text { Greenhouse } \\
\text { Gas Initiative }\end{array}$ & Estados Unidos & 62 & 198 & 805 & 2.179 \\
\hline $\begin{array}{l}\text { Assigned } \\
\text { Amount Unit }\end{array}$ & $\begin{array}{l}\text { Mercado de } \\
\text { permissões para } \\
\text { países } \\
\text { desenvolvidos } \\
\text { previsto no } \\
\text { Protocolo de } \\
\text { Quioto }\end{array}$ & 23 & 276 & 155 & 2.003 \\
\hline Subtotal & & 3.278 & 101.492 & 7.362 & 122.822 \\
\hline \multicolumn{6}{|c|}{ Mercado spot e mercado secundário de compensações previsto em Quioto } \\
\hline Subtotal & & 1.072 & 26.277 & 1.055 & 17.543 \\
\hline \multicolumn{6}{|c|}{ Transações baseadas em projetos } \\
\hline $\begin{array}{l}\text { Clean } \\
\text { Development }\end{array}$ & $\begin{array}{l}\text { Mercado de } \\
\text { reduções entre }\end{array}$ & 404 & 6.511 & 211 & 2.678 \\
\hline
\end{tabular}




\begin{tabular}{|c|c|c|c|c|c|}
\hline Mechanism & $\begin{array}{l}\text { países } \\
\text { desenvolvidos e } \\
\text { em } \\
\text { desenvolvimento } \\
\text { previsto no } \\
\text { Protocolo de } \\
\text { Quioto }\end{array}$ & & & & \\
\hline $\begin{array}{l}\text { Implementação } \\
\text { Conjunta }\end{array}$ & $\begin{array}{l}\text { Mercado de } \\
\text { reduções entre } \\
\text { países } \\
\text { desenvolvidos e } \\
\text { em transição } \\
\text { previsto no } \\
\text { Protocolo de } \\
\text { Quioto }\end{array}$ & 25 & 367 & 26 & 354 \\
\hline $\begin{array}{l}\text { Mercado } \\
\text { Voluntário }\end{array}$ & & 57 & 419 & 46 & 338 \\
\hline Subtotal & & 486 & 7.297 & 283 & 3.370 \\
\hline Total & & 4.836 & 135.066 & 8.700 & 143.735 \\
\hline
\end{tabular}

Fonte: Autora baseado em KOSSOY, AMBROSI, 2010.

O Clean Development Mechanism e outros mecanismos de mercado para mitigação de emissões baseados em desempenho contribuem para os esforços globais de redução de emissões e para assegurar transferência de recursos de países desenvolvidos para países em desenvolvimento. Especificamente, o CDM teve um crescimento expressivo, estimulou a troca de conhecimento sobre o problema das mudanças climáticas. Porém, não é um mecanismo perfeito: há problemas com a governança fraca, estabelecimento de linhas de base questionáveis, operações ineficientes, escopo limitado, e questões relativas à sua continuidade após 2012. O CDM não reduz as emissões além dos limites acordados no Protocolo de Quioto, mas transfere as reduções das emissões dos países desenvolvidos para os países em desenvolvimento para onde o processo de redução é menos custoso, reduzindo, portanto, os custos de mitigação (WORLD BANK, 2010) . 


\subsection{A sustentabilidade no nível da firma: a formulação da estratégia corporativa}

Apesar da sua origem macroeconômica, as discussões sobre sustentabilidade foram transpostas para o nível das firmas. Replicando as noções de estoques e serviços prestados pelos fluxos dos quatro tipos de capital, a gestão para a sustentabilidade no nível das firmas é avaliada pelos desempenhos nas esferas econômica, ambiental e social (FIGGE, HAHN, 2004; Savitz e Weber, 2006; Elkington, 1998; Hart E Milstein, 2003). A transposição da discussão macroeconômica para o nível das empresas teve grande contribuição de autores de management, como, por exemplo, Elkington (1998), Korten (1995) Hawken, Lovins e Lovins (2000 e 2008).

Para Elkington $(1998 ;$ 2012) a sustentabilidade incorpora o equilíbrio entre prosperidade econômica, qualidade ambiental e justiça social (o chamado triple bottom line) e que estes conceitos serão cada vez mais intensos na agenda estratégica das empresas, sendo um importante driver de competitividade, envolvendo a empresa e sua cadeia de valor:

"Recusar o desafio imposto pelos três pilares é correr o risco de extinção. Esse assunto não diz respeito somente às grandes corporações: estas serão forçadas a repassar a pressão, por meio da cadeia de fornecimento, para seus grandes e pequenos fornecedores e empreiteiros. Essas mudanças vêm de uma profunda reformulação das expectativas da sociedade e, como resultado, dos que servem aos mercados local e global"(ELKINGTON, 2012, p.33).

No mesmo sentido, Korten (1995) aponta que a corporação do futuro é comprometida com o futuro, oferecendo aos seus funcionários empregos seguros e bem remunerados, pagando seus impostos de maneira diligente, gerenciando os recursos naturais de maneira responsável e em mais amplo senso, fazendo a gestão de seus negócios de maneira a considerar os interesses humanos de longo prazo. Neste processo, estão incluídos a sustentabilidade ambiental, a justiça econômica, diversidade cultural e biológica, a noção de que a economia serve os interesses humanos e não vice-versa, a internalização de externalidades e o respeito pela herança comum de recursos naturais e do conhecimento humano acumulado.

Já Hawken, Lovins e Lovins (2000 e 2008) apresentam a ideia de que uma nova revolução industrial está se desenhando onde os interesses dos mundos dos negócios e do ambiente natural estejam profundamente interligados. Também baseado no modelo dos quatro tipos de 
capital, os autores propõem o chamado capitalismo natural (natural capitalism), um paradigma diferente do capitalismo tradicional onde a produtividade dos recursos naturais será muito mais alta, os modelos produtivos serão inspirados na natureza, haverá mudança do modelo de geração de valor nos negócios de venda de produtos para venda de serviços e investimentos substanciais dos negócios no capital natural.

A despeito do fato de o conceito de sustentabilidade carecer ainda de uma definição amplamente aceita e operacional na teoria econômica e na Administração, o termo está presente na missão de inúmeras organizações sejam elas internacionais ou nacionais, cidades, corporações transnacionais, organizações não governamentais. Nestas missões há diferentes compreensões do que é sustentabilidade, mas se observa em todas algumas combinações de desenvolvimento, meio ambiente, equidade, economia e sociedade na tentativa de descrever o que é sustentabilidade. No entanto, cada proponente da sustentabilidade tem uma diferente visão sobre o que deve ser sustentado, desenvolvido, por quanto tempo e qual a ligação com o meio ambiente (PARRIS, KATES, 2003).

Para Barbieri et al (2010) é inequívoca a aceitação por parte das empresas do discurso da sustentabilidade:

\footnotetext{
"a rapidez com que esse movimento foi aceito por amplos setores do empresariado, pelo menos no nível do discurso, não tem precedentes na história recente das empresas". (BARBIERI et al 2010, p. 147)
}

Tanto é assim que o World Business Council for Sustainable Development (WBCSD) divulgou em 2010 sua Visão 2050, que gira em torno da sustentabilidade desempenhando um papel fundamental nas estratégias corporativas. Já na introdução ao documento, assinado pelos CEOs de PricewaterhouseCoopers, Syngenta, Alcoa e Storebrand, há um aviso:

[...] "os negócios tradicionais (business-as-usual) não nos entregarão sustentabilidade ou assegurarão prosperidade econômica e social; estas somente podem ser alcançadas por meio de mudanças radicais, começando agora. Para desempenhar seu papel, as empresas ainda precisam fazer aquilo que fazem melhor: inovar, adaptar, colaborar e executar.[...]". (WBCSD, 2010, p.3) 
Este documento foi preparado com a participação de 29 empresas, representando 14 setores econômicos e expressa uma visão compartilhada para 2050 quando "9 bilhões de pessoas viverão bem e dentro dos limites do planeta" (WBCSD, 2010, p.11). Para que esta Visão seja concretizada, será preciso enfrentar os seguintes desafios (WBCSD, 2010, p.5):

- Resolver os problemas de desenvolvimento humano de bilhões de pessoas, ao mesmo tempo desenvolvendo soluções, estilos de vida e comportamentos mais ecoeficientes ${ }^{6}$;

- A internalização do custo de externalidades, a começar pelo carbono, serviços ecossistêmicos e água;

- Duplicar a produtividade agrícola sem aumentar a taxa de uso da terra e consumo de água;

- Combater o deflorestamento e aumentar a eficiência de florestas plantadas;

- Reduzir pela metade as emissões de carbono, tomando por referência os níveis de 2005, por meio da mudança para sistemas energéticos baseados em baixas emissões de carbono e alta eficiência energética pelo lado da demanda de energia;

- Acesso universal à mobilidade de baixo carbono;

- Uso mais eficiente dos recursos e materiais da ordem de 4 a 10 vezes mais;

Sem dúvida, a visão proposta pelo WBCSD representa uma complexa agenda estratégica para as empresas e é, ao mesmo tempo, um grande desafio e uma grande oportunidade para a competitividade empresarial.

Segundo Savitz e Weber (2006), uma empresa cuja gestão é voltada para a sustentabilidade considera em seu radar estratégico componentes muito além de seus interesses imediatos e tradicionais:

"Uma empresa que busque a sustentabilidade considera interconectados os seus interesses de negócios e os interesses do ambiente natural e da sociedade. Assim, sustentabilidade é a arte de fazer negócios em um mundo interdependente; significa conduzir os negócios de maneira a causar o menor impacto e dano sobre as criaturas vivas e não causar exaustão no ambiente natural, mas antes, restaurar e enriquecê-lo. Sustentabilidade também significa operar um negócio reconhecendo a necessidade e interesses de outras partes tais como, grupos da comunidade, instituições educacionais e religiosas, a força de trabalho, o público - e que este reconhecimento não esgarça, mas ao contrário, reforça a rede de relações que mantêm estas diferentes partes unidas. Para isto, a organização deve (i) identificar um espectro largo de partes interessadas a quem a organização deve prestar contas; (ii) desenvolver um relacionamento transparente com elas; e (iii) encontrar caminhos para trabalhar com estas partes interessadas gerando benefício mútuo. Neste contexto, a

\footnotetext{
${ }^{6}$ Ver Apêndice II para definição de ecoeficiência.
} 
gestão das relações com os stakeholders ganha contornos estratégicos. No longo prazo, criará mais lucro para a companhia e maior prosperidade social, econômica e ambiental para a sociedade." (SAVITZ; WEBER, 2006, p.x -xi).

Assim, uma empresa sustentável contribui para o desenvolvimento sustentável ao gerar, simultaneamente, benefícios econômicos, sociais e ambientais, o triple bottom line (HART, Milstein, 2003; HARRIS et al, 2001; ElKInGTON, 1998). Ainda, para Elkington (2012, p.52), "sustentabilidade é o princípio que assegura que nossas ações de hoje não limitarão a gama de opções econômicas, sociais e ambientais disponíveis para as futuras gerações".

Amparados na definição de Brundtland, Dyllick e Hockerts (2002) definem sustentabilidade corporativa como sendo a satisfação das necessidades dos stakeholders diretos e indiretos de uma firma sem comprometer a habilidade da firma de satisfazer as necessidades de futuros stakeholders. Neste sentido, as firmas precisam manter e crescer sua base de capital econômica, social e ambiental enquanto contribuem, ativamente, para a sustentabilidade no domínio político. Assim, os autores destacam três elementos da sustentabilidade corporativa: (i) a integração de aspectos econômicos, sociais e ambientais em um resultado final tríplice (triple bottom line), considerando que estes aspectos não são estanques, mas profundamente inter-relacionados; (ii) integração entre aspectos de curto e longo prazos; ou seja, a concentração excessiva da atenção dos gestores organizacionais sobre o curto prazo, altamente impactada pelos mercados de ações, é contrária ao espírito da sustentabilidade, que considera como parte da estratégia no presente os interesses dos futuros stakeholders; e (iii) o consumo dos juros e não do principal; o requisito para manter a base de capital é o consumo responsável dos juros, mantendo constantes os principais (o social, o ambiental e o econômico).

As quatro condições sistêmicas (ROBÈRT, 2002) para a construção de uma sociedade sustentável podem também ser traduzidas em impactos e ações sobre as empresas, como ilustra o quadro abaixo: 
Quadro 5: As condições sistêmicas se traduzem em impactos e ações dentro das organizações:

\begin{tabular}{|c|c|c|}
\hline Condições Sistêmicas & $\begin{array}{c}\text { Impactos sobre a } \\
\text { Organização ou Empresa }\end{array}$ & Ações \\
\hline $\begin{array}{l}\text { (I) A natureza não está } \\
\text { sujeita a concentrações } \\
\text { sistematicamente crescentes } \\
\text { de substâncias extraídas da } \\
\text { crosta terrestre }\end{array}$ & $\begin{array}{l}\text { - Eliminar a } \\
\text { contribuição para } \\
\text { aumentos sistemáticos } \\
\text { destas concentrações }\end{array}$ & $\begin{array}{l}\text { - Substituir consumo de minerais } \\
\text { escassos por mais abundantes } \\
\text { - Reduzir dependência de } \\
\text { combustíveis fósseis } \\
\text { - Aumentar eficiência na } \\
\text { mineração }\end{array}$ \\
\hline $\begin{array}{l}\text { (II) A natureza não está } \\
\text { sujeita a concentrações } \\
\text { sistematicamente } \\
\text { crescentes de substâncias } \\
\text { produzidas pela sociedade }\end{array}$ & $\begin{array}{l}\text { - Eliminar a } \\
\text { contribuição para } \\
\text { aumentos } \\
\text { sistemáticos destas } \\
\text { concentrações }\end{array}$ & $\begin{array}{l}\text { - Substituir compostos persistentes e } \\
\text { antinaturais pelos mais abundantes e } \\
\text { que se decompõem mais facilmente na } \\
\text { natureza } \\
\text { - Usar todas as substâncias produzidas } \\
\text { pela sociedade de maneira eficiente }\end{array}$ \\
\hline $\begin{array}{l}\text { (III) A natureza não está } \\
\text { sujeita à degradação } \\
\text { sistematicamente } \\
\text { crescente por meios } \\
\text { físicos }\end{array}$ & $\begin{array}{l}\text { - Eliminar a } \\
\text { contribuição para } \\
\text { degradação física } \\
\text { sistemática da } \\
\text { natureza }\end{array}$ & $\begin{array}{l}\text { - Gerenciar extração de recursos que } \\
\text { venham dos ecossistemas } \\
\text { - Buscar uso mais produtivo e eficiente } \\
\text { dos recursos naturais } \\
\text { - Agir com precaução para qualquer } \\
\text { modificação da natureza }\end{array}$ \\
\hline $\begin{array}{l}\text { (IV) As necessidades } \\
\text { humanas são satisfeitas } \\
\text { em todo o mundo }\end{array}$ & $\begin{array}{l}\text { - Contribuir para a } \\
\text { satisfação das } \\
\text { necessidades } \\
\text { humanas }\end{array}$ & $\begin{array}{l}\text { - Usar os recursos de maneira eficaz, } \\
\text { responsável e com responsabilidade, de } \\
\text { modo que as necessidades de todas as } \\
\text { pessoas cujas vidas influenciamos no } \\
\text { momento e as necessidades futuras dos } \\
\text { que ainda não nasceram tenham as } \\
\text { melhores possibilidade de serem } \\
\text { atendidas }\end{array}$ \\
\hline
\end{tabular}

Fonte: Elaboração própria baseado em Robèrt, 2002

Na essência dos conceitos de gestão estratégica para a sustentabilidade está o conceito de stakeholders.

Desde a publicação inicial em 1949 de 'General and Industrial Management' por Henri Fayol e ao longo destes anos de avanço na ciência da Administração, grande parte das pesquisas em estratégia de empresas privadas foram desenvolvidas tendo por pressupostos a visão de que empresas atendem aos interesses de seus acionistas e têm limitada responsabilidade sobre o efeito que causam sobre outros. Com o surgimento da stakeholder theory em 1984, desenvolvida sob as turbulências econômicas, políticas e sociais que o mundo estava enfrentando no século XX, um novo pressuposto sobre o modelo que deve reger o processo de gestão começa a surgir. Argumentos contundentes começam a surgir questionando o princípio da responsabilidade limitada e do acionista como único "senhor" de uma empresa privada.

Mas não é sem controvérsia que o modelo da teoria dos stakeholders se apresenta à tradicional teoria do acionista (FRIEDMAN, 1970; 1977). Mais do que desafiar os objetivos e metas tradicionais e quantificáveis da firma - na tradicional teoria do acionista estão 
concentrados na função objetivo de maximizar o valor da empresa -, a discussão da teoria dos stakeholders traz em sua essência a visão de que assim como há mais coisas entre o céu e a terra do que sonha a nossa filosofia, há mais para a gestão da empresa que o interesse único do acionista.

Freeman et al (2010) propõem duas definições para o termo stakeholder. Uma mais limitada, onde stakeholders são definidos como sendo aqueles grupos cujo apoio é fundamental para a existência da empresa. Ou posto de outra forma, sem o apoio destes grupos a empresa deixa de existir. E apresentam outra mais ampla, em que stakeholders são quaisquer grupos que podem afetar e serem afetados pela realização dos propósitos de uma organização. Pela visão da teoria do stakeholder, o que cria valor para os negócios são as interações entre estes diversos grupos de stakeholders (tais como clientes, fornecedores, comunidade financeira, comunidades) nas atividades que compõem uma empresa. Entender um negócio é entender como estas relações funcionam e como criam valor; e é papel dos executivos e empresários gerenciar e moldar estas relações (FrEEMAN et al, 2010). Portanto, a questão que é apresentada pela teoria dos stakeholders é a importância que estas relações têm sobre a criação de valor de valor para o negócio. A teoria dos stakeholders forma uma filosofia de gestão e vê a organização como uma entidade em que numerosos e diversos participantes buscam múltiplos propósitos (e muitas vezes não convergentes entre si). É uma teoria que pode ser utilizada para descrever e explicar características e comportamentos corporativos; pode ser utilizada instrumentalmente para identificar as conexões e eventuais lacunas de conexões entre a gestão das partes interessadas e o atingimento dos objetivos corporativos tradicionais. A teoria pode ser utilizada também para interpretar a função da organização, incluindo a identificação de orientações filosóficas e morais para a gestão e operações da organização (DONALSON, Preston, 1995). Gestão de stakeholders tem um papel relevante para a gestão da reputação organização, já que em uma economia em rede, onde dados sobre a empresa estão acessíveis imediatamente para qualquer pessoa, a reputação depende de uma comunicação aberta, comportamento ético e do desenvolvimento de relações com seus stakeholders e em particular com as comunidades em que organização opera (SVENDSEN, 1998). Ainda, os stakeholders têm papel relevante para o sucesso ou fracasso de estratégias corporativas de legitimação social, que são determinadas em processos de negociação política com grupos que tenham o interesse e o poder de impor restrições à empresa (ANSOFF E MCDONNELL, 1993). 
Um dos princípios da sustentabilidade como estratégia empresarial é a gestão de stakeholders; os termos sustentabilidade e stakeholders estão profundamente interligados. Portanto, uma empresa que queira perseguir a sustentabilidade como intento estratégico deve considerar seus stakeholders em seus processos de gestão. Para Elkington (1994;2012), empresas de sucesso não terão outra opção a não ser se envolver com o tema da sustentabilidade e encontrar formas de cooperar com seus fornecedores, clientes, e outros stakeholders (incluindo competidores) em áreas essenciais para os negócios, assegurando vantagens competitivas e responsabilidade social.

Porter e Linde (2000) deram uma contribuição importante na relação entre sustentabilidade e estratégia ao defender a ideia de que demandas ambientais não impactam negativamente a competitividade organizacional, mas antes, levam a inovações que reduzem o custo total do produto pelo uso mais eficiente dos recursos, melhorando a produtividade. O ponto crucial está na forma como as empresas enfrentam as demandas ambientais; na maioria dos casos, ainda são vistas apenas como mal necessário, enfrentadas de maneira reativa e incremental. No entanto, há potencial para grandes benefícios quando (i) se repensa o processo produtivo de maneira inovadora e sistêmica e não pontual; (ii) o impacto ambiental é monitorado e avaliado em todas as fases do processo produtivo, com o auxílio de novas tecnologias, e não apenas ao final. Em suma, a existência de legislação ambiental mais rígida ao contrário de inexoravelmente ser um empecilho à competitividade pode tornar-se um fator que, se examinado de maneira sistêmica e inovadora, traz imensos benefícios ao negócio. Além disso, há evidência de que a gestão responsável para a sustentabilidade pode favorecer comportamento inovador por parte das empresas (BORGER, KRUGLIANSKAS, 2006).

Para Hart e Milstein (2003), há quatro conjuntos de motivadores para as discussões atuais sobre sustentabilidade. O primeiro é a crescente industrialização e seus impactos irreversíveis sobre o ambiente natural. O segundo é o papel cada vez mais relevante que organizações não governamentais e atores da sociedade civil têm ocupado como monitores das atividades empresariais e como criadores de padrões de desempenho sociais e ambientais. $\mathrm{O}$ terceiro é o desenvolvimento tecnológico que pode oferecer soluções para reduzir a pegada humana sobre o planeta. E por fim, o crescimento populacional acentuado (de 1 bilhão de pessoas para 6 bilhões em duas gerações) leva a pressões relevantes por alimentos, melhores condições de vida, distribuição equânime de renda e discussões éticas sobre desenvolvimento humano. Este conjunto de fatores compõe o mosaico das discussões sobre sustentabilidade. Estes 
motivadores, conectados, oferecem oportunidades às empresas de gerarem valor sustentável para seus acionistas. Cada conjunto de motivador da sustentabilidade tem uma estratégia e oportunidades de criação de valor associados. Assim, tendo como motivador a necessidade de redução do impacto sobre o ambiente natural resultante do processo de industrialização, a organização minimiza resíduos e emissões, reduzindo custos e riscos nas operações; ao integrar as perspectivas dos stakeholders nos negócios, a organização obtém legitimação e faz a gestão de sua reputação; a partir do foco no desenvolvimento tecnológico, buscando tecnologias limpas, a organização desenvolve as competências do futuro, apostando em inovação; e, finalmente, ao ter em perspectiva a visão da sustentabilidade global e seus impactos sobre o desenvolvimento humano e às necessidades humanas ainda não satisfeitas, a organização obtém por retorno uma trajetória de crescimento. Portanto, para estes autores a gestão estratégica para sustentabilidade deve ter por orientador a criação de valor para o acionista. A sustentabilidade pode ser fonte de vantagem competitiva e de geração de valor para o acionista e para a sociedade.

Ainda na conexão sustentabilidade e estratégia, estratégias voltadas à sustentabilidade e responsabilidade social só fazem sentido do ponto de vista dos negócios (gerando valor para os negócios) e da sociedade (gerando valor para a sociedade; iniciativas das empresas dispersas e pouco coordenadas não geram impacto social relevante) se estiverem baseadas em uma profunda integração estratégica e operacional entre negócios e sociedade. Ou seja, a gestão para sustentabilidade só criará valor efetivo para as empresas e sociedade se a organização integrar a perspectiva social em suas atividades essenciais, considerando que suas decisões de negócios precisam gerar valor compartilhado entre a empresa e a sociedade. Para tanto, é necessário que os gestores mapeiem e gerenciem, ao logo da cadeia de valor do negócio, os pontos de intersecção entre o negócio e a sociedade. É fundamental que ao analisar estes pontos de intersecção, os gestores analisem e gerenciem os impactos sociais de sua cadeia de valor, buscando geri-los estrategicamente com orçamento, prazos e responsabilidades designados (PORTER E KRAMER, 2006; 2011). É a chamada "estratégia de valor compartilhado", onde a criação de valor compartilhado se daria de três maneiras:

(i) Primeiro, pelo redesenho de produtos e mercados, visando o desenvolvimento de produtos inovadores que atendam às necessidades das sociedades contemporâneas, como, por exemplo, alimentação mais saudável e melhores condições de nutrição, eficiência no consumo de energia, entre outros, assim como pelo atendimento das necessidades de mercados e grupos 
sociais na base da pirâmide (como o proposto por PRAHALAD, 2005). Segundo os autores, o ponto de partida para esta estratégia é a empresa analisar as necessidades sociais, benefícios e danos que estão ou poderiam estar embutidos nos produtos da organização, considerando que as necessidades sociais não são estáticas e mudam com o tempo.

(ii) Em segundo lugar, pela redefinição das bases de produtividade ao longo da cadeia de valor, já que a cadeia de valor afeta e é afetada pelos desafios da sociedade; as externalidades negativas de uma organização refletem também altos custos internos (ineficiências), como, por exemplo, excesso no consumo de energia e de embalagens; portanto, foco em eficiência na produtividade dos funcionários e no uso de recursos naturais e consumo de materiais ao longo da cadeia de valor é chave para a construção da estratégia de "valor compartilhado".

(iii) E, finalmente, pelo desenvolvimento de clusters regionais que apóiem as atividades da empresa nas localidades em que a organização tem operações, incluindo desenvolvimento de infraestrutura de apoio, instituições acadêmicas, associações de comércio etc. Segundo os autores, esta será a nova onda do sistema capitalista, propulsora de inovações e crescimento e embora a proposição de "valor compartilhado" não vá resolver todos os problemas sociais, é a estratégia que pode devolver aos negócios sua legitimação social (PORTER E KRAMER, 2011).

Porter e Kramer (2006) propõem que a gestão estratégica para sustentabilidade seja compreendida e mapeada de dentro da organização para fora (inside-out) e de fora para dentro (outside-in). A figura abaixo ilustra a interdependência entre empresa e sociedade e é o framework proposto pelos autores a ser utilizado pelos gestores para realizar o diagnóstico dos impactos positivos e negativos das atividades ao longo da cadeia de valor (PORTER E KRAMER, 2006): 
Figura 10: Mapeando a interdependência entre negócios e sociedade: impacto social da cadeia de valor (InsideOut)

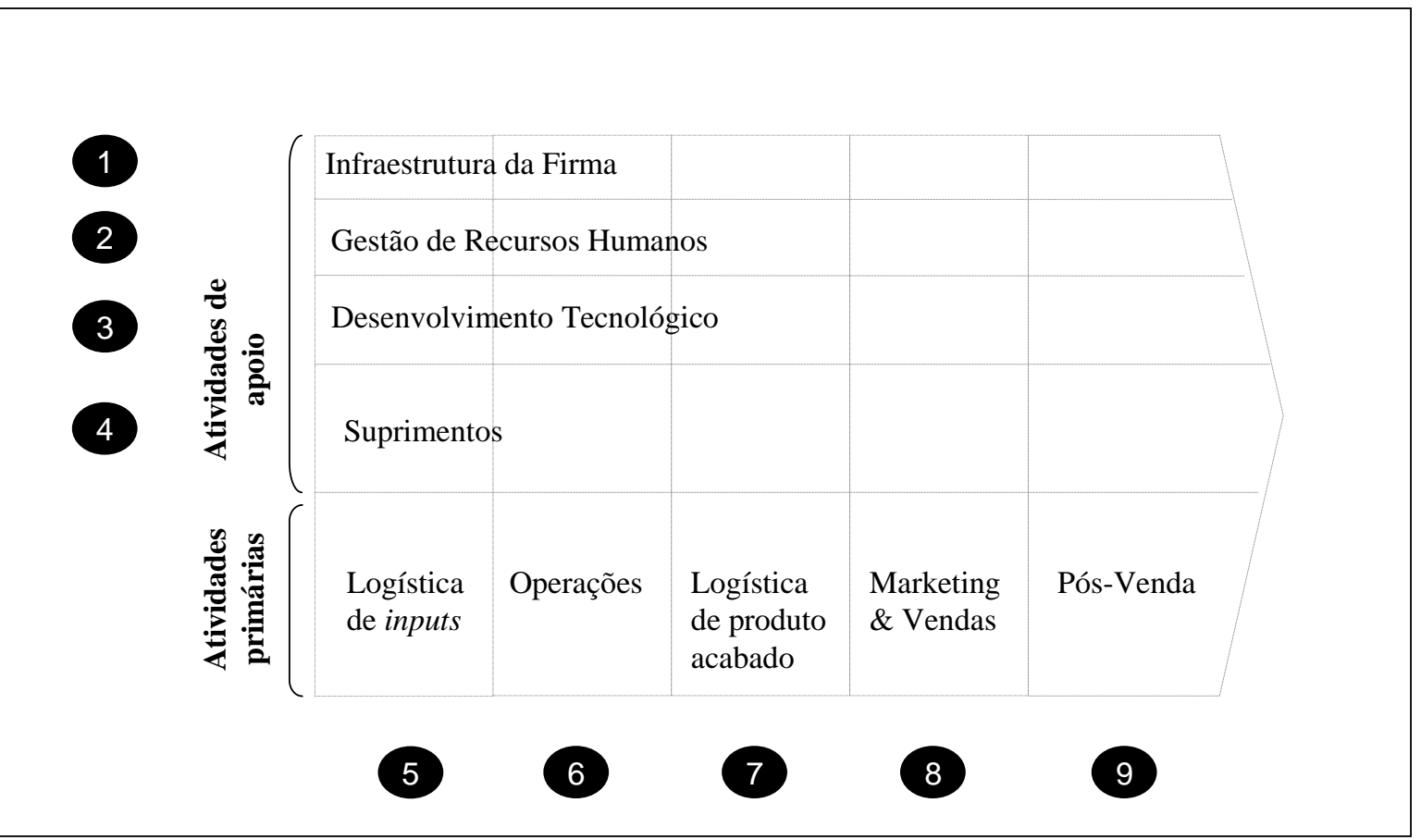

Fonte: PORTER E KRAMER, 2006, p. 8.

Onde:

1). Infraestrutura da firma (ex. finanças, planejamento, relações com investidores). Exemplos de aspectos a serem considerados: práticas de reporte financeiro, práticas de governo, transparência, lobby.

2). Recursos Humanos (ex. recrutamento e seleção, treinamento, sistema de remuneração). Exemplos de aspectos a serem considerados: treinamentos e capacitação dos funcionários, saúde e segurança dos trabalhadores, diversidade e discriminação, benefícios, políticas de remuneração, políticas de demissões.

3). Desenvolvimento Tecnológico (ex: desenho de produto, desenho de processos, pesquisa de materiais, pesquisa de mercado). Exemplos de aspectos a serem considerados: relacionamento com universidades, pesquisas éticas - considerando bem-estar animal, transgênicos, etc -, segurança de produto, conservação de matérias-primas, reciclagem.

4). Suprimentos (ex. componentes, máquinas, publicidade, serviços). Exemplos de aspectos a serem considerados: práticas de gestão de suprimentos e cadeia de valor - tais como, 
corrupção, trabalho infantil, diamantes de zonas de conflito, precificação -, uso de inputs específicos, como pele animal, utilização de recursos naturais.

5). Logística de inputs (ex. estoque de matérias-primas, bases de dados etc). Exemplos de aspectos a serem considerados: impactos do transporte, como, por exemplo, emissões, congestionamentos, etc.

6). Operações (ex. montagem, fabricação de componentes, etc). Exemplos de aspectos a serem considerados: emissões, resíduos, impactos ecológicos e sobre a biodiversidade, uso de água, saúde e segurança dos trabalhadores, relações de trabalho e materiais tóxicos.

7). Logística de produto acabado (ex. processamento de ordem, estoques, preparação de reportes). Exemplos de aspectos a serem considerados: uso de embalagens e disposições finais, impactos do transporte.

8). Marketing e vendas (ex. força de vendas, promoção, propaganda e publicidade, website etc). Exemplos de aspectos a serem considerados: publicidade enganosa, propagandas para crianças, práticas de precificação, informações ao consumidor, privacidade.

9). Serviços de pós-venda (ex. instalações, suporte ao cliente, resolução de conflitos, etc). Exemplos de aspectos a serem considerados: disposição de produtos obsoletos, privacidade do cliente.

A figura abaixo ilustra a visão de fora para dentro (outside-in) e é o framework proposto pelos autores a ser utilizado pelos gestores para o mapeamento das influências sociais sobre o contexto competitivo de uma companhia: 
Figura 11: Mapeando a interdependência entre negócios e sociedade: impacto social sobre a competitividade (Outside-In)

\begin{tabular}{|c|c|c|}
\hline $\begin{array}{l}\text { - Disponibilidade de recursos humano } \\
\text { - Acesso a institutos de pesquisa e } \\
\text { universidades } \\
\text { - Infraestrutura física e administrativa } \\
\text { eficientes } \\
\text { - Disponibilidade de infraestrutura } \\
\text { científica e tecnológica } \\
\text { - Recursos naturais sustentáveis } \\
\text { - Acesso eficiente a capital }\end{array}$ & $\begin{array}{l}\text { Contexto para } \\
\text { estratégia } \\
\text { corporativa e } \\
\text { rivalidade: regras e } \\
\text { incentivos que }\end{array}$ & $\begin{array}{l}\text { - Competição justa (ex: sem barreiras } \\
\text { ao comércio) } \\
\text { - Proteção à propriedade intelectual } \\
\text { - Transparência } \\
\text { - Obediência à lei } \\
\text { - Sistemas de incentivos } \\
\text { meritocráticos }\end{array}$ \\
\hline $\begin{array}{l}\text { Condições dos } \\
\text { fatores (inputs): } \\
\text { presença de inputs } \\
\text { especializados e de } \\
\text { alta qualidade }\end{array}$ & & $\begin{array}{l}\text { Condições para } \\
\text { demanda local: } \\
\text { natureza e } \\
\text { sofisticação das } \\
\text { necessidades dos } \\
\text { consumidores locais }\end{array}$ \\
\hline $\begin{array}{l}\text { - Disponibilidade de fornecedores } \\
\text { locais } \\
\text { - Acesso a firmas em campos } \\
\text { relacionados } \\
\text { - Presença de } \text { clusters }\end{array}$ & $\begin{array}{c}\text { Indústrias } \\
\text { relacionadas e de } \\
\text { apoio: } \\
\text { disponibilidade local } \\
\text { para indústrias de } \\
\text { apoio }\end{array}$ & $\begin{array}{l}\text { - Sofisticação da demanda local } \\
\text { - Demanda por padrões regulatórios } \\
\text { - Necessidades locais específicas que } \\
\text { podem ser aproveitadas em nível } \\
\text { nacional e global }\end{array}$ \\
\hline
\end{tabular}

Fonte: PORTER E KRAMER, 2006, p. 8.

Savitz e Weber (2006) ressaltam que é fundamental que a estratégia corporativa e a estratégia para sustentabilidade tenham grande conexão e para que isso ocorra é necessário que haja intersecção entre lucros e o bem comum. Para os autores, a forma de se chegar à esta zona de intersecção é por meio da minimização dos impactos adversos sociais, econômicos e ambientais da organização e otimizar benefícios e impactos positivos da atuação da organização, nas dimensões social, ambiental e econômica.

Do ponto de vista da firma, a implantação de uma gestão efetiva para a sustentabilidade é um grande desafio. Muitas das questões em torno de aspectos sociais e ambientais do triple bottom line representam, ainda, externalidades. Especialmente para externalidades negativas ligadas a recursos de uso comum, é grande a tentação para free-ride para as organizações uma vez que a inclusão ou priorização destes aspectos na pauta da gestão concorrem com outros mais tangíveis e passíveis de valoração que anos de avanços em pesquisas e práticas de teorias de finanças corporativas já consolidaram. 
Epstein e Roy (2001) e Epstein (2008) apresentam um framework de gestão que busca relacionar como as estratégias corporativas dialogam com os fatores essenciais para o desempenho em sustentabilidade corporativa e afetam o desempenho financeiro da organização. As estratégias corporativas e de unidade de negócios são os primeiros componentes do framework proposto pelos autores porque é pelo desenvolvimento e implantação dessas estratégias que o desempenho em sustentabilidade ocorre. Como parte da formulação e revisão das estratégias corporativas e das unidades de negócios, a organização decide em qual setor deve operar e que recursos e competências serão necessários. Estas estratégias incluem fatores internos e externos que orientam as ações da empresa e que estão relacionadas com aspectos de sustentabilidade, gerando impactos sobre o desempenho financeiro, social e ambiental corporativo. Portanto, as empresas que estão se movendo no sentido da sustentabilidade precisam examinar em que medida os vários elementos relacionados às suas estratégias atuais podem impactar questões ligadas à sustentabilidade. Premissas sobre as relações entre os diferentes elementos listados no framework são determinantes na formulação e implantação da estratégia porque contribuem para que os gestores identifiquem as alavancas que podem ser utilizadas, as ações que podem ser tomadas e o conjunto de sistemas, estruturas, pessoas e cultura necessário para melhorar seu desempenho social e financeiro. 
Figura 12: Framework relacionando a estratégia corporativa, a estratégia para a sustentabilidade e o desempenho financeiro de longo-prazo

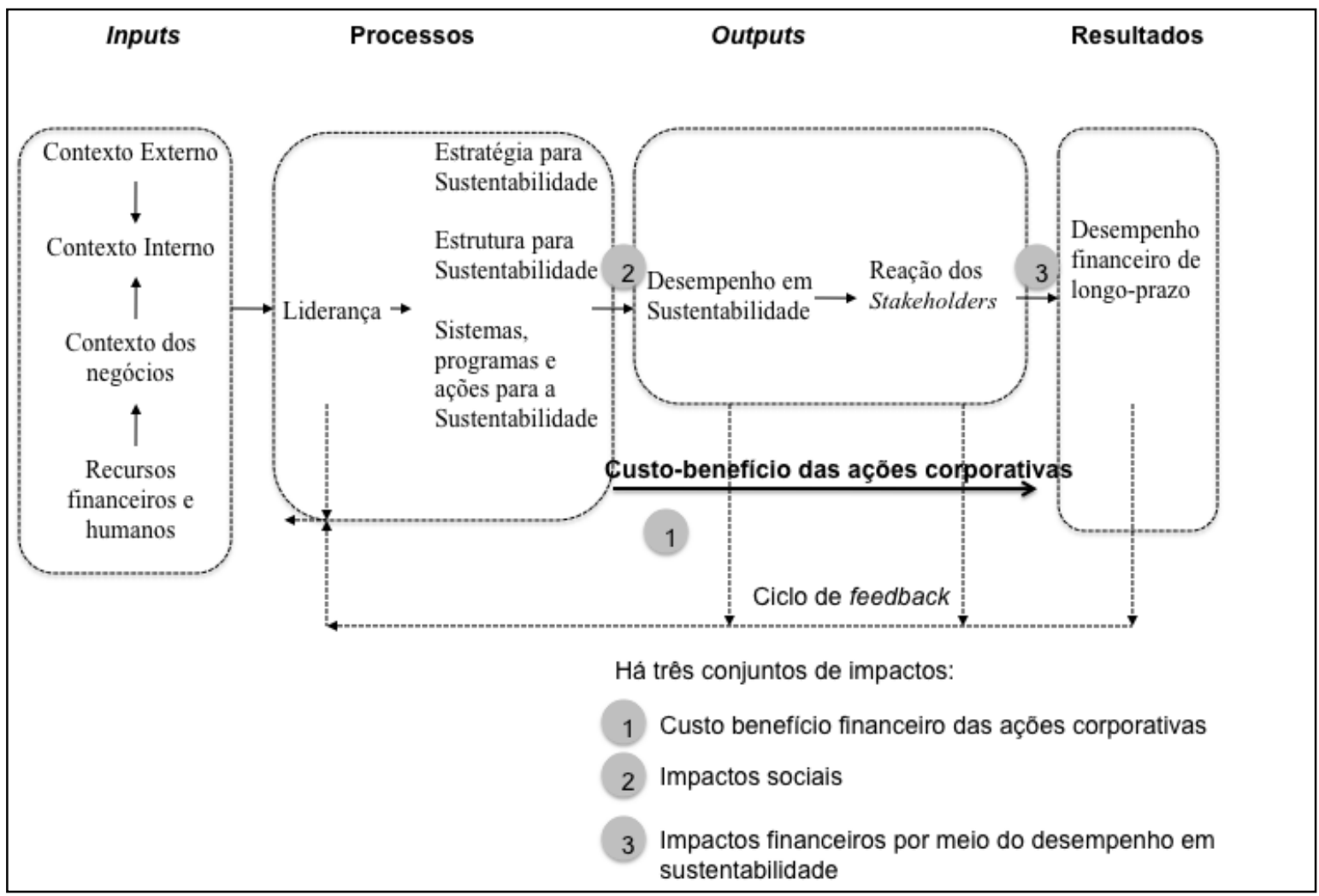

Fonte: Epstein, 2008, p. 46

Ansoff e McDonnell (1993; p.239) apresentam uma série de subprodutos negativos da atuação da empresa privada, exemplos de "insensibilidade às necessidades dos clientes, imperfeições e destruição da concorrência, violação de normas sociais, poluição, interferência política e não atendimento de necessidades sociais prioritárias”. O quadro abaixo apresenta a síntese destes subprodutos:

Quadro 6: Subprodutos negativos das atividades empresariais privadas:

\begin{tabular}{|l|l|}
\hline \multicolumn{1}{|c|}{$\begin{array}{c}\text { Subprodutos negativos das atividades } \\
\text { empresariais }\end{array}$} & \multicolumn{1}{c|}{ Exemplos } \\
\hline $\begin{array}{l}\text { Resposta inadequada a necessidades de } \\
\text { clientes }\end{array}$ & $\begin{array}{l}\text { Política monopolística de fixação de } \\
\text { preços; produtos falsificados; produtos de } \\
\text { má qualidade; }\end{array}$ \\
\hline $\begin{array}{l}\text { Concorrência não funciona como } \\
\text { anunciado }\end{array}$ & $\begin{array}{l}\text { Formação de oligopólios; destruição da } \\
\text { concorrência; crescimento pelo } \\
\text { crescimento; resistência à inovação; }\end{array}$ \\
\hline
\end{tabular}




\begin{tabular}{|l|l|}
\hline $\begin{array}{l}\text { Empresa desrespeita regras de } \\
\text { comportamento social }\end{array}$ & $\begin{array}{l}\text { acordos em causa própria; } \\
\text { política; desonestidade; discriminação; }\end{array}$ \\
\hline $\begin{array}{l}\text { Subprodutos sociais nocivos e } \\
\text { indesejáveis }\end{array}$ & $\begin{array}{l}\text { Condições de trabalho desumanas; } \\
\text { distribuição desigual de riqueza; poluição } \\
\text { ambiental; desequilíbrio ecológico; } \\
\text { esgotamento dos recursos naturais; }\end{array}$ \\
\hline Interferência com a política nacional & $\begin{array}{l}\text { Interesses privados impactando política } \\
\text { externa; conflitos entre empresas } \\
\text { multinacionais e estado nacional; } \\
\text { complexo militar industrial impactando } \\
\text { política de defesa; }\end{array}$ \\
\hline $\begin{array}{l}\text { Empresa não atende necessidades sociais } \\
\text { de elevada prioridade }\end{array}$ & $\begin{array}{l}\text { Habitação de baixo custo; transporte } \\
\text { coletivo; serviços de saúde; decadência de } \\
\text { centros urbanos. }\end{array}$ \\
\hline
\end{tabular}

Fonte: Elaboração própria baseado em Ansoff e McDonnell (1993, p.239)

Como resultado da percepção generalizada da sociedade a respeito dos subprodutos negativos das atividades das empresas, governos e público se unem em medidas visando conter tais subprodutos. Ansoff e McDonnel (1993) citam uma série de exemplos de medidas adotadas pelo governo americano, amparadas pela sociedade, no sentido de restringir tais subprodutos, abrangendo áreas vitais da gestão de uma empresa privada, tais como produção, comportamento na concorrência, lucros excessivos e distribuição de riqueza, uso excessivo de recursos naturais, gestão da propriedade e direitos dos minoritários, gestão de pessoas. Neste sentido, segundo os autores, as reações negativas da sociedade em relação aos impactos negativos das atividades das empresas são de três tipos: (i) relutância em continuar aceitando os subprodutos poluidores do laissez-faire; (ii) recusa em atribuir prioridade exclusiva ao progresso econômico; e (iii) rejeição à ideia do capitalismo como ideologia ou um apelo à modernização do capitalismo para que seja menos poluente (ANSOFF E MCDONNELL, 1993).

Para Steger, Inonescu-Somers e Salzmann (2007), o atendimento a aspectos socioambientais por parte das empresas está muito mais ligado ao cumprimento de legislação, especialmente nos países desenvolvidos, que a busca voluntária pelo triple bottom line. Entretanto, a gestão estratégica para sustentabilidade implica ir além dos requisitos legais, já que nem todas as 
externalidades são internalizadas por meio de políticas públicas. Stakeholders pressionam as organizações para que internalizem cada vez mais as externalidades ambientais que geram. Estas demandas podem se tornar relevantes para os negócios e as empresas precisam encontrar formas de dar atenção a estas demandas ao mesmo tempo em que buscam manter a rentabilidade. Os autores realizaram uma pesquisa - sobre a importância dos riscos socioambientais atribuída pelos gestores organizacionais, a importância atribuída a outros stakeholders que não acionistas, e quanto destas preocupações são de fato internalizadas no dia-a-dia dos negócios - com 114 empresas em 16 países diferentes (Estados Unidos, Canadá, Japão e países europeus), nos setores óleo e gás, utilidades, aviação, automotivo, químico, farmacêutico, tecnologia, serviços financeiros, alimentos e bebidas. Os resultados apontam que a inclusão de aspectos de sustentabilidade nos negócios depende do setor em análise, da influência dos diferentes grupos de stakeholders (sendo no geral as ONGs percebidas como stakeholders mais ativos que consumidores e governo) e das políticas públicas aplicáveis. Também, os resultados apontam que as questões ambientais são percebidas como mais importantes que as questões sociais. Neste sentido, segundo os autores, a resposta das organizações a pressões de stakeholders para que as organizações internalizem externalidades é um contexto mais próximo da realidade das empresas hoje do que a ideia de que empresas perseguirão voluntariamente o triple bottom line, atribuindo pesos equivalentes ao desempenho econômico, social e ambiental.

Para a gestão estratégica corporativa para sustentabilidade - em especial quando se trata da gestão estratégica do risco corporativo - é fundamental que organização conheça, gerencie e monitore os impactos que impõe sobre terceiros, e em particular o uso que faz de recursos de uso comum e de serviços ecossistêmicos, porque é altamente provável que estes impactos sejam objeto de atenção social e política (que podem oferecer um risco à competitividade da firma) ou de novas oportunidades de negócios (que podem oferecer ganhos de competitividade à firma). $\mathrm{O}$ conceito de externalidades deve, portanto, estar no centro da formulação de estratégias para a sustentabilidade de uma organização que considere a sustentabilidade como intento estratégico. 


\subsection{Considerações sobre o referencial teórico}

O referencial teórico buscou apresentar os principais conceitos que fundamentam estratégias para a sustentabilidade. As empresas conhecerem e monitorarem as externalidades negativas ambientais, o impacto que suas atividades econômicas geram direta ou indiretamente sobre bens públicos puros e impuros - e em especial as externalidades negativas associadas a impactos e demandas sobre serviços ecossistêmicos - é fundamental no processo estratégico corporativo de uma organização comprometida com a sustentabilidade. Estes conceitos contribuem para o triple bottom line adicionando objetividade e racionalidade ao processo de seleção e priorização das estratégias corporativas para sustentabilidade. Da ideia do triple bottom line podem surgir questionamentos relacionados a distribuição da importância das três dimensões (sempre econômico, social e ambiental terão igual importância? Para qualquer empresa, em qualquer setor, em qualquer momento no tempo?)

A visão das externalidades negativas como eixo central para o processo de formulação das estratégias corporativas tem por principal pressuposto que estas poderão ser alvo de movimentos para sua internalização, especialmente se seus custos externos forem elevados. Neste sentido, cabe ressaltar que não se trata apenas de uma visão puramente das atividades da firma, mas ao longo de sua cadeia de valor. Impactos adversos ao longo de sua cadeia de valor precisam ser considerados no diagnóstico estratégico. As teorias atuais de formulação estratégica para sustentabilidade abordam em algum grau o conceito de externalidades, mas não de maneira formal e explícita, e pouco oferecem para a argumentação econômica necessária para a construção do chamado business case para a sustentabilidade. Ao monitorar as principais externalidades negativas que a cadeia de valor em que a empresa está inserida gera, o gestor pode fazer a gestão de risco estratégico sociambiental - antecipando eventuais regulações, políticas fiscais, proibições entre outras políticas públicas-, e antever oportunidades de ganhos econômico-financeiros com potenciais novos mercados. Esta ideia contribui para que o gestor da área de sustentabilidade de uma organização possa discutir a importância do tema para a competitividade corporativa nos mesmos termos e sob os mesmos pressupostos que as áreas mais tradicionalmente consideradas essenciais para o bom desempenho dos negócios. 


\section{Capítulo 3: Metodologia de Pesquisa}

\subsection{Método e tipo de pesquisa}

O método de pesquisa utilizado foi o de estudos de casos múltiplos com o objetivo de identificar como as preocupações com a minimização das externalidades negativas ambientais geradas pelas organizações estudadas foram incorporadas nas estratégias corporativas para a sustentabilidade.

Trata-se de uma pesquisa qualitativa, exploratória aplicada, utilizando-se o método de estudos de casos múltiplos. Pesquisas qualitativas envolvem a coleta de dados que está principalmente na forma de palavras, enquanto a pesquisa quantitativa envolve dados que ou estão em formato de números ou podem ser expressos em números (EASTERBY-SMITH, THORPE, JACKSON, 2008).

Quanto aos fins, o estudo trata de uma investigação exploratória aplicada. Exploratória porque foi realizado em área na qual há pouco conhecimento acumulado e sistematizado, não comportando hipóteses. Aplicada, porque tem finalidade prática (VERGARA, 2003).

"Realizam-se estudos exploratórios normalmente quando o objetivo é examinar um tema ou problema de pesquisa pouco estudado, do qual se tem muitas dúvidas ou não foi abordado antes." (SAMPIERI, COLLADO E LUCIO, 2006, p. 99)

Os estudos exploratórios justificam-se para temas ou problemas de pesquisa com base em novas perspectivas ou que não tenham sido abordados antes; oferece aos pesquisadores a oportunidade de compreender o contexto no qual as decisões e ações foram tomadas. A pesquisa qualitativa e os estudos exploratórios são aplicados para entender, de maneira aprofundada, as motivações, razões e contextos onde surgem e são desenvolvidas as crenças que levam a ações. Cabe ressaltar que para o caso de pesquisas no campo social, lida-se com questões ligadas a ações humanas. O que diferencia os seres humanos do mundo natural é a habilidade de falar. E a fala - seja pela conversa ou leitura - é um importante e útil instrumento para auxiliar no entendimento sobre o que as pessoas pensam e por que agem como agem (MYERS, 2009). 
Quanto aos meios, esta pesquisa é de campo e estudo de caso; de campo porque é uma investigação empírica realizada nos locais onde ocorrem os fenômenos a serem explicados; estudo de caso por ter caráter de profundidade e detalhamento e por ser circunscrita às empresas estudadas. Segundo Yin, o estudo de caso busca esclarecer como decisões foram tomadas, seus motivos, como foram implementadas e quais os resultados obtidos (VERGARA, 2003).

Yin define o método do estudo de caso como sendo "uma investigação empírica que investiga um fenômeno contemporâneo dentro de seu contexto de vida real, especialmente quando os limites entre o fenômeno e o contexto não são claramente definidos" (YIN, 2005, p.32). Para Yin (2005), a investigação de estudo de caso enfrenta uma situação tecnicamente única que apresenta mais variáveis de interesse do que pontos de dados, baseia-se em várias fontes de evidências, com dados precisando convergir em um formato de triângulo e beneficia-se do desenvolvimento prévio de proposições teóricas para conduzir a coleta e análise de dados.

Estudos de casos múltiplos são aqueles que contêm mais de um caso único, assemelhando-se a experimentos múltiplos, ou seja, seguindo a lógica da replicação em oposição à lógica da amostragem. As evidências resultantes de casos múltiplos são consideradas mais convincentes, e o estudo global é visto como algo mais robusto (HERRIOT, FIRESTONE, 1983 apud YIN, 2005, p.68).

O método de replicação dos estudos de casos múltiplos está ilustrado na figura abaixo: 
Figura 13: Método de replicação dos estudos de casos múltiplos

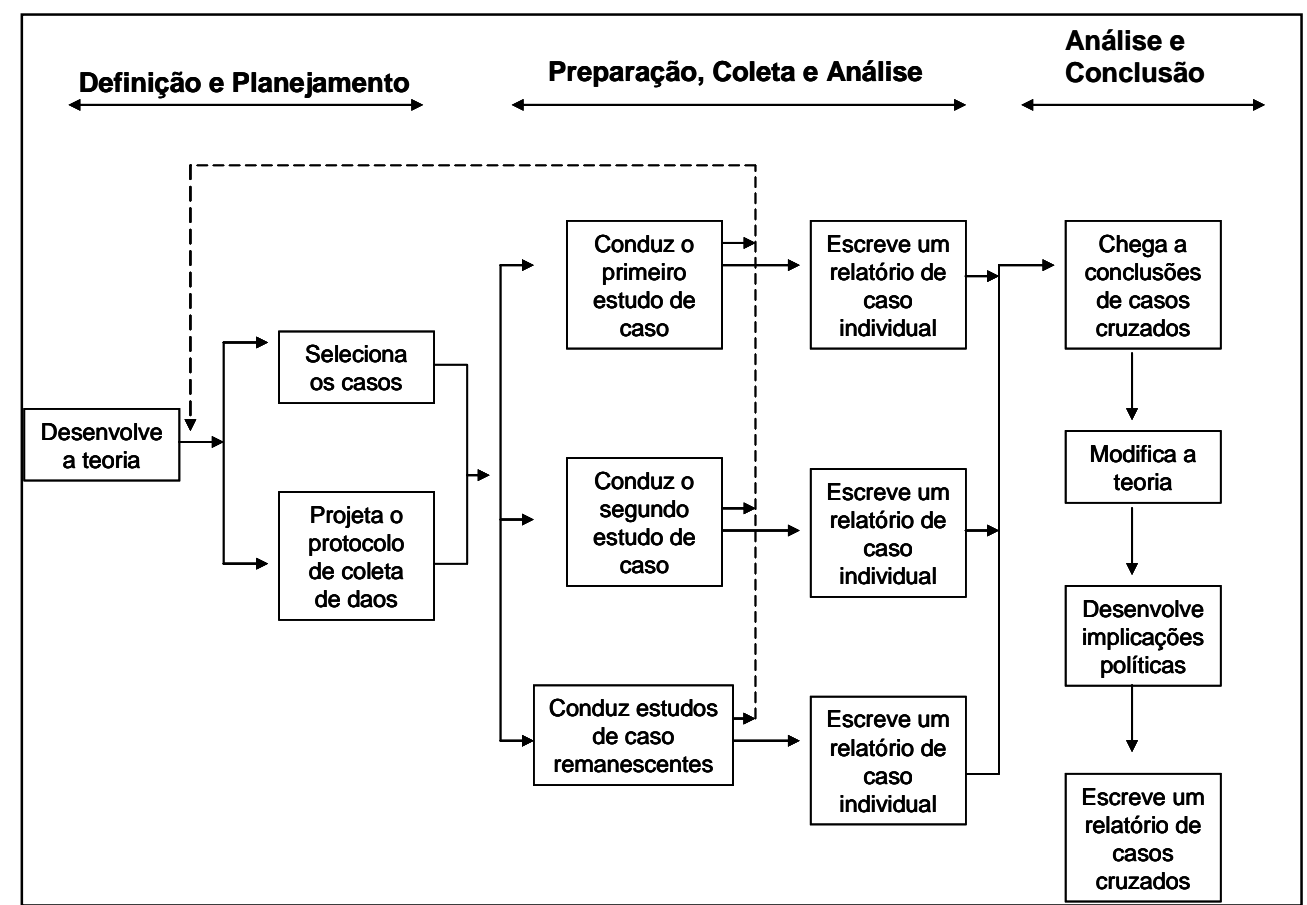

Fonte: YIN, 2005, p.72

O esquema acima indica que o desenvolvimento da teoria é a etapa inicial. A seleção dos casos é de suma importância para o processo de planejamento e coleta dos dados. Cada caso é um estudo completo, obtendo-se conclusões; as conclusões de cada caso são informações a serem replicadas por outros casos. (YIN, 2005, p.72).

As descobertas que podem ter ocorrido durante a realização de um estudo de caso individual estão representadas pela linha pontilhada. Neste caso, o projeto deve ser reavaliado e se necessário, fazer-se ajustes no protocolo ou mesmo selecionar novos casos sob pena de o pesquisador ser acusado de distorcer ou ignorar a descoberta. Ainda, é fundamental para estudos de casos que o pesquisador utilize várias fontes de evidência, realizando um processo de triangulação. Assim, qualquer descoberta ou conclusão em um estudo de caso provavelmente será mais acertada se baseada em várias fontes distintas de informação (YIN, 2005).

Estudos de casos contribuem para avanços teóricos na medida em que as tentativas de reconciliar evidências entre os casos estudados, diferentes tipos de dados, diferentes pesquisadores e entre os casos e a literatura aumentam a possibilidade de contribuir de 
maneira criativa para mudanças no quadro teórico. As constantes justaposições entre realidades conflitantes tendem a descongelar a forma de pensar do pesquisador e, portanto, o processo todo tem um potencial de gerar teoria com menos viés do pesquisador do que quando comparado com a teoria construída a partir de estudos incrementais. Adicionalmente, a teoria gerada a partir de estudos de casos tende a ser empiricamente válida, já que o processo de construção da teoria está fortemente amparado em evidências empíricas. Cabe ressaltar que quando se sabe pouco sobre o fenômeno estudado, ou quando as perspectivas teóricas atuais não parecem adequadas para explicar o fenômeno, porque têm pouca comprovação empírica, ou porque há conflitos entre as perspectivas teóricas existentes ou com o senso comum, então se justifica usar o método de estudos de casos. O resultado esperado da aplicação deste método é desenvolver, ou ao menos iniciar o desenvolvimento, de teoria (EISENHARDT, 1989).

\subsection{Modelo conceitual}

O modelo conceitual de pesquisa explora as conexões entre a revisão bibliográfica e o problema de pesquisa. É também o modelo mental que o pesquisador leva ao campo para orientar o processo de entrevista e posteriormente, de análises.

O modelo conceitual foi desenhando considerando os seguintes aspectos:

- Análise e diagnóstico dos impactos e demandas sobre os bens públicos, públicos impuros, em especial, os recursos de uso comum e privados da cadeia de valor em que a organização está inserida; a análise dos impactos e demandas sobre os serviços ecossistêmicos é a proxy para esta etapa. Esta análise será tão bem-feita quanto maior for o envolvimento de stakeholders-chave. O processo de engajamento de stakeholders relevantes é fundamental para que a organização consiga mapear os impactos e demandas sobre os serviços ecossistêmicos de maneira mais abrangente possível, assim como possíveis mudanças no ambiente institucional que impactarão a forma como eventuais externalidades negativas serão (ou não) internalizadas. Ora, a capacidade da organização de analisar tais aspectos é limitada; daí a importância de envolver os stakeholders;

- A partir da análise dos impactos e demandas sobre os serviços ecossistêmicos e os riscos e oportunidades ligados às diversas formas possíveis e cabíveis de internalização de 
externalidades (que estão diretamente relacionadas ao ambiente institucional), pode-se construir a argumentação de negócios (o chamado "business case") ligados aos aspectos ambientais que compõem a estratégia sustentabilidade. A análise destes riscos e oportunidades - que pode ser tão sofisticada quanto a organização desejar - , prepara a organização para estabelecer prioridades nos aspectos ambientais que compõem a estratégia de sustentabilidade como também para selecionar e priorizar grupos de stakeholders a serem engajados nas estratégias ambientais;

- O próximo passo é o diálogo destes aspectos com a estratégia corporativa, para que haja alinhamento estratégico e engajamento interno da organização;

- A partir de então, a organização implementa suas estratégias desenhadas, resultado de um processo ordenado e racional (as deliberadas) e/ou como resposta às situações e contextos que encontra no ambiente externo (emergentes);

- A avaliação do desempenho organizacional de curto, médio e longo prazos é fundamental para o processo estratégico. Nesta fase é importante também o envolvimento de stakeholders relevantes, já que há diversas dimensões envolvidas no desempenho organizacional. Esta fase retro-alimenta as etapas anteriores. Para não escapar ao escopo deste tese, este aspecto do processo estratégico não foi explorado. A figura abaixo ilustra o modelo conceitual de pesquisa: 
Figura 14: Modelo conceitual da pesquisa:

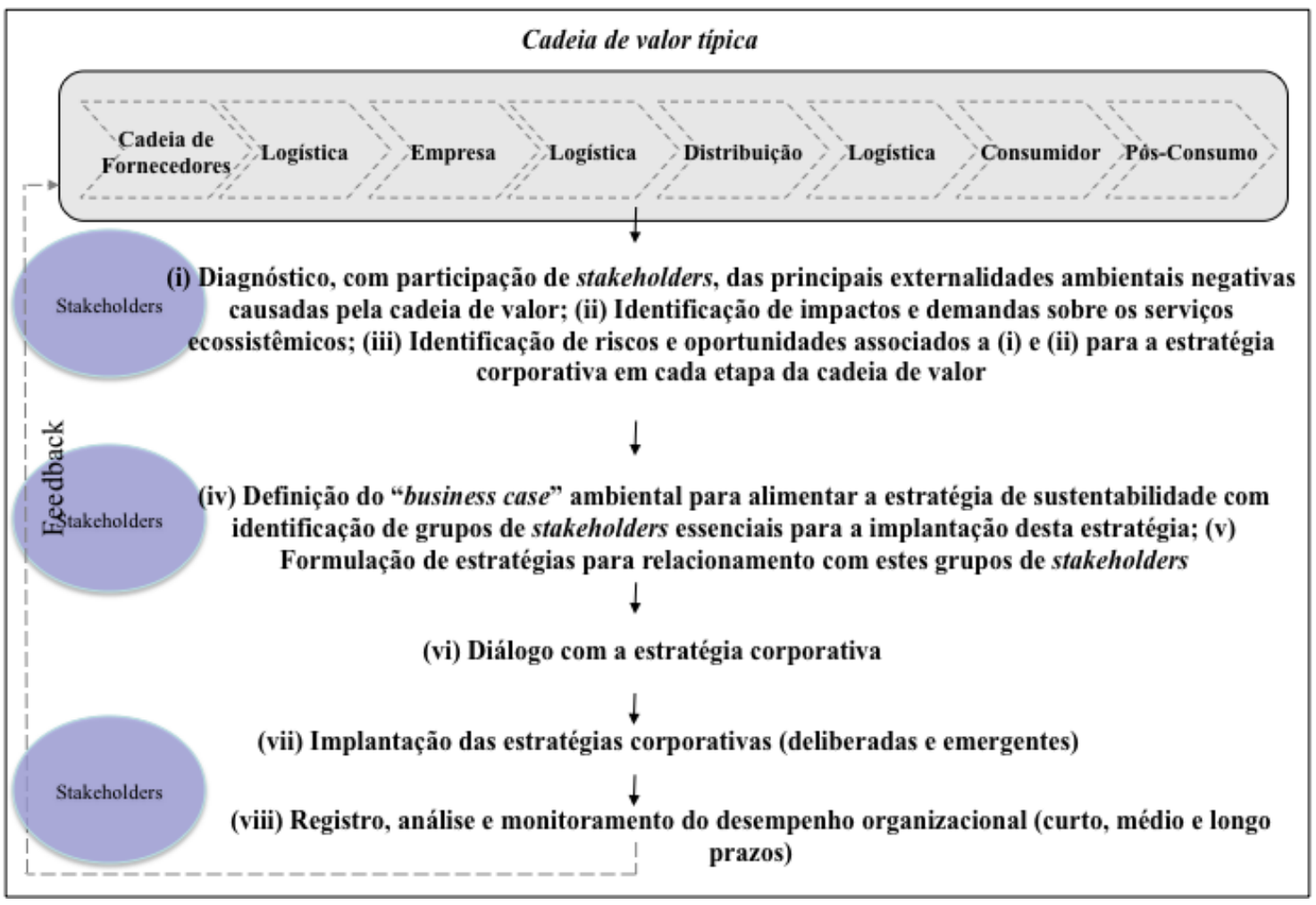

Fonte: Elaboração própria

A figura abaixo esquematiza o modelo conceitual para o diagnóstico de externalidades ambientais negativas, impactos e demandas sobre os serviços ecossistêmicos, riscos e oportunidades para a estratégia corporativa em cada etapa da cadeia de valor: 
Figura 15: Modelo conceitual para o diagnóstico de impactos e demandas sobre os serviços ecossistêmicos , riscos e oportunidades para a estratégia corporativa:

Serviços ecossistêmicos

\section{Provisão Regulação Culturais Suporte}

\section{Stakeholders}

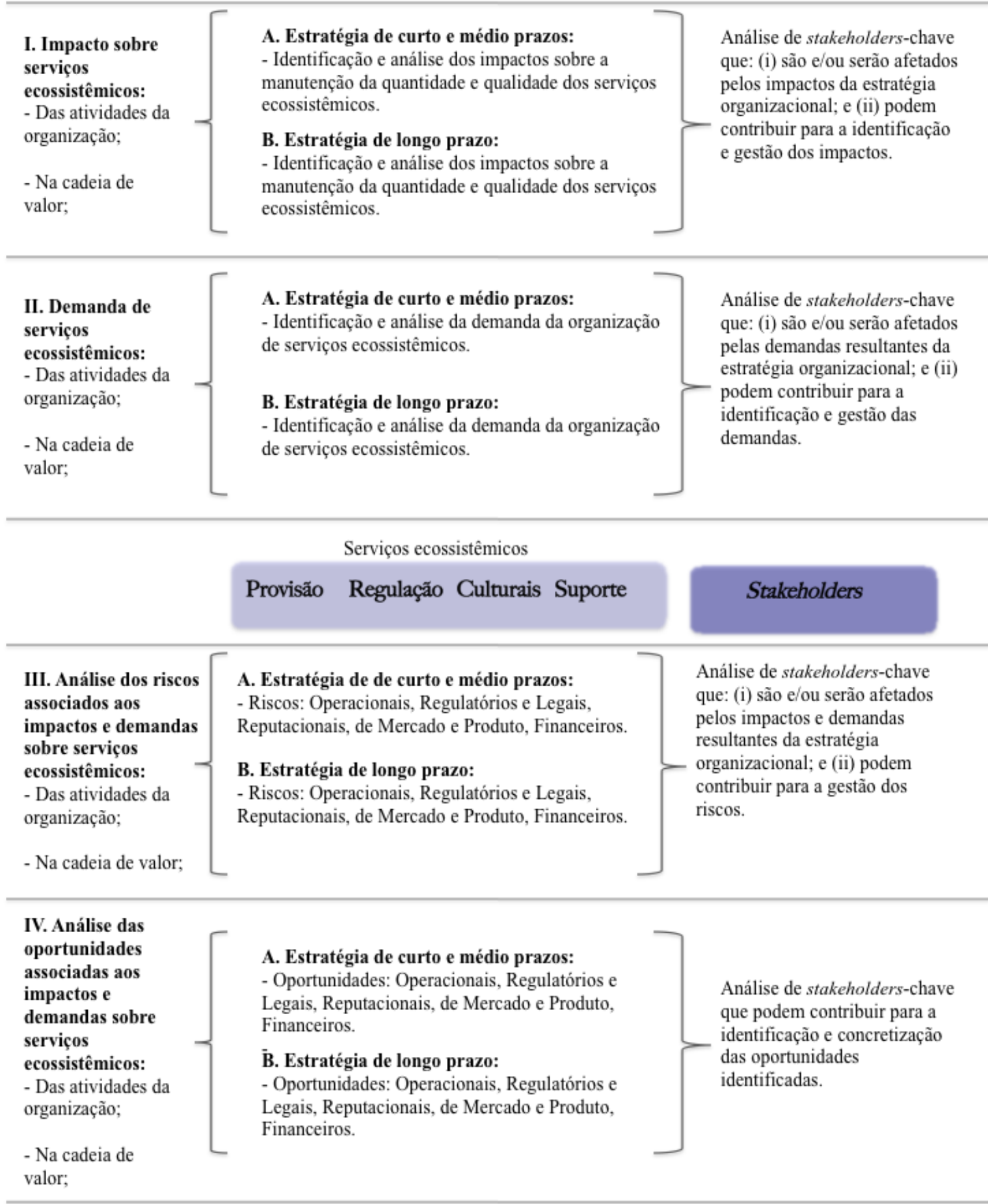

Fonte: Elaboração própria com base em Hanson et al, 2012 e MEA, 2005 
Cabe destacar alguns aspectos quanto ao escopo desta pesquisa:

- O objeto deste estudo é a organização. As teorias apresentadas representam a base teórica sobre a qual são analisadas as estratégias organizacionais para a sustentabilidade, a partir, principalmente, da relação entre a organização e seu contexto externo, particularmente o econômico e ambiental;

- As práticas e procedimentos utilizados pelas organizações em busca de melhores resultados no âmbito ambiental são apenas relatados. Não são objetos de discussão os possíveis papéis da organização na sociedade; portanto, não são discutidos conceitos e práticas de Responsabilidade Social Empresarial (RSE), Responsabilidade Social Corporativa (RSC) ${ }^{7}$ ou abordagens correlatas (HOURNEAUX JR.,2010, p.18).

\subsection{Seleção dos casos}

Unidade de análise é a entidade que forma a base de qualquer amostra (EASTERBY-SMITH, THORPE, JACKSON, 2008). Para atingir os objetivos desta pesquisa e para responder o problema de pesquisa, o estudo teve como unidade de análise o processo de formulação de estratégias corporativas para a sustentabilidade nas empresas selecionadas para a pesquisa que atenderam aos seguintes critérios: (i) possuam operações no Brasil; e (ii) tenham formalmente declarado a sustentabilidade como intento estratégico, expresso em documentos formais como Relatórios Anuais, websites, declarações públicas de seus principais executivos (entrevistas a jornais, revistas etc). Procurou-se selecionar organizações de setores econômicos distintos.

Os casos foram selecionados de forma não probabilista e intencional, por conveniência. Não probabilista em razão da não aleatoriedade; intencional porque segundo Marconi e Lakatos (2002, p. 52) neste tipo de pesquisa o pesquisador tem interesse particular na "opinião de determinados elementos da população, mas não representativos dela". A escolha das empresas foi, portanto, intencional.

\footnotetext{
7 Adota-se aqui o conceito de Responsabilidade Social Empresarial (RSE) e Responsabilidade Social Corporativa (RSC) proposto por Carroll (1979 apud CARROLL e BUCHHOLTZ, 2008): RSE e RSC englobam as expectativas econômicas, legais, éticas e filantrópicas da sociedade com relação às atividades organizacionais, em um determinado momento.
} 


\subsection{Instrumentos de Pesquisa}

Dados primários foram obtidos pessoalmente pela autora deste estudo junto aos profissionais das empresas pesquisadas identificados como responsáveis pela formulação de estratégias socioambientais. Foram realizadas entrevistas seguindo roteiros semi-estruturados. Entrevistas semi-estruturadas e não estruturadas são métodos apropriados quando: (i) é necessário entender os construtos que os respondentes usam como base para formar suas opiniões e crenças sobre uma situação ou tema particular; (ii) o objetivo da entrevista é desenvolver um entendimento do "mundo" do respondente de forma que o pesquisador possa influenciá-lo, tanto de maneira independente como dependente; e (iii) a lógica de uma situação não é clara; quando o tema é altamente confidencial; e quando há questões em que o respondente reluta em mencionar, a não ser em uma entrevista individual cujo conteúdo é considerado confidencial. O objetivo das entrevistas é revelar os significados e interpretações que as pessoas atribuem aos eventos estudados (EASTERBY-SMITH, THORPE, JACKSON, 2008).

Dados secundários foram obtidos por meio de livros, artigos, dissertações e teses, bem como material institucional, demonstrações financeiras e balanços sociais das instituições pesquisadas.

Segundo Yin (2005), o protocolo para o estudo de caso é mais do que um instrumento; contém o instrumento, os procedimentos e as regras gerais que deverão ser seguidas ao se utilizar o instrumento. $\mathrm{O}$ protocolo serve de guia para o pesquisador ao realizar a coleta de dados e aumenta a confiabilidade da pesquisa.

No Apêndice I está apresentado o Protocolo para os Estudos de Casos. 


\subsection{Limitações do Método}

O método do estudo de caso apresenta limitações. Algumas constatações e conclusões do estudo podem refletir alguma tendência anterior do pesquisador. Entretanto, o rigor dos procedimentos de pesquisa, como por exemplo, fidelidade ao protocolo de estudo e roteiro de entrevista, podem contribuir para a minimização desta limitação. Outro aspecto importante é a impossibilidade de se generalizar os resultados obtidos. Yin (2005, p.29) argumenta que

"estudos de caso, da mesma forma que experimentos, são generalizáveis a proposições teóricas, e não a populações ou universos. Nesse sentido, o estudo de caso, como o experimento, não representa uma 'amostragem', e ao fazer isso, seu objetivo é expandir e generalizar teorias (generalização analítica) e não enumerar frequiências (generalização estatística)."

O método de estudo de casos permite apenas conclusões específicas para os casos estudados, não permitindo conclusões genéricas nem mesmo para o setor das empresas estudadas (CAMPOMAR, 1991). Assim, não se pretende concluir sobre o universo da pesquisa, mas conhecer as práticas de ligadas às formulações estratégicas de sustentabilidade das empresas pesquisadas. 


\section{Capítulo 4: Análise dos Resultados}

São três as empresas selecionadas que compõem os estudos de casos. As três empresas ou são listadas na bolsa de valores de São Paulo ou pertencem a grupos empresariais que são. Este fato tem implicações legais e, por esta razão, e considerando a natureza sensível dos conteúdos tratados nesta pesquisa, foram adotados pseudônimos para os nomes das empresas, sem prejuízo das análises. Na verdade, nestes casos a confidencialidade favorece as análises, na medida em que os entrevistados sentem-se mais livres para responder às indagações da pesquisadora. Os pseudônimos adotados são homenagens a grandes nomes da poesia brasileira: Mario Quintana (MQ), Cecília Meireles (CM), e Carlos Drummond de Andrade $(C D A)$.

A primeira empresa, "Mario Quintana" (MQ), é uma holding de grande conglomerado brasileiro do setor da construção civil. Na holding são formuladas as estratégias de sustentabilidade para o todo o grupo. A segunda empresa, "Cecília Meireles" (CM), é uma grande empresa brasileira do setor petroquímico. A terceira, "Carlos Drummond de Andrade" (CDA), representa um grande conglomerado financeiro nacional.

As empresas pesquisadas possuem projetos de responsabilidade social, investimento social privado e marketing de causa. Em razão do escopo desta tese, estes aspectos não serão apresentados, nem discutidos. $\mathrm{O}$ foco está concentrado em questões ambientais relacionadas às estratégias para sustentabilidade. 
4.1 Estudo de caso: a empresa "Mario Quintana”

\section{Das Utopias}

Se as coisas são inatingíveis... ora! Não é motivo para não querê-las... Que tristes os caminhos se não fora A mágica presença das estrelas!

(Mario Quintana)

Para a realização deste caso foram realizados encontros e entrevistas com o Gerente e a Diretor $^{8}$ da área de Sustentabilidade da empresa, distribuídos ao longo de um ano. Em alguns destes encontros, representantes da área de Planejamento Estratégico estavam presentes. $\mathrm{O}$ Diretor da área Sustentabilidade tem formação em Ciências Políticas e pós-graduação lato sensu na área de Recursos Humanos. Está na empresa há mais de cinco anos. O gerente tem formação em Engenharia, pós-graduação lato sensu em Gestão e está na empresa há cinco anos. Ambos tiveram experiências profissionais anteriores em responsabilidade social e em negócios.

\subsubsection{Contexto da empresa}

O Grupo empresarial ao qual pertence a holding "Mario Quintana” foi fundado ao final da década de 1930. Desde então, a área de atuação do Grupo foi sendo expandida e diversificada. De controle familiar, o Grupo atua hoje no negócio de engenharia e construção, cimentos, energia, transporte, calçados, indústria naval, incorporação imobiliária e siderurgia. As empresas do Grupo estão organizadas operacionalmente por áreas de negócio que estão distribuídas em:

(i) Negócios que respondem pela maior parte da receita do Grupo, compostos pelas unidades de cimento, concessões de energia, concessões rodoviárias e construção;

(ii) Negócios nos quais o Grupo tem participação acionária, compostos pelas unidades de calçados, meio ambiente e

Box 1: Compromissos externos voluntários

- "MQ" não é signatária de acordos voluntários, mas as empresas que compõem o Grupo são. Entre os compromissos das empresas que compõem o Grupo, estão: Pacto Global, Empresas pelo Clima, Cement Sustainability Initiative, Caring for Climate, Pacto Empresarial pela Integridade contra a Corrupção, Programa Empresa Amiga da Criança, Programa Na Mão Certa, Objetivos do Milênio;

- Duas empresas do Grupo estão na composição do Índice de Sustentabilidade Empresarial para o ano de 2012.

Fontes: Relatórios Anuais, 2010 e websites das empresas.

\footnotetext{
${ }^{8}$ Cargos e gênero alterados e detalhes omitidos para assegurar confidencialidade.
} 
siderurgia; e (iii) Negócios em desenvolvimento alinhados com a estratégia de longo prazo do país, compostos pelas unidades de incorporação imobiliária, naval e operações aeroportuárias.

Adicionalmente, o Grupo possui negócios e investimentos ligados à agropecuária, aviação e manufatura têxtil. É um grupo com atuação internacional, notadamente nos negócios de cimento e construção civil. Entre os negócios do Grupo no exterior, há plantas de cimento em diversos países distribuídos na Europa, China, Índia, África do Sul, Argentina, Angola entre outros; os negócios de construção estão presentes no Peru, Moçambique, Argentina, Venezuela, Colômbia e Angola. Os negócios aeroportuários do Grupo também são internacionais, com atuação na América Latina e Caribe.

Ao todo, o Grupo possui cerca de 60.000 funcionários e em 2010, obteve receita líquida de cerca de $\mathrm{R} \$ 20$ bilhões e lucro líquido de cerca $\mathrm{R} \$ 2$ bilhões. A tabela abaixo apresenta algumas informações financeiras do Grupo:

Tabela 2: Informações financeiras selecionadas do Grupo ao qual pertence a holding "Mario Quintana":

\begin{tabular}{|l|l|l|}
\hline Em R\$ bilhões & $\mathbf{2 0 1 0}$ & $\mathbf{2 0 0 9}$ \\
\hline Receita líquida & Cerca de 17,0 & Cerca de 16,0 \\
\hline Lucro Líquido & Cerca de 1,0 & Cerca de 2,0 \\
\hline EBITDA & Cerca de 3,0 & Cerca de 3,0 \\
\hline Investimentos & Cerca de 5,0 & Cerca de 4,5 \\
\hline Ativos Totais & Cerca de 35,0 & Cerca de 30,0 \\
\hline Patrimônio Líquido & Cerca de 9,5 & Cerca de 9,5 \\
\hline
\end{tabular}

Fonte: Relatório Anual, 2010

A holding "Mario Quintana" tem por objetivo exercer a gestão corporativa das empresas do Grupo, abrangendo aspectos estratégicos e operacionais. Também, é responsável por coordenar os recursos humanos, técnicos e financeiros das empresas controladas e contribuir para a formulação das estratégias das empresas do Grupo. Portanto, a empresa "MQ" desempenha um papel importante de influência sobre a definição das estratégias do Grupo, mas não é, em última análise, a responsável pela execução e implantação das estratégias dos diferentes negócios do Grupo. Cada empresa do Grupo tem autonomia para desenvolver suas próprias estratégias (e o faz sob influência e coordenação das diretrizes corporativas). 


\subsubsection{Missão e valores}

O Grupo, cujo representante público para a sociedade é a holding "MQ", se apresenta como uma empresa cidadã, cujos pilares estratégicos estão fundamentados no lucro econômico, respeito ao meio ambiente e equidade social. Também, a missão do Grupo (embora não explicitamente chamada de "missão") é expressa como sendo a de construir o Brasil do futuro.

Os valores do Grupo são: (i) respeito às pessoas e ao meio ambiente: agir de forma correta em relação a acionistas, profissionais, clientes, fornecedores, governos, comunidades locais e sociedade em geral. Atuar com responsabilidade em relação ao meio ambiente; (ii) atuação responsável: atender ao que é estabelecido na legislação, agindo de forma íntegra. Respeitar a diversidade de acordo com as normas universais de boa convivência humana, sem discriminação de raça, credo, religião, cargo, função ou outra; (iii) transparência: fornecer informações claras e abrangentes sobre as atividades, as realizações, as políticas e o desempenho do Grupo, de maneira sistemática e acessível; (iv) foco no resultado: buscar sempre maximizar o desempenho do Grupo, como forma de garantir sua perenidade, seus investimentos, o retorno aos acionistas e às condições adequadas aos profissionais; (v) qualidade e inovação: garantir a qualidade de serviços e produtos e investir continuamente no aperfeiçoamento dos profissionais e das empresas.

\subsubsection{Estratégia para a sustentabilidade}

Embora a entrada do tema sustentabilidade na pauta estratégica dos negócios do Grupo tenha ocorrido formalmente em 2006, o início deste processo deu-se bem antes, mais especificamente no ano 2000 com a fundação do Instituto que representa as ações de investimento social privado do Grupo. Criado para viabilizar os investimentos sociais do Grupo, no período de 2000 a 2006 o Instituto dedicou-se a projetos sociais na área de educação, saúde e cultura para crianças e adolescentes de famílias de baixa renda. Em 2006, o Instituto redefiniu seu papel dentro do Grupo, passando a buscar maior alinhamento entre suas políticas de investimento social privado e os negócios do Grupo. Em 2006 é também quando o tema sustentabilidade passa a integrar de maneira formal a agenda estratégica do Grupo empresarial, por meio de diretrizes estabelecidas pela holding "Mario Quintana". 
Atualmente, o Instituto trabalha em parceria com as empresas do Grupo e tem por foco de atuação a primeira infância, educação e geração de renda, prioritariamente nas cidades onde as unidades de negócio do Grupo estão localizadas.

Ao mesmo tempo que o movimento complexo entre empresas do Grupo, Instituto e demandas da sociedade levou à redefinição da atuação do Instituto, também mudou a relação do Grupo com o tema sustentabilidade. A inserção formal da sustentabilidade no processo estratégico do Grupo tem suas origens em 2006, quando os acionistas, preocupados com questões que poderiam afetar a perenidade dos negócios (e influenciados pela experiência e conhecimentos trazidos do Instituto), desafiaram os executivos das diversas empresas que compõem o Grupo a inovarem na condução dos negócios. Todo ano, o Conselho envia aos executivos do Grupo um documento onde são dadas orientações quanto às suas expectativas para o negócio para o ano seguinte e para os próximos cinco anos. Em 2006, foi a primeira vez que o tema sustentabilidade compôs este documento e desde então, é papel da área de sustentabilidade da "MQ" prover as orientações para o Conselho quanto aos aspectos de sustentabilidade que devem estar presentes neste documento.

Desde 2006 o tema da sustentabilidade vem entrando paulatinamente na agenda estratégica do Grupo, especialmente em razão da atuação da Diretoria de Sustentabilidade da "MQ". Com estrutura enxuta, característica de uma holding, a Diretoria de Sustentabilidade conta com uma equipe de quatro pessoas (Diretor, Gerente, Assistente e Secretária). O Diretor compartilha seu tempo também com o Instituto (70\% Sustentabilidade, 30\% Instituto).

Para a "MQ", a sustentabilidade está altamente relacionada com a inovação e seu posicionamento corporativo com relação à sustentabilidade, realizado em 2006, foi e continua sendo baseado em 6 principais aspectos:

- Inovar de maneira contínua;

- Atender às demandas ligadas ao desenvolvimento humano, em harmonia com a vida na Terra;

- Evoluir na oferta de produtos e serviços, melhor servindo os clientes atuais e futuros;

- Desenvolver produtos e serviços cada vez mais ecoeficientes;

- Fortalecer e desenvolver as comunidades próximas de suas plantas e atividades produtivas. 
A preocupação com sustentabilidade teve seu início com ecoeficiência, ou seja, a preocupação em consumir insumos e energia de forma mais eficiente. As metas que foram lançadas aos executivos das diversas empresas do Grupo foram incluídas como metas operacionais e que afetam a remuneração variável dos diversos executivos do Grupo. As empresas que compõem o Grupo receberam prêmios ligados à sustentabilidade.

Além dos aspectos mencionados, a estratégia de sustentabilidade da "MQ" tem dois importantes sub-temas, que orientam as estratégias das empresas que compõem o Grupo: Gestão do Carbono e Amazônia.

\section{- Plano de Gestão do Carbono}

Em 2009, em função tanto dos avanços nas discussões a respeito das mudanças climáticas em particular, com a publicação da Política Nacional sobre Mudanças do Clima (Lei 12.187/2009) - como da relevância do nível de emissões de gases de efeito estufa dos negócios que compõem o Grupo (em especial aqueles ligados a cimento e construção civil), a "MQ", representando todo o Grupo, incluiu a gestão do carbono como um dos principais pilares da agenda de sustentabilidade do Grupo. Lançou um compromisso público com a gestão do carbono, construído coletivamente com a participação de 150 executivos do Grupo, onde, de maneira geral, as empresas do Grupo se comprometem a (i) incluir a preocupação com as emissões de gases de efeito estufa nas análises que compõem o planejamento estratégico, as decisões de negócios e de investimentos; (ii) realizar inventários periódicos de emissões de gases de efeito estufa e perseguir metas de redução tanto absolutas como específicas (por tonelada de produto); (iii) investir em reutilização e armazenamento de carbono, assim como em atividades de reflorestamento; (iv) formar parcerias com a sociedade civil, governo e instituições de pesquisa no sentido de gerar inovações ligadas à mitigação e adaptação às mudanças climáticas e se engajar em campanhas de conscientização da sociedade no que tange a estes temas; (v) incluir a busca por produtos de menor pegada de carbono em seus processos de compra de insumos; (vi) contribuir para a formulação de políticas públicas ligadas às mudanças climáticas. Também, o plano de gestão do carbono inclui um programa de treinamento dos gestores ligados aos negócios de cimento e construção civil. Em 2011, 200 funcionários (de todas as empresas do Grupo) participaram de workshops sobre a questão climática. Adicionalmente, 60 funcionários envolvidos diretamente com 
inventários e gestão de emissões participaram de treinamentos específicos sobre o tema e sobre os mercados de carbono.

O plano de gestão do carbono tem como meta a redução de $21 \%$ das emissões de gases de efeito estufa do negócio de construção civil até 2016 e de 37\% até 2010. Estas metas estão contempladas na metas operacionais dos executivos destes negócios e têm impacto sobre a remuneração variável.

A gestão do carbono como posicionamento estratégico do Grupo veio como resposta aos riscos e oportunidades que o tema de mudanças climáticas oferece ao Grupo (conforme mencionado pelos entrevistados), em especial porque $80 \%$ das emissões de gases de efeito estufa do Grupo estão concentradas nos negócios de construção e cimento.

Como parte do plano de gestão do carbono, desde 2009 são realizados inventários de gases de efeito estufa no negócio de construção civil - 44 obras executadas pela empresa construtora do Grupo passaram por diagnóstico quanto às emissões de Gases de Efeito Estufa (como o Grupo considerou no inventário as emissões relacionadas à fabricação e ao transporte dos materiais utilizados nas obras, as emissões relacionadas a fabricação de cimento foram também consideradas).

Quanto à adoção plena do "Plano de Gestão do Carbono", cabe destacar um diálogo ocorrido durante a entrevista que é bastante ilustrativo do processo que leva da decisão para a ação:

“- Pesquisadora: Como a "MQ" pode assegurar que as estratégias desenhadas, como o "Plano de Gestão do Carbono" estejam sendo adotadas, em igual grau de compromisso, pelas empresas que compõem o Grupo?

- Diretor de Sustentabilidade: Bem, o processo de formulação destas estratégias é participativo, com os principais executivos das áreas de negócios participando das decisões, via o fórum dos "Amigos da Sustentabilidade" . Mas claro que há negócios que adotam mais e outros menos. Por exemplo, há uma empresa do Grupo que está me "enrolando" para iniciar o processo de inventário de gases de efeito estufa, apesar de estar aprovado em orçamento.

- Pesquisadora: E em sua opinião por que isso está acontecendo?

- Diretor de Sustentabilidade: Porque eles não consideram este tema material para o negócio deles, e realmente não o é. É material para os negócios de

\footnotetext{
${ }^{9}$ Nome trocado para assegurar a confidencialidade do caso.
} 
cimento e construção, que respondem por $80 \%$ das emissões de gases de efeito estufa do Grupo. Já para esta empresa que estou comentando, o que é realmente material é o consumo de água. Então, eles têm trabalhado muito no

desenvolvimento de soluções para a redução de consumo de água, inclusive trabalhando com a cadeia de valor para disseminar soluções. Outro aspecto material é o uso de amaciantes químicos. Eles têm buscado soluções para trocar o uso de químicos nos amaciantes e uma das soluções desenvolvidas foi um amaciante que tem por matéria-prima o cupuaçu. Isso também resultou em geração de renda para 70 famílias da região em que a empresa opera.”

A empresa citada pelo Diretor tem iniciativas que visam reduzir suas emissões de gases de efeito estufa, ainda que esteja resistindo à realização do inventário. Mas, de acordo com essa conversa, o gatilho para levar a empresa da decisão para a ação, é o termo "materialidade".

\section{- Amazônia}

Ao longo de 2011, a "MQ” formulou uma estratégia específica para a Amazônia - estratégia esta que foi submetida ao Conselho e aprovada em final de Dezembro de 2011. A previsão de comunicação desta estratégia é para 2012.

A razão pela qual o Grupo considerou a Amazônia suficientemente importante para que fosse desenhada uma estratégia socioambiental para ela reside no seguinte aspecto:

"Nos próximos 20 anos, $80 \%$ da receita da empresa de construção do Grupo virá de obras na região. Não é mais uma discussão de se vamos para a Amazônia, mas de como vamos." (Diretor de Sustentabilidade da "MQ")

O Grupo está, então, se antecipando a um movimento estratégico do negócio, trazendo a estratégia socioambiental para apoiar a estratégia geral da companhia. A estratégia da Amazônia guarda grande conexão com o Plano de Gestão do Carbono, porque um dos aspectos do Plano é a atuação do Grupo no sentido de contribuir para evitar o deflorestamento, especialmente no contexto da construtora já que grandes obras frequentemente envolvem derrubada de florestas. A estratégia para Amazônia é resultado do trabalho desenvolvido pelo fórum de "Amigos da Sustentabilidade" (detalhado mais à frente neste documento). 
Assim, as macros linhas de atuação de "MQ" em gestão para sustentabilidade são: (i) apoio ao Conselho de Administração na definição de estratégias de sustentabilidade para o Grupo; (ii) apoio às empresas do Grupo na formulação e implantação de suas estratégias de sustentabilidade; (iii) interlocução com stakeholders externos quanto aos temas afeitos à sustentabilidade no âmbito da holding; (iv) fomento à formação de competências em temas afeitos à sustentabilidade.

4.1.4. O processo de formulação das estratégias para a sustentabilidade e o diálogo com a formulação das demais estratégias

O processo de formulação de estratégias de sustentabilidade para o Grupo é formado por duas etapas distintas que se relacionam.

\section{- A primeira: o Fórum dos "Amigos da Sustentabilidade”}

Em 2006, foi reunido um conjunto (atualmente 17) de Diretores das áreas de negócios das empresas que compõem o Grupo, chamados de "Amigos da Sustentabilidade". Este grupo de diretores se reúne cinco vezes ao ano para discutir a agenda estratégica de sustentabilidade para todo o Grupo. Este é um processo liderado pela área de sustentabilidade, em conjunto com a área de planejamento estratégico, ambas da "MQ".

Nestas reuniões, são discutidos os temas socioambientais materiais para os negócios do Grupo e estratégias para lidar com eles. A área de sustentabilidade tem o papel de provocar as discussões, trazendo o conteúdo mais técnico; já a área de planejamento estratégico, faz a ponte com as estratégias gerais da companhia. Neste sentido e para contribuir para a qualidade das discussões nestas reuniões, as duas áreas têm trabalhado em conjunto para construir uma ferramenta que considere aspectos socioambientais nas decisões de negócios e investimentos e que contribua para que o processo de tomada de decisão no âmbito do fórum dos "Amigos da Sustentabilidade" seja considerado legítimo e alinhado às demandas dos diferentes negócios do Grupo.

A ferramenta, ainda em construção, prevê a consulta a stakeholders internos e externos para levantamento dos aspectos socioambientais materiais que podem impactar o projeto de investimento em análise. Neste processo, holding ("MQ") e unidades de negócios trabalham 
de forma bastante alinhada, no sentido de buscar as melhores informações que possam contribuir para a identificação de impactos socioambientais materiais. No âmbito externo, as equipes levarão em conta os inputs providos por ONGs locais e Governos (em suas diferentes instâncias) para compor o diagnóstico de impactos sociais e ambientais; e Instituições de

Ensino para o de impactos sociais. As equipes da Unidade de Negócio (empresa do Grupo que esteja desenvolvendo o projeto) das áreas de Supply, Jurídica, de Recursos Humanos e de Sustentabilidade serão as responsáveis por avaliar impactos socioambientais, econômicos, de inovação e governança. E do vínculo com a holding ("MQ") via Instituto e a área de sustentabilidade da "MQ" vêm também inputs socioambientais, econômicos, de inovação e governança. Cada projeto será avaliado pelo desempenho em cinco dimensões: Inovação, Econômica, Governança, Social e Ambiental. Os projetos serão classificados, de acordo com o desempenho, em quatro categorias: (i) nível impeditivo (luz vermelha): projetos assim classificados estão abaixo dos requisitos mínimos de legislação e regulamentações local e setorial. Projetos nesta categoria representam necessariamente e de imediato, riscos e contingências para a empresa; (ii) nível mínimo (luz amarela): nível exigido pelo Grupo para operar qualquer planta/empresa em qualquer lugar do mundo, independente de leis e regulamentações. É o menor patamar de sustentabilidade aceitável pelo Grupo; (iii) exigência do Grupo (luz verde): nível desejável pelo Grupo a ser atingido pelas Unidades de Negócio nos próximos anos. Projetos de greenfield ou aquisições que estiverem classificadas neste nível devem considerar em suas projeções econômico-financeiras de longo prazo os investimentos necessários para alcançar as aspirações de sustentabilidade do Grupo. As aspirações podem estar relacionadas a riscos e contingências futuras, no caso de mudança de legislação e regulamentação; (iv) aspiração (estrela): nível mais alto de práticas de sustentabilidade. Atingir este nível significa ser referência em sustentabilidade, que o projeto em análise opera da forma mais sustentável possível dentro da realidade na qual está inserido.

Estes são os elementos que compõem a estrutura do modelo de tomada de decisão para o qual o grupo está caminhando, em um alinhamento bastante fino entre a área de sustentabilidade e a de planejamento estratégico. 
Figura 16: Estrutura da ferramenta de avaliação de impactos socioambientais nos processos de investimento em desenvolvimento pela "MQ"

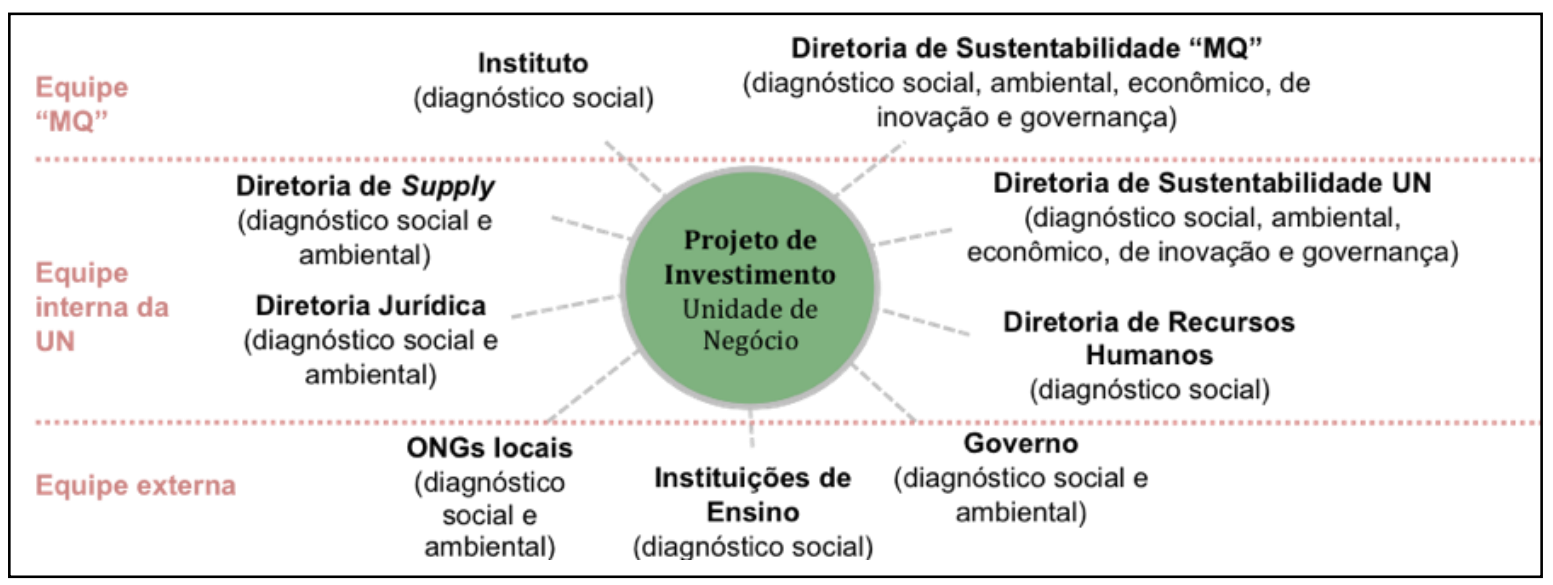

Fonte: Equipe de planejamento estratégico "MQ"

- A segunda: o nível de sustentabilidade ${ }^{10}$

"Em 2008, a nossa Presidente sentiu a necessidade de traduzir as questões de sustentabilidade em uma linguagem mais próxima dos negócios, de forma mais gráfica." (Diretor da área de sustentabilidade)

Foi então que a equipe de sustentabilidade da "MQ" desenvolveu uma ferramenta chamada de "nível da sustentabilidade". Trata-se de uma ferramenta gráfica que aponta o desempenho de cada empresa do Grupo nas cinco dimensões anteriormente citadas (Inovação, Econômica, Governança, Social e Ambiental). Para avaliar o desempenho nestas cinco dimensões, foi desenvolvido um questionário socioambiental com 40 questões formuladas pela área de sustentabilidade da "MQ", complementadas por análises dos questionários do Dow Jones Sustainability Índex - da Bolsa de Nova Iorque-, do Índice de Sustentabilidade Empresarial da Bolsa de Valores de São Paulo - , e do Guia Exame da Boa Cidadania Corporativa. O questionário contempla o ano vigente, o seguinte e os cinco próximos. A partir da análise dos resultados do gráfico, as empresas do Grupo fazem seu planejamento quanto a aspectos socioambientais. Um exemplo de análise do "nível de sustentabilidade" impactando o processo de planejamento, foi da área de suprimentos de uma das empresas pertencentes ao Grupo que, ao analisar seu desempenho no gráfico, considerou que seria importante desenvolver um projeto para uma "cadeia de suprimentos sustentável”. Esta empresa, com o apoio da área de sustentabilidade da "MQ", se juntou a mais 3 outras empresas do Grupo e estão desenvolvendo este projeto para se beneficiar das sinergias operacionais.

\footnotetext{
${ }^{10}$ Nome trocado para assegurar a confidencialidade.
} 


\subsubsection{Reflexões e interpretações dos dados levantados}

Com base nos dados levantados, depreende-se que à medida que as discussões globais sobre sustentabilidade foram avançando e, consequentemente, as pressões externas às organizações foram se intensificando, as práticas de "MQ" com relação a temas socioambientais também foram sendo adaptadas a este cenário competitivo de crescente instabilidade e complexidade. Como resultado, em 2006, uma orientação expressa do Conselho de Administração mudou, definitivamente, o rumo da gestão estratégica para a sustentabilidade deste Grupo empresarial de grande importância para a economia brasileira. Depreende-se das entrevistas que antes de 2006, aspectos socioambientais eram considerados menos estratégicos, mais operacionais. E que a partir de 2006, são alçados à condição de estratégicos, com fronteiras estendidas para além dos muros das empresas quem compõem o Grupo, ou seja, para além da noção de ecoeficiência (segundo os depoimentos). Das entrevistas fica claro também que de 2006 até o momento, vem mudando o processo de se pensar estratégias socioambientais para o Grupo.

Foi expresso pelos entrevistados que as questões socioambientais não podem ser apenas operacionais - menos ainda filantrópicas -; elas precisam ser "materiais", estarem "diretamente alinhadas as negócios", como expressaram, mais de uma vez o Gerente e o Diretor de sustentabilidade ao longo das entrevistas. Entretanto, ser "material" e "estar alinhado aos negócios" são conceitos que pareceram um tanto vagos e difíceis de serem claramente detalhados pelos entrevistados ao longo das entrevistas; pareceram intuitivos, ainda em processo de racionalização. Este fato não surpreende, em especial considerando a complexidade dos temas sociais e ambientais contemporâneos, ainda mais para um Grupo com atuação em um escopo geográfico tão amplo como o "MQ".

A partir do conteúdo das entrevistas é possível sintetizar e organizar o atual processo de formulação de estratégias de sustentabilidade na "MQ"e o diálogo com as demais estratégias corporativas como demonstra a figura abaixo: 
Figura 17: Fluxo simplificado do processo de formulação de estratégias de sustentabilidade na "MQ":

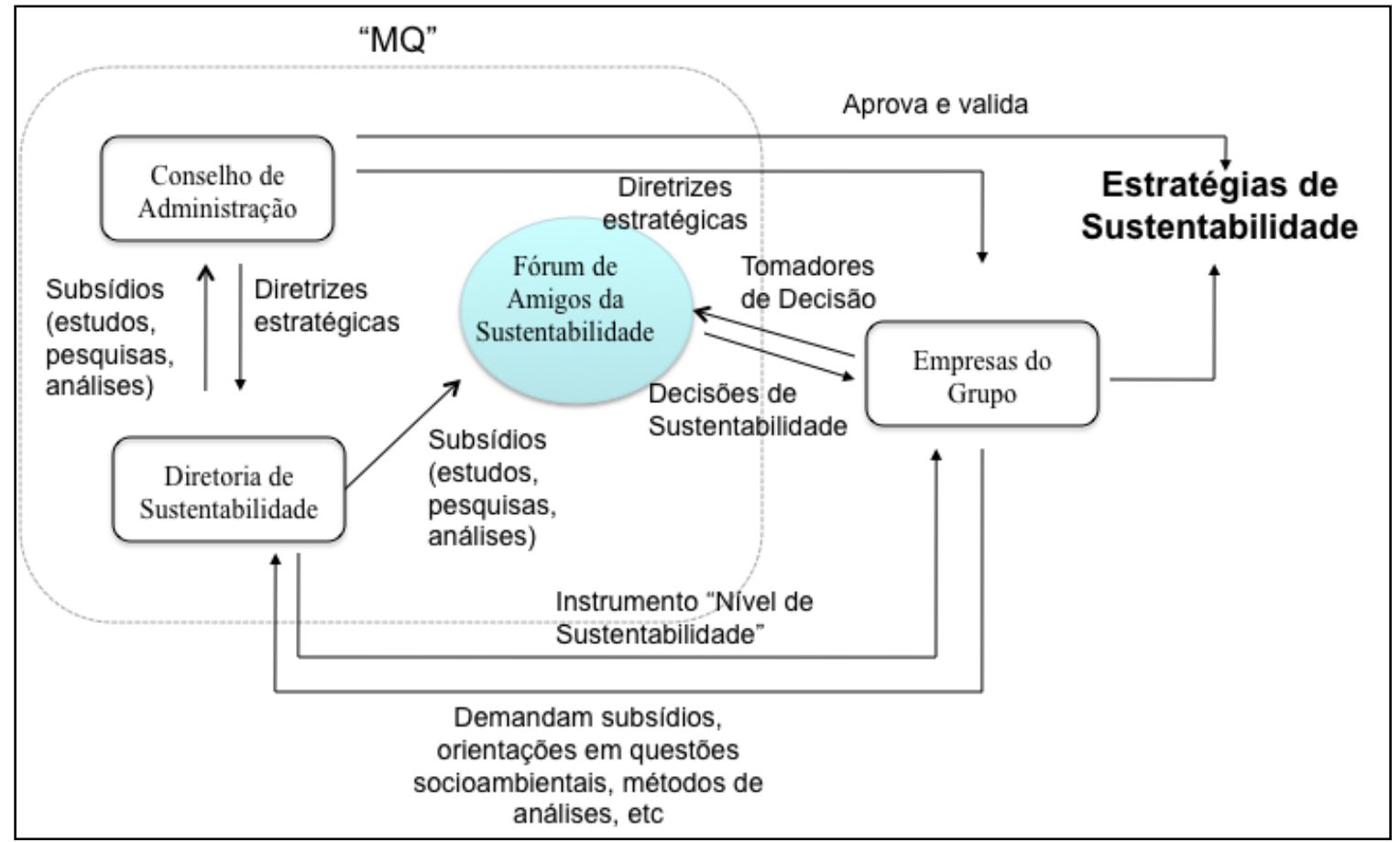

Fonte: elaboração própria a partir das entrevistas

Da análise do caso depreende-se que o alinhamento com as demais estratégias corporativas se dá em três esferas: no Conselho de Administração que é quem dá as orientações para todas as estratégias das empresas do Grupo, incluindo as socioambientais; no Fórum de Amigos da Sustentabilidade, onde estão presentes tomadores de decisão de todas as empresas do Grupo e representantes da área de planejamento estratégico da "MQ"; e nas empresas do Grupo que são as responsáveis pela consolidação das diretrizes estratégicas feitas pela "MQ" e materialização destas diretrizes em formulação de estratégias para seus negócios.

Com relação a como as externalidades ambientais negativas são consideradas no processo de formulação estratégica socioambiental da "MQ" cabe destacar os seguintes pontos:

- As únicas estratégias formais e públicas para sustentabilidade do Grupo "MQ" tratam dos temas Carbono e Amazônia. Para estes temas, o Grupo parece ter estratégias formais e claras. Já outros temas afeitos à sustentabilidade (impacto dos negócios do Grupo sobre os recursos hídricos, por exemplo), foram pouco citados nas entrevistas. Carbono e Amazônia aparecem nas entrevistas como "os" temas fundamentais para as estratégias para a sustentabilidade do "MQ"; 
- Ficou claro durante as entrevistas que emissões de gases de efeito estufa formam um tema que representa uma exposição ao risco para o Grupo, já que $80 \%$ das emissões de gases de efeito estufa do Grupo estão concentradas nos negócios de cimento e construção civil. Cabe ressaltar que estes negócios representaram em 2010, juntos, $48 \%$ da receita líquida do Grupo, ou seja, são negócios cujos desempenhos têm impacto relevante sobre o desempenho do Grupo como um todo. Como ainda são incertas as medidas que serão tomadas nos níveis municipal, estadual, nacional e internacional relacionadas à internalização da externalidade emissões de gases de efeito estufa, parece claro que o Grupo se antecipou ao risco que esta externalidade pode representar em termos de impactos econômico-financeiros, tais como, investimentos necessários na produção para redução de emissões de gases de efeito estufa, taxas e impostos sobre carbono, barreiras não tarifárias em mercados onde a questão das mudanças climáticas esteja mais avançada, entre outros. No Brasil, em nível Federal, a Política Nacional sobre Mudança do Clima sinaliza que futuros decretos detalharão as ações necessárias para que seus os objetivos sejam alcançados. Vale destacar ainda, que emissões de gases de efeito estufa estão ligados a serviços ecossistêmicos de regulação, fundamental para a sustentação da vida na Terra;

- Com relação ao tema Amazônia parece também clara e direta a relação com os negócios do Grupo. Como expresso pelo Diretor de Sustentabilidade da "MQ": "Nos próximos 20 anos, $80 \%$ da receita da empresa de construção do Grupo virá de obras na região. Não é mais uma discussão de se vamos para a Amazônia, mas de como vamos." Da análise das Demonstrações Financeiras de 2010 do Grupo conclui-se que os negócios de engenharia e construção respondem, sozinhos, por cerca de 35\% da receita líquida do Grupo. Em 2010, o faturamento líquido destes negócios foi de cerca de R \$6 bilhões; e, portanto, se o patamar de faturamento atual se mantiver nos próximos 20 anos, $\mathrm{R} \$ 4,8$ bilhões de faturamento por ano virão de operações na Amazônia. Portanto, é possível concluir que ter uma estratégia clara de gestão socioambiental para a Amazônia, neste caso, está claramente vinculado à competitividade do negócio e a minimizar riscos e maximizar oportunidades. Em especial considerando os seguintes aspectos:

- Em 2011, a empresa de construção do Grupo se viu envolvida em um episódio de revolta e conflito com os trabalhadores de uma obra na Amazônia. O acontecimento causou um prejuízo considerável ao Grupo, segundo o Gerente de Sustentabilidade de 
"milhões de reais" já que não apenas as obras foram paralisadas, como foram necessários recursos financeiros para lidar com esta crise;

- Obras de infraestrutura na região Amazônica, como as Usinas Hidrelétricas do Rio Madeira e de Belo Monte no rio Xingu, apenas para citar algumas, têm sido alvo de controvérsias e de discussões na sociedade a respeito dos impactos socioambientais que podem causar (SEVÁ FILHO, 2005). Portanto, tendo em vista a complexidade dos desafios socioambientais na região, formular estratégias específicas para ela impacta diretamente a competitividade de um relevante negócio do Grupo.

- A frase dita pelo Diretor da área de sustentabilidade: “Em 2008, a nossa Presidente sentiu a necessidade de traduzir as questões de sustentabilidade em uma linguagem mais próxima dos negócios, de forma mais gráfica" ilustra o movimento da "MQ" no sentido de tornar as estratégias de sustentabilidade mais próximas do negócio, de organizar o processo de análise estratégica da sustentabilidade com o desenvolvimento de instrumentos que permitam seleção e priorização de maneira objetiva e racional dos aspectos socioambientais a serem tratados no processo estratégico. Neste sentido, a equipe de sustentabilidade desenvolveu a ferramenta "nível de sustentabilidade" fortemente amparada em referências externas tais como GRI, o Guia da Boa Cidadania Corporativa da Revista Exame, e os questionários de índices de sustentabilidade da Bolsa de Valores de São Paulo e o da Bolsa de Valores de Nova Iorque. Sem dúvida, esta ferramenta parece estar contribuindo para o processo de gestão estratégica da sustentabilidade - foi mencionado nas entrevistas que as empresas do Grupo se apóiam nesta ferramenta para tomar suas decisões estratégicas de cunho socioambiental, como ilustrado pelo exemplo da área de suprimentos de uma das empresas pertencentes ao Grupo que, ao analisar seu desempenho no "nível de sustentabilidade", considerou que seria importante desenvolver um projeto para uma "cadeia de suprimentos sustentável". Entretanto, é uma ferramenta que não parece favorecer a análise dos impactos acumulados - e a relação entre estes impactos - dos negócios do Grupo, em especial quando se considera a dinâmica espacial $^{11}$. É importante que a análise das externalidades considere os impactos particularizados geograficamente, porque externalidades ambientais negativas podem ser bastante diversas considerando-se as diferentes regiões e geografias em que os negócios se localizam. Além disso, externalidades que eventualmente possam parecer pouco relevantes

\footnotetext{
${ }^{11}$ Ver Apêndice II para definição.
} 
quando analisadas de forma isolada (por exemplo, uma usina hidrelétrica em um determinado local da Amazônia), podem se tornar materiais ao se considerar os impactos acumulados de diversos negócios e a relação cruzada entre estes impactos (por exemplo, três usinas hidrelétricas, uma estrada, uma usina siderúrgica, uma fábrica de cimento, no mesmo local da Amazônia. Se cada empresa - a de energia, a engenharia e construção, a siderúrgica, a de cimento - analisarem suas externalidades ambientais negativas isoladamente, talvez cheguem à conclusão que não são tão relevantes assim. Mas, ao analisar os impactos acumulados destas externalidades, talvez a conclusão seja diferente. A análise dos impactos acumulados, em tese, estaria no escopo de atuação da "MQ"). Cabe também destacar o comentário do Diretor de Sustentabilidade sobre uma das empresas do Grupo que, segundo ele, "[...] está me "enrolando" para iniciar o processo de inventário de gases de efeito estufa, apesar de estar aprovado em orçamento." Isto porque, na avaliação da empresa, a externalidade ambiental negativa que considera realmente importante é (nas palavras do Diretor), o consumo de água. Ora, a análise da empresa aponta que, em sua cadeia de valor, a externalidade ambiental negativa material é o consumo de água, embora a visão da holding seja a de que emissões gases de efeito estufa componham a grande externalidade, para todas as empresas, em todas as regiões, em todo o espaço de tempo analisado. Pode ser que seja assim - é impossível saber sem uma análise mais aprofundada -, mas a solução inovadora e a ação imediata postas em práticas pela empresa "rebelde" mostram que talvez haja um ruído no processo de estabelecimento de prioridades ambientais no âmbito das estratégias de sustentabilidade da holding;

- O desenvolvimento da ferramenta de avaliação de impactos socioambientais nos processos de investimento exemplifica a importância atribuída pela organização ao processo de racionalizar e tornar objetivas as análises de aspectos socioambientais, inclusive para a valoração em suas estimativas orçamentárias. Esta ferramenta significa um grande avanço no sentido de identificar externalidades e fazer gestão de risco socioambiental. A consideração de um nível mínimo de atuação socioambiental que todas as empresas do Grupo precisam observar em seus processos de investimento - mesmo que as leis e regulações locais sejam menos exigentes que este nível mínimo - é um avanço importante especialmente considerando o amplo escopo geográfico de atuação do Grupo. Entretanto, embora pareça que a ferramenta em desenvolvimento pela "MQ" vá contribuir para a formulação e priorização de estratégias socioambientais - já que atribui níveis de adequação à sustentabilidade e 
investimentos associados a melhorias socioambientais - tem um caráter estático, não considerando impactos acumulados e questões relacionadas aos custos externos impostos pela cadeia de valor não aparecem com muita ênfase e sim, de forma indireta.

- Ao longo das entrevistas foi pouco mencionado o engajamento de stakeholders, e quando o foi, pareceu que a comunicação com stakeholders é prioritariamente de mão única, da empresa para o stakeholder. A análise de interdependência dos negócios com a sociedade (aqui incluindo a questão ambiental) é de tamanha complexidade que sem a contribuição de stakeholders-chave, a identificação e gestão dos custos externos que um negócio impõe à sociedade é impossível. Stakeholders são, portanto, elementos fundamentais para um processo estratégico de sustentabilidade que pretenda gerar valor para a competitividade da organização, identificando riscos e oportunidades. E neste sentido, é preciso haver diálogo (mão dupla), parcerias que vão no sentido da construção conjunta de negócios que imponham menos custos externos à sociedade.

\section{$* * *$}

Da análise do caso, parece evidente que o processo de formulação das estratégias para a sustentabilidade da "MQ" considera as externalidades ambientais negativas, especialmente a partir de 2006, de maneira indireta, com potencial para maiores formalização e particularização às diferentes realidades dos negócios do Grupo.

Entretanto, amparada largamente em questionários externos - apesar de customizado para as empresas do Grupo por meio da ferramenta "nível de sustentabilidade"-, o processo de formulação das estratégias para a sustentabilidade da "MQ" não parece considerar com profundidade o impacto negativo (que é o tema desta tese) de seus negócios para a sociedade, ou para usar o termo proposto por Ansoff e McDonnell (1993) "subprodutos negativos das atividades empresariais privadas".

Ainda que as estratégias relacionadas às maiores externalidades ambientais negativas estejam concentradas nas empresas que compõem o Grupo (e que não foram objeto deste estudo de caso), parece que há espaço para que a holding aprimore o processo de formulação de estratégias para a sustentabilidade ao considerar em maior profundidade a extensão dos custos externos ambientais que seus negócios combinados impõem à sociedade, em especial quando 
a principal estratégia para um de seus negócios mais relevantes está concentrada em expandir para a Amazônia, região de imensa complexidade ambiental e social.

\subsection{Estudo de caso: a empresa "Cecília Meireles"}

Reinvenção

A vida só é possível reinventada.

Anda o sol pelas campinas e passeia a mão dourada pelas águas, pelas folhas... Ah! tudo bolhas que vem de fundas piscinas de ilusionismo... - mais nada.

Mas a vida, a vida, a vida, a vida só é possível reinventada.

(Cecília Meireles)

Para a realização deste caso foram realizados encontros com o Diretor da área de Sustentabilidade da empresa, ao longo de um ano. O Diretor tem formação em Engenharia, com pós-graduação lato sensu em Gestão e pós-graduação stricto sensu (doutorado) em Engenharia, com foco em sustentabilidade. Está na empresa há mais de vinte anos.

\subsubsection{Contexto da empresa}

A empresa "Cecília Meireles" tem sua origem na década de 1970. Com a privatização, pelo governo brasileiro, de empresas petroquímicas na década de 1990, a empresa seguiu comprando empresas em um processo de verticalização da produção. Os processos de aquisições e consolidação das aquisições continuaram por toda a década de 1990 até o início da década de 2000, quando a empresa fez a abertura de capital na bolsa de valores de São Paulo e

Box 2: Compromissos externos voluntários

- "CM" é signatária dos seguintes acordos voluntários: Pacto Global, Empresas pelo Clima, Carbon Disclosure Project, Programa Atuação Responsável (iniciativa do Conselho Internacional que representa as indústrias químicas), Declaração Internacional Produção Mais Limpa, Programa Na Mão Certa;

- Compõe a carteira do Índice de Sustentabilidade Empresarial para o ano de 2012.

Fontes: Relatório Anual, 2010 e website 
estreou na Bolsa de Nova Iorque, já na configuração atual, com os ativos consolidados.

Atualmente, a empresa está entre as maiores produtoras de resinas termoplásticas do mundo, produzindo insumos básicos para a indústria química tais como eteno, propeno, butadieno,entre outros. A empresa tem unidades produtivas no Brasil (regiões Nordeste, Sul e Sudeste) e nos Estados Unidos. Em 2010, a empresa passou a produzir em escala comercial o polietileno à base de etanol, como parte de sua estratégia de sustentabilidade. Anunciou, também em 2010, o desenvolvimento de uma planta de propeno (30 mil toneladas/ano) à base de etanol de cana-de-açúcar a ser concluída em 2013.

Ao todo, a empresa possui 6.750 funcionários e em 2010, a empresa obteve receita líquida de cerca de $\mathrm{R} \$ 30$ bilhões e lucro líquido de cerca $\mathrm{R} \$ 2$ bilhões. A tabela abaixo apresenta algumas informações financeiras da empresa:

Tabela 3: Informações financeiras selecionadas da empresa "Cecília Meireles":

\begin{tabular}{|l|l|l|}
\hline Em R\$ bilhões & $\mathbf{2 0 1 0}$ & $\mathbf{2 0 0 9}$ \\
\hline Receita líquida & Cerca de 28,0 & Cerca de 23,0 \\
\hline Lucro Líquido & Cerca de 2,0 & Cerca de 0,4 \\
\hline EBITDA & Cerca de 4,0 & Cerca de 3,0 \\
\hline Investimentos & Cerca de 2,0 & Cerca de 0,9 \\
\hline Ativos totais & Cerca de 35,0 & Cerca de 20,0 \\
\hline Patrimônio Líquido & Cerca de 10,0 & Cerca de 5,0 \\
\hline
\end{tabular}

Fonte: Relatório anual, 2010

\subsubsection{Visão e valores}

O ano de 2010 marca a redefinição de sua visão corporativa de forma a expressar, explícita e formalmente, seu compromisso com a sustentabilidade. São os valores e princípios que orientam a organização: (i) a satisfação do cliente, servindo-o com qualidade, produtividade e responsabilidade econômica, social e ambiental; (ii) atuação responsável, em linha com as premissas do desenvolvimento sustentável, baseada na preservação da saúde e segurança das pessoas, assim como do meio ambiente; (iii) confiança nas pessoas, em sua capacidade e desejo de evoluir; (iv) autodesenvolvimento das pessoas sobretudo pela educação pelo e para 
o trabalho, gerando desenvolvimento para a empresa; (v) atuação descentralizada, com base na delegação plena e planejada para que os funcionários atuem com liberdade e responsabilidade; (vi) reinvestimentos para criação de novas oportunidades de trabalho e de desenvolvimento da sociedade; (vii) retorno do capital investido aos acionistas e investidores.

Sua estratégia para 2020 é ser reconhecida como uma empresa líder em sustentabilidade no setor químico, com o foco no atendimento das necessidades humanas. São três os caminhos que a empresa entende serem necessários para o atingimento desta estratégia: (i) fortalecer sua carteira de produtos de forma a torná-la cada vez mais sustentável, ampliando, por exemplo, a participação dos produtos a partir de matéria-prima renovável; (ii) desenvolver, por meio de pesquisa e inovação, resinas ainda mais úteis, destinadas a novas aplicações de produtos plásticos que contribuam para a qualidade de vida e a sustentabilidade; (iii) investir na ecoeficiência de suas operações.

\subsubsection{Estratégia para a sustentabilidade}

A história da gestão para sustentabilidade na "CM" tem seu embrião na gestão de Saúde, Segurança e Meio-Ambiente (SSMA), presente na empresa desde sua origem, assim como as atividades de responsabilidade social corporativa. Em função do "aquecimento" do debate sobre sustentabilidade, em 2009 a empresa decidiu criar uma Diretoria de Sustentabilidade, dentro da Vice-Presidência de Relações Institucionais e Marketing, passando a área de SSMA e as atividades de responsabilidade social a integrar esta nova Diretoria. Assim, a nova área assumiria não apenas a gestão da área de SSMA (bastante vinculada à produção), mas também a tarefa de fomentar o desenvolvimento de uma estratégia socioambiental ampla e de mais longo prazo, indo para além dos muros da empresa. A área de sustentabilidade passou então a gerir os temas de SSMA e responsabilidade social corporativa e a pensar nas estratégias que envolvessem aspectos socioambientais na cadeia de valor. A Diretoria de Sustentabilidade da "CM" é composta por treze pessoas: um Diretor, um gerente, um coordenador e dez analistas com diferentes níveis de senioridade e responsabilidade.

As macros linhas de atuação de "CM" em gestão para sustentabilidade são: (i) conduzir o processo estratégico de sustentabilidade da companhia influenciando - por meio de estudos e pesquisas - a inclusão desta estratégia nas demais áreas de negócios da companhia; (ii) apoio 
às áreas de negócios em sua relação com stakeholders externos afeitos ao tema; (iii) gestão da área de Saúde, Segurança e Meio Ambiente em alinhamento matricial com as áreas de negócios. A área de SSMA tem a parceria da Diretoria de Sustentabilidade e responde aos diretores das áreas de negócios. Um exemplo: a área de SSMA lotada em uma planta de polietileno responde ao diretor industrial da planta e tem o apoio e alinha-se ao diretor de sustentabilidade; (iv) definição das estratégias de responsabilidade social em alinhamento matricial com a área de relacionamento institucional (v) interlocução com stakeholders externos quanto aos temas afeitos à sustentabilidade; (vi) fomento à formação de competências em temas afeitos à sustentabilidade.

4.2.4 O processo de formulação das estratégias para a sustentabilidade e o diálogo com a formulação das demais estratégias

O processo de formulação das estratégias para a sustentabilidade se dá mais fortemente com a equipe da área de sustentabilidade. A "CM" é uma empresa com uma cultura muito forte de autonomia e dinamismo. As áreas de negócios são as responsáveis pela definição das estratégias de negócios, mas são influenciadas pelas discussões com a área de sustentabilidade. Por sua vez, a equipe de sustentabilidade, a partir de análises internas e externas, identifica os principais gargalos e pontos de atenção quanto à questão socioambiental.

A análise interna tem como principal fonte as questões relacionadas à SSMA, em especial ecoeficiência e os compromissos assumidos pela organização com relação a este tema. As análises externas levam em conta sua cadeia de valor.

A empresa "CM" é uma organização com culturas distintas quanto a processos: as áreas industriais têm processos bem definidos; já as áreas administrativas e de apoio não priorizam processos. Para as áreas de apoio, a cultura corporativa privilegia pessoas, mais especificamente, um documento preparado por cada funcionário individualmente (chamado de "plano de trabalho ${ }^{12 »)}$ e acordado com as chefias e com outras áreas intervenientes da empresa; em alguns casos, estes planos de trabalho podem ser acordados com stakeholders externos. Estes planos de trabalho são a base para quaisquer decisões e ações que os

\footnotetext{
${ }^{12}$ Nome trocado para assegurar a confidencialidade.
} 
funcionários tomam, e têm, com maior frequência, um horizonte temporal de planejamento de um ano; em alguns casos, dependendo da natureza da área e dos desafios, podem ter metas para mais de um ano. Esta descrição da cultura organizacional é importante porque estabelece o pano de fundo sobre o qual poderá ser analisado o processo de formulação de estratégias para a sustentabilidade da "CM". De uma forma sucinta, o desafio da equipe de sustentabilidade da"CM" é influenciar as áreas de negócios e demais áreas da empresa que tenham conexão com aspectos socioambientais a incluírem estes aspectos em seus planos de trabalho durante seu planejamento estratégico para o ano seguinte. Uma vez que os planos de trabalho individuais tenham sido acordados entre funcionários e chefia é improvável que venham a ser alterados (improvável, mas não impossível, já que se as pessoas forem convencidas da importância da mudança, esta pode acontecer).

Cabe ressaltar que a remuneração variável de todos os funcionários está atrelada ao cumprimento de seu plano de trabalho. Portanto, a essência do processo de gestão da "CM" está vinculada ao planejamento e execução dos planos de trabalho individuais e coletivos das áreas. Desta forma, a área de sustentabilidade se preocupa bastante em antecipar análises e estudos de questões socioambientais de forma a estar preparada para iniciar seu processo de influência quando o ciclo de planejamento das diversas áreas da empresa se iniciar.

\section{- O ciclo de planejamento estratégico}

A área corporativa de planejamento estratégico envia a todas as áreas da empresa as grandes diretrizes corporativas (que vêm da alta administração), envolvendo informações acerca do volume de produção projetado para o ano seguinte, mercados a serem atingidos, projeções macroeconômicas, entre outros dados relevantes para que as áreas realizem suas projeções, perspectivas e principalmente, proponham o orçamento. Por essa razão, este momento representa uma "janela de oportunidade" para a equipe de sustentabilidade porque o que não for incluído no orçamento que será aprovado pela alta administração, dificilmente será executado. Os produtos da "CM" são, em sua maior parte, commodities, e portanto, o controle de custos na organização é rígido. Os gestores têm bastante autonomia para propor o plano de trabalho para área (que se desdobrará no plano de trabalho individual dos funcionários da área) e o orçamento que o torna viável. Uma vez aprovado, o plano de trabalho e orçamento são executados com relativa autonomia. Não é bem-vista a inclusão de novos itens no 
orçamento além daquilo que foi previsto - podendo, inclusive, penalizar a remuneração variável dos profissionais da área. Também não é bem-vista a não execução de parte do orçamento aprovado (subutilizando os recursos financeiros) - significa que recursos financeiros foram alocados para aquela área que não soube "fazer bom uso".

Quando o ciclo de planejamento se inicia (normalmente no terceiro ou quarto trimestre do ano), as áreas fazem oficinas de planejamento, convidando não apenas seus funcionários (é um planejamento participativo), mas também funcionários de outras áreas da empresa que impactam ou demandam o desempenho da área. Convidam também pessoas de fora da empresa: professores, jornalistas, fornecedores, clientes, enfim, quaisquer pessoas que possam contribuir para um bom planejamento da área. É neste momento que a área de sustentabilidade pode influenciar as demais áreas da empresa. Munidos de análises e propostas, membros da equipe de sustentabilidade participam destes eventos internos, propondo pautas para o plano de ação da área para cujo planejamento foi convidado. Ressaltando que a área de sustentabilidade precisa fazer seu próprio planejamento e assim, convidar participantes de outras áreas da empresa, em um processo similar.

O processo de construção da estratégia para 2020 da empresa é um exemplo de como a formulação de estratégias de sustentabilidade influencia a estratégia corporativa. Em 2009, quando a área de sustentabilidade foi oficialmente criada, uma das primeiras tarefas da área foi montar um plano estratégico para a área. A principal questão orientadora nesta fase foi: "em que aspectos sociais e ambientais deveríamos orientar a nossa atuação estratégica para os próximos dez anos?”

A equipe seguiu então os seguintes passos:

- Realizou pesquisas com base em dados secundários para identificar as principais questões de "estado do mundo" para os próximos dez anos, as pressões externas que, provavelmente, impactarão os negócios da empresa: relatórios de consultorias, de organizações nacionais e internacionais da indústria química, pesquisas acadêmicas, artigos de jornais e revistas, entre outros;

- Conversou com gestores das áreas de negócios para identificar os principais desafios socioambientais em suas áreas de negócios. Por exemplo: o gestor do produto polietileno a 
base de etanol de cana-de-açúcar precisaria apresentar o estudo da análise de ciclo de vida de seu produto para clientes externos, de forma a argumentar racionalmente que este produto é mais eficiente em carbono que o produto feito pela rota tradicional (nafta). Por esta e outras demandas das áreas, gestão do carbono, portanto, foi considerado um tema crucial para a organização;

- Refletiu sobre suas próprias análises acerca dos principais riscos e oportunidades envolvendo aspectos socioambientais na empresa; em outras palavras, as pressões internas à empresa, incluindo os compromissos voluntários assumidos pela organização, que foram considerados no processo estratégico.

A partir destas análises, o grupo passou a sistematizar os resultados, usando como referência o guia de reporte para a sustentabilidade do Global Reporting Initiative, gerando uma matriz estratégica de impactos que teve por objetivo priorizar os aspectos socioambientais mais relevantes para a empresa.

A figura a seguir ilustra o resultado da análise do grupo: 
Figura 18: Análise da relevância dos aspectos socioambientais selecionados com base no GRI:

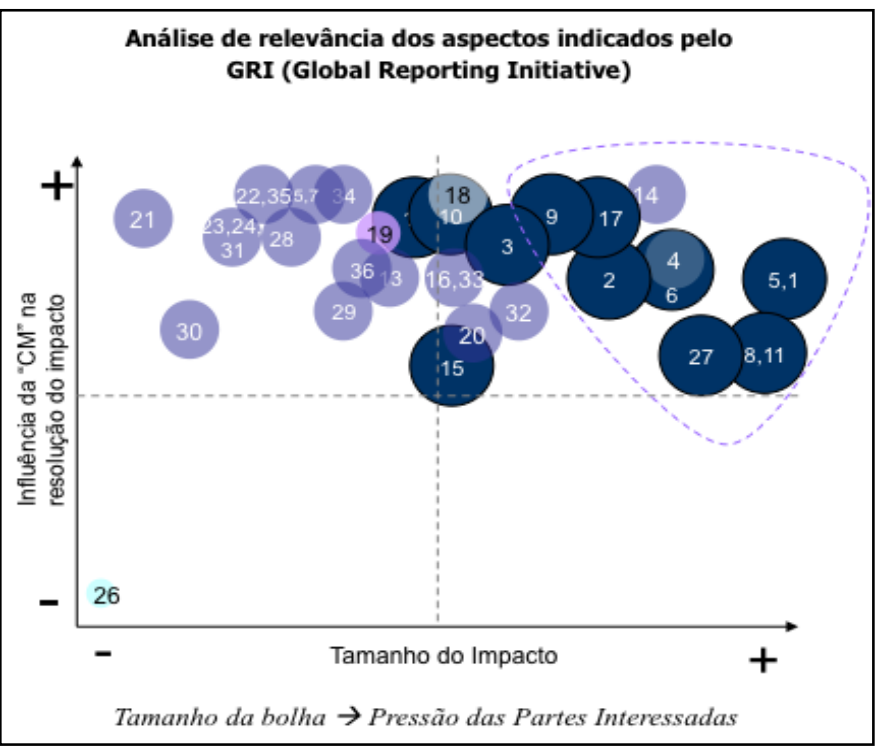

Fonte: adaptado de relatório interno da empresa
A partir desta análise, a empresa priorizou os impactos no extremo do quadrante superior direito. Isto porque dada a limitação de recursos financeiros e humanos, foi necessário priorizar as estratégias socioambientais. Na sequência, a equipe de sustentabilidade elencou onze aspectos prioritários e destes, sete elementos-chave de sua estratégia de sustentabilidade: (i) alta eficiência no uso
- A coordenada horizontal representa o impacto que a empresa tem sobre aquele determinado aspecto;

- A coordenada vertical representa a influência que a empresa tem em resolver problemas socioambientais (exemplo: a influência que a empresa tem em resolver o problema da fome no mundo é limitada; mas a influência que tem em resolver o problema de emissões em municípios próximos às suas plantas é grande);

- O tamanho das bolhas coloridas representa a pressão externa (dos stakeholders) sobre cada um dos aspectos;

- As diferentes cores das bolhas representam os diferentes tamanhos de bolhas: azul escuro, grande; violeta, médio, azul claro, pequeno.

- Os números fazem referência aos aspectos listados pelo GRI: 1- desempenho econômico; 2- presença de mercado; 3 - impacto econômico direto; 4 - uso de materiais; 5 - uso de energia; 6 - uso de água; 7 - biodiversidade; 8 - emissões atmosféricas; 9 efluentes; 10 - resíduos; 11 - impactos de produtos e serviços; 12 - conformidade ambiental; 13 impactos de transporte; 14 - investimentos em meio ambiente; 15 - emprego; 16 - negociações coletivas; 17 - saúde e segurança do trabalho; 18 treinamento e educação; 19 - igualdade de oportunidades; 20 - investimentos e compras; 21 não-discriminação; 22 - liberdade de associação; 23 - trabalho infantil; 24 - trabalho forçado; 25 segurança empresarial; 26 - direitos indígenas; 27 - comunidades; 28 - corrupção; 29 - políticas públicas; 30 - concorrência desleal; 31 conformidade legal; 32 - saúde e segurança do cliente; 33 - rotulagem do produto; 34 marketing; 35 - privacidade do cliente; 36 conformidade relativa ao fornecimento e uso de produtos da empresa.

dos recursos hídricos, reutilizando $100 \%$ da água nas localidades que enfrentam stress hídrico; (ii) avanço no uso de matérias-primas renováveis, tornando-se a líder na produção de biopolímeros; (iii) apoio à reciclagem de produtos plásticos - foco estratégico no pós consumo do plástico, incluindo apoio ao desenvolvimento da reciclagem energética; (iv) gestão do carbono com vistas à redução das emissões de gases de efeito estufa por tonelada de produto e tornar-se importante sequestrador de gases de efeito estufa pelo uso de matérias- 
primas renováveis; (v) avanços na produção responsável de produtos químicos (segurança química), e não utilização nem produção de substâncias incluídas em listas globais de banimento; (vi) aumento da eficiência energética, alcançando a mesma quantidade de consumo de energia por tonelada de produto das melhores empresas químicas do mundo e migrando seu consumo de energia elétrica para energias renováveis (vii) contribuição para melhoria do desenvolvimento humano e reconhecimento da empresa como um dos melhores lugares para se trabalhar.

Para cada um destes sete elementos, foram levantadas iniciativas para os próximos dez anos, assim como orçamento necessário para que se concretizem.

Até este momento, esta formulação estratégica estava restrita à área de sustentabilidade. De posse destas análise, a equipe passou a agir ativamente para influenciar o processo estratégico em nível corporativo junto à área de planejamento estratégico e junto às áreas de negócios. Como resultado, a estratégia para 2020 da empresa foi revista e foram incorporados os elementos-chave na estratégia geral da companhia, com desdobramentos para todas as áreas da empresa.

\subsubsection{Reflexões e interpretações dos dados levantados}

O processo de formulação de estratégias para sustentabilidade da empresa "CM" pode ser subdivido em dois: (i) a formulação das estratégias para a própria área de sustentabilidade, particularmente no que tange a gestão de Saúde, Segurança e Meio Ambiente; e (ii) o processo de influência na formulação da estratégia global da companhia e das demais áreas de apoio (como Marketing, Recursos Humanos, Finanças, Novos Negócios etc) e áreas de negócios ( Comercial Polietileno, Comercial Polipropileno, Produção Polietileno etc). Estes dois aspectos dialogam com maior intensidade quando da formulação da estratégia global da companhia, uma vez ao ano, no chamado "ciclo de planejamento". Como resultado das discussões no ciclo de planejamento, cada área - e a companhia como um todo - passa a ter um plano para o próximo ano, vinculado a um orçamento. O horizonte temporal deste processo é tipicamente de um ano, exceto para o Presidente, cujo plano é plurianual, para os próximos cinco anos. Entretanto, em 2010 a empresa se engajou em um processo de planejamento estratégico para os próximos dez anos, para a construção de sua estratégia para 
2020. O processo seguiu a mesma lógica do planejamento anual, porém, o "lobby" da área de sustentabilidade teve de ser mais intenso, já que o resultado deste planejamento estratégico guiará a construção da agenda de sustentabilidade da companhia pelos próximos dez anos.

A figura abaixo sintetiza o processo de formulação das estratégias de sustentabilidade da empresa:

Figura 19: Fluxo simplificado do processo de formulação estratégica para sustentabilidade da empresa "CM":

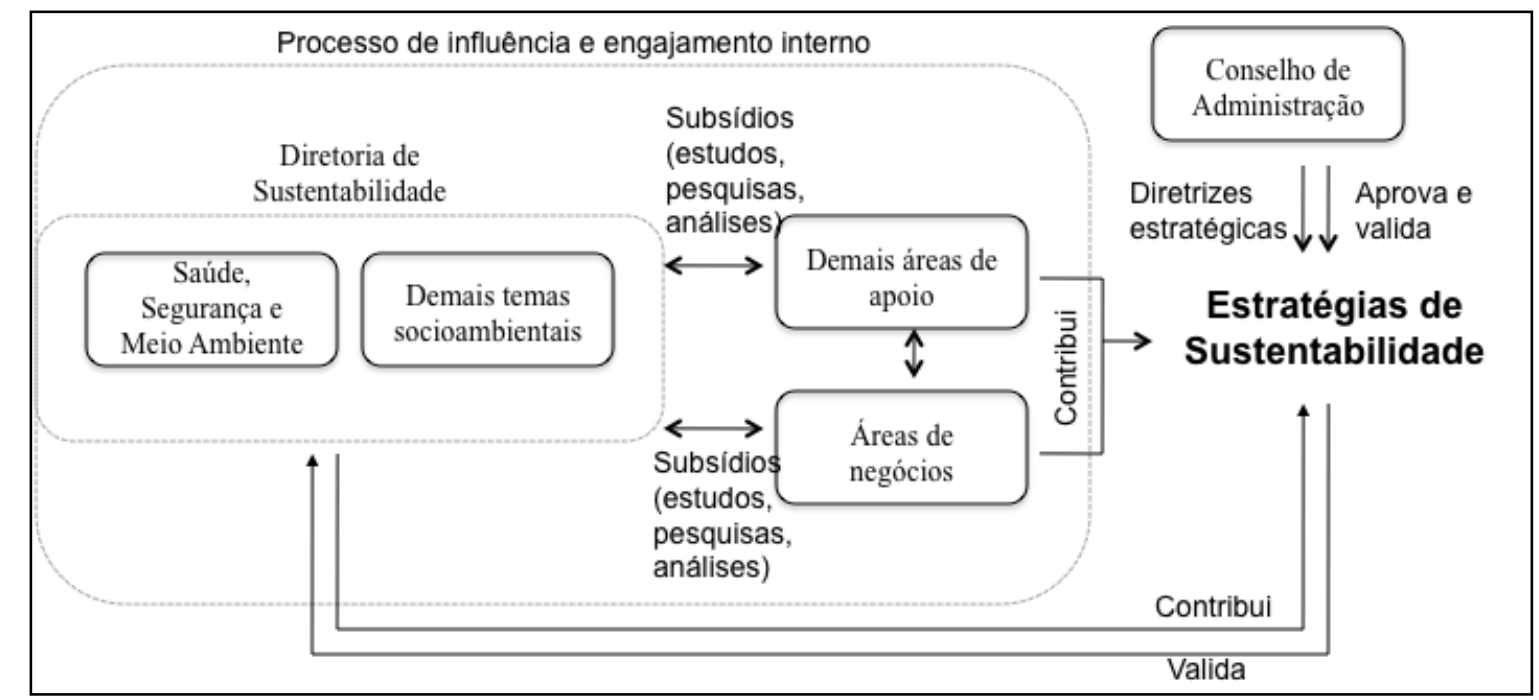

Fonte: elaboração própria a partir das entrevistas

Com relação a como as externalidades ambientais negativas são consideradas no processo de formulação estratégica socioambiental da "CM" cabe destacar os seguintes pontos depreendidos a partir do conteúdo das entrevistas e da análise de dados secundários:

- Fica evidente da análise do caso que a empresa se caracteriza por um grande dinamismo em seu sistema de gestão. Soa um tanto dissonante falar em "processo de formulação de estratégias para sustentabilidade" para a "CM" já que o dinamismo característico de sua cultura organizacional coloca menor ênfase no processo e maior no relacionamento entre as pessoas, em especial para aquelas questões socioambientais que não estão diretamente relacionadas à produção, onde a necessidade de existência de processos é inquestionável. Ainda assim, uma organização deste porte precisa de subsídios para seu processo de formulação estratégica e tomada de decisão, e isso parece ainda mais aplicável à realidade da área de sustentabilidade desta empresa, que tem papel mais influenciador e menos de tomador de decisão na linha de frente dos negócios; 
- Isto posto, o processo de construção da estratégia anual parece considerar as externalidades ambientais negativas geradas pela organização ao longo de sua cadeia de valor; mas, parece um processo mais voltado a resolver os problemas mais imediatos - aqueles mais evidentes no horizonte. Parece que há espaço para a área de sustentabilidade da "CM" ampliar seu olhar para os impactos socioambientais negativos, no sentido de contribuir para que a empresa tenha sua competitividade de longo prazo assegurada, antecipando riscos e oportunidades;

- Como exemplo desta reflexão, pode-se citar a campanha contra as sacolinhas de plástico. A empresa não produz as sacolinhas, mas é o principal fornecedor de matéria-prima da cadeia de valor das sacolas plásticas. Em 2009, a empresa e o setor foram surpreendidos pela campanha "Saco é um saco: Pra cidade, pro planeta, pro futuro e pra você", coordenada pelo Ministério do Meio Ambiente, com apoio de empresas privadas, como Carrefour, Wal-Mart Brasil, CPFL Energia, Vivo, Kimberly-Clark Brasil, Gol, Rain e atores sociais como AfroReggae, Instituto Akatu, WWF Brasil, Revista Eco 21, Confederação Nacional dos Transportes. A campanha, largamente divulgada nos meios de comunicação de massa, advertia quanto ao uso excessivo das sacolinhas plásticas e o dano que causam ao meio-ambiente sobretudo pelo descarte inadequado, impactando rios, cursos d'água, bueiros etc. A campanha gerou ampla mobilização nacional e como resultado, diversas capitais brasileiras discutem leis que limitam ou proíbem a utilização de sacolas plásticas em estabelecimentos comerciais. (O GLOBO, 2011) A tônica da campanha recaiu sobre os potenciais malefícios do plástico: sua impermeabilidade e o fato de que causa a impermeabilidade e a compactação do solo, dificultando a biodegradação dos resíduos orgânicos presentes nos lixões e aterros, favorecendo a incidência de bolsões de gás metano que quando liberados na atmosfera contribuem para o chamado efeito estufa. (SACO É UM SACO) A empresa precisou mobilizar recursos humanos e financeiros para responder a esta campanha (ainda que de maneira incógnita, apoiando a resposta à campanha por meio da associação de classe do setor), para proteger seus clientes - os chamados "sacoleiros", produtores de sacolinhas - e para iniciar um processo de "blindagem" do plástico que, em razão da campanha, tem sido mais acentuadamente noticiado como um importante "vilão" da sustentabilidade. Entretanto, limites ao uso de sacolinhas plásticas não chegam a ser novidade: países desenvolvidos e em desenvolvimento já implantaram políticas públicas similares, como Irlanda e Bangladesh em 2002, China em 2008, apenas para citar alguns (SACO É UM SACO; EARTH RESOURCES FoundATION). Assim, parece que a empresa foi surpreendida pela força da mobilização 
social contra as sacolas plásticas (e o plástico, em menor medida); este fato demonstra que seu impacto ambiental negativo sobre a sociedade poderia ser melhor monitorado em seus radares estratégicos, especialmente para temas (plástico, pós consumo, resíduos urbanos) muito afeitos à sustentabilidade ${ }^{13}$.

- No entanto, como resultado de sua cultura dinâmica, a empresa rapidamente incorporou estes impactos em seu planejamento estratégico de longo prazo. Um dos sete elementos da estratégia para 2020 é justamente o apoio à reciclagem de produtos plásticos, incluindo o apoio ao desenvolvimento da reciclagem energética no Brasil. Esta é uma meta que não depende unicamente da organização, mas de um engajamento desta com outros atores sociais, como instituições governamentais e do terceiro setor, construção de políticas públicas e outras empresas privadas engajadas no mesmo tema. Este objetivo estratégico aponta claramente para a consideração explícita de uma externalidade ambiental negativa no processo estratégico - as sacolas plásticas que estão presentes na cadeia de valor da "CM". Estivesse a "CM" unicamente preocupada com suas próprias atividades produtivas contidas dentro de seus muros, provavelmente esta meta não comporia sua estratégia. A decisão de se engajar em um esforço social mais amplo no desenvolvimento de soluções que visem à diminuir o problema do descarte inadequado das sacolas plásticas e na reciclagem energética do plástico, demonstra claramente que a empresa considera estas ações relevantes para seu negócio;

- Neste mesmo contexto, podem ser analisados outros elementos -chave da estratégia:

- A empresa considera um elemento-chave a busca pela eficiência no uso de recursos hídricos, visando reciclar $100 \%$ da água utilizadas nas plantas que estão localizadas em municípios que enfrentam stress hídrico. Este elemento está alinhado às discussões sobre deslocamento do uso da água de consumo humano para consumo industrial. A empresa concluiu que está presente em localidades que sofrem escassez de água e, portanto, a definição de um elemento que se compromete a considerar este aspecto quando das decisões estratégicas da companhia, de novo, demonstra alinhamento com o conceito de custo externo ambiental que suas atividades impõem à sociedade;

\footnotetext{
${ }^{13}$ Cabe destacar que o setor, por meio do Instituto Sócio-Ambiental do Plástico, a Plastivida, iniciou, em 2008, o Programa de Qualidade e Consumo Responsável de Sacolas Plásticas, que tem por objetivo reduzir em 30\% o desperdício da quantidade de sacolas plásticas distribuídas pelo varejo, por meio do fomento à fabricação de sacolas plásticas mais resistentes, certificadas pela Norma ABNT 14937. (PLASTIVIDA)
} 
- O mesmo se aplica aos demais elementos, todos eles relacionados, em menor ou maior grau, à ideia de custo externo ambiental que as atividades da organização impõem à sociedade.

- Os elementos da estratégias da "CM" têm naturezas predominantemente mais ambientais que sociais; entretanto, é possível enxergar inter-relações entre aspectos econômicos, sociais e ambientais. O elemento de reciclagem do plástico, por exemplo, trata de um aspecto predominantemente ambiental, mas há questões sociais relevantes envolvidas: estimativas do Ministério de Desenvolvimento Social e Combate à Fome apontam para um número de catadores no Brasil da ordem de 300 mil a 1 milhão de pessoas. (MDS) Ou seja, a empresa certamente terá que lidar com aspectos sociais ao operacionalizar este elemento de sua visão. Analogamente, o elemento ligado à reciclagem de água em localidades com stress hídrico traz em sua essência um compromisso social ligado ao desenvolvimento humano, já que a água é fundamental para tal;

- Historicamente, o setor químico esteve envolvido em acidentes com grande número de fatalidades, como aponta a lista de acidentes com mais de vinte mortes na indústria química preparada por Souza (2000); também, trata-se de um setor que é constantemente questionado quanto ao uso de substâncias que podem causar doenças severas aos trabalhadores e aos consumidores (como as discussões quanto aos poluentes persistentes como o Bisfenol-A). Portanto, ao considerar em suas estratégias de sustentabilidade a produção responsável de produtos químicos (segurança química), a "CM" parece buscar responder a estes questionamentos sociais quanto a importantes externalidades negativas. Tais externalidades são difíceis de serem classificadas como ambientais, sociais ou econômicas já que claramente estão relacionadas às três dimensões;

- O setor químico vem se articulando em suas entidades de classe internacional (o International Council of Chemical Associations - ICCA) e nacional (Associação Brasileira da Indústria Química - ABIQUIM) para a incorporação de questões socioambientais na gestão do negócio, como um processo de adaptação às fortes pressões sociais e políticas que agem sobre o setor especialmente após os acidentes e vazamentos ocorridos nas décadas de 1970 e 1980 . Este processo teve início em 1985, quando foi lançado pela Associação das Indústrias Químicas Canadenses uma iniciativa para a melhoria constante no desempenho das áreas de saúde, segurança e meio-ambiente das indústrias químicas canadenses associadas à 
instituição, bem como o estímulo a um processo de comunicação mais transparente com seus stakeholders. Esta iniciativa foi revista e levada a nível global pelo ICCA em 2006 com o nome de "Responsible Care" e tem por objetivos focar "em importantes desafios como o desenvolvimento sustentável, gestão efetiva de químicos ao longo de sua cadeia de valor, maior transparência na indústria e harmonização e consistência da iniciativa pelo mundo" (ICCA). Semelhante iniciativa foi lançada pela ABIQUIM em 1992: o programa "Atuação Responsável" que desenha e sistematiza instrumentos para a gestão ambiental, saúde e segurança dos trabalhadores e, mais recentemente, de responsabilidade social. Em 1992, a adesão das empresas ao programa era voluntária e passou a ser obrigatória das associadas da ABIQUIM em 1998 (SoAReS, DEMAJOROVIC, 2006). No campo legal, cabe destacar a regulação da comunidade européia para a produção e uso de produtos químicos chamada de REACH - Registration, Evaluation, Authorisation and Restriction of Chemical Substances. Esta regulação entrou em vigor em junho de 2007 e tem por objetivo a proteção da saúde humana e do meio-ambiente pela melhor identificação (e mais cedo) das propriedades intrínsecas das substâncias químicas. O surgimento do REACH veio como resposta ao fato de que muitas substâncias químicas são produzidas e comercializadas sem que haja informação suficiente acerca dos riscos que representam para a saúde humana e do meio ambiente (EUROPEAN COMMUNITY). Exportações de produtos químicos para países europeus precisam estar registrados no sistema do REACH. As estratégias de sustentabilidade da "CM" estão alinhadas com as macro-diretrizes para o setor estabelecidas pelas associações nacional e internacional, bem como uma importante regulação européia que trata de segurança química que é o REACH;

- Parece emergir das reflexões acima que a divisão em "triple bottom line" contribui para o processo de formulação das estratégias de sustentabilidade ao alertar os tomadores de decisão que a empresa precisa considerar outros elementos além dos econômico-financeiros nos processos de decisão. Mas parecem ser necessários conceitos complementares que contribuam para instrumentalizar a tomada de decisão, já que há uma grande inter-relação entre os aspectos econômico, social e ambiental. A noção de externalidades, como parece ter sido adotada pela "CM", pareceu contribuir para processo de formulação das estratégias de sustentabilidade na medida em que concentra as atenções das organizações nos impactos que suas atividades causam à sociedade. 
A análise do caso da "CM" aponta para uma grande relação entre o processo de formulação de estratégia da empresa com a noção de externalidades ambientais negativas como fio

condutor deste processo. Cabe ressaltar que seis dos sete elementos-chave da estratégia da empresa estão claramente associados a serviços ecossistêmicos, como o caso das emissões de carbono, consumo de água, segurança química, reciclagem, eficiência energética e uso de matérias-primas renováveis. Parece, então, que a utilização dos conceitos de externalidades ambientais negativas e serviços ecossistêmicos têm alta conexão com o processo de formulação das estratégias de longo prazo de sustentabilidade da empresa. 


\title{
4.3. Estudo de caso: o conglomerado financeiro "Carlos Drummond de Andrade"
}

\author{
Mas se desejarmos fortemente o melhor e, \\ principalmente, lutarmos pelo melhor... \\ O melhor vai se instalar em nossa vida. \\ Porque sou do tamanho daquilo que vejo, \\ e não do tamanho da minha altura. \\ (Carlos Drummond de Andrade)
}

Para a realização deste caso foram realizados encontros e entrevistas com o Diretor e Gerente $^{14}$ da área de sustentabilidade do banco, distribuídos no período de um ano. Em alguns destes encontros e entrevistas, estavam também presentes profissionais do banco da área de crédito (crédito agrícola e grandes obras) e risco. Entretanto, a principal fonte considerada para este estudo foi a área de sustentabilidade. O Diretor tem graduação e pós-graduação lato sensu em Administração de Empresas; está na empresa há mais de cinco anos. O Gerente de sustentabilidade tem formação em Economia e está no banco também há mais de cinco anos.

\subsubsection{Contexto da empresa}

Fundado no início do século XIX, o conglomerado financeiro "Carlos Drummond de Andrade" ("CDA”) é um conglomerado com capital social predominantemente de origem pública, com mais de 100.000 funcionários e presença em mais de quinze países, distribuídos nas Américas e na Europa; atua em sete segmentos: (i) bancário, compreendendo depósitos, operações de crédito, entre outras, voltados ao varejo, atacado e governo. É responsável pela parcela mais significativa dos resultados do banco; (ii) investimentos, incluindo intermediação e distribuição de dívidas nos mercado primário e secundário, bem como em participações acionárias; (iii) gestão de recursos, compreendendo operações de compra, venda e custódia de títulos e valores mobiliários, administração de carteiras, instituição, organização e administração de fundos e clubes de investimento; (iv) seguros,

Box 3: Compromissos externos voluntários

- "CDA" é signatário dos seguintes acordos voluntários: Pacto Global, Empresas pelo Clima, Carbon Disclosure Project, Objetivos do Milênio, Protocolo Verde, Princípios do Equador e Principles for Responsible Investment (específicos para o setor financeiro), Princípio de Empoderamento das Mulheres, Adesão ao "The CEO Water Mandate", Grupo de Trabalho da Moratória da Soja, Empresa Amiga da Criança;

- Compõe a carteira do Índice de Sustentabilidade Empresarial para o ano de 2012.

Fontes: Relatório Anual, 2010 e website com produtos e serviços relacionados a seguros de vida, patrimonial, saúde e automóvel; (v)

\footnotetext{
${ }^{14}$ Cargos e gêneros alterados e detalhes omitidos para assegurar confidencialidade.
} 
previdência e capitalização, com produtos e serviços em previdência complementar e de capitalização; (vi) meios de pagamento, incluindo serviços de transmissão, captura, processamento e liquidação financeira das transações em meio eletrônico; e (vii) processos de suporte operacional e consórcios.

Abaixo, algumas informações financeiras selecionadas do "CDA":

Tabela 4: Informações financeiras selecionadas do conglomerado "Carlos Drummond de Andrade":

\begin{tabular}{|l|l|l|}
\hline Em R\$ bilhões & $\mathbf{2 0 1 0}$ & $\mathbf{2 0 0 9}$ \\
\hline Receita Líquida & Cerca de 70,0 & Cerca de 55,0 \\
\hline Ativos totais & Cerca de 800,0 & Cerca de 700,0 \\
\hline Lucro Líquido & Cerca de 12,0 & Cerca de 10,0 \\
\hline Patrimônio Líquido & Cerca de 50,0 & Cerca de 35,0 \\
\hline Carteira de crédito & Cerca de 400,0 & Cerca de 350,0 \\
\hline Número de agências & Cerca de 5.000 agências & Cerca de 4.800 \\
\hline
\end{tabular}

Fonte: Relatório anual, 2010

\subsubsection{Missão e valores}

O compromisso do conglomerado "CDA" com a sustentabilidade está em sua missão que expressa o desejo do banco em promover o desenvolvimento sustentável do Brasil. Entre os valores do "CDA" são citados, entre outros, o compromisso com o desenvolvimento do país, responsabilidade socioambiental, respeito e excelência no relacionamento com o cliente, comprometimento com solidez e rentabilidade, respeito à diversidade, ética e transparência. A visão de futuro do "CDA" para o ano de 2015 inclui ser reconhecido pela sua contribuição para o desenvolvimento sustentável.

\subsubsection{Estratégia para a sustentabilidade}

O envolvimento direto e formal do banco com sustentabilidade se deu somente no início da década de 2000, fortemente influenciado pelas discussões globais de sustentabilidade (e o papel do sistema financeiro para contribuir para uma sociedade sustentável) e pela atuação da Fundação, vinculada ao banco, que atua na área social desde o final da década de 1980. 
A Fundação foi criada como o braço para o investimento social do conglomerado, com o propósito de financiar projetos que buscassem soluções para problemas sociais. O foco de atuação da Fundação é fortemente influenciado pelos temas ligados à cultura e educação. A Fundação e o banco trabalham bastante alinhados quanto a questões socioambientais, especialmente pela grande experiência adquirida pela Fundação e pelo seu grande potencial articulador com stakeholders externos.

O processo de inclusão de aspectos socioambientais na gestão do banco propriamente dito tem início da década de 2000, a partir da criação de um programa (apelidado aqui de “estratégia de sustentabilidade regional") cujo objetivo era desenvolver atividades de crédito com os princípios da sustentabilidade. A origem do programa "estratégia de sustentabilidade regional" estava na intersecção entre a área de crédito e a de responsabilidade social, a partir da constatação da importância do banco no financiamento do agronegócio brasileiro em geral e da agricultura familiar em particular. O banco tem um papel relevante como financiador da agricultura familiar no Brasil e, portanto, trabalha bastante alinhado ao governo no sentido de buscar a execução de políticas públicas para o desenvolvimento agrário. O programa foi desenhado para contribuir para o desenvolvimento do país, associando crescimento econômico à inclusão social e ao respeito ao meio ambiente. Seu propósito é atuar como um dos instrumentos das políticas públicas desenhadas pelo governo para redução de pobreza. A premissa que subsidia o envolvimento do banco com este programa é que na medida em que o banco oferece crédito para o pequeno produtor rural, contribui para a viabilização deste negócio, assegurando renda e trabalho em regiões do Brasil com grande desigualdade social. Segundo o banco, somente estão aptos a receber crédito as atividades produtivas que sejam ou tenham potencial de vir a ser financeiramente viáveis, socialmente justas e ambientalmente corretas. É a busca do triple bottom line, assegurando também que o banco não tenha prejuízo com estas operações.

Segundo uma das analistas de crédito agrícola presente em uma das entrevistas:

"Nós não queremos nos limitar ao papel de agente tradicional de crédito, mas também fomentar, articular e mobilizar agentes econômicos, políticos, sociais. Nisso o banco tem um papel importante... e também no fortalecimento do associativismo e do cooperativismo, na viabilização da agricultura familiar e dos mini e pequenos empreendedores.” (Analista Sênior de Crédito Rural) 
Este programa vem crescendo desde sua criação. Este programa, embrião e atualmente um dos principais pilares da atuação socioambiental do banco busca não apenas "dar o dinheiro", mas contribuir para o desenvolvimento do plano de negócios do tomador de crédito, acompanhando os resultados, prestando assistência técnica (contando, inclusive, com agrônomos e técnicos especializados) para o produtor rural, conforme ilustra o diálogo abaixo:

“ - Pesquisadora: Então, essa é uma pauta de desenvolvimento: levar o crédito para aqueles que não teriam acesso a crédito se não fosse por esse programa?

- Analista Sênior de Crédito Rural: Sim, mas veja que nós não oferecemos apenas o crédito. Não oferecemos um produto financeiro, oferecemos uma solução integrada - que inclui o produto financeiro, mas vai bem além, oferecendo apoio técnico, inclusive. Trabalhamos não apenas com o produtor que é nosso cliente, mas muitas vezes com a cadeia de valor inteira, para assegurar que o plano de negócios seja viável e traga retorno a todos os envolvidos. Estamos trabalhando em uma versão mais avançada do apoio técnico, para que seja um técnico sustentável."

Em suma, neste programa o papel do banco é mais amplo que apenas fornecer o crédito. $\mathrm{O}$ banco desempenha diferentes papéis: (i) de assessor, na medida em que contribui para a construção do plano de negócios associado ao uso do crédito para que os resultados se realizem em três esferas: social, financeira e ambiental; (ii) de articulador, na medida em que contribui com sua presença maciça no Brasil e seu papel como instrumento de implementação de política pública para articular com diversos atores sociais e políticos necessários para viabilizar determinadas cadeias de valores com vínculos regionais e que tenham relevância na diminuição de desigualdades sociais; (iii) assessor técnico, especialmente para o caso da agricultura familiar.

Este programa do banco atua em diversas atividades econômicas: produção agrícola (como já mencionado), artesanato, cerâmica, reciclagem, entre outros. Neste programa há também uma importante participação da Fundação. 
O início da década de 2000 marca o envolvimento formal do banco com o tema da sustentabilidade. Tradicionalmente, instituições financeiras são bastante formais e legalistas, deixando muito pouco espaço para projetos que não tenham forte amparo em suas políticas aprovadas pelo Conselho de Administração. Nesta época, o "CDA" teve aprovado pelo seu Conselho de Administração as suas "Diretrizes de Sustentabilidade"15, um conjunto de compromissos socioambientais que estabelecem as bases para atuação em sustentabilidade do banco. Foi também o ano em que foi criada a área de Responsabilidade Socioambiental.

A partir de então, o processo de gestão de sustentabilidade do banco foi sendo revisto e ampliado, para abarcar novos projetos, orientações e parcerias (mantendo o programa "estratégia de sustentabilidade regional", descrito acima, como pilar da atuação em prol da sustentabilidade do banco).

A área de Responsabilidade Socioambiental é a área que coordena o tema dentro do banco, sendo a responsável por disseminar práticas, realizar diagnósticos, fazer proposições quanto ao tema para as outras áreas do banco. As áreas de negócios (como crédito, por exemplo) estão comprometidas - por meio de seu representante no Conselho de Responsabilidade Socioambiental - com o cumprimento dos compromissos assumidos nas "Diretrizes". Assim, estas áreas negociais e comerciais vêm fazendo, de maneira gradativa, implementações de questões socioambientais em seu dia-a-dia de trabalho, sendo apoiadas pela área de Responsabilidade Socioambiental.

Um exemplo deste tipo de comportamento é a inclusão de variáveis socioambientais nos processos de análise de crédito. O banco, por ser signatário dos Princípios do Equador ${ }^{16}$ e do Protocolo Verde ${ }^{17}$ adota critérios socioambientais para estabelecimento de limites de crédito

\footnotetext{
${ }^{15}$ Nome do documento alterado para assegurar a confidencialidade.

${ }^{16}$ Acordo voluntário entre mais de 70 instituições financeiras no mundo todo que concordam em aplicar um conjunto de critérios a serem observados nos processos de determinação, avaliação e gestão de riscos socioambientais na concessão de crédito de projetos acima de US\$ 10 milhões. (EQUATOR PRINCIPLES)

${ }^{17}$ Iniciativa da Federação Brasileira de Bancos - FEBRABRAN - de 2009, o Protocolo inclui princípios e diretrizes que estimulam os bancos a oferecer linhas de financiamento que fomentem a qualidade de vida da população e o uso sustentável dos recursos naturais. Os princípios também consideraram os impactos e os custos socioambientais na gestão de ativos, na análise de risco de projetos e financiamentos, e à promoção do consumo consciente dos recursos naturais (FEBRABAN).
} 
para empresas com receita líquida superior a $\mathrm{R} \$ 50$ milhões, para projetos de investimento com valor financiado pelo banco igual ou superior a $\mathrm{R} \$ 2,5$ milhões e para os financiamentos na modalidade project finance.

O processo de análise de crédito, além das etapas tradicionais de avaliação da capacidade financeira de repagamento do empréstimo por parte do tomador, considera também riscos socioambientais. Para este processo, o cliente precisa preparar um relatório socioambiental seguindo o padrão formulado pelo banco. É a partir da análise das informações contidas neste relatório que a área de crédito avalia os riscos socioambientais. Aspectos socioambientais não têm poder de veto sobre o aceite ou não de um projeto pelo banco, mas seus laudos são enviados para o Comitê de Crédito e compõem o conjunto de informações a serem utilizados pela Comitê para a tomada de decisão (aprovar ou não o crédito e decisões quanto ao limite de crédito). Se o projeto for aprovado, a avaliação dos riscos socioambientais feita anteriormente é a base para o monitoramento do desempenho socioambiental do projeto. Monitoramento este que é realizado pela área de Responsabilidade Socioambiental, em alinhamento com a área de crédito.

A partir, principalmente, do desejo de ser reconhecido como um banco sustentável, o "CDA" decidiu priorizar aspectos relativos aos recursos hídricos como um dos principais eixos de suas ações socioambientais. Isso porque como importante financiador do agronegócio brasileiro, o banco entendeu que tinha um papel a desempenhar na melhoria da relação entre o consumo de água e o agronegócio. E que uma estratégia de sustentabilidade que estivesse fundamentada em reduzir o impacto do agronegócio sobre os recursos hídricos faria todo o sentido para um banco com importante relação econômica com o setor. Também, o banco considerou que ao concentrar a comunicação de sua estratégia de sustentabilidade em um tema importante - recursos hídricos - poderia contribuir para que fosse percebido pela sociedade como um banco "mais sustentável". Assim, em 2010, o banco direcionou grande parte de seus esforços para uma atuação estratégica socioambiental voltada para este tema, fazendo parcerias relevantes com agências do governo e com ONGs. As ações socioambientais relacionadas aos recursos hídricos estão apoiadas nas seguintes frentes de atuação: (i) apoio à melhoria da qualidade dos recursos hídricos e ampliação da cobertura vegetal, por meio da disseminação de práticas de agricultura sustentável, em regiões selecionadas de acordo com a atuação do banco; (ii) mitigação de riscos socioambientais, 
incluindo o aprimoramento de ferramentas de análise e avaliação de risco socioambiental para a área de crédito do banco; (iii) apoio ao desenvolvimento de soluções financeiras que possam viabilizar negócios sustentáveis.

Resumindo, as macros linhas de atuação do "CDA" em sustentabilidade são: (i) investimento social privado e marketing de causa; (ii) apoio ao programa "estratégia de sustentabilidade regional"; (iii) definição das estratégias de sustentabilidade do banco; (iv) interlocução com stakeholders externos quanto ao tema sustentabilidade; (v) coordenação dos esforços de comunicação da sustentabilidade, incluindo preenchimento de questionários (ISE, DJSI, Guia Exame, entre outros); (vi) articulação e apoio às áreas de negócios - como crédito, por exemplo - para que avancem na execução das "Diretrizes de Sustentabilidade"; (vii) operacionalização das ações ligadas aos recursos hídricos.

4.3.4. O processo de formulação das estratégias para a sustentabilidade e o diálogo com a formulação das demais estratégias

A arquitetura do processo de formulação das estratégias do "CDA" é bastante formal e organizada, contendo diferentes níveis. O nível maior na estrutura do processo estratégico é a definição, anual, da estratégia corporativa que representa a consolidação da direção estratégica para o banco, estabelecendo os objetivos para os próximos cinco anos (considerado longo-prazo para o banco). A definição da estratégia corporativa tem como produto o plano de investimentos do "CDA", que consolida os projetos de investimentos para os próximos cinco anos, em consonância com as estratégias corporativas. Semestralmente, as áreas preparam um plano com as metas para o semestre e o ano decorrentes dos objetivos de longo prazo estabelecidos pela estratégia corporativa. Também, semestralmente as áreas apresentam uma proposta de orçamento, com as projeções orçamentárias decorrentes das metas estabelecidas. Anualmente, as áreas apresentam suas contribuições para a formulação da estratégia para os próximos cinco anos. As informações são submetidas sempre para a área de Estratégia e, posteriormente, submetidas para a aprovação final do Conselho de Administração.

O processo de formulação de estratégias para sustentabilidade do "CDA" está plenamente alinhado ao seu processo de formulação de estratégias. Há, portanto, um processo de formulação de estratégias para sustentabilidade, compreendendo um período de cinco anos, 
seguido pelo plano de investimentos. Semestralmente, há a confecção de um plano de sustentabilidade e de um orçamento para a área onde estarão previstos os recursos para as estratégias e metas de sustentabilidade estabelecidas para aquele semestre e ano. E anualmente a área faz suas contribuições para a estratégia para o período dos próximos cinco anos.

O primeiro passo na direção de uma estratégia formal de sustentabilidade foi a criação, no início da década de 2000, das "Diretrizes de Sustentabilidade" do banco, aprovadas pelo Conselho de Administração e que estabelecem as bases para quaisquer ações ligadas à sustentabilidade. Estas "Diretrizes" foram revistas em 2008 e 2010. Quaisquer projetos socioambientais que o banco venha a desenvolver precisam estar alinhados aos compromissos estabelecidos nas "Diretrizes".

Por ser um documento basilar e que orienta toda estratégia socioambiental do banco, cabe apresentar, sinteticamente, os compromissos assumidos nas "Diretrizes". Os compromissos estão organizados em torno de três eixos: (i) fomento a negócios com foco no desenvolvimento sustentável, como o financiamento de atividades de geração de trabalho e renda e de inclusão social e de atividades econômicas com tecnologias ambientalmente adequadas; (ii) fomento à práticas administrativas e negociais com responsabilidade socioambiental, disseminando os princípios da sustentabilidade na cadeia de valor do banco e fortalecer o relacionamento com stakeholders; (iii) investimento social privado, apoiando programas relacionados à consciência e preservação ambiental, à defesa e à promoção dos direitos humanos, captando recursos para apoiar ações de desenvolvimento social.

Portanto, o processo de formulação das estratégias de sustentabilidade tem origem formal na área de Responsabilidade Socioambiental do banco e é submetido à área de Estratégia (para assegurar o alinhamento com as demais estratégias corporativas) e segue para aprovação no Conselho de Administração.

A equipe da área de Desenvolvimento Sustentável conta com uma equipe de 5 pessoas: um Diretor, um Gerente e 3 analistas seniores. A área utiliza os seguintes elementos para elaborar suas proposições estratégicas: (i) lacunas entre as práticas do banco e as "Diretrizes"; (ii) benchmarking com os outros bancos, especialmente aqueles com a atuações em relação à 
sustentabilidade consideradas mais destacadas; (iii) requerimentos dos índices de sustentabilidade, especialmente os da Bolsa de Valores de São Paulo (o ISE) e da Bolsa de Nova Iorque (o DJSI); (iv) requerimentos e avanços do guia de reporte do Global Reporting Initiative; (v) elementos obtidos das áreas de negócios, como crédito e comercial; (vi) avanços em requerimentos legais e normativas do Banco Central. 
4.3.5 Reflexões e interpretações dos dados levantados

O processo de formulação das estratégias de sustentabilidade do "CDA" é altamente formalizado e hierarquizado. As estratégias são desenhadas e revistas anualmente para os próximos cinco anos, seguindo o processo abaixo simplificado:

Figura 20: Fluxo simplificado do processo de formulação estratégica para sustentabilidade do banco empresa "CDA":

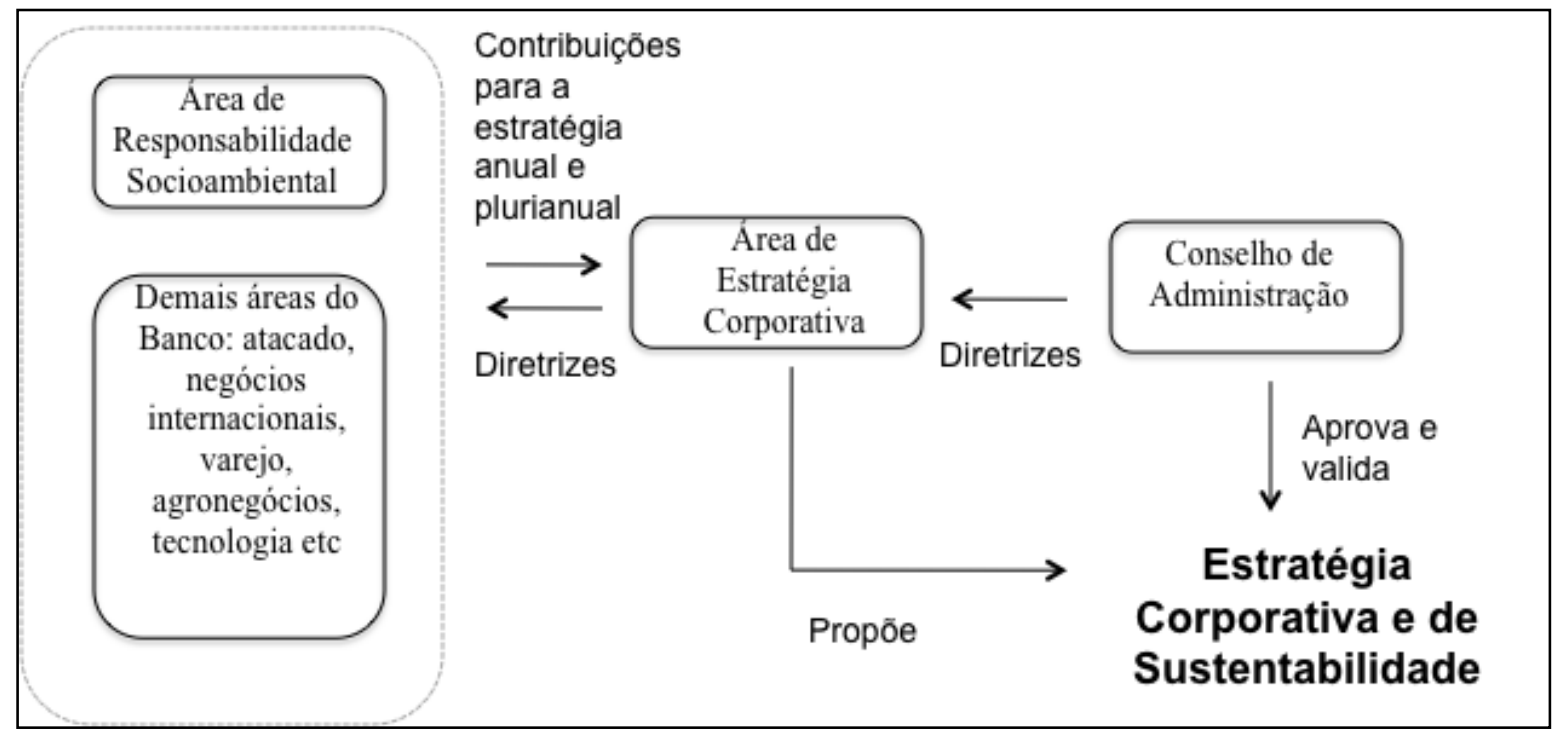

Fonte: elaboração própria a partir das entrevistas

Com relação a como as externalidades ambientais negativas são consideradas no processo de formulação estratégica socioambiental do "CDA" cabe destacar os seguintes pontos:

- Das entrevistas, notou-se que o banco se considera co-responsável pelos projetos que viabiliza, tendo este aspecto tornado-se mais evidente nas discussões sobre a responsabilidade do banco como financiador do agronegócio. Esta preocupação tem, entre suas origens, o papel do banco como importante instrumento de execução de políticas governamentais no sentido de reduzir desigualdades sociais por meio, principalmente, da viabilização da agricultura familiar. Este ponto fica evidente quando da análise do programa "estratégia de sustentabilidade regional" que tem por objetivos associar os negócios do banco (crédito, principalmente) à inclusão social. Apesar do forte caráter de instrumento de execução de políticas públicas, este programa oferece ao banco a oportunidade de ampliar seu olhar para 
os impactos (positivos e negativos) que suas atividades têm sobre a sociedade. $\mathrm{O}$ foco do programa, entretanto, é menos sobre os impactos negativos (riscos) e mais sobre os positivos, na medida em que ressalta as oportunidades de negócios que o desenvolvimento regional pode gerar para o banco;

- O olhar mais amplo sobre impactos positivos e negativos das atividades bancárias também é fomentado pela adesão ao banco de diversos compromissos voluntários (listados no Box 3), e em especial aos Princípios do Equador e Protocolo Verde, que tratam da inclusão de aspectos socioambientais nas atividades de crédito. Nestes casos, o foco é mais acentuadamente sobre os impactos negativos no sentido de sensibilizar o setor financeiro para a co-responsabilidade por ser o viabilizador de empreendimentos em uma determinada economia;

- A visão de que bancos são co-responsáveis pela viabilização de empreendimentos e que, portanto, são também responsáveis pelos impactos socioambientais que os empreendimentos por eles financiados geram vem ganhando força na sociedade. São exemplos deste tipo de ativismo:

- O trabalho do BankTrack - uma coalizão de pessoas e ONGs dedicadas a acompanhar as atividades bancárias e seus impactos sobre as comunidades e o planeta. O BankTrack publicou, em 2007 e 2010 (em 2011 uma versão somente com análise de bancos chineses), dois relatórios de pesquisa sobre as atividades bancárias e políticas de investimentos de bancos privados signatários dos Princípios do Equador e os projetos que os bancos analisados no estudo financiam e que têm altos impactos socioambientais, traçando relações entre as atividades bancárias e questões como o desmatamento da Amazônia, financiamento de atividades militares e indústria de armamentos, depleção de recursos pesqueiros, da biodiversidade, desrespeito aos direitos humanos e fundamentais do trabalhador, desrespeito aos direitos dos povos indígenas, contribuição para práticas de corrupção, entre outras. Cabe citar a relação traçada pelo BankTrack, as atividades bancárias e temas socioambientais:

"Bancos, assim como outros cidadãos corporativos, têm a obrigação de operar de maneira social e ambientalmente sustentável. Considerando o papel central que os bancos desempenham como provedores de serviços financeiros para os cidadãos, companhias e governos, os bancos podem ser agentes de mudança poderosos. Infelizmente, um conjunto de bancos comerciais e de investimentos é parte do problema e não da solução, porque tais bancos escolhem financiar atividades que geram dano ambiental, ameaçam direitos humanos, os interesses 
de comunidades locais e podem até levar a violações dos direitos humanos. Para que os bancos operem como cidadãos corporativos responsáveis, precisam integrar considerações sociais e ambientais em todas suas operações." (BANKTRACK, 2010, p.6)

- Publicação pelo Banco Central do Brasil, em Julho de 2011, da Circular N.003547que estabelece procedimentos e parâmetros relativos ao Processo Interno de Avaliação da Adequação de Capital (Icaap) - onde expressa, no inciso IV do Art $1^{\circ}$ que a "instituição deve demonstrar, no processo de avaliação e de cálculo da necessidade de capital para os riscos de que trata este artigo, como considera o risco decorrente da exposição a danos socioambientais gerados por suas atividades." (BRASIL, 2011).

- Cabe ressaltar que nesta mesma linha, o Ministério Público Federal no Pará ajuizou, em 2011, ações civis públicas contra bancos ("CDA” inclusive) por terem concedido financiamento com dinheiro público a fazendas com irregularidades ambientais e trabalhistas no Estado (MPFPA);

- Chama a atenção o fato de que o banco tem em sua estratégia para a sustentabilidade uma linha de atuação clara que sinaliza a co-responsabilidade de suas atividades de crédito na geração de impactos sociais e ambientais adversos. Entretanto, há pouco ainda em termos da co-responsabilidade de outras atividades que compõem os mercados financeiros, como mercados de capitais, monetários, cambiais etc;

- O fato de o banco ter escolhido recursos hídricos como importante aspecto de sua estratégia socioambiental reflete claramente a consideração e preocupação acerca de externalidades ambientais negativas que o agronegócio pode gerar sobre os recursos hídricos, como explicam Rodrigues e Irias (2004, p.2):

"De todos os possíveis usos da água doce, como higiene, alimentação, transporte, lazer e processos produtivos industriais, comerciais e agrícolas, os usos agrícolas são os que requerem maior volume de água. De um modo geral no mundo, cerca de $70 \%$ de toda água retirada dos rios ou do subsolo é usada para irrigação; enquanto apenas $20 \%$ se destina para usos industriais e $10 \%$ para usos residenciais. Há de se acrescentar ainda, a maior exigência relativa em termos de qualidade da água requerida para a agricultura irrigada, além deste uso ser altamente consumptivo, isto é, um uso em que grande parte ou o total da água captada não retorna aos mananciais de origem." 
- Entretanto, o banco não parece considerar espacialmente o potencial impacto acumulado de suas atividades de crédito. Considerando o escopo geográfico de atuação do banco, há espaço para melhorias se o banco passasse a analisar, como uma de suas ferramentas de gestão para a sustentabilidade, os impactos acumulados e geográficos de suas atividades de crédito. Melhor seria, se neste processo, incluísse outras atividades bancárias relacionadas aos diferentes mercados que compõem o Sistema Financeiro Nacional (capitais, monetário, cambial, entre outros).

$* * *$

A análise do caso do "CDA" aponta para a existência de relação entre o processo de formulação de estratégia de longo prazo (considerado pelo banco como cinco anos) com a noção de externalidades ambientais negativas como fio condutor deste processo. Cabe ressaltar que: (i) a escolha de recursos hídricos como um dos principais temas para sua estratégia socioambiental sugere que o banco - como importante fornecedor de crédito para o agronegócio brasileiro - tenha considerado e priorizado em seu processo de formulação estratégica o relevante impacto negativo da agricultura sobre os recursos hídricos; (ii) agricultura e recursos hídricos estão fortemente relacionados com serviços ecossistêmicos: os processos ecossistêmicos que influenciam a produção agrícola incluem retenção de solo, controle de pestes, reciclagem de nutrientes, captura de água, polinização; além disso, uso da terra afeta diretamente a disponibilidade de água e dos serviços ecossistêmicos em uma determinada região (NELSON et al, 2011; MENDOZA et al, 2011). A utilização dos conceitos de externalidades ambientais negativas e serviços ecossistêmicos parecem ter conexão com o processo de formulação das estratégias de longo prazo de sustentabilidade do "CDA".

\subsection{Análise comparativa dos casos}

Nesta seção são apresentadas análises comparativas dos casos estudados. O quadro-resumo abaixo apresenta uma síntese das características das empresas pesquisadas: 
Quadro 7: Síntese das características das empresas pesquisadas:

\begin{tabular}{|c|c|c|c|}
\hline & \multicolumn{3}{|c|}{ Empresas estudadas } \\
\hline & "Mario Quintana" & "Cecília Meireles" & $\begin{array}{c}\text { "Carlos Drummond } \\
\text { de Andrade" }\end{array}$ \\
\hline \multicolumn{4}{|c|}{ 1. Apresentação das empresas pesquisadas (Fontes: Relatórios Anuais de 2010, websites) } \\
\hline $\begin{array}{l}\text { Setor de atuação da } \\
\text { empresa pesquisada }\end{array}$ & $\begin{array}{l}\text { Holding que } \\
\text { congrega empresas de } \\
\text { um grupo empresarial } \\
\text { brasileiro com } \\
\text { atuação nos setores } \\
\text { de engenharia e } \\
\text { construção, cimentos, } \\
\text { energia, transporte, } \\
\text { calçados, indústria } \\
\text { naval, incorporação } \\
\text { imobiliária } \\
\text { siderurgia. }\end{array}$ & $\begin{array}{l}\text { Químico } \\
\text { petroquímico. }\end{array}$ & $\begin{array}{l}\text { Conglomerado } \\
\text { financeiro. Para a } \\
\text { pesquisa foi } \\
\text { considerada o banco. }\end{array}$ \\
\hline Origem do capital & Nacional, privado. & Nacional, privado. & Nacional, misto. \\
\hline Data de fundação & $\begin{array}{l}\text { Final da década de } \\
1930 .\end{array}$ & Década de 1970. & Início do século XIX. \\
\hline $\begin{array}{l}\text { Tem ações listadas } \\
\text { em bolsa de valores? }\end{array}$ & 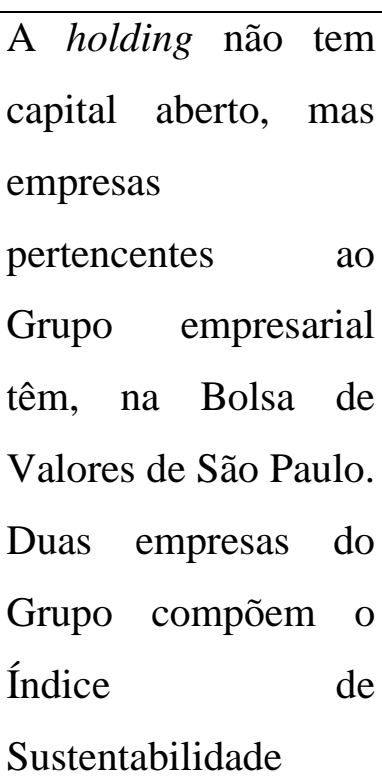 & $\begin{array}{l}\text { Sim: nas Bolsas de } \\
\text { Valores de São Paulo, } \\
\text { Nova Iorque e } \\
\text { Madrid. Na Bolsa de } \\
\text { Valores de São Paulo, } \\
\text { compõe o Índice de } \\
\text { Sustentabilidade } \\
\text { Empresarial. }\end{array}$ & $\begin{array}{l}\text { Sim, na Bolsa de } \\
\text { Valores de São Paulo. }\end{array}$ \\
\hline
\end{tabular}




\begin{tabular}{|c|c|c|c|}
\hline & $\begin{array}{l}\text { Empresarial da Bolsa } \\
\text { de Valores de São } \\
\text { Paulo. }\end{array}$ & & \\
\hline $\begin{array}{l}\text { Escopo geográfico de } \\
\text { atuação }\end{array}$ & $\begin{array}{l}\text { A holding exerce } \\
\text { gestão corporativa } \\
\text { das empresas } \\
\text { pertencentes ao } \\
\text { Grupo. As empresas } \\
\text { do Grupo, por sua } \\
\text { vez, têm produção no } \\
\text { Brasil, com destaque } \\
\text { para a Amazônia, } \\
\text { que, nos próximos } 20 \\
\text { anos, } \\
\text { responsável por } 80 \% \\
\text { da receita } \\
\text { negócios dos } \\
\text { engenharia } \\
\text { construção. } \\
\text { Internacionalmente, o } \\
\text { Grupo tem atuação na } \\
\text { Europa, Ásia, África } \\
\text { e América Latina e } \\
\text { Caribe. }\end{array}$ & $\begin{array}{l}\text { Estados Unidos e } \\
\text { Brasil. No Brasil, a } \\
\text { empresa tem unidades } \\
\text { industriais nas regiões } \\
\text { Nordeste, Sul e } \\
\text { Sudeste. }\end{array}$ & $\begin{array}{l}\text { Ampla atuação no } \\
\text { Brasil inteiro, seja por } \\
\text { meio de suas mais de } \\
5.000 \text { agências, seja } \\
\text { em função de sua } \\
\text { carteira de clientes } \\
\text { distribuídos no Brasil. } \\
\text { No exterior, o "CDA" } \\
\text { tem atuação nos } \\
\text { Estados Unidos, } \\
\text { Europa e América do } \\
\text { Sul. }\end{array}$ \\
\hline $\begin{array}{l}\text { Receita Líquida em } \\
\text { 2010: }\end{array}$ & $\begin{array}{l}\text { Cerca de } \mathrm{R} \$ 17,0 \\
\text { bilhões. }\end{array}$ & $\begin{array}{l}\text { Cerca de } \mathrm{R} \$ 28,0 \\
\text { bilhões. }\end{array}$ & $\begin{array}{l}\text { Cerca de } \mathrm{R} \$ 55 \\
\text { bilhões. }\end{array}$ \\
\hline Ativos em 2010: & $\begin{array}{l}\text { Cerca de } \mathrm{R} \$ 35 \\
\text { bilhões. }\end{array}$ & $\begin{array}{l}\text { Cerca de } \quad \mathrm{R} \$ 35 \\
\text { bilhões. }\end{array}$ & $\begin{array}{l}\text { Cerca de } \mathrm{R} \$ \quad 800 \\
\text { bilhões. }\end{array}$ \\
\hline $\begin{array}{lr}\text { Número } & \text { de } \\
\text { funcionários } & \text { em } \\
\text { 2010: } & \end{array}$ & 60.000 & 6.750 & 109.026 \\
\hline
\end{tabular}

Fonte: elaboração própria 
A seguir, são realizadas análises comparativas de certos aspectos relativos às estratégias corporativas para a sustentabilidade das empresas pesquisadas.

A. Inclusão da sustentabilidade na missão, visão e/ou valores da organização:

Das empresas pesquisadas, "Cecília Meireles" e "Carlos Drummond de Andrade" explicitamente incorporam a noção de sustentabilidade em suas missões e/ou visões. Embora a holding "Mario Quintana" não explicite a sustentabilidade em sua missão e/ou visão, expressa que suas estratégias estão assentadas sobre o lucro econômico, respeito ao meio ambiente e equidade social. Considerando-se a amplitude dos negócios do Grupo empresarial do qual a holding "Mario Quintana" faz parte, faz sentido o Grupo ter uma abordagem mais cautelosa quanto a expressar sua adesão à sustentabilidade em sua missão e/ou visão, especialmente porque algumas de suas atividades produtivas são conduzidas e serão ampliadas em biomas de alta complexidade socioambiental - como a Amazônia, por exemplo -, o que poderia levar à percepção de incongruência entre as atividades produtivas do Grupo e sua missão e/ou visão. Para o caso da empresa "Cecília Meireles" sua visão relaciona sustentabilidade aos negócios, na medida em que a empresa expressa que quer ser líder na oferta de produtos químicos sustentáveis. Fica claro neste statement que a empresa enxerga clara correlação entre sustentabilidade e negócios, posicionando-se como uma empresa que enxerga sustentabilidade como alavanca de valor. Já o "CDA" expressa que quer contribuir para o desenvolvimento sustentável e ser reconhecido por esta sua contribuição.

B. Estratégias para a sustentabilidade e reflexões sobre a incorporação de externalidades ambientais negativas nas estratégias de sustentabilidade:

Nas três empresas pesquisadas, há equipes dedicadas ao tema da sustentabilidade. Estas equipes são as responsáveis por liderar o tema dentro da organização, defender prioridades, riscos e oportunidades envolvidos em aspectos socioambientais e fazem a ponte com as demais estratégias organizacionais. Representam também o principal ponto de contato das empresas com os stakeholders envolvidos nos temas sociais e ambientais. Este aspecto pareceu de grande importância para o avanço da pauta de sustentabilidade dentro das empresas pelas seguintes razões: (i) por ter uma equipe dedicada à sustentabilidade, as 
empresas desenvolveram maior conhecimento e aprofundamento acerca dos impactos de suas atividades em questões socioambientais; (ii) estas equipes vêm desenvolvendo competências conceituais e empíricas nos temas relativos à sustentabilidade e, em alguns casos, angariando reconhecimento externo neste sentido. Membros destas equipes têm sido requisitados, com frequência, para serem palestrantes em eventos externos de sustentabilidade e não raro são reconhecidos como "experts" em sustentabilidade; (iii) favorecem, internamente, um locus para antecipação de riscos e oportunidades socioambientais, assim como podem influenciar e participar da construção de regulações que estejam na pauta do governo e da sociedade.

Observou-se nas empresas pesquisadas que a área de sustentabilidade tem natureza consultiva, tendo por principal missão disseminar conhecimento sobre questões socioambientais para outras áreas das empresas. As áreas de sustentabilidade representam o lugar dentro da empresa onde o conhecimento de aspectos socioambientais é sistematizado e disseminado para dentro da organização e quando necessário, para fora dela.

Nas empresas industriais pesquisadas, a "Mario Quintana" e a "Cecília Meireles", a sustentabilidade começou na organização pela ecoeficiência, evoluindo posteriormente para sustentabilidade mais amplo senso (e mais estratégico). Foi observado nas três empresas compromisso do Conselho de Administração com a sustentabilidade.

Foi observado que "Mario Quintana" e "Carlos Drummond de Andrade" possuem processos mais estruturados de formulação de estratégias para a sustentabilidade que a empresa "Cecília Meireles”. É provável que isso se dê pelas diferentes culturas organizacionais. A cultura de "CM" é dinâmica e atribui maior ênfase no papel das pessoas que em processos estruturados. Já para o "CDA" por ser um banco, setor fortemente regulado no Brasil, e com forte laços com o governo, processos estruturados e auditáveis de gestão fazem parte da cultura organizacional. Cabe destacar que a complexidade geográfica de atuação de "MQ" e "CDA" é maior que "CM". Particularmente para o caso de "MQ", considerando a ampla gama e complexidade dos negócios do Grupo, a estruturação de processos de gestão é fundamental.

As três organizações demonstraram algum grau de consideração de externalidades ambientais negativas em suas estratégias corporativas para a sustentabilidade. Entretanto, ficou evidente que a "CM" é, das organizações pesquisadas, a que mais explicitamente considerou suas externalidades ambientais negativas em suas estratégias para a sustentabilidade. A "CM" 
parece, realmente, ter realizado um diagnóstico mais aprofundado e com escopo mais amplo de externalidades negativas que as outras duas empresas estudadas. Entre as razões pelas quais este fenômeno acontece podem estar: (i) o perfil pessoal do gestor da área que fez sua tese de doutorado em gestão estratégica para a sustentabilidade; (ii) o fato de o setor químico já vir discutindo em nível nacional e internacional aspectos socioambientais de suas atividades como ilustrado pelas iniciativas Responsible Care e Atuação Responsável (ver estudo de caso "Cecília Meireles" para maiores detalhes), o que talvez facilite as discussões acerca de estratégias de sustentabilidade na "CM" se comparada com os setores das outras empresas pesquisadas.

A consideração das externalidades ambientais negativas na cadeia de valor esteve menos presente nas estratégias corporativas para a sustentabilidade (quando comparado com as externalidades ambientais negativas geradas pela própria organização) das três empresas. Novamente, observou-se que a "CM" foi a que considerou mais amplamente suas externalidades ambientais negativas, indo além de suas próprias operações, como evidenciado nas estratégias para gases de efeito estufa e matérias-primas renováveis. O banco também considerou em algum grau o efeito da cadeia de valor, ao considerar o impacto da agricultura sobre os recursos hídricos. Já para o caso da "MQ" a análise explícita das externalidades ambientais negativas da cadeia de valor foi muito pouco observada durante as entrevistas e na leitura de fontes secundárias.

Quanto ao escopo de consideração das externalidades ambientais negativas, chamou a atenção a pouca atenção que no geral as empresas pesquisadas atribuíram aos impactos acumulados e espaciais de suas operações e cadeias de valor correspondentes para a formulação de estratégias de sustentabilidade. Este aspecto parece mais sensível no caso da "MQ"em função da complexidade de seus negócios e dispersão geográfica; em menor grau (mas não menos importante) no caso do "CDA". Também, neste aspecto, o banco considera apenas suas atividades de crédito (e não todas as atividades bancárias) e não analisa os impactos negativos acumulados regionalmente e espacialmente dos projetos financiados. Como "CDA"é um banco com presença considerável nos diversos biomas brasileiros - em especial a Amazônia e o Cerrado - parece que a análise acumulada e espacial das externalidades ambientais negativas poderia contribuir para que a formulação de estratégias para a sustentabilidade tivesse maior aderência com os impactos efetivamente viabilizados por suas operações. A 
"CM" pareceu ser a empresa que considera o impacto ambiental negativo conjunto de suas operações e com algum grau de regionalização (como demonstra a estratégia que trata de 100\% de reciclagem de água em áreas de stress hídrico). Entretanto, como uma organização em processo de internacionalização, talvez haja espaço para ampliar a regionalização das análises e incluir análises espaciais.

Nos três casos pesquisados, a inclusão da visão dos stakeholders foi em ampla medida considerada apenas por via de fontes secundárias (artigos em revistas e estudos, relatórios públicos, entre outras). Stakeholders podem fornecer inputs relevantes quanto a externalidades positivas e negativas geradas pela cadeia de valor da organização; o não engajamento de stakeholders pode levar ao sub-dimensionamento do real impacto de uma atividade produtiva sobre a sociedade, de riscos e oportunidades socioambientais.

Nos três casos observou-se aderência aos conceitos relativos a serviços ecossistêmicos mesmo no caso do banco, que é uma empresa prestadora de serviços. Portanto, a utilização do conceito de impactos e demandas sobre serviços ecossistêmicos como um importante fio condutor da análise de externalidades ambientais negativas parece ser aplicável.

Nos três casos observou-se que o conceito de "triple bottom line" foi largamente utilizado como "o" princípio da gestão para sustentabilidade, como o principal fundamento sobre o qual a gestão de um negócio comprometido com a sustentabilidade se assenta.

C. Características do processo de formulação das estratégias para sustentabilidade e diálogo com a formulação das demais estratégias:

Observou-se que os processos de formulação das estratégias para sustentabilidade e diálogo com a formulação das demais estratégias da "CM"e de "MQ" foram mais dinâmicos que do "CDA".

$\mathrm{Na}$ “MQ”o processo tem envolvimento do Conselho de Administração, da área de sustentabilidade e dos Diretores das empresas que compõem o Grupo, tanto nas definições estratégicas da área de sustentabilidade como das demais estratégias do Grupo, assegurando, portanto o alinhamento entre elas. $\mathrm{Na}$ "CM", a área de sustentabilidade é a principal 
fomentadora de iniciativas de sustentabilidade dentro da empresa. Porém, o envolvimento das áreas de negócios é considerado condição sine-qua-non para a implantação das estratégias de sustentabilidade. As áreas de negócios da empresa são envolvidas tanto nas definições estratégicas da área de sustentabilidade como das demais estratégias da empresa assegurando, portanto o alinhamento entre elas.

O processo no "CDA" é menos dinâmico que as outras duas empresas estudadas. No banco, o processo de tomada de decisão quanto às estratégias de sustentabilidade é altamente formal e racional, baseado em estudos e análises preparadas, com antecedência, pela área de sustentabilidade que é a responsável pelo tema dentro do banco. Todas as estratégias propostas para o banco (incluindo a de sustentabilidade) são submetidas à área de Estratégia, que por sua vez, assegura o alinhamento entre elas antes de propor para aprovação de instâncias superiores.

D. Aspectos da bibliografia ligada a estratégias para sustentabilidade observados na análise dos casos:

O quadro abaixo faz uma síntese dos aspectos bibliográficos ligados a estratégias para sustentabilidade observados na análise dos casos:

Quadro 8: Síntese dos aspectos bibliográficos observados na análise dos casos

\begin{tabular}{|c|c|c|c|}
\hline $\begin{array}{c}\text { Aspectos da } \\
\text { bibliografia ligada } \\
\text { a estratégias para } \\
\text { a sustentabilidade }\end{array}$ & "Mario Quintana" & "Cecília Meireles" & $\begin{array}{c}\text { "Carlos } \\
\text { Drummond de } \\
\text { Andrade" }\end{array}$ \\
\hline $\begin{array}{l}\text { Condições } \\
\text { Sistêmicas (Robèrt, } \\
\text { 2002) }\end{array}$ & Não observado. & \begin{tabular}{lr} 
Observado & no \\
processo & de \\
formulação & de \\
estratégias & para \\
\multicolumn{2}{c}{ sustentabilidade. }
\end{tabular} & $\begin{array}{l}\text { Observado, em } \\
\text { particular } \\
\text { estratégia ligada aos } \\
\text { recursos hídricos. }\end{array}$ \\
\hline $\begin{array}{ll}\text { Subprodutos } & \\
\text { negativos } & \text { das } \\
\text { atividades } & \text { da }\end{array}$ & $\begin{array}{l}\text { Observado, } \\
\text { especialmente nas } \\
\text { estratégias }\end{array}$ & Observado. & $\begin{array}{l}\text { Observado, em } \\
\text { particular na } \\
\text { estratégia ligada aos }\end{array}$ \\
\hline
\end{tabular}




\begin{tabular}{|c|c|c|c|}
\hline $\begin{array}{l}\text { empresa (Ansoff e } \\
\text { McDonnell, 1993) }\end{array}$ & $\begin{array}{l}\text { Carbono } \\
\text { Amazônia. }\end{array}$ & & recursos hídricos \\
\hline $\begin{array}{l}\text { Valor } \\
\text { compartilhado } \\
\text { (Porter e Kramer, } \\
\text { 2006; 2011) }\end{array}$ & Não observado. & Observado. & $\begin{array}{lr}\text { Observado: } & \text { estes } \\
\text { conceitos } & \text { são } \\
\text { fortemente } & \\
\text { observados } & \text { na } \\
\text { “estratégia } & \text { de } \\
\text { sustentabilidade } & \\
\text { regional". } & \end{array}$ \\
\hline $\begin{array}{l}\text { Triple Bottom Line } \\
\text { (Elkington,1998; } \\
\text { Harris et al, 2001; } \\
\text { Brundtland, Dyllick } \\
\text { e Hockerts, 2002) }\end{array}$ & $\begin{array}{lr}\text { Observado, } & \text { em } \\
\text { particular } & \text { na } \\
\text { fundamentação da } & \text { de } \\
\text { estratégia } & \text { e } \\
\text { sustentabilidade } & \\
\text { na construção da } \\
\text { ferramenta "nível } \\
\text { de } \\
\text { sustentabilidade". }\end{array}$ & $\begin{array}{l}\text { Observados, na } \\
\text { noção de que a } \\
\text { organização precisa } \\
\text { considerar aspectos } \\
\text { sociais e ambientais } \\
-\quad \text { além dos } \\
\text { econômicos - em } \\
\text { seus processos de } \\
\text { formulação de } \\
\text { estratégias para } \\
\text { sustentabilidade }\end{array}$ & $\begin{array}{lr}\text { Observado: } & \text { estes } \\
\text { conceitos } & \text { são } \\
\text { fortemente } & \\
\text { observados } & \text { na } \\
\text { “estratégia } & \text { de } \\
\text { sustentabilidade } & \\
\text { regional". } & \end{array}$ \\
\hline $\begin{array}{l}\text { Stakeholders } \\
\text { (Savitz e Weber, } \\
\text { 2006; Freeman et } \\
\text { al, 2010) }\end{array}$ & $\begin{array}{l}\text { Observado mais na } \\
\text { fundamentação das } \\
\text { estratégias de } \\
\text { sustentabilidade que } \\
\text { nas práticas } \\
\text { relatadas. }\end{array}$ & $\begin{array}{l}\text { Observado mais na } \\
\text { fundamentação das } \\
\text { estratégias de } \\
\text { sustentabilidade que } \\
\text { nas práticas } \\
\text { relatadas. }\end{array}$ & $\begin{array}{l}\text { Observado com } \\
\text { maior ênfase nas } \\
\text { parcerias com } \\
\text { ONGs locais no } \\
\text { âmbito } \\
\text { “estratégia da } \\
\text { sustentabilidade } \\
\text { regional”. } \\
\text { Observado também } \\
\text { na fundamentação } \\
\text { das estratégias de } \\
\text { sustentabilidade. }\end{array}$ \\
\hline Inovação & Pouco observado. & Observado; & Observado. \\
\hline
\end{tabular}




\begin{tabular}{|l|l|l|}
\hline sustentabilidade & estratégias de \\
(Porter e Linde, & & sustentabilidade \\
$2000 ; \quad$ Borger e & estão fortemente \\
Kruglianskas, 2006) & assentadas em \\
& inovação. \\
\hline
\end{tabular}

Fonte: elaboração própria

Nos três casos estudados, conceitos relativos a stakeholders foram pouco observados. A inclusão dos interesses dos stakeholders no processo de formulação estratégica de sustentabilidade foi feita a partir, principalmente, de informações extraídas de dados secundários.

E. Implicações sobre a teoria: há modificações sugeridas?

Como estudos de casos não permitem generalizações, o pesquisador precisa ser cuidadoso com proposições de modificações na teoria baseadas em observações de casos específicos.

Entretanto, um aspecto é aqui sugerido para investigações futuras que possam contribuir para mudanças na teoria. Trata-se da importância de se explicitar e analisar espacialmente as externalidades geradas (positivas e negativas) por uma determinada atividade econômica. No caso brasileiro isto se torna ainda mais relevante, considerando os desafios de conservação e sociais dos diferentes biomas brasileiros e as inter-relações entre eles. A bibliografia sobre estratégias para sustentabilidade não trata explicitamente da questão espacial, mas na opinião desta pesquisadora, a análise espacial é fundamental para a formulação de estratégias para sustentabilidade que tenham aderência com as externalidades negativas geradas por um negócio. 


\section{Capítulo 5: Considerações Finais}

Paul Samuelson ${ }^{18}$ disse, a respeito de Milton Friedman ${ }^{19}$ : "neste exato momento há pessoas em todo o país que estão tentando provar que Milton Friedman estava errado. Ao mesmo tempo, alguém está tentando provar que ele estava certo. Isso é o que eu chamo de influência” (ThE DAILY WATCH) . Sem dúvida, as ideias liberais de Friedman suscitam interessantes e aquecidas discussões econômicas. E no debate acerca do envolvimento das empresas com questões de responsabilidade social corporativa, Milton Friedman é quase sempre citado pela sua ferrenha oposição ao envolvimento das empresas com temas envolvidos na chamada responsabilidade social corporativa. Mesmo sem entrar na discussão acerca de responsabilidade social corporativa - já que o tema desta tese é sustentabilidade-, vale a pena trazer à tona um pouco da discussão friedmaniana.

A razão de Friedman ser muito citado em artigos e livros que tratam de responsabilidade social corporativa e sustentabilidade é devido ao seu famoso artigo publicado no jornal The New York Times (FrIEDMAN, 1970) cujo título é "The social responsibility of business is to increase its profits". No artigo, com fortes bases conceituais, Friedman expõe resumidamente ideias que estão mais bem desenvolvidas em "Capitalismo e Liberdade" (1977) e que tratam, em última análise, da responsabilidade (inclusive legal) última dos executivos de uma empresa para com seus acionistas. No artigo, Friedman argumenta que as discussões sobre responsabilidade social são frágeis conceitualmente e apresentam pouco rigor analítico. Segue, dizendo que em um sistema baseado no livre mercado, os gestores são agentes dos proprietários da empresa e, portanto, a maior responsabilidade dos gestores é conduzir os negócios em acordo com os desejos dos acionistas e de acordo com as regras básicas da sociedade, assentados em leis e nos costumes éticos. Trata-se do contrato implícito que rege as relações entre as pessoas que têm ações ou quotas de uma empresa e as responsáveis pela gestão. Argumenta que se o contrato não for regido por estes termos, ou, em outras palavras, pela lógica da busca pela eficiência na alocação de recursos, os gerentes não saberão quais são

\footnotetext{
${ }^{18}$ (1915-2009) Professor de Economia do Massachusetts Institute of Technology, laureado com o prêmio Nobel de Economia em 1970 (aliás, ele foi o primeiro norte-americano a recebê-lo) e considerado pelo New York Times como o mais importante economista do século XX.

${ }^{19}$ (1912 -2006) Economista, professor da Universidade de Chicago e de Stanford, laureado com o prêmio Nobel em Economia em 1976.
} 
seus objetivos últimos dentro de uma empresa. E ao se dedicarem a objetivos outros que não exclusivamente relacionados à maximização da riqueza do acionista - tais como redução de pobreza, redução de poluição a níveis inferiores aos permitidos pelas leis e regulações, entre outros-, objetivos para os quais não foram treinados, não serão eficientes. Além disso, nesta busca, estarão gastando o dinheiro de outros: se suas ações resultarem em menores retornos (dos que os possíveis) para os acionistas, estarão gastando o dinheiro dos acionistas; se resultar em aumento de preços, estarão gastando o dinheiro dos consumidores; se resultar em menores salários, o dos empregados. Os resultados desta ineficiência representariam, em última análise, uma espécie de novo imposto para a sociedade, imposto por pessoas (os gestores) que não estão em cargos públicos, eleitos pela sociedade para a tarefa de criar impostos. Na mesma linha, Jensen (2010) argumenta que o afastamento da lógica da maximização de valor para o acionista para a ideia de que uma empresa precisa atender, em igual medida, aos interesses de vários stakeholders levaria os gestores a terem "vários mestres" e "como diz o velho adágio, onde há vários mestres, um acaba sendo prejudicado" (JENSEN, 2010, p.32). Tirole (2006) também traz argumentos contrários a decisões à discrição dos gestores de internalizar as externalidades geradas por uma empresa sem estarem amparadas em sólidos aparatos contratuais e legais. Se os gestores forem livres para decidirem em nome de "muitos mestres" e estas decisões prejudicarem o equilíbrio econômico-financeiro da empresa, levarão à expropriação dos recursos que pertencem aos acionistas e credores. Mas, se os gestores estiverem sendo guiados pela busca da maximização do valor da empresa, da riqueza do acionista, então não haveria conflitos na internalização destas externalidades.

Se a reflexão teórica acerca das implicações da gestão para sustentabilidade é complexa e polêmica, muitas vezes opondo stakeholder e shareholder, lucro econômico e ética, responsabilidade e irresponsabilidade, sua transposição para a prática cotidiana dos gestores não fica atrás.

Ao tamanho dos desafios socioambientais atuais - em especial o tema urgente das mudanças climáticas - se opõe a sensação de que há ainda uma grande lacuna entre discurso corporativo e prática, entre intenções e entregas reais. Seriam estas lacunas causadas pela dificuldade em conciliar shareholders com stakeholders? Ou em razão da dificuldade em entender onde as questões de sustentabilidade adicionam valor às empresas? Há muito ainda que avançar no 
entendimento destas questões; mais pesquisas são necessárias para responder a estas perguntas.

Este trabalho procurou refletir se há argumentos assentados sobre a ótica de gestão de valor para o acionista que pudessem amparar os gestores em decisões relativas à gestão para a sustentabilidade, de forma a contribuir para que as empresas possam avançar na redução destas lacunas. Ao pesquisar em campo em empresas que publicamente adotam o discurso da sustentabilidade, este estudo procurou refletir se a argumentação econômica para a sustentabilidade apresentada encontrava eco nas práticas das empresas pesquisadas. $\mathrm{O}$ resultado? Encontrou. As empresas pesquisadas são grandes, importantes para a economia brasileira. São signatárias de acordos voluntários ligados a questões socioambientais; duas delas estão presentes no Índice de Sustentabilidade Empresarial da Bolsa de Valores de São Paulo para o ano de 2012. Como síntese do trabalho empírico é possível concluir que as empresas pesquisadas foram conduzidas pela noção de minimizar as externalidades que impõem sobre a sociedade. Mas isso aconteceu quando e porque fez sentido do ponto de vista dos negócios, ou seja, porque havia intersecção entre a internalização destas externalidades e a ideia de maximização do valor da empresa, da riqueza dos acionistas. Também, de forma geral, pôde ser observada que esta intersecção ocorreu para temas que têm maior escrutínio da sociedade, o que está alinhado com o referencial teórico que abordou a importância das instituições (entre os autores citados neste trabalho estão NORTH 1991; WILLIAMSON, 2000 apud Ménard, 2005; Hoffman, 2001; Peng, 2006; Peng, Wang e Jiang, 2008) e das externalidades (entre os autores citados neste trabalho estão COASE, 1960; BUCHANAN, 1969; Mishan, 1971; Baumol e OATES, 1988; PeArCe, Turner, 1990; FAucheuX et al, 1995).

Para futuros trabalhos, sugere-se o aprofundamento em modelagem econômicas que possam contribuir para o entendimento do valor que sustentabilidade gera para as empresas, como, por exemplo, estudos que visem abordar valoração de serviços ecossistêmicos e modelagens estatísticas que possam ajudar os gestores corporativos a inferir que assuntos do mundo da sustentabilidade têm maior probabilidade de serem legislados ou internalizados (via comandoe-controle ou novos mercados). Sem dúvida, há carência de ferramentas de gestão no âmbito econômico-financeiro que estejam alinhadas com a sustentabilidade. 
Há uma belíssima passagem no romance "Um conto de duas cidades" de Dickens sobre uma conversa entre dois amigos e parceiros de trabalho. Nesta passagem, um deles, Stryver, homem bem-sucedido, questiona o outro sobre sua pouca vontade em mudar os rumos de sua vida. Confrontado, Carton, "o mais indolente e menos promissor dos homens", responde que não havia muito que podia fazer para mudar seu destino. Então, o capítulo termina com o trecho abaixo:

"Com as forças esgotadas e o deserto ao seu redor, esse homem parou quando atravessava um terraço silencioso e viu, por um instante, deitada na selvageria que tinha diante de si, uma miragem de ambição decente, abnegação e perseverança. $\mathrm{Na}$ cidade clara na qual se dava a aparição, galerias arejadas de onde os amores e as graças o observavam de cima, jardins em que os frutos da vida amadureciam, águas de esperança que brilhavam perante seus olhos. Um instante depois, acabou. Subindo até seus aposentos, que ficavam num andar alto, num amontoado de casas, ele se jogou ainda vestido na cama negligenciada e molhou seu travesseiro de lágrimas desperdiçadas. Infelizmente, infelizmente, o sol se levantou; levantou-se sobre uma imagem que não poderia ser mais triste do que a do homem de grandes habilidades e grandes sentimentos, incapaz de exercê-los sem intermediários, incapaz de cuidar de si mesmo e de ser feliz, sensível à própria ruína, mas resignado a deixá-lo corroê-lo". (DICKENS, 2010, p.119)

Embora o futuro seja desconhecido, alguns sinais apontam em que direção ele se encaminha. Sábios são aqueles que conseguem entender estes sinais, ajustando rumos e escolhas, se necessário. Os sinais no sentido da sustentabilidade são inequívocos. Além dos argumentos éticos e morais, há argumentos de negócios que indicam este caminho. As pesquisas em gestão podem contribuir imensamente para que as empresas possam exercer a plenitude de suas grandes habilidades e de grandes sentimentos, cuidando bem de si mesmas, das sociedades que as acolhem e respeitando os limites ecológicos deste planeta que nos hospeda. 


\section{Capítulo 6: Bibliografia}

ABRAMOVAY, Ricardo. Responsabilidade socioambiental: as empresas no meio ambiente, o meio ambiente nas empresas. In VEIGA, José Eli da (ORG). Economia socioambiental. São Paulo: Editora SENAC, 2009

ALDY, Joseph E.; ORSZAG, Peter R.; STIGLITZ, Joseph E. Climate change: an agenda for collective action. Prepared for the conference on "The Timing of Climate Change Policies" Pew Center on Global Climate Change, October 2001. Disponível em http://citeseerx.ist.psu.edu. Acesso em 01/05/2011

ALMEIDA, Fernando. O bom negócio da sustentabilidade. Rio de Janeiro: Nova Fronteira, 2002.

ANDERSEN, Torben Juul; SCHRODER, Peter Winther. Strategic risk management practice: how to deal effectively with major corporate exposures. United Kingdom: Cambridge University Press, 2010

ANDREWS, Kenneth. The concept of corporate strategy. 2nd Edition. EUA: Dow-Jones Irwin: 1980.

ANSOFF, Igor H.; McDONNELL, Edward J. Implantando a Administração Estratégica.

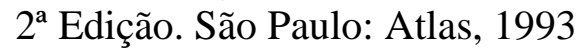

BANKTRACK. Close the gap: benchmarking credit policies of international banks. Nijmegen: $\quad$ April, $2010 . \quad$ Disponível em http://www.banktrack.org/manage/ems_files/download/close the_gap/close the gap.pdf.

Acesso 07/03/2012

BARBIERI, José Carlos. VASCONCELOS, Isabella F.G; ANDREASSI, Tales; VASCONCELOS, Flávio C. Inovação e sustentabilidade: novos modelos e proposições. In Revista de Administração de Empresas (RAE). São Paulo: v. 50, n. 2, 146-154,abr./jun. 2010

BAUMOL, William J; OATES, Wallace, E. The theory of environmental policy. 2n Edition. United States: Cambridge University Press, 1988

BORGER, Fernanda Gabriela. KRUGLIANSKAS, Isak. Corporate social responsibility and environmental and technological innovation performance: case studies of Brazilian companies. In International Journal of Technology, Policy and Management, v. 6, p. 399411, 2006.

BOYNTON, Andrew. ZMUD, Robert W. An assessment of critical success factors. In Sloan Management Review. Summer; 25, 4; 1984 
BRASIL. Banco Central do Brasil. CIRCULAR N. 003547. 07/11/2011. Disponível em https://www3.bcb.gov.br/normativo/detalharNormativo.do?method=detalharNormativo\&N=1 11046976 Acesso em 07/03/2012.

BRUE, Stanley .L. História do pensamento econômico. São Paulo: Pioneira Thomson Learning, 2005.

BUCHANAN, James M. External diseconomies, corrective taxes, and market structure. In The American Economic Review. Vol 59, No.1, pp 174-177, 1969

BUCHANAN, James M; STUBBLEBINE, Craig Wm. Externality. In Economica, New Series, Vol. 29, No. 116, pp. 371-384, Nov. 1962

CAMPOMAR, Marcos Cortez. Do uso de "estudos de caso" em pesquisas para dissertações e teses em administração. Notas \& Comunicações. Revista de Administração, São Paulo, v.26, n.3, p. 95-97, jul/set 1991.

CARROLL, Archie B.; BUCHHOLTZ, Ann K. Business \& society: ethics, sustainability and stakeholder management. Eighth Edition. USA: South-Western Cengage Learning, 2008

CHIMELI, Ariaster B.; BOYD, Roy G. Prohibition and the supply of brazilian mahogany. In Land Economics, 86, 191-208, February, 2010.

CLARK, J. Maurice. The changing basis of economic responsibility. In The Journal of Political Economy. Vol 24, No.3, pp 209-229, Mar, 1916

CLARKE, Christopher J; VARMA, Suvir. Strategic risk management: the new competitive edge. In Long Range Planning, Vol. 32, No. 4, pp. 414 to 424, 1999

COASE, Ronald H. The problem of social cost. Journal of Law and Economics, pp 1-44, 1960

CORNES, Richard; SANDLER, Todd. Theory of externalities, public goods, and club goods. $2^{\text {nd }}$ Edition. United States: Cambridge University Press, 1996

COSTANZA, Robert. D'ARGE, Ralph. GROOT, Rudolf; FARBER, Stephen. GRASSO, Monica. HANNON, Bruce. LIMBURG, Karin. NAEEM, Shahid. O'NEILL, Robert; PARUELO, Jose. RASKIN, Robert. SUTTON, Paul. VAN DEN BELT, Marjan. The value of the world's ecosystem services and natural capital. In Nature. Vol 387,1987

DAILY, Gretchen C. Introduction: what are ecosystem services. In: DAILY, Gretchen C (Ed.), Nature's services: societal dependence on natural ecosystems. Washington: Island Press, 1997.

DAILY, Gretchen C. Developing a scientific basis for managing Earth's life support systems. In Conservation Ecology, Vol 3, no. 2, 1999. Disponível em http://www.consecol.org/vol3/iss2/art14 Acesso em 01/06/2011; 
DAILY, Gretchen C; KAREIVA, Peter M.; POLASKY, Stephen; RICKETTS, Taylor H; TALLIS, Heather. Mainstreaming natural capital into decisions. In KAREIVA, Peter M; TALLIS, Heather; RICKETTS, Taylor H; DAILY, Gretchen C; POLASKY, Stephen (Editors). Natural Capital: Theory and Practice of Mapping Ecosystem Services. USA: Oxford University Press, 2011

DALY, Herman. Steady-State economics: A new paradigm. New Literary History, Papers from the Commonwealth Center for Literary and Cultural Change Vol. 24, No. 4, pp. 811-816, Autumn, 1993

DALY, Herman; FARLEY, Joshua. Ecological economics: principles and applications. United States: Island Press, 2004

DEMIL, Benôit. LECOCQ, Xavier. Business Model Evolution: In Search of Dynamic Consistency. In Long Range Planning, Vol. 43, p. 227 - 246, 2010

DICKENS, Charles. Um conto de duas cidades. São Paulo: Estação Liberdade, 2010.

DONALDSON, Thomas. PRESTON, Lee. The stakeholder theory of the corporation: concepts, evidence, and implications. In The Academy of Management Review. Vol. 20, No. 1, pp. 65-91, Jan., 1995

DYLLICK, Thomas; HOCKERTS, Kai. Beyond the business case for corporate sustainability. In Business Strategy and the Environment. Vol. 11, 130-141, 2002.

EARTH RESOURCES FOUNDATION. Disponível em http://www.earthresource.org/campaigns/capp/capp-background-info.html . Acesso em $5 / 02 / 2012$

EASTERBY-SMITH, Mark; THORPE, Richard; JACKSON, Paul R. Management research. Third Edition. Great Britain: Sage Publications, 2008

EISENHARDT, Kathleen M. Building Theories from case study research. In The Academy of Management Review, Vol. 14, No. 4., pp. 532-550. Oct. 1989

EISENHARDT, Kathleen. SULL, Donald. Strategy as simple rules. Harvard Business Review, January 2001, p 107-116

ELKINGTON, John. Sustentabilidade: Canibais com garfo e faca. São Paulo: M.Books do Brasil, 2012

Canada, Capstone. 1998

Cannibals with forks: The triple bottom line of $21^{\text {st }}$ Century business.

Towards the sustainable corporation: Win-win-win business strategies for sustainable development. In California Management Review. Vol 36. p.90, Winter 1994 
EQUATOR PRINCIPLES. Disponível em $\underline{\mathrm{http} / / / \mathrm{www} \text {.equator- }}$ principles.com/index.php/about-the-equator-principles. Acesso em 01/02/2012.

EPSTEIN, Marc J. ROY, Marie-Josée. Sustainability in action: identifying and measuring the key performance drivers. In Long Range Planning, vol 34, 585 - 604, 2001

EPSTEIN, Marc J. Making sustainability work: best practices in managing and measuring corporate social, environmental, and economic impacts. United Kingdom: Greenleaf, 2008.

EUROPEAN COMMUNITY. Disponível em http://ec.europa.eu/environment/chemicals/reach/reach_intro.htm. Acesso em 30/04/2012.

FAUCHEUX, Sylvie; MUIR, Elliot; O'CONNOR, Martin. Neoclassical natural capital theory and "weak" indicators for sustainability. Land Economics, Vol. 73, No. 4, University of Wisconsin Press : Nov, 1997, pp. 528-552

FAUCHEUX, Sylvie. NOËL, Jean- François. Economia dos recursos naturais e do meio ambiente. Lisboa: Instituto Piaget, 1995

Federação Brasileira de Bancos - FEBRABAN. Disponível em http://www.febraban.org.br/protocoloverde/. Acesso em 01/02/2012

FIGGE, Frank. HAHN, Tobias. Sustainable value added: measuring corporate contributions to sustainability beyond eco-efficiency. In Ecological Economics, 48, 2004, 173-187

FREEMAN III, A. Myrick. The Measurement of environmental and resource values: theory and methods. Second Edition. Washington: Resources for the Future Press, 2003

FREEMAN, Edward; HARRISON, Jeffrey S.; WICKS, Andrew C.; PARMAR, Bidhan L.; DE COLLE, Simone. Stakeholder theory: the state of the art. United Kingdom: Cambridge University Press, 2010

FRIEDMAN, Milton. Capitalismo e Liberdade. São Paulo: Artenova, 1977.

The social responsibility of business is to increase its profits. In The New York Times Magazine, September, 13 ${ }^{\text {th }}, 1970$.

FURTADO. João Salvador. Sustentabilidade empresarial: guia de práticas econômicas, ambientais e sociais. Salvador: NEAMA/CRA, 2005

GHEMAWAT, Pankaj. Competition and business strategy in historical perspective. In Business History Review. Harvard Business School: Spring, 2002 ,Vol. 76.

GIDDENS, Anthony. The Politics of Climate Change. UK: Polity Press, 2009

Global Reporting Inititiave - GRI. Reports Lists 2011. Disponível em http://www.globalreporting.org/ReportServices/GRIReportsList/ Acesso em 01/05/2011. 
G3.1 Guidelines 2011. Disponível em http://www.globalreporting.org/ReportingFramework/G31Guidelines/ Acesso em 01/05/2011.

GOODLAND, Robert. Sustainability: human, social, economic and environmental. In TIMMERMAN, Peter (org). Encyclopedia of Global Environmental Change, vol 5. United States: Wiley \& Sons, 2003

GUEDES, Fátima B; SEEHUSEN, Susan E. Pagamentos por serviços ambientais na Mata Atlântica: lições aprendidas e desafios. Brasília: MMA, 2011

HAGIGI, Moshe; SIVAKUMAR, Kumar. Managing diverse risks: An integrative framework. In Journal of International Management, Vol 15, pp-286-295, 2009

HAINING, Robert P. Spatial data analysis: theory and practice. United Kingdom: Cambridge University Press, 2003.

HAMILTON, Katherine. SJARDIN, Milo; MARCELLO, Thomas; XU, Gordon. Forging a frontier: state of the voluntary carbon markets 2008. Disponível em http://www.ecosystemmarketplace.com/documents/cms_documents/2008_StateofVoluntaryC arbonMarket2.pdf. Acesso em 09/06/2011

HANSON, Craig; RANGANATHAN, Janet; ICELAND, Charles; FINISDORE, John. The corporate ecosystem services review: guidelines for identifying business risks and opportunities arising from ecosystem change. Version 2.0. Washington, DC: World Resources Institute, 2012

HARDIN, Garret. The tragedy of the commons. Science Magazine. Vol. 162. no. 3859, pp.1.243 - 1.247 . December, 1968

HARRIS, Jonathan; WISE, Timothy; GALLAGHER, Kevin; GOODWIN, Neva. (Org.). $\boldsymbol{A}$ survey of sustainable development: social and economic dimensions. Washington: Island Press, 2001

HART, Stuart L; MILSTEIN, Mark B. Creating sustainable value. In Academy of Management Executive, Vol 17, No. 2, 2003

HAWKEN, Paul. LOVINS, Amory B. LOVINS, Hunter L. Natural capitalism: creating the next industrial revolution. USA, Back Bay Books, 2008.

HITT, Michael; IRELAND, R. Duane; HOSKISSON, Robert E. Strategic management: competitiveness and globalization. $4^{\text {th }}$ Edition. United States: South-Western College Publishing, 2001

HOFFMAN, Andrew J. From heresy to dogma: an institutional history of corporate envionmentalism. United States: Stanford University Press, 2001

HOURNEAUX Jr, Flávio. Relações entre as partes interessadadas (stakeholders) e os sistemas de mensuração do desempenho organizacional. São Paulo, 2010. Tese (Doutorado em Administração). Programa de Pós-Graduação em Administração, 
Departamento de Administração, Faculdade de Economia, Administração e Contabilidade da Universidade de São Paulo.

HOWARTH, Richard. Defining sustainability: an overview. Land Economics, Vol. 73, No. 4, pp. 445-447, Nov., 1997.

International Council of Chemical Associations - ICCA. Disponível em http://www.iccachem.org/en/Home/Responsible-care/. Acesso em 30/04/2012

Instituto Brasileiro do Meio Ambiente e dos Recursos Naturais Renováveis - IBAMA. Disponível em http://siscom.ibama.gov.br/monitorabiomas/. Acesso em 09/04/2012.

Instituto Brasileiro de Geografia e Estatística - IBGE. Vocabulário básico de recursos naturais e meio ambiente. $2^{\mathrm{a}}$ edição. Rio de Janeiro: IBGE, 2004. Disponível em http://www.ibge.gov.br/home/presidencia/noticias/vocabulario.pdf. Acesso em 09/04/2012.

JENSEN, Michael. Value maximization, stakeholder theory, and the corporate objective function. In Journal of Applied Corporate Finance. Volume 22, Number 1, Winter, 2010.

KORTEN. David C. When corporations rule the world. USA: Kumarian Press Inc - BerrettKoehler, 1995

KOSSOY, Alexandre; AMBROSI, Philippe. State and trends of the carbon market 2010. Washington, DC: World Bank, 2010

LAFFERTY, William M; MEADOWCROFT, James. (Ed). Implementing sustainable development. UK: Oxford University Press, 2000

LANDELL-MILLS, Natasha; PORRAS, Ina. T. Silver bullet or fools' gold? A global review of markets for forest environmental services and their impact on the poor. London: International Institute for Environment and Development, 2002

LEDERER, Markus. Regulating Carbon Markets: A plea for re-regulation not abandonment! Paper presented at the 2010 ISEE Conference, August 2010, Germany.

LÉLÉ, Sharachchandra M. Sustainable development: A critical review. World Development, Vol 19, No.6, pp 607-621, 1991.

LESSARD, Donald; LUCEA, Rafael. Embracing risk as a core competence: The case of CEMEX. Journal of International Management, Vol 15, pp 296 - 305, 2009

LOVINS, Amory; LOVINS, L. Hunter; HAWKEN, Paul . A road map for natural capitalism. In: HARVARD BUSINESS REVIEW - HBR. On Business and the environment. Boston: Harvard Business School Publishing, 2000

MANCINI, Sergio. Gestão Socioambiental. São Paulo, 2008. Tese (Doutorado em Administração). Programa de Pós-Graduação em Ciência Ambiental da Universidade de São Paulo. 
MARCONI, Marina de Andrade; LAKATOS, Eva Maria. Técnicas de pesquisa. 5a Edição. São Paulo: Editora Atlas, 2002

MARSHALL, Alfred. Principles of Economics. $8^{\text {th }}$ Edition. London: Macmillan, 1964

MARTIN, John D; PETTY, J.William; WALLACE, James S. Value-Based management with corporate social responsibility. $2^{\text {nd }}$ Edition. USA: Oxford University Press, 2009

MEADE, James E. The theory of externalities: the control of environmental pollution and other socialcCosts. Nederlands: Sitjthoff, 1973

MÉNARD, Claude. SHILEY, Mary (Eds). Handbook of new institutional economics. The Netherlands: Springer, 2005

MENDOZA, Guillermo; ENNAANAY, Driss; CONTE, Marc; TODD, Michael; FREYBERG, David; WOLNY, Stacie; HAY, Lauren; WHITE, Sue; NELSON, Erik; SOLORZANO, Luis. Water supply as an ecosystem service for hydropower and irrigation. In KAREIVA, Peter M; TALLIS, Heather; RICKETTS, Taylor H; DAILY, Gretchen C; POLASKY, Stephen (Editors). Natural capital: theory and practice of mapping ecosystem services. USA: Oxford University Press, 2011

Millennium Ecosystem Assessment - MEA. Ecosystems and human well-being: synthesis. Island Press, 2005: Washington, DC. Disponível em http://www.maweb.org/en/About.aspx. Acesso em 01/07/2011

Ministério de Desenvolvimento Social e Combate à Fome - MDS. Parceria entre governo federal e catadores de papel visa gerar trabalho e renda. Disponível em http://www.mds.gov.br/noticias/parceria-entre-governo-federal-e-catadores-de-papel-visagerar-trabalho-e-renda-1. Acesso em 29/02/2012.

Ministério Público Federal - Procuradoria da República no Pará - MPFPA. http://www.prpa.mpf.gov.br/. Acesso em 07/03/2012.

MINTZBERG, Henry. Patterns in strategy formation. Management Science, Vol.24, No.9, p 934-948, May, 1978

. Crafting strategy. Harvard Business Review, July, 1987, p. 66 - 75

Tracking strategies: toward a general theory of strategy formation. Great Britain: Oxford University Press, 2007

MINTZBERG, Henry. AHLSTRAND, Bruce. LAMPEL, Joseph. Safári de estratégia: um roteiro pela selva do planejamento estratégico. Porto Alegre: Bookman, 2000

MISHAN, E.J. The postwar literature on externalities: an interpretative essay. Journal of Economic Literature, vol.9, no.1, p1-28, Mar 1971

MOTTA, Ronaldo S. Desafios ambientais da economia brasileira. Instituto de Pesquisa Econômica Aplicada - IPEA. Rio de Janeiro, 1997. Disponível em http://www.ipea.gov.br Acesso em 21/09/2010. 
MYERS, Michael D. Qualitative research in business \& management. Great Britain: Sage Publishing, 2009.

NELLEMANN, C., CORCORAN, E. (Editors). Dead planet, living planet - biodiversity and ecosystem restoration for sustainable development: a rapid response assessment. United Nations Environment $\quad$ Programme, 2010. $\quad$ Disponível em http://www.unep.org/themes/biodiversity/ Acesso em 14/06/2011

NELSON, Erik; WOOD, Stanley; KOO, Jawoo; POLASKY, Stephen. Provisioning and regulatory ecosystem service values in agriculture. In In KAREIVA, Peter M; TALLIS, Heather; RICKETTS, Taylor H; DAILY, Gretchen C; POLASKY, Stephen (Editors). Natural capital: theory and practice of mapping ecosystem services. USA: Oxford University Press, 2011

NELSON, Robert H. Sustainability, efficiency, and God: economic values and the sustainability debate. Annual Review of Ecology and Systematics, Vol. 26, 1995, pp. 135154.

NORTH, Douglass. Institutions. In The Journal of Economic Perspectives. Vol.5, N.1, pp 97-112, Winter, 1991

NORTH, Douglass. Institutions and the performance of economies over time. In MÉNARD, Claude; SHIRLEY, Mary (org.) Handbook of New Institutional Economics. Germany: Springer, 2008

O GLOBO. "Confira quais capitais brasileiras restringem uso de sacolas plásticas. Lei sobre o tema entrou em vigor em Belo Horizonte na segunda (18). Treze capitais já têm legislação aprovada; outras nove, apenas projetos." Reportagem de 19/04/2011. Disponível em http://g1.globo.com/brasil/noticia/2011/04/confira-quais-capitais-brasileiras-ja-restringemuso-de-sacolas-plasticas.html. Acesso em 25/02/2011

OLSON, Mancur. The logic of collective action: public goods and theory of groups. United States: Harvard University Press. 20a edição, 2002

OSTROM, Elinor. Governing the commons: the evolution of institutions for collective action. $22^{\text {nd }}$ Edition. USA: Cambridge University Press, 2008

OSTROM, Elinor; BURGER, Joanna; FIELD,Christopher; NORGAARD, Richard; POLICANSKY, David. Revisiting the commons: local lessons, global challenges. In Science Magazine, New Series, Vol. 284, No. 5412, pp. 278-282, Apr. 9, 1999

OSTROM, Elinor. GARDNER, Roy. WALKER, James. Rules, games, and common-pool resources. United States: University of Michigan Press, 1994

PAGIOLA, Stefano. Payments for environmental services: an introduction. Washington: World Bank, 2006 
PARRIS, Thomas; KATES, Robert W. Characterizing and measuring sustainable development. In Annual Review Environmental Resources. Vol 28 (559-586), 2003. Disponível em http://www. arjournals.annualreviews.org. Acesso em 19/03/2008

PEARCE, David W. The limits of cost-benefit analysis as a guide to environmental policy. KYKLOS (International Review for Social Sciences). Vol.29, Fasc.1, 97-112, 1976.

PEARCE, David W; TURNER, Kerry R. Economics of natural resources and the environment. Great Britain: The Johns Hopkins University Press, 1990

PENG, Mike W. Global strategy. United States: Thomson, 2006

PENG, Mike W; WANG, Denis YL; JIANG, Yi. An institution-based view of international business strategy: a focus on emerging economies. In Journal of International Business Studies. Vol.39 (920-936), 2008

PIGOU, Arthur Cecil. Economics of welfare. $4^{\text {th }}$ Edition. London: Macmillan, 1932

PLASTIVIDA. Instituto Sócio-Ambiental do Plástico. Disponível em http://www.plastivida.org.br/2009/Projetos_SacolasPlasticas.aspx. Acesso em 12/08/2012.

PORRIT, Jonathan. Capitalism as if the world matters. UK: Earthscan, 2007

PORTER, Michael. Competitive strategy. New York: Free Press, 1980

PORTER, Michael E; LINDE, Claas van der. Green and competitive: ending the stalemate. In: Harvard Business Review. On Business and the environment. Boston: Harvard Business School Publishing, 2000

PORTER, Michael E; KRAMER, Mark R. Strategy and society. The link between competitive advantage and corporate social responsibility. In Harvard Business Review. Dezembro, 2006

PORTER, Michael E; KRAMER, Mark R. The big idea: creating shared value. In Harvard Business Review. Jan-Feb, 2011

PRAHALAD, Coimbatore. K. A riqueza na base da pirâmide: Como erradicar a pobreza com o lucro. Porto Alegre: Bookman, 2005

RANDALL, Alan. Market solutions to externality problems: theory and practice. American Journal of Agricultural Economics. Vol. 53, No. 5, Proceedings Issue, pp. 867, Dec.1971

ROBÈRT, Karl-Henrik. The Natural Step. A história de uma revolução silenciosa. São Paulo: Cultrix, 2002

RODRIGUES, Geraldo Stachetti; IRIAS, Luiz José. Considerações sobre os impactos ambientais da agricultura irrigada. Circular Técnica- EMBRAPA. Jaguariúna, São Paulo: Julho, 2004. Disponível em http://www.agencia.cnptia.embrapa.br/recursos/circular 7IDcKH03Ez46o.pdf Acesso em 07/03/2012 
SACHS, Ignacy. Em busca de novas estratégias de desenvolvimento. In Estudos Avançados. [online]. 1995, vol.9, n.25, pp. 29-63. ISSN 0103-4014. Disponível em http://www.scielo.br/pdf/ea/v9n25/v9n25a04.pdf. Acesso em 27/05/2011

SACO É UM SACO. Disponível em http://www.sacoeumsaco.gov.br/. Acesso em 25/02/2011.

SAMPIERI, Roberto Hernandez; COLLADO, Carlos Fernández; LUCIO, Pilar Baptista. Metodologia de pesquisa. $3^{\text {a }}$ Edição. São Paulo: McGraw-Hill, 2006

SAMUELSON, Paul A. Economics: an introductory analysis. United States: McGraw-Hill, 1948

SAUNDERS, Mark; LEWIS, Philip; THORNHILL, Adrian. Research methods for business students. Harlow: Pearson Education Limited, Fifth Edition, 2009

SAVITZ, Andrew W; WEBER, Karl. The triple bottom line: how today's best run companies are achieving economic, social and environmental success - and how you can too. United States : John Wiley \& Sons, 2006

SCHMANDT, Jurgen; WARD, Calvin Herbert (Org). Sustainable development: the challenge of transition. Cambridge: Cambridge University Press, 2000.

SEIFFERT, Mari Elizabete Bernardini. Mercado de carbono e protocolo de Quioto. São Paulo; Editora Atlas, 2009

SEVÁ FILHO, Oswaldo (org). Tenotã-Mõ. São Paulo: International Rivers, 2005. Disponível em: http://www.socioambiental.org/banco_imagens/pdfs/tenotamo.pdf. Acesso em 01/02/2012.

SOARES, Fabio Rubens. DEMAJOROVIC, Jacques. O programa Atuação Responsável no Brasil. II Workshop Gestão Integrada: Risco e Sustentabilidade. São Paulo, Maio de 2006. Senac.

http://www1.sp.senac.br/hotsites/arquivos_materias/II_workshop/O_programa_Atuacao_Resp onsavel_no_Brasil.pdf. Acesso em 30/04/2012.

SOUZA, Carlos Augusto Vaz de. Análise de acidentes de trabalho em indústrias de processo contínuo: estudo de caso na refinaria de Duque de Caxias, RJ. Rio de Janeiro, 2000. Dissertação de mestrado. Escola Nacional de Saúde Pública.

STEGER, Ulrich; IONESCU-SOMERS, Aileen; SALZMANN, Oliver. The economic foundations of corporate sustainability. In Corporate Governance. Vol.7, no.2 (162-177), 2007

STERN, Nicholas. The economics of climate change: The Stern review, 2007 Disponível em: $\quad$ http://webarchive.nationalarchives.gov.uk/+/http://www.hmtreasury.gov.uk/independent_reviews/stern_review_economics_climate_change/stern_review report.cfm. Acesso em 03/01/2011 
. The economics of climate change. Proceedings of the Richard T. Ely

Lecture. In American Economic Review: Papers \& Proceedings, 98:2, 1-37, 2008

STIGLITZ, Joseph E. The new development economics. In World Development, Vol 14, No2, pp 257-265, 1986

A new agenda for global warming. In STIGLITZ, Joseph E; EDLIN, Aaron S.; DeLONG, Bradford J. (Eds). The Economists' Voice: top economists take on today's problems. USA: Columbia University Press, 2008

SVENDSEN, Ann. The stakeholder strategy: profiting from collaborative business relationships. United States: Berrett-Koehler Publishers, 1998

TEECE, David J. Business models, business strategy and innovation. In Long-Range Planning, 43, 172-194, 2010

The Daily Watch. Disponível em http://thedailyhatch.org/2012/04/11/listing-of-transcriptsand-videos-of-free-to-choose-episode-3-anatomy-of-a-crisis-on-www-thedailyhatch-org-2/.

Acesso em 30/04/2012.

The Economics of Ecosystems and Biodiversity - TEEB. A Economia dos ecossistemas e da biodiversidade: integrando a economia da natureza. Uma síntese da abordagem, conclusões e $\begin{array}{lllll}\text { recomendações do (2010). } & \text { Disponível }\end{array}$ http://www.teebweb.org/Portals/25/TEEB\%20Synthesis/TEEB_Sintese-

Portugues_web[1].pdf Acesso em 01/07/2011.

TIROLE, Jean. The theory of corporate finance. United States: Princeton University Press, 2006

United Nations Environmental Programme - UNEP, 2011. Towards a green economy: pathways to sustainable development and poverty eradication - A synthesis for policy makers. Disponível em www.unep.org/greeneconomy. Acesso em 08/06/2011

United Nations Framework Convention on Climate Change - UNFCCC, 2009. Clean Development Mechanism. Annual Report. Disponível em HTTP:// cdm.unfccc.int. Acesso em 30/05/2011

VARIAN, Hal.R. Microeconomia: princípios básicos. Rio de Janeiro: Elsevier, 2006.

VEIGA, Fernando; GAVALDÃO, Marina. Status das iniciativas e projetos de Pagamentos por Serviços Ambientais (PSA) no Brasil. The Nature Conservancy. Abril, 2010.

VEIGA, José Eli da (ORG). Economia socioambiental. São Paulo: Editora SENAC, 2009

VEIGA, José Eli da. Sustentabilidade: A legitimação de um novo valor. São Paulo: Editora SENAC, 2010

VERGARA, Sylvia C. Projetos e relatórios de pesquisa em Administração. 4. ed. São Paulo: Atlas, 2003. 
YIN, Robert K. Estudo de caso: planejamento e métodos. $3^{\text {a }}$ edição. Porto Alegre: Bookman, 2005.

WORLD BANK, 2010. World Development Report 2010: Development and Climate Change. Disponível em http://www.worldbank.org/wdr. Acesso em 15/03/2011

World Business Council for Sustainable Development - WBCSD. Disponível em http://www.wbcsd.org. Acesso em 01/02/2012

World Business Council for Sustainable Development - WBCSD. Vision 2050: The new agenda for business. $\quad$ Disponível em http://www.wbcsd.org/templates/TemplateWBCSD5/layout.asp?type=p\&MenuId=MTYxNg \&doOpen=1\&ClickMenu=LeftMenu. Acesso em 19/04/2011.

WUNDER, Sven; ALBÁN, Montserrat. Decentralized payment for environmental services: the cases of Pimampiro and PROFAFOR in Ecuador. In Ecological Economics, Vol 65 (685698), 2007 


\section{Apêndice I}

\section{Protocolo de Estudo de Caso: Roteiro semi-estruturado de entrevista}

1. Caracterização do entrevistado (nome, cargo e função que ocupa);

2. Estrutura da área de sustentabilidade;

3. Qual o entendimento da organização sobre sustentabilidade e como esta questão está inserida nos processos formais de formulação estratégica? Como as estratégias da organização dialogam com as estratégias de sustentabilidade?

4. Quais as principais informações relacionadas a aspectos socioambientais são utilizadas no processo de formulação estratégica? A organização considera apenas "dentro dos portões do negócio" ou tem a visão da cadeia de valor?

5. A organização utiliza como insumo para seu processo de formulação estratégica uma análise formal dos impactos ambientais de sua cadeia de valor, desde a extração primária ao fim da vida do produto ou serviço? (Inside-Out, Poter e Kramer, 2006)

6. A organização utiliza como insumo para seu processo de formulação estratégica uma análise formal do impacto ambiental de suas atividades sobre recursos comuns, como água, biodiversidade, serviços ecossistêmicos?

7. Quais aspectos não financeiros a organização entende que podem fazer a diferença no estabelecimento de vantagens comparativas da organização no longo prazo?

8. A empresa considera formalmente em seu processo de formulação estratégica para a sustentabilidade avanços regulatórios, criação de novos mercados ou outras formas de internalização de externalidades? 


\section{Apêndice II - Definições de conceitos relevantes}

- Análise espacial: "Espacial" significa que os dados analisados têm referências geográficas, de forma que seja possível identificar geograficamente em um mapa, onde os eventos ocorrem. "Análise espacial" tem suas raízes na geografia e é um termo mais largamente utilizado nas literaturas referentes a Sistemas de Informações Geográficas (GIS, na sigla em inglês) e a Ciência de Informação Geográfica (GISc, na sigla em inglês). Resumidamente, a análise espacial possui três elementos: (i) modelagem cartográfica, onde os dados observados são representados em mapas; (ii) modelagem matemática, onde os resultados do modelo dependem da forma de interação espacial entre os objetos modelados e suas posições e relacionamentos geográficos; e (iii) técnicas estatísticas que permitam realizar análises e inferências sobre o comportamento espacial dos dados em análise. (HAINING, 2003; p. 4-6)

- Bioma: "Conjunto de vida (vegetal e animal) definida pelo agrupamento de tipos de vegetação contíguos e identificáveis em escala regional, com condições geoclimáticas similares e história compartilhada de mudanças, resultando em uma diversidade biológica própria."(IBGE, p.49). Segundo o IBAMA, são os biomas brasileiros: Amazônia, Caatinga, Cerrado, Mata Atlântica, Pampa, Pantanal. (IBAMA)

- Capacidade de carga da Terra: Traduz a capacidade de recuperação do ambiente natural visà-vis o impacto (população x afluência x tecnologia), taxa de depleção de recursos renováveis e não-renováveis e acúmulo de resíduos perigosos no ambiente. O ponto de equilíbrio é rompido quando o crescimento da população, a depleção dos recursos ou acúmulo de resíduos causam o rompimento de qualquer uma das funções de sustentação da vida na Terra (FURTADO, 2005).

- Common-Pool Resource (CPR): O termo Common-Pool Resources (CPRs) trata de recursos naturais ou construídos pelo homem que têm dois atributos: (i) é difícil excluir indivíduos dos benefícios gerados pelo recurso; e (ii) o consumo do recurso por um indivíduo diminui a oferta para outros. Estes dois atributos criam potenciais dilemas em que pessoas buscando seus interesses de curto-prazo produzem resultados de longo prazo insatisfatórios para todos (OSTROM, GARDNER, WALKER, 1994; CORNES, SANDLER, 1996). 
- Desenvolvimento sustentável: Desenvolvimento sustentável é o processo pelo qual nos movemos no sentido da sustentabilidade (PORRIT, 2007). Os aspectos essenciais para o desenvolvimento sustentável são: (i) econômico - um sistema economicamente sustentável deve ser capaz de produzir produtos e serviços continuamente, manter níveis de dívidas governamental e externa gerenciáveis, evitar desequilíbrios setoriais que prejudiquem a produção industrial e agrícola; (ii) ambiental - um sistema ambientalmente sustentável mantém uma base estável de recursos, evitando a super exploração de recursos renováveis ou a degeneração ambiental e o uso de recursos não renováveis somente na extensão em que investimentos forem feitos em substitutos adequados; inclui manutenção da biodiversidade, estabilidade da atmosfera e outras funções ecossistêmicas não comumente classificadas como recursos econômicos; (iii) social - um sistema socialmente sustentável obtém justiça na distribuição de renda e oportunidades, provisão adequada de serviços sociais, incluindo saúde e educação, tratamento igualitário dos gêneros e participação e assunção de responsabilidades por parte do governo (HARRIS et al, 2001).

- Ecoeficiência: O conceito de ecoeficiência une economia e meio-ambiente: a "ecoeficiência é atingida quando há entrega de produtos e serviços competitivos em termos de preço que satisfaçam as necessidades humanas e contribuam para a melhor qualidade de vida, ao mesmo tempo em que progressivamente reduzem os impactos ecológicos e a intensidade de consumo de recursos ao longo do ciclo de vida a um nível, pelo menos, alinhado com a capacidade de carga da Terra" (WBCSD).

- Externalidade: "Uma economia externa (ou deseconomia) é um evento que confere benefícios apreciáveis ou impõe danos apreciáveis em alguma pessoa ou pessoas que não foram partes que consentiram no processo decisório que resultou, direta ou indiretamente, no evento em questão" (MEADE, 1973, p.15)

- Fatores Críticos de Sucesso (FCS): São aqueles aspectos que devem ir bem para assegurar o sucesso para um gestor ou uma organização, e, portanto, representam aquelas áreas da gestão ou da organização que precisam receber atenção especial e contínua para que possam gerar alto desempenho (BOYTON, ZMUD, 1984).

- Instituições: Instituições são as regras escritas e não escritas, normas, restrições que os seres humanos criam para reduzir a incerteza e controlar o ambiente em que vivem. Nestas, estão 
incluídos (i) as regras e acordos escritos que regulam relações contratuais e governança corporativa; (ii) constituições, leis e regras que governam políticas, governo, finanças e sociedade em um senso mais amplo; e (iii) códigos de conduta, normas de comportamento e crenças não escritos (NORTH 1991; WILLIAMSON, 2000, apud MÉNARD, 2005).

- Materialidade: Uma informação em um relatório deve cobrir tópicos e indicadores que reflitam os impactos significativos econômicos, sociais e ambientais ou que possam influenciar substancialmente as avaliações e decisões de stakeholders (GRI, G3.1 2011).

- Serviços Ecossistêmicos: Serviços ecossistêmicos são as condições e os processos pelos quais os ecossistemas naturais e as espécies que os compõem sustentam a vida humana (DAILY, 1997).

- Stakeholders: São quaisquer grupos que podem afetar e serem afetados pela realização dos propósitos de uma organização (FREEMAN et al,2010).

- Sustentabilidade: (i) Sustentabilidade é a capacidade de continuidade no futuro de longoprazo. Sustentabilidade é o objetivo último, o destino desejado para a espécie humana e para qualquer outra espécie. (PORRIT, 2007). O termo sustentabilidade será expresso, ao longo deste estudo, como o fim último do processo de desenvolvimento sustentável. Portanto, envolve as questões de cunho econômico, social e ambiental apresentadas no conceito de desenvolvimento sustentável. (ii) Também, o termo "sustentabilidade" é expresso ao longo deste trabalho como a aplicação para o mundo corporativo dos conceitos de “desenvolvimento sustentável”.

- Tragédia dos Comuns: A "tragédia dos comuns" trata de um tipo particular de externalidade: o caso de recursos de uso comum, onde a racionalidade da escolha individual resulta em colapso coletivo ou irracionalidade coletiva (HARDIN, 1968). 


\section{Apêndice III - O Global Reporting Initiative (GRI)}

O GRI é um think- tank baseado na Holanda que tem por missão prover orientação e framework para o reporte da sustentabilidade por organizações do mundo todo. A premissa que baseia o trabalho do GRI é uma economia global sustentável onde as organizações gerenciam seu desempenho e seus impactos nas dimensões econômica, social e ambiental de maneira responsável e os reportam de maneira transparente (GRI).

Desde sua fundação em 1997 - uma iniciativa conjunta da Coalition for Environmentally Responsible Economies (CERES) e do Programa das Nações Unidas para o Meio Ambiente (PNUMA)-, foram desenvolvidos frameworks e procedimentos para o processo de elaboração dos relatórios de sustentabilidade, cujo objetivo é descrever os impactos econômicos, ambientais e sociais (Triple Bottom Line) de uma organização. O relatório, segundo o GRI, deve oferecer uma descrição equilibrada e ponderada do desempenho de sustentabilidade da organização relatora, incluindo informações tanto positivas como negativas. Relatórios de sustentabilidade representam uma maneira prática de medir, divulgar e prestar contas para stakeholders internos e externos do desempenho organizacional visando o desenvolvimento sustentável (HOURNEAUX JR, 2010; MANCINI, 2008 ).

Os padrões GRI para reporte da sustentabilidade têm recebido cada vez mais atenção das empresas do mundo todo. A adoção das diretrizes GRI para reporte da sustentabilidade cresceu vertiginosamente: de 11 relatórios seguindo o padrão GRI em 1999 para 1.847 em 2010. O crescimento maior se deu por parte de empresas da Europa - eram cinco reportando em 1999 e 829 em 2010. Mas chama atenção o crescimento do número de empresas relatoras oriundas da Ásia, que subiu de uma em 1999 para 369 em 2010. As empresas brasileiras também cresceram na adoção dos padrões GRI: de uma em 2000 (a Natura), para 133 em 2010; padrão similar seguiu a América Latina: de uma em 2001 para 130 em 2010.

O gráfico a seguir apresenta o número total de organizações que adotam o padrão GRI no período de 1999 a 2010. Na sequência, a tabela 5 apresenta a distribuição dos países e regiões das empresas relatoras. 
Gráfico 1: Número total de organizações que adotam o padrão GRI para reporte da sustentabilidade, por ano:

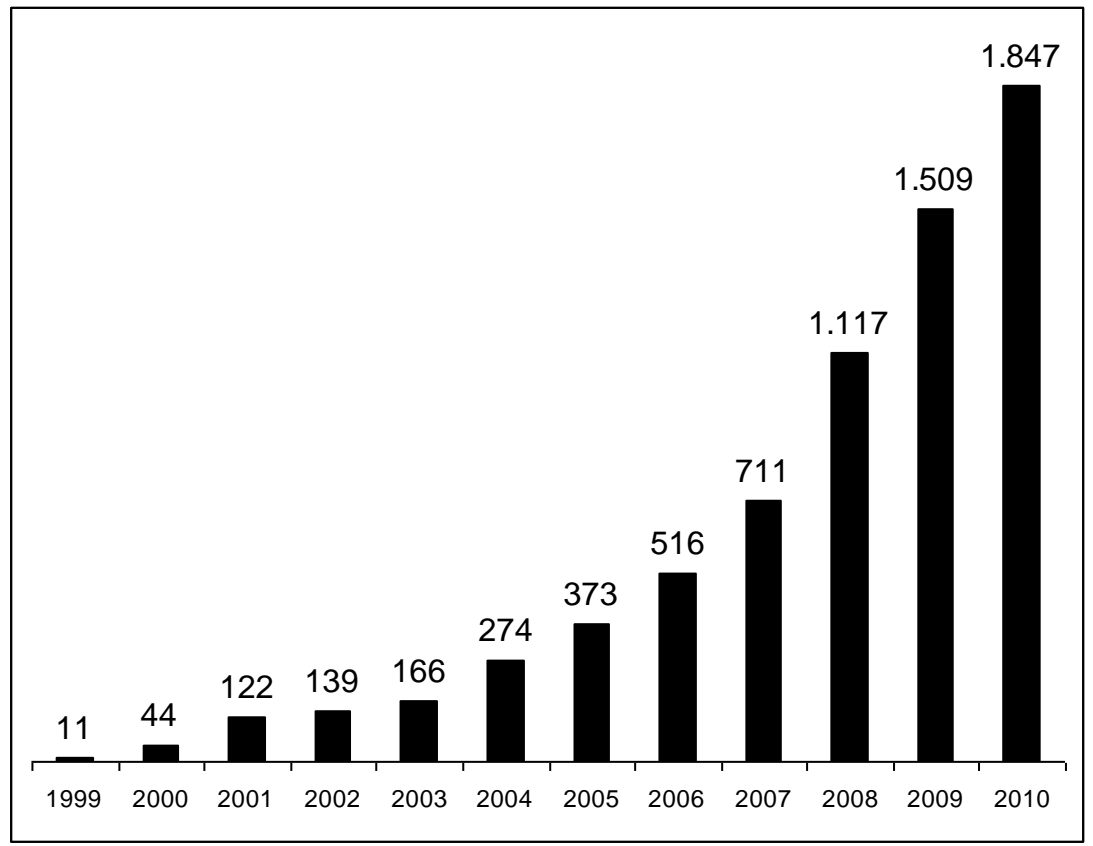

Fonte: Autora, baseado em GRI Reports list,2011

Tabela 5: Países/regiões das empresas relatoras, por ano:

\begin{tabular}{|c|r|r|r|r|r|r|r|r|}
\hline $\begin{array}{c}\text { Países / } \\
\text { Regiões }\end{array}$ & Europa & $\begin{array}{l}\text { América do } \\
\text { Norte }\end{array}$ & Brasil & $\begin{array}{c}\text { América } \\
\text { Latina (- } \\
\text { Brasil) }\end{array}$ & África & Ásia & Oceania & Total \\
\hline 1999 & 5 & 5 & 0 & 0 & 0 & 1 & 0 & 11 \\
\hline 2000 & 21 & 10 & 1 & 0 & 3 & 7 & 2 & 44 \\
\hline 2001 & 59 & 25 & 1 & 1 & 1 & 26 & 9 & 122 \\
\hline 2002 & 53 & 31 & 5 & 4 & 8 & 26 & 12 & 139 \\
\hline 2003 & 79 & 31 & 4 & 1 & 19 & 22 & 10 & 166 \\
\hline 2004 & 147 & 47 & 7 & 4 & 22 & 33 & 14 & 274 \\
\hline 2005 & 219 & 50 & 12 & 8 & 23 & 38 & 23 & 373 \\
\hline 2006 & 273 & 69 & 18 & 35 & 25 & 56 & 40 & 516 \\
\hline 2007 & 371 & 96 & 38 & 43 & 24 & 91 & 48 & 711 \\
\hline 2008 & 512 & 154 & 72 & 70 & 51 & 187 & 71 & 1.117 \\
\hline 2009 & 687 & 182 & 81 & 109 & 54 & 306 & 90 & 1.509 \\
\hline 2010 & 829 & 248 & 133 & 130 & 56 & 369 & 82 & 1.847 \\
\hline $\begin{array}{c}\text { Crescimento } \\
\mathbf{2 0 1 0} / \mathbf{1 9 9 9}\end{array}$ & $\mathbf{8 2 4}$ & $\mathbf{2 4 3}$ & $\mathbf{1 3 3}$ & $\mathbf{1 3 0}$ & $\mathbf{5 6}$ & $\mathbf{3 6 8}$ & $\mathbf{8 2}$ & $\mathbf{1 . 8 3 6}$ \\
\hline Fin & & & & & & & & \\
\hline
\end{tabular}

Fonte: Autora, baseado em GRI Reports list,2011

O GRI adota os seguintes princípios para a definição do conteúdo que deve estar presente no relatório de sustentabilidade: (i) materialidade, implicando que o relatório deve cobrir tópicos e indicadores que reflitam os impactos econômicos, sociais e ambientais significativos da 
organização e que possam influenciar as avaliações e decisões por parte dos stakeholders; (ii) inclusão de stakeholders, implicando que a organização deve identificar quem são seus stakeholders e explicitar no relatório como respondeu às expectativas e interesses de seus stakeholders; (iii) contexto de sustentabilidade, implicando que a organização deve reportar seu desempenho em um amplo contexto de sustentabilidade; e (iv) completude, implicando que o reporte de sustentabilidade da organização deve ser suficiente para refletir os impactos sociais, ambientais e econômicos materiais da organização e que possa permitir a seus stakeholders avaliar o desempenho da organização no período reportado (GRI, G3.1 Guidelines, 2011).

O GRI também define os princípios para assegurar a qualidade do relatório: (i) equilíbrio; ou seja, o relatório deve refletir aspectos positivos e negativos do desempenho da organização nos aspectos sociais, ambientais e econômicos; (ii) comparabilidade, implicando que as informações reportadas pela organização devem permitir a análise, por parte dos stakeholders, da evolução do desempenho ao longo do tempo; (iii) exatidão na informação reportada; (iv) periodicidade no reporte das informações, ou seja, que o reporte aconteça de maneira periódica; (v) clareza nas informações reportadas para que sejam compreensíveis aos stakeholders; (vi) segurança no processo de preparação do relatório, nas etapas de coleta de dados, organização das informações, compilação e análises de tal forma que possa ser avaliado por terceiros (GRI, G3.1 Guidelines, 2011).

De maneira geral, as diretrizes do GRI indicam que o reporte da sustentabilidade deve abordar três grandes categorias de informações: (i) o perfil da organização, que são informações que estabelecem o contexto geral para a compreensão do desempenho organizacional, tais como sua estratégia, perfil e governança; (ii) a forma de gestão da organização, que descreve o modo como a organização trata determinado conjunto de temas; e (iii) os indicadores de desempenho, informações comparáveis ao longo do tempo sobre o desempenho econômico, ambiental e social da organização (GRI, G3.1 Guidelines,2011).

Assim, a organização deve reportar informações que favoreçam a análise de seu perfil, incluindo informações detalhadas sobre a estratégia organizacional, compromisso da alta administração com a sustentabilidade, governança da organização e da sustentabilidade, escopo e fronteiras do relatório, descrição do processo de análise de materialidade e engajamento de stakeholders. Os indicadores de desempenho são padronizados e devem 
respeitar o protocolo do GRI para sua preparação. São divididos em seis categorias: indicadores ambientais, de direitos humanos, práticas de trabalho e trabalho decente, sociedade, responsabilidade pelo produto e econômico. Cada categoria contém indicadores essenciais, que deveriam ser respondidos por todas as organizações e os indicadores adicionais que representam práticas emergentes e que podem ser de interesse de alguns grupos de stakeholders, mas não a todos (GRI, G3.1 Guidelines).

O quadro abaixo sintetiza os princípios e a divulgação padrão, segundo as diretrizes GRI:

Quadro 9: Síntese dos princípios e da divulgação padrão, segundo as diretrizes GRI

\begin{tabular}{|c|c|}
\hline Categoria & Descrição \\
\hline \multicolumn{2}{|c|}{ Princípios para definição do conteúdo do relatório } \\
\hline Materialidade & $\begin{array}{l}\text { Relatório deve descrever os impactos } \\
\text { econômicos, sociais e ambientais } \\
\text { significativos da organização. }\end{array}$ \\
\hline Inclusão de Stakeholders & $\begin{array}{l}\text { Relatório deve identificar os principais } \\
\text { stakeholders da organização suas } \\
\text { expectativas e interesses foram } \\
\text { considerados. }\end{array}$ \\
\hline Contexto de Sustentabilidade & $\begin{array}{l}\text { Reporte deve considerar o amplo contexto } \\
\text { de sustentabilidade. }\end{array}$ \\
\hline Completude & $\begin{array}{l}\text { O reporte deve ser completo, refletindo os } \\
\text { impactos sociais, ambientais e } \\
\text { econômicos materiais da organização. }\end{array}$ \\
\hline \multicolumn{2}{|c|}{ Princípios para assegurar a qualidade do relatório } \\
\hline Equilíbrio & $\begin{array}{l}\text { Equilíbrio entre aspectos positivos e } \\
\text { negativos do desempenho organizacional. }\end{array}$ \\
\hline Comparabilidade & $\begin{array}{l}\text { Desempenho deve ser comparável ao } \\
\text { longo de um período de tempo. }\end{array}$ \\
\hline Exatidão & Informações exatas. \\
\hline Periodicidade & $\begin{array}{l}\text { Periodicidade no reporte de } \\
\text { sustentabilidade. }\end{array}$ \\
\hline
\end{tabular}




\begin{tabular}{|c|c|}
\hline Clareza & $\begin{array}{l}\text { Reporte deve ser claro e compreensível } \\
\text { para os stakeholders. }\end{array}$ \\
\hline Segurança & $\begin{array}{l}\text { Processo de coleta e sistematização de } \\
\text { dados seguros para permitir auditoria de } \\
\text { terceira parte. }\end{array}$ \\
\hline \multicolumn{2}{|c|}{ Divulgação padrão } \\
\hline \multicolumn{2}{|l|}{ 1. Perfil da Organização } \\
\hline Estratégia e análise & $\begin{array}{l}\text { Apresentação das estratégias de curto, } \\
\text { médio e longo prazos, visão sobre os } \\
\text { principais desafios competitivos } \\
\text { enfrentados pela organização, descrição } \\
\text { de principais impactos e metas. }\end{array}$ \\
\hline Perfil organizacional & $\begin{array}{l}\text { Dados da organização, como nome, } \\
\text { estrutura organizacional, localização das } \\
\text { áreas produtivas, estrutura acionária, } \\
\text { número de funcionários, fábricas, valor } \\
\text { dos ativos, entre outras informações. }\end{array}$ \\
\hline Parâmetros do relatório & $\begin{array}{l}\text { Período coberto pelo reporte, processos } \\
\text { utilizados para definição do escopo e } \\
\text { fronteiras do relatório- tais como, análise } \\
\text { de materialidade, identificação e diálogo } \\
\text { com stakeholders-, mudanças } \\
\text { significativas em relação ao último } \\
\text { relatório publicado, se o relatório será } \\
\text { auditado. }\end{array}$ \\
\hline $\begin{array}{l}\text { Governança, compromissos e } \\
\text { engajamento }\end{array}$ & $\begin{array}{l}\text { Estrutura de governança da organização, } \\
\text { mecanismos para participação de } \\
\text { stakeholders e acionistas minoritários, } \\
\text { missão e visão da organização, } \\
\text { compromissos voluntários, lista de grupos } \\
\text { de stakeholders engajados pela } \\
\text { organização. }\end{array}$ \\
\hline
\end{tabular}




\begin{tabular}{|c|c|}
\hline Ambientais & $\begin{array}{l}\text { Indicadores referentes a uso de materiais, } \\
\text { consumo de energia e água, impacto sobre } \\
\text { a biodiversidade, emissões, efluentes e } \\
\text { resíduos, impactos ambientais de produtos } \\
\text { e serviços, cumprimento de leis, impacto } \\
\text { ambiental da logística de transportes e } \\
\text { investimentos realizados em proteção } \\
\text { ambiental. }\end{array}$ \\
\hline Direitos Humanos & $\begin{array}{l}\text { Indicadores referentes à inclusão de } \\
\text { cláusulas de direitos humanos em } \\
\text { contratos com fornecedores, políticas de } \\
\text { não-discriminação, liberdade de } \\
\text { associação sindical, políticas para evitar } \\
\text { incidentes de trabalho infantil e trabalho } \\
\text { escravo na cadeia de suprimentos, práticas } \\
\text { de segurança, direitos indígenas, gestão de } \\
\text { aspectos ligados a direitos humanos na } \\
\text { gestão da organização. }\end{array}$ \\
\hline Práticas de trabalho e trabalho decente & $\begin{array}{l}\text { Indicadores referentes à gestão da força de } \\
\text { trabalho, gestão ocupacional, saúde e } \\
\text { segurança do trabalhador, treinamento e } \\
\text { educação, diversidade e oportunidades } \\
\text { iguais de trabalho, equanimidade na } \\
\text { remuneração. }\end{array}$ \\
\hline Sociedade & $\begin{array}{l}\text { Indicadores referentes a gestão da relação } \\
\text { da organização com as comunidades } \\
\text { próximas às operações, práticas de } \\
\text { prevenção à corrupção e ao } \\
\text { comportamento anti-competitivo, } \\
\text { engajamento em definição de políticas } \\
\text { públicas e cumprimento da legislação } \\
\text { aplicável. }\end{array}$ \\
\hline Responsabilidade pelo produto & Indicadores referentes à saúde e segurança \\
\hline
\end{tabular}




\begin{tabular}{|l|l|}
\hline & $\begin{array}{l}\text { do consumidor, etiquetagem do produto, } \\
\text { comunicação e marketing, privacidade do } \\
\text { consumidor cumprimento da legislação } \\
\text { aplicável. }\end{array}$ \\
\hline Econômicos & $\begin{array}{l}\text { Indicadores referentes ao desempenho } \\
\text { econômico-financeiro, presença de } \\
\text { mercado e impactos econômicos indiretos. }\end{array}$ \\
\hline
\end{tabular}

Fonte: Autora, baseado em GRI G3.1 Guidelines,. 2011

O GRI prevê critérios para definição dos níveis de aplicação das diretrizes GRI nos relatórios de sustentabilidade, assim como sugerem que o nível de aplicação das diretrizes seja informado no relatório. Os níveis de aplicação variam de uma escala de C (o menor nível), $\mathrm{C}+, \mathrm{B}, \mathrm{B}+, \mathrm{A}, \mathrm{A}+$ (o maior nível). O sinal de + indica que o relatório foi verificado por terceira parte. A categorização em um dos níveis de aplicação deve seguir os padrões estabelecidos pelo GRI e depende do nível de divulgação e aderência aos indicadores essenciais e adicionais, assim aderência aos suplementos setoriais (GRI, G3.1 Guidelines, 2011).

Por meio dos princípios da materialidade e do contexto de sustentabilidade, as diretrizes GRI incorporam, ao menos teoricamente, o conceito de externalidades negativas na gestão estratégica para a sustentabilidade. 